$$
\text { Portsmouth }
$$


This report has been reproduced directly from the best available copy.

Available to DOE and DOE contractors from the Otfice of Scientific and Technical Information, P.O. Box 62, Oak Ridge, TN 37831; prices available from (615) 576-8401, FTS 626-8401.

Available to the public from the National Technical Information Service, U.S. Department of Commerce, 5285 Port Royal Rd., Springfield, VA 22161.

This report was prepared as an account of work sponsored by an agency of the United States Government. Neither the United States Government nor any agency thereof, nor any of their employees, makes any warranty, express or implied, or assumes any legal liability or responsibility for the accuracy, completeness, or usefulness of any information, apparatus, product, or procens disclosed, or represents that its use would not infringe privately owned rights. Reference herein to any specific commercial product, process, or service by trade name, trademark, mariufacturer, or otherwise, does not necessarily constitute or imply its endorsement, recommendation, or favoring by the United States Government or any agency thereot. The views and opinions of authors expressed herein do not necessarily state or reflect those of the United States Government or any agency thereof. 


\title{
PORTSMOUTH GASEOUS DIFFUSION PLANT ENVIRONMENTAL REPORT FOR 1990
}

\author{
Project director \\ F. C. Kornegay \\ Project coordinator \\ D. C. West \\ Technical coordinator \\ R. L. Grant \\ Coordinating editor \\ Deborah Counce-Brown
}

Date Published: September 1991

Prepared by

Environmental, Safety, and Health Compliance and Environmental Management Staff

MARTIN MARIETTA ENERGY SYSTEMS, INC.

P.O. Box 2008

Oak Ridge, Tennessee 37831 and the

Environmental Control Department

Portsmouth Gaseous Diffusion Plant

MARTIN MARIETTA ENERGY SYSTEMS, INC.

P.O. Box 628

Piketon, Ohio 45661

for the

U.S. DEPARTMENT OF ENERGY

under contract DE-AC05-84OR21400 and DE-AC05-76OR00001 


\section{EXECUTIVE SUMMARY}

This calendar year 1990 annual report on environmental surveillance of the U.S. Department of Energy's (DOE's) Portsmouth Gaseous Diffusion Plant (PORTS) and its environs consists of two parts: the summary, discussion, and conclusions (Part 1) and the data presentation (Part 2).

\section{SCOPE AND PURPOSE}

The objectives of this report are as follows:

- report 1990 monitoring data for the installation and its environs that may have been affected by operations on the plant site,

- provide reasonably detailed information about the plant site and plant operations,

- provide detailed information on input and assumptions used in all calculations,

- provide trend analyses (where appropriate) to indicate increases and decreases in environmental impact, and

- provide general information on plant quality assurance.

\section{MONITORING NETWORKS}

Environmental-monitoring systems at PORTS include emission-monitoring networks for air and surface water discharges; waste sampling and characterization; and ambient-sampling networks for air, surface water, groundwater, drinking water, vegetation (cattle forage), food crops, fish, soil, creek and river sediments, and direct (gamma) radiation levels.

Emission- and waste-monitoring networks include the following:

- a network of 9 continuous vent samplers on the major radionuclide and fluoride emission sources,
- continuous opacity monitors on the PORTS coal-fired steam boilers and regular laboratory analysis of delivered coal,

- a network of 14 sampling locations for plant discharges to locai surface waters plus 6 sampling locations for internal discharges (i.e., processes that discharge to other monitored discharges),

- a routine sampling program for identifying and characterizing waste streanis generated by plant operations, an:i

- an ongoing sampling program for stored wastes and sludges to characterize these materials in support of Resource Conservation and Recovery Act (RCRA) and Comprehensive Environmental Response, Compensation and Liability Act activities.

Ambient-sampling networks are significantly more extensive and are generally organized into three groups:

- On-site stations located in the PORTS area. This grcup includes locations near Perimeter Road, an area of limited public access, and locations within the plant's secure area, which is accessible only to employees and authorized visitors.

- Property-line stations located on or near the DOE property line (the closest unrestricted public approach to the planit).

- Off-site stations located at some distance from the PORTS site. These stations are located up to $16 \mathrm{~km}$ (10 miles) from the site and are sometimes divided into off-site and remote or background groups.

The individual (media-specific) networks include the following: 
- 17 air-sampling stations ( 6 on-site, 8 property-line, and 3 off-site).

- 14 "off-site" surface-water-sampling locations [6 downstream of the plant outfalls permitted under the National Pollutant Discharge Elimination System (NPDES); 4 upstream of plant outfalls; and 4 background samples about $16 \mathrm{~km}$ (10 miles) out in the 4 cardinal directions (north, east, south, west)]. Two of the downstream locations are within the DOE site and are only nominally off-site.

- 274 groundwater-monitoring wells in 9 on-site groundwater-monitoring systems ( 9 waste disposal areas), the majority of which support groundwater quality assessments at the 4 RCRA sites at PORTS.

- 11 off-site drinking-water-sampling locations (local residents with well, cistem, or natural spring water supplies who have allowed PORTS personnel to collect water samples for analysis).

- 18 samples of various local food crops.

- 35 vegetation-sampling locations consisting of grass typical of local cattle forage [ 12 property-line, 6 "ncar" off-site (within $5 \mathrm{~km}$ ), and 13 "far" off-site (5 to $16 \mathrm{~km}$ ), and 4 background].

- 22 fish samples from 11 locations (8 on-site, and 3 "off-site" locations).

- 51 soil-sampling locations [16 on-site, 12 property-line, 6 "near" off-site, 13 "far" off-site, and 4 background locations about $16 \mathrm{~km}$ (10 miles) in each of the cardinal directions. Property-line and off-site soil-sampling locations are collocated with the vegctation-sampling locations.]

- 17 stream-sediment-sampling locations $[5$ on-site, 8 "off-site," and 4 background locations about $16 \mathrm{~km}$ (10 miles) out in the 4 cardinal directions].

- 33 gamma-radiation-monitoring locations (10 on-site, 8 property-line, and 15 off-sitc).

In 1990, approximately 100,000 measurements were taken in air, groundwater, streams, drinking water, food crops, grasses, fish, refuse, sewage, soil, sediment, and sludge. The results of these analyses and investigations are presented in this report, and the major findings are summarized in the following subsections.

\section{AIRBORNE DISCHARGES AND AIR MONITORING}

Many point and nonpoint sources in the plant are permitted by the state of Ohio and EPA for the relcase of pollutants into the atmosphere. These pollutants include standard industrial emissions such as smoke (fly ash), sulfur dioxide $\left(\mathrm{SO}_{2}\right)$, gaseous fluorides, gasoline and diesel fuel vapors, cleaning solvent vapors, and process coolants (chlorofluorocarbons), as well as small amounts of radionuclides. Airborne radionuclides are the main source of radiation dose to the public from plant operations.

A total of $0.095 \mathrm{Ci}$ of radionuclides was released to the air in $1990,52 \%$ of which was ${ }^{99} \mathrm{Tc}$ (a weak beta emitter) and $44 \%$ of which was uranium isotopes (all alpha emitters). The remainder (4\%) comprised the various short-lived uranium daughters (beta emitters). The trend in airborne radionuclide emissions is shown in Fig. 1.

Of the nonradiological air pollutants released from PORTS, smoke and $\mathrm{SO}_{2}$ from the coal-fired steam plant are the most significant. In 1990 the X-600 Steam Plant achieved $99.94 \%$ compliance for opacity and $83 \%$ compliance for $\mathrm{SO}_{2}$ with its Ohio Environmental Protection Agency (OEPA) permit limits. The cause of the low compliance with the $\mathrm{SO}_{2}$ limit was a retroactive change in permit limits. In April 1990, OEPA notified PORTS that the permit limits for $\mathrm{X}-600 \mathrm{SO}_{2}$ emissions had been lowered and that the new limits were effective as of November 1989. At the time this notice was received, the new $\mathrm{SO}_{2}$ limits had already been exceeded for January and March 1990. Since receipt of the new permit requirements, $\mathrm{SO}_{2}$ emissions have been maintained at a $100 \%$ compliance level.

\section{EXTERNAL GAMMA RADIATION}

The whole-body external gamma exposure at and around PORTS is given in Fig. 2. These values include gamma radiation attributable to PORTS opcrations, natural terrestrial gamma radiation, and natural cosmic radiation. It is not possible to separate these contributions because the average off-site gamma levels are higher than the average on-site and property-line levels. This is because of higher concentrations of natural radionuclides in the shale and sandstone hills surrounding PORTS than in the 


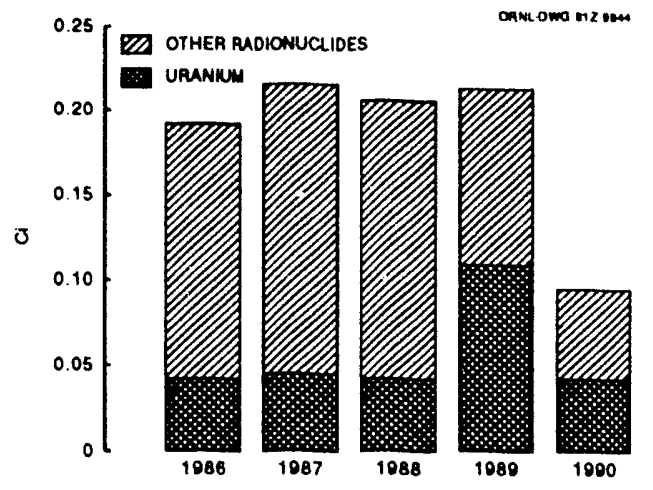

Fig. 1. Radionuclides discharged to the air at PORTS, 1986-1990.

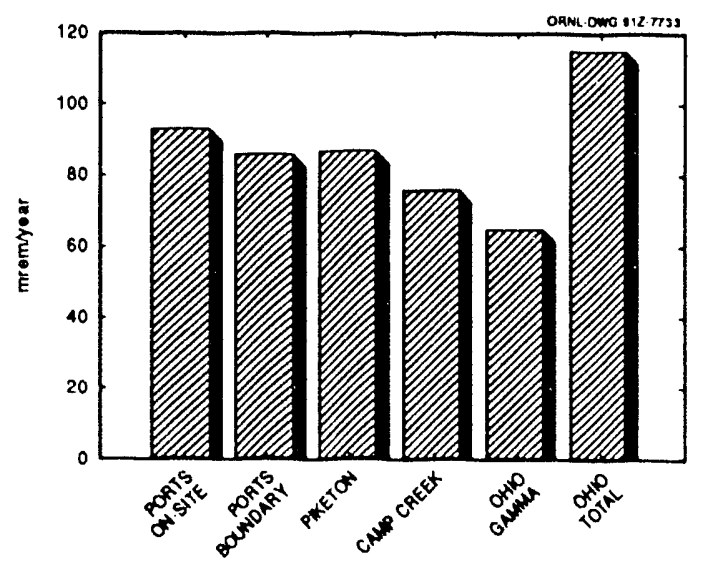

Fig 2. Whole-body external gamma exposures at and around PORTS.

clays and silts directly under the plant. None of the radiation levels found is significantly different from the average radiation levels throughout Ohio.

\section{WATERBORNE DISCHARGES AND SURFACE WATER MONITORING}

All plant-site liquid effluents are regulated by the plant's NPDES permit. They either discharge to surface streams that pass through the reservation or are piped directly to the Scioto River. Overall plant-wide NPDES compliance was $98 \%$ for $C Y$ 1990. Figure 3 is a 5 -year trend chart on NPDES compliance at PORTS.

Radiological analyses are performed at all NPDES sampling locations and at other routine water-sampling locations that can contribute to assessing the impact of plant discharges on the receiving stream through upstream and downstream measurements. Data and graphs presented in this report show that the effects of 1990 discharges on the receiving streams have been minimal and that they are comparable to past annual discharges. Discharges to Little Beaver Creek appear to have only slight impact on radioactivity levels downstream, primarily because X-705 operations were redirected to new treatment facilities and to outfall 004 and the Scioto River. Plant discharges appear to have no noticeable effect on radioactivity levels in Big Run Creek or the Scioto River. Figure 4 shows the 5-year trend in waterborne emissions at PORTS.

A number of pollution abatement projects and activities were initiated or completed in 1990. They include continued optimization efforts at the biodenitrification facility; optimization of the new X-705 waste treatment facility (NPDES 605); conversion of a portion of the recirculating cooling water system from chromates to phosphates; continued NPDES permitting negotiations with EPA; initiation of improvement projects for the X-621 coal pile treatment facility (NPDES 602), the south holding pond (NPDES 002), and the chromate treatment facility (NPDES 004); and continued algac control at Gas Centrifuge Enrichment Plant ponds (NPDES G001 and G002). The most significant activity in 1990 was the formation of an NPDES task team and the appointment of a full-time NPDES program manager (this activity was initiated in CY 1989 and continued through CY 1990).

\section{GROUNDWATER MONITORING}

The groundwater-monitoring program is directed toward assessment monitoring at four RCRA land disposal units, detection monitoring at the sanitary landfill, and off-site residental monitoring. The RCRA monitoring programs are based upon the results of a groundwater quality assessment of the RCRA Units (Geraghty \& Miller, Inc. 1989). The 


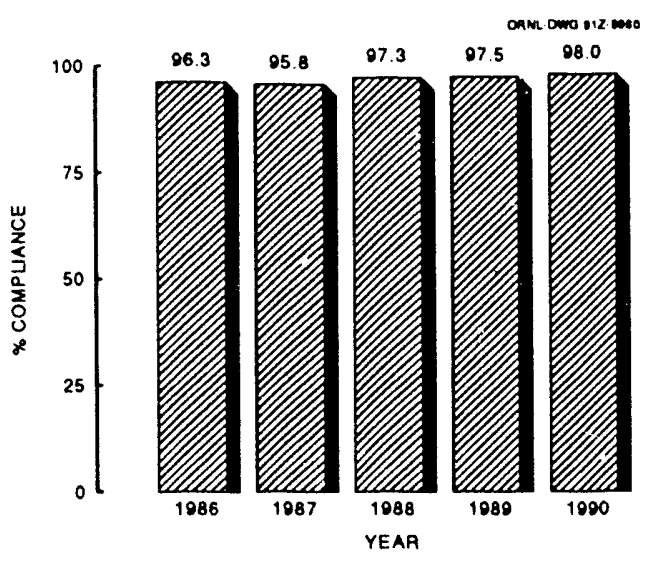

Fig. 3. NPDES compllance at PORTS, 1986-1990.

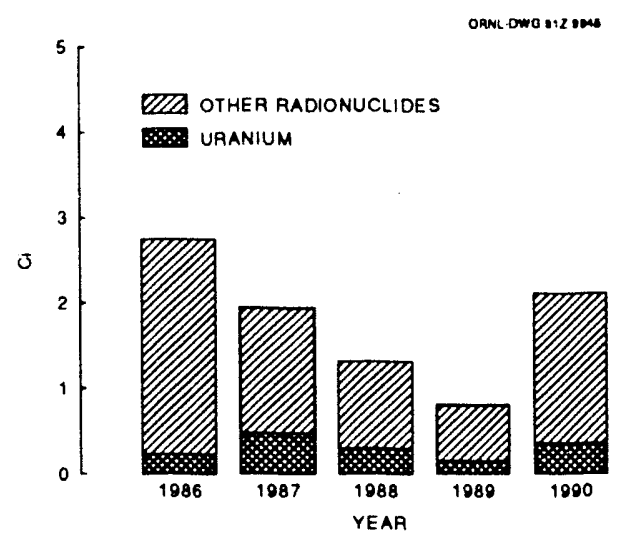

Fig. 4. Waterborne emissions at PORTS, 1986-1990.

monitoring program uses wells completed in the Gallia sand and the Berea sandstone that are monitored quarterly for an approved analytes list. This plan includes 21 wells at X-701B Water Treatment Facility, 18 wells at X-749 Contaminated Materials Disposal Facility, 11 wells at X-231B Land Treatment Area, and 12 wells at X-616 Chromium Sludge Surface Impoundments. In addition, surface water monitoring was conducted at Little Beaver Creck, Big Run Creek, and the unnamed southwest drainage ditch. The local creeks are points of discharge for groundwater.

Detection monitoring is currently under way at the X-735 Sanitary Landfill. To comply with change in Solid Waste Regulations, six groundwatermonitoring wells were installed, using RCRA protocols, around the perimeter of the X-735 landfill.

The Off-site Residential Groundwater Monitoring Program was continued at PORTS in 1990. A review of the Off-Site Monitoring Program by a DOE/Martin Marietta Energy Systems, Inc., committee determined that historical and recent data indicate that plant operations at PORTS have had no adverse chemical or radiological effects on residential drinking water supplies in the area.

\section{OTHER MONITORING}

\section{Biological monitoring}

Analyses of fish showed no significant pattern of contamination. Samples of food crops showed no contamination with radionuclides. Technetium concentrations were all lower than the lower analytical confidence level. Results from grass samples collected and analyzed for radionuclide contamination showed no significant contamination; alpha activities were at or below normal background levels. Uranium and technetium were all below the lower analytical confidence level.

\section{Soil and sediment sampling}

Soil samples are taken in tandem with the grass samples to support estimations of uptake rates of radionuclides by vegetation. In 1990, two sampling locations (one of them a background location located 10 miles upwind of the plant) showed slight technetium contamination. The grass samples from these locations did not show detectable technetium, however, even though technetium bioaccumulates strongly in plants. Nor did soil and grass samples taken from between these two locations and the plant show any sign of contamination. PORTS continues to monitor these locations to see whether the contamination persists, but it has not been determined how contamination could have migrated to these locations. Sediment samples are taken from local surface waters to check for any buildup of waterborne radionuclides. As in the past, results showed minor 
and highly variable radionuclide concentrations in sediments downstream of one plant outfall, diminishing to no detectable contamination in Scioto River sediments. There is no indication of any ongoing buildup of radionuclides at any single point.

\section{RADIATION DOSES TO THE PUBLIC}

The maximum 50-year committed effective dose equivalent (EDE) to any individual from PORTS activities during 1990 is $0.06 \mathrm{mrem}$. A comparison of maximum EDEs due to airborne emissions over the last 5 years is shown in Fig. 5. A comparison of maximum EDEs due to waterborne emissions over 5 years is shown in Fig. 6 . None of the doses resulting from PORTS operations is significant to public health. The maximum 50-year committed EDE to any individual during 1990 from airborne emissions was only $0.06 \mathrm{mrem} / \mathrm{year}$, much lower than the NESHAP standard of $10 \mathrm{mrem} / \mathrm{year}$ of plant operation.

The calculated EDE from drinking water and eating fish from the Scioto River throughout 1990 was only $0.002 \mathrm{mrem} / \mathrm{year}$. This dose is below the EPA public drinking water limit of $4 \mathrm{mrem} / \mathrm{year}$ that applies to beta-emitting radionuclides in a public water supply and the DOE limit of $100 \mathrm{mrem} / \mathrm{year}$ for all exposure pathways (waterborne plus airborne). No public water supply and no known private water supply draws from the Scioto River, and only occasional sports fishing takes place on the river downstream of PORTS. Consequently, the calculated dose is hypothetical and should be very conservative. Also, this hypothetical maximum waterborne dose is located on the opposite side of the plant (southwest) from the maximum airborne dose (east-northeast); this makes it unlikely that one individual could be exposed to both doses.

The population dose (collective EDE) from airborne radionuclides was 0.008 person- $r \mathrm{em} /$ year to the nearest community and 0.4 person-rem/year to the total population within $80 \mathrm{~km}$ (50 miles) of the plant. No waterborne population dose was calculated because the population exposed is essentially zero.

\section{CHEMICAL RELFASES}

In compliance with the Superfund Amendments and Reauthorization Act (SARA), storage and releases of hazardous chemicals have been reported to

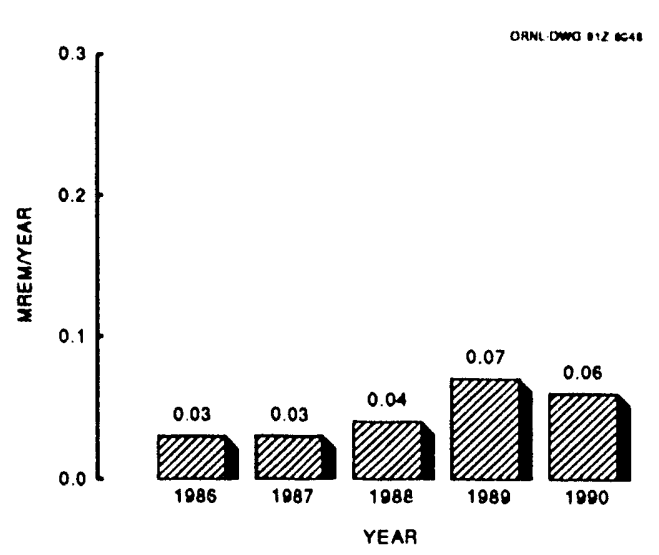

Fig. 5. Maximum predicted individual EDE from airborne radionuclides, 1986-1990.

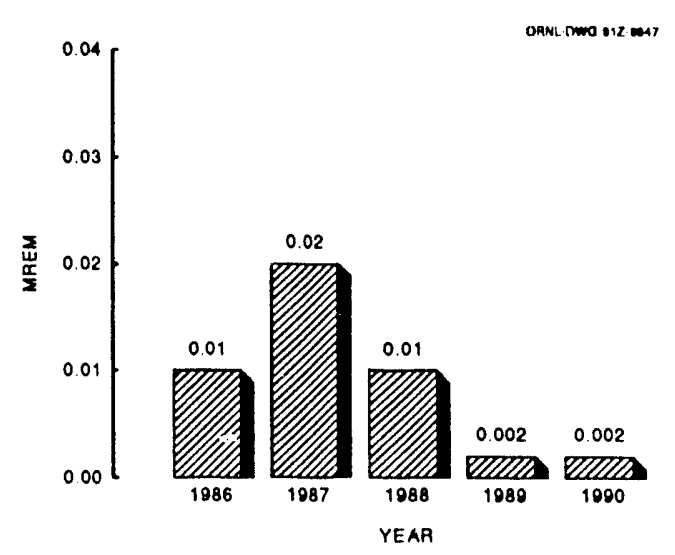

Fig. 6. Maximum predicted individual EDE from waterborne radionuclides, 1986-1990.

the appropriate agencies. The storage of hazardous chemicals is required by SARA Sect. 312 for listed chemicals above the threshold-planning quantities for the chemicals. Typical chemicals included are chlorine, Freon-114, gasoline, fluorine, hydrogen fluoride, various acids, and uranium hexafluoride.

Chemical releases under SARA are covered under Sect. 313. If a Sect. 313 chemical is manufactured, 
processed, or otherwise used in excess of a set amount, then releases to the environment of that chemical must be reported to EPA and OEPA. Approximately $95,856 \mathrm{~kg}(210,884 \mathrm{lb})$ of listed chemicals was released to the environment.

\section{AUDITS AND REVIEWS}

The PORTS Environmental Protection Program undergoes rigorous annual appraisals, audits, and reviews by both internal and erternal organizations. All appraisals, audits, and reviews may result in recommendations requiring operating contractor management attention. Recommendations on environmental issues result in development and implementation of corrective actions formulated to improve overall site environmental protection.

Appraisals, audits, and reviews of the site Environmental Protection Program conducted during 1990 included a Multi-Media Environmental Audit by EPA in August; a RCRA Compliance Inspection by OEPA in September; a Corporate Audit Review by Energy Systems in October; a follow-up Tiger Team Review by DOE in October; an Environmental Compliance Review by Energy Systems in November; and an Environmental Restoration and Waste Management Audit by DOE in December.

\section{ABNORMAL OCCURRENCES}

Corrosion inside a condensor caused an unplanned release of uranium to the East Drainage Ditch. A tube corroded through and allowed uranium-bearing solutions that were being treated to recover the uranium to leak to the plant storm sewer along with once-through cooling water. The incident added noticeably to the 1990 waterborne uranium emissions but had no significant impact on the surrounding environment or the public health.

\section{SOLID WASTE MANAGEMENT}

In accordance with RCRA and the Ohio Solid Waste Act, the Solid Waste Management Program at PORTS includes solid, liquid, semisolid, or contained gas that is being discarded. The purpose of the program is to manage the accumulation, treatment, storage, ar : lisposal of all discarded solid waste and to ensure compliance with solid waste regulations and policies. The Solid Waste Management Program is administered by two departments, the Waste
Management Department and the Environmental Control Department.

The goals of PORTS' solid waste management are

- to ensure compliance with all federal, state, and local regulations;

- to minimize the volume and hazard of all hazardous and radioactive wastes produced;

- to protect the environment from unintentional releases of hazardous or radioactive materials;

- to protect personnel from hazards associated with handling solid wastes; and

- to minimize the long-term risks and liability for waste disposal.

Waste minimization strategies include segregation, material substitution, process changes, mechanical compression volume reduction, and recycling and reuse.

Environmental protection is provided by the use of specification packaging and by storage in properly engineered and permitted facilities. An extensive inspection and audit program is in place to identify and correct deficiencies. Personnel protection is provided through standard industrial protection equipment applied in accordance with requirements determined from Materials Safety Data Sheets and Industrial Hygiene/Health Physics recommendations. Long-term risks and liabilities for disposals are minimized by destroying or removing the hazardous constituent whenever possible, as opposed to burial or storage.

PORTS solid waste is managed in five different categories: radioactive wastes; classified wastes; hazardous wastes as defined by RCRA; polychlorinated biphenyls and asbestos, which are regulated by the Toxic Substances Control Act (TSCA); and conventional solid wastes, which are generally managed by sanitary landfill. Medical and infectious wastes are a special subcategory of cotiventional solid wastes. Trends in the generation of PORTS waste streams are indicated in Figs. 7 through 18.

PORTS stores RCRA, TSCA, radioactive, and nonregulated wastes in accordance with applicable regulations and DOE orders. PORTS disposal facilities are a sanitary landfill, a classified landfill, and a radioactive landfill. Construction spoils landfills are used to dispose of nonregulated waste to 


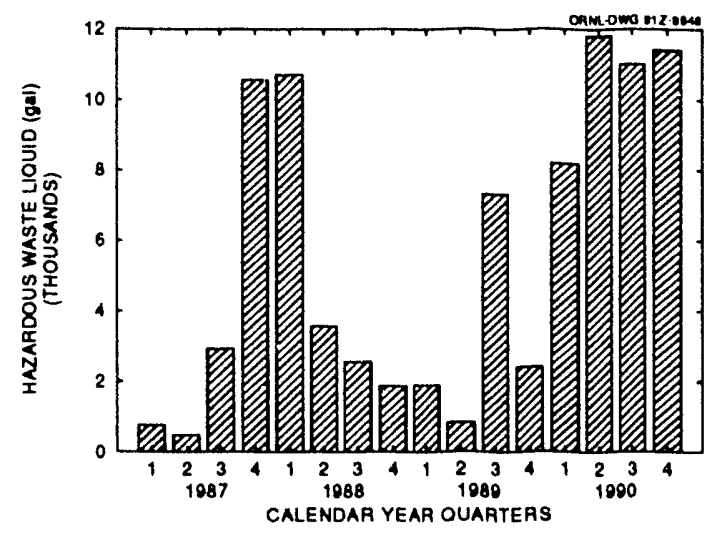

Fig. 7. Liquid hazardous waste by quarters.

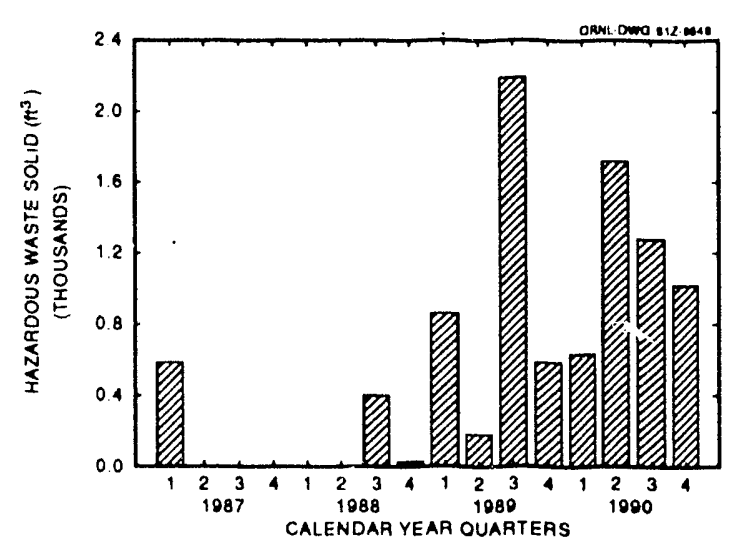

Fig. 8. Solid hazardous waste by quarters.

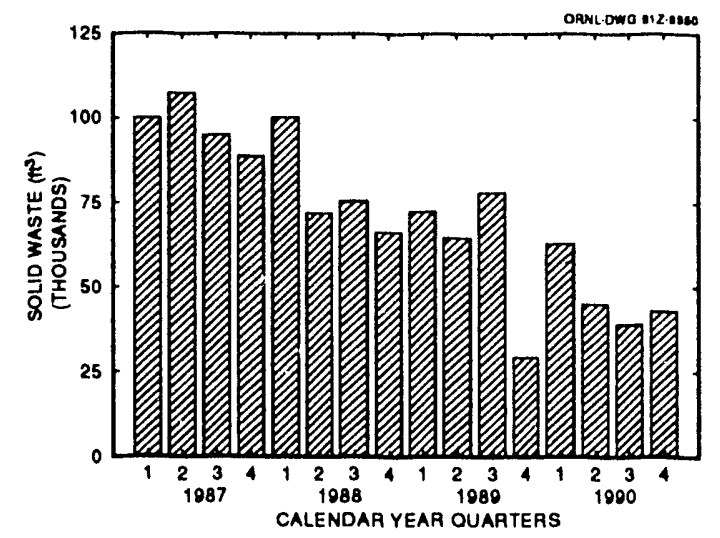

Fig. 9. Sanitary waste by quarters.

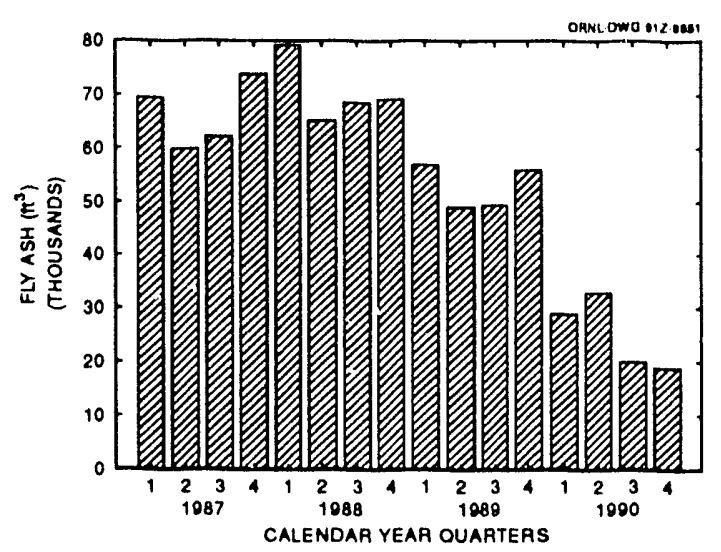

Fig. 10. Fly ash by quarters. 


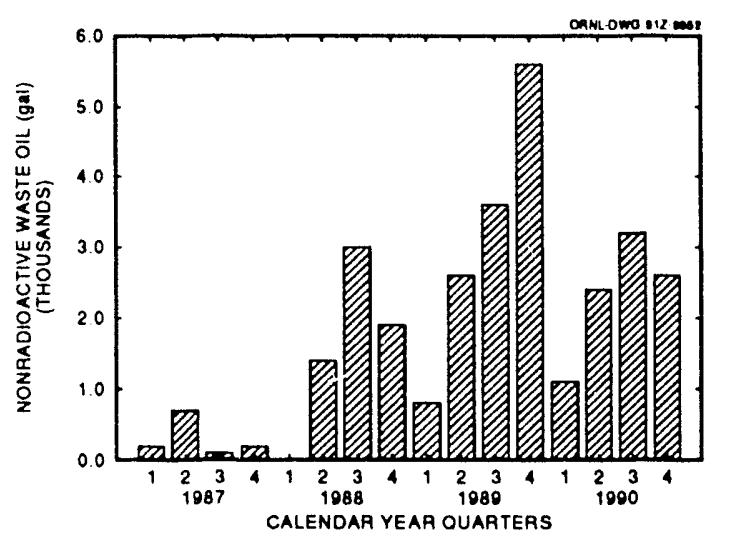

Fig. 11. Nonradioactive waste oil by quarters.

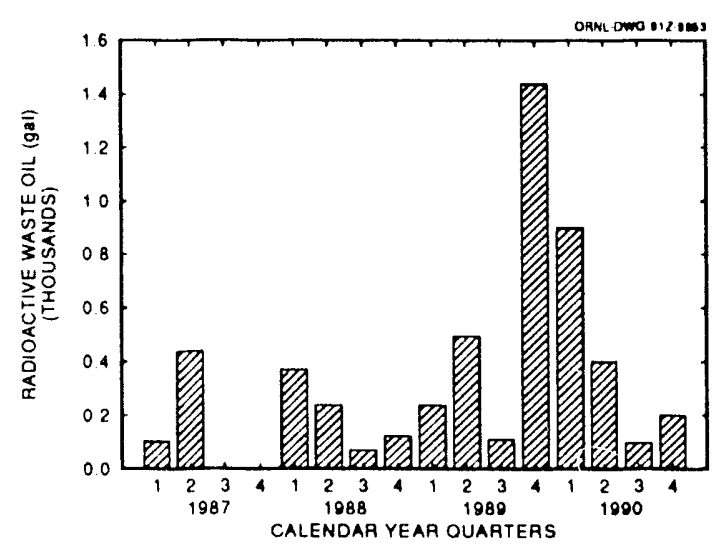

Fig. 12. Radioactive waste oil by quarters.

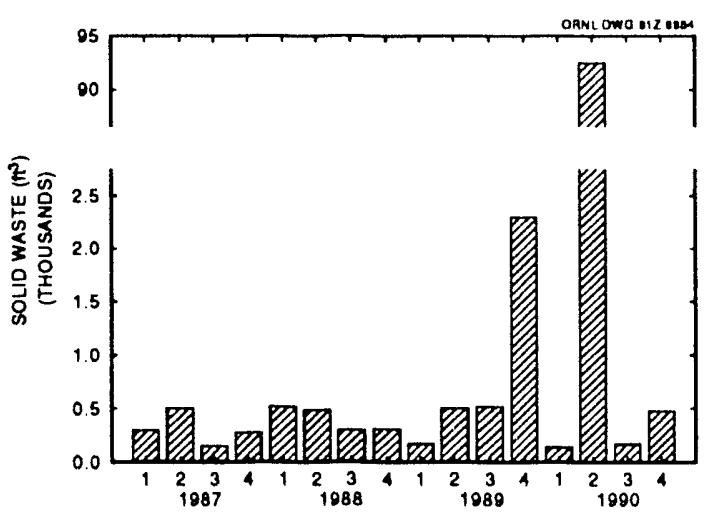

Fig. 13. Solid mixed hazardous wastes by quarters.

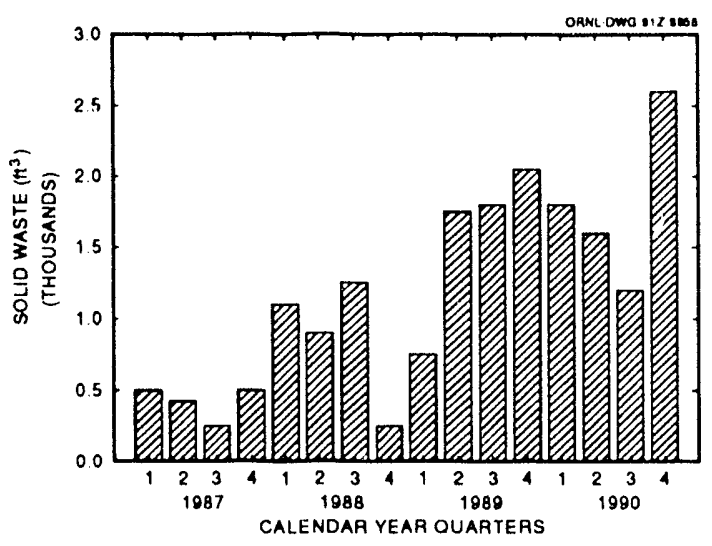

Fig. 14. Solid mixed PCB waste by quarters. 


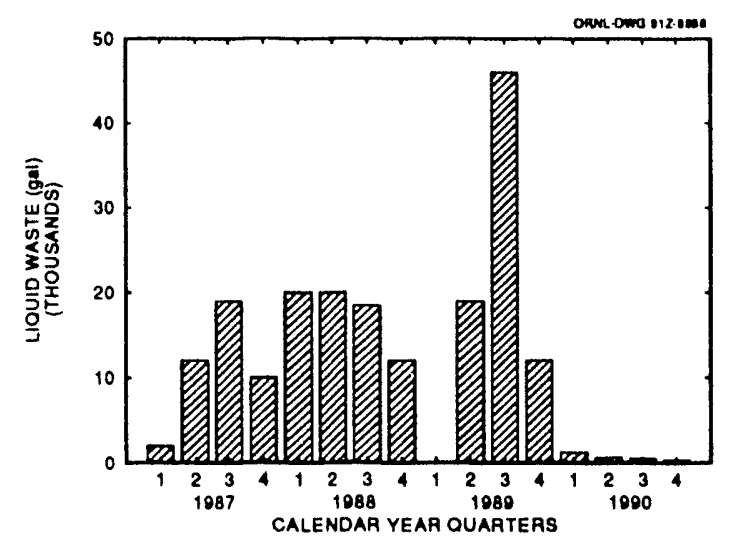

Fig. 15. Liquid PCB waste by quarters.

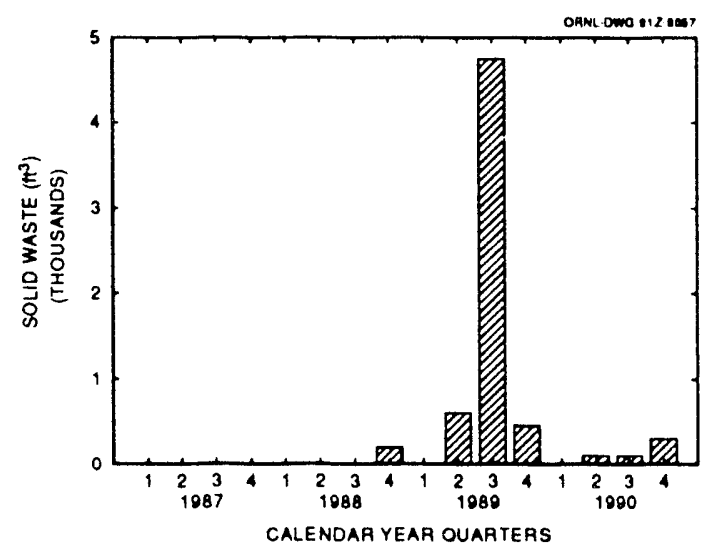

Fig. 16. Solid PCB waste by quarters.

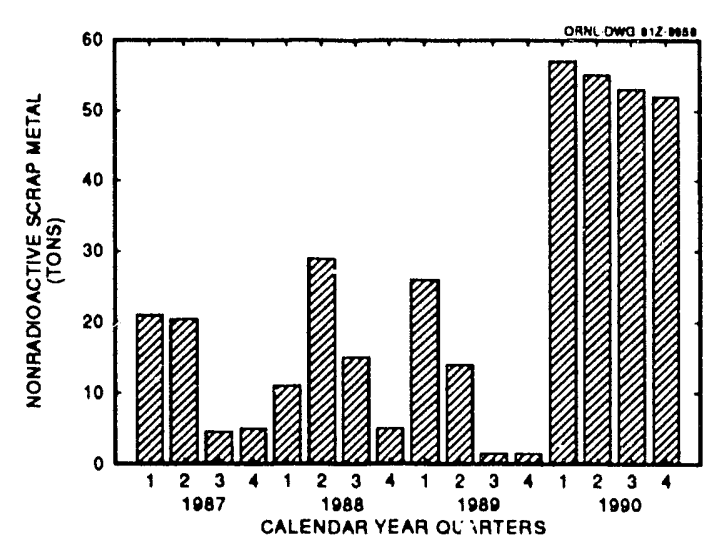

Fig. 17. Nonradioactive scrap metal by quarters.

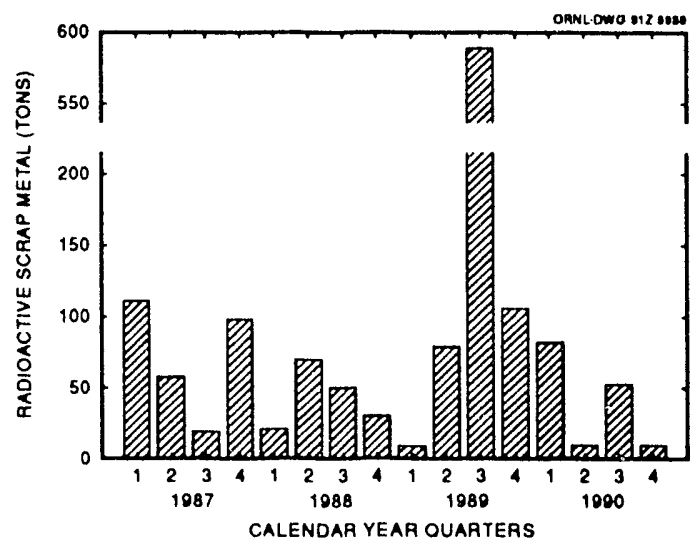

Fig. 18. Radioactive scrap metal by quarters. 
conserve the area dedicated for use as the sanitary landfill.

The facilities administerec by the DOE Oak Ridge Operations office, including PORTS, have undertaken a Low. Level Waste Disposal Development and Demonstration (LLWDDD) Program to develop, demonstrate, and evaluate low-level waste disposal options for the fluture. The LLWDDD Program is defining $\mathrm{F}^{\wedge} \mathrm{rformance}$ paramet ?rs that future waste disposal facilities must achieve These parameters are to be consistent with Nuclear Regulatory Commission regulations and with the advice of area EPA regulators.

The Hazardo'ss Waste Deveiopment, Demonstration, and Disposal F.ogram is similar to the LLWDDD Program but addresses hazardous and mixed wastes for Energy Systems installations. PORTS uses commercial dispesal of RCRA- and TSCA-regulated wastes to the maximum extent possible for nonradioactive wa ites. Thermal $c$ i chemical destruction of the ha; yrdous constituents is used whenever possible. Use of chemical waste landfills is minimized. The use of commercial facilities for treating radioactive wastes is being investigated. The 1990 off-site waste shipments also are summarized in this report.

\section{ENVIRONMENTAL MONITORING AND SAMPI.ING SUMMARY}

Routine monitoring and sampling for radiation, radioactive materials, and chemical substances on and off the PORTS site ara used to document compliance with appropriate standards, to identify trends, to provide information for the public, and to contribute to general environmental knowledge. The surveillance program assists in fulfilling the DOE policies of (1) protecting the public, employees, and the environment from harm that could be caused by its activities and (2) reducing negative environmental impacts to the greatest degree practicable.

Monitoring and sampling locations for various types of measurements are organized into three groups:

- off-site stations located some distance from the DOE Reservation in residential and community areas to document conditions in areas occupied and visited by the public and potentially affected by DOE installations,

- perimeter stations located on the boundaries of the DOE Reservation, and

- on-site stations lecated in PORTS areas accessible only 10 employees or authorized visitors.

In 1990, approximately 100,000 measurements were taken in various environmental media.

A summary of the SARA Title III report is given in the appendix. The SARA report provides information about estimated quantities of certain toxic chemicals used at the facility that routinely are or potentially could be released into the environment during an accident. The appendix includes some additional "large quantity" chemicals used at the facility for which reporting is not required by SARA Title III, but that are known to be emitted from the facility. The appendix is not all-inclusive, but it provides information on the major chemical emissions to the air, water, or land from processes at the facilities. 


\section{COMPLIANCE SUMMARY ENVIRONMENTAL COMPLIANCE ACTIVITY U.S. DEPARTMENT OF ENERGY}

\section{PORTSMOUTH GASEOUS DIFFUSION PLANT}

\section{BACKGROUND AND OVERVIEW}

The Portsmouth Gaseous Diffusion Plant (PORTS) cperates in conformance with requirements established by a number of federal and state statutes and regulations, Executive Orders, U.S. Department of Energy (DOE) Orders, and compliance and settlement agreements. Compliance status with regard to major environmental statutes is summarized below:

\section{Clean Air Act and National Emissions Standard for} Hazardous Air Pollutants (NESHAP)

PORTS has ten state air permits with an additional 81 air emission sources registered with the Ohio Environmental Protection Agency (OEPA).

Nine radiological stacks are equipped with continuous stack samplers to monitor radiological emissions. Seventeen field air-monitoring stations are used to monitor environmental air emissions, ( 6 on-site, 8 property line, and 3 off-site). PORTS radio ogical air emissions are well within the newest NESHAP standards. Stack monitors are being added, and field samplers are being upgraded to comply with the riew NESHAP monitoring requirements. Permit applications have now been submitted to OEPA for all ideritified air emission sources. Unpermitted sources and procedurat violations had been identified in the past; however, recent improvements should result in full compliance.

\section{Clean Water Act}

The PORTS National Pollutant Discharge Eliminations System (NPDES) permit encompasses 20 monitored outfalls, 14 of which are classified as point source discharges. Three wastewater treatment facilities have been constructed and brought on-line since 1983. NPDES excursions and spills have resulted in some parameters exceeding NPDES permit limits; however, progress continues in minimizing these incidents and their effects on receiving streams.

\section{Resource Conservation and Recovery Act (RCRA)}

PORTS operates four interim status RCRA storage facilities. Four RCRA facilities currently have approved closure plans, and a RCRA incinerator has been closed and inspected and is awaiting OEPA approval. Additionally, four 90-day storage areas are established for temporary storage of hazardous wastes. There are 87 solid waste management units identified for further study under the 3004(u) remedial action program. A RCRA inspection performed by OEPA in September 1990 indicated several deficiencies; however, recent improvements, including the formation of a Waste Management Division to focus attention on waste issues, have resulted in a substantially upgraded program. A Consent Decree with the state of Ohio and a Consent Order with EPA have been negotiated and signed.

\section{Toxic Substances Control Act (TSCA)}

PORTS operates four waste storage areas for polychlorinated biphenyls (PCBs). All storage areas meet the storage requirements of TSCA regulations. The current plant-site inventory of PCBs in electrical equipment (and spare equipment) is approximately 1.2 million $\mathrm{kg}$. PORTS is generally in compliance with TSCA; however, compliance issues exist 
regarding non-totally enclosed systems that are contaminated with $\mathrm{PCBs}$ and regarding the storage of uranium-contaminated $\mathrm{PCB}$ wastes beyond the one-year TSCA limit (see Current Issues below for details).

\section{Underground Storage Tanks (USTs)}

Underground storage tank (UST) activities included removal, repair, and closure in CY 1990. Three UST systems were removed from the ground and the sites remediated; no further actions are required for these three sites. Two UST systems were repaired. One UST was determined to be a hazardous waste tank; its operation was halted immediately. Removal of this tank is pending EPA approval of the closure plan. Two new double-walled fiberglass USTs were installed and placed in operation.

The Ohio State Fire Marshal UST Registration Permit Application was reviewed and updated. Tanks exempted or deferred from registration for various reasons (c.g. vaulted or flow-through tanks) were deleted from the application.

A contract was put in place with a consultant to review the available information on PORTS UST systems and evaluate routinely generated level measurements in support of the release detection program. The consultant provided tank-specific "inches to gallons" conversion charts, invantory control/fuel handling procedures, and training. The training provided UST operators with directions for the method of inventory control to be used on their tanks, inventory control forms, conversion charts, and spill/overfill procedures.

\section{National Environmental Policy Act (NEPA)}

NEPA requires evaluation of environmental impacts for activities at federal facilities and for activities funded with federal dollars. All projects falling under the purview of NEPA are examined for environmental impacts related to (1) property (e.g. sites, buildings, structures, and objects) of historic, archaeologic, or architectural significance, as officially designated by federal, state, or local governments, including those eligible for listing on the National Register of Historic Places; (2) potential habitat (including critical habitat) of federally-listed endangered, threatened, proposed, or candidate species or of state-listed endangered and threatened species; (3) floodplains and wetlands; (4) natural areas such as federally- and state-desienated wilderness areas, national parks, national natural landmarks, wild and scenic rivers, coastal zones, state and federal wildlife refuges, and marine sanctuaries; (5) prime agricultural lands; and (6) special sources of water (such as Class I groundwater, sole-source aquifers, wellhead protection areas, and other water sources that are vital in a region).

PORTS has a formal program dedicated to compliance with NEPA pursuant to DOE Order $5440.1 \mathrm{c}$. The NEPA compliance program is a portion of the Environmental Control Department in the Environmental, Safety, and Health Division. All engineering projects, maintenance activitics, operations, remedial actions, and waste management activities are evaluated to determine the appropriate level of NEPA documentation required. NEPA documents are produced by NEPA Compliance Program personnel and submitted to DOE for evaluation and approval.

During CY 1990 the PORTS NEPA program accomplished the following:

- Filled the NEPA Compliance Coordinator position in the Environmental Control Department. The NEPA Compliance Coordinator assesses enginecring projects, maintenance activities, and operations activities, as well as other plant site operations for NEPA concerns.

- Filled the NEPA clerk position in the Environmental Control Department. The NEPA clerk tracks and coordinates NEPA record keeping.

- Filled the NEPA Planning Coordinator position in the Enginecring Division. The NEPA Planning Coordinator manages NEPA activities for the Engincering Division.

- Developed a NEPA tracking and record-kecping system using a relational database (ORACLE). The system is custom designed to meet the specific needs of the PORTS NEPA program and can be readily modified to accommodate new program requirements.

- Developed categorical exclusion determinations (CXs) for routine mair snance activitics and submitted the CXs to DOE headquarters for evaluation and approval.

- Initiated development of a program to audit and assess NEPA requirements for all routine maintenance activitics. 
- Modified the PORTS NEPA program in accordance with the directives issued in Secretary of Energy Notice-15-90.

- Initiated biannual meetings between the NEPA Compliance Coordinator and Project Management that identify the appropriate level of NEPA documentation for upcoming projects.

- Submitted approximately 200 NEPA assessments and revisions to DOE headquarters for approval and evaluation. In 1990, 76 fully approved NEPA documents were received at PORTS.

- Revised the interdivisional agreement between Engineering and Environmental Control for NEPA compliance (POEF-E-3/8).

- Revised NEPA procedural document (ESH-E-903) to reflect recent changes in the DOE headquarters NEPA process.

\section{Federal Insecticide, Fungicide, and Rodenticide Act}

No restricted-use pesticides are used by PORTS personnel. If application of a restricted-use pesticide at the plant is necessary, a certified contractor will be used to make the application. Ge.ieral-use pesticides used at the plant by plant personnel are used in a manner consistent with the product labeling. All product warnings and cautions are strictly obeyed. Applications of pesticides by plant and contractor personnel must be approved by the Plant Pesticide Coordinator.

\section{Safe Drinking Water Act}

Portsmouth operatcs 30 potable water wells located in four well fields, but the plant also has the capability to utilize surface water from the Scioto River. Additionally, Portsmouth operates a lime-softening water treatment facility with a maximum daily flow of 40 million gallons per day (MGD). Current daily flow is approximately 16 MGD.

Portsmouth monitors routinely for a number of chemical operational requirements, including coliforms. Sampling is also performed for gross alpha and beta and the MCL compliance package. Additionally, sampling for volatile organic chemicals (VOCs) for the first quarter has been submitted for analysis. All sample results are forwarded to OEPA for review. Portsmouth is evaluated annually by
OEPA. No findings have been noted for a number of years.

\section{CURRENT ISSUES}

In addition to the general trends discussed above, a number of specific compliance issues have been identified. These significant issues are addressed below. Although they remain unresolved, they are well-defined, and actions necessary for their resolution have been initiated.

\section{Parameters in Excess of NPDES Permit Limits}

Kainfall runoff and algae growth routinely have resulted in total suspended solids and $\mathrm{pH}$ exceedances, respectively. New NPDES permit limits are still being negotiated for $\mathrm{pH}$ and total suspended solids due to these causes. Draining ponds to reduce algae growth and lower $\mathrm{pH}$ values, dredging ponds to reduce total suspended solids, and other measures are being implemented to eliminate these occurrences. Efforts to improve compliance are showing significant progress. The number of exceedances was reduced to 67 during 1990, a 27\% reduction from 92 in the previous year.

\section{Unpermitted Air Emissions}

A total of 431 small point sources, 5 purge cascade process vents, and 2 cooling tower systems have not been permitied or exempted by OEPA at Portsmouth. Permit applications for cooling tower emissions, small point sources, purge cascade emissions, and process vents have been submitted to OEPA for its determination of regulatory compliance status.

NESHAP regulations required demonstration of compliance with the airborne radionuclide standard by March 15, 1990. PORTS is awaiting EPA's approval of expanded source monitoring and an ambient air monitoring plan that was revised and resubmitted on February 11, 1991 ( originally submitted on March 7, 1990) to demonstrate compliance with the regulation. Plans are being developed so that implementation of the program can proceed as soon as possible after EPA approval. 


\section{Land Disposal Restricted (LDR) Waste}

Currently, PORTS is storing liquid, low-level radioactive waste that also contains RCRA hazardous waste. This waste is subject to the RCRA land ban provisions which permit storage only for accumulating sufficient quantities to facilitate proper treatment, recycle or disposal. This waste is stored because of the nationwide shortage of treatment and disposal facilities for these types of wastes. During 1991 and 1992, DOE Oak Ridge Operations Office will negotiate a Federal Facilities Compliance Agrecment (FFCA) that will detail steps required to attain compliance. A draft FFCA that addresses spent solvents and California-listed RCRA waste streams is being prepared. The K-1435 TSCA Incinerator has been constructed at the K-25 Site in Oak Ridge, Tennessee that will be capable of incinerating LDR liquid organic waste that is hazardous and radioactive.

\section{Mixed TSCA Waste Storage}

Uranium-contaminated PCB wastes (mixed wastes) are being stored in excess of the one-year limit imposed by TSCA due to the lack of commercial mixed waste disposal capabilities. This storage does not have official regulatory concurrence to date; however, EPA has incorporated such concurrence into the draft compliance agreement being negotiated between DOE and EPA. These PCB wastes will be destroyed in the K-1435 TSCA Incinerator at the K-25 Site.

\section{X-735 Sanitary Landfill}

It was discovered that PORTS had disposed of RCRA-listed solvent-contaminated rags and wipes in the X-735 Sanitary Landfill, which is not a RCRA-permitted landfill. PORTS has submitted a proposal to OEPA for approval in managing this problem. Current plans include closure of the portion of the X-735 laridfill that has already been used as a RCRA facility. The rest of the landfill will continue to be used.

\section{PCB-Contaminated RCRA Remedial Action Sludge}

EPA has concluded that the sludge stored as a result of the RCRA cleanup of the X-701B Holding Pond containing PCBs is also regulated by TSCA. This waste is currently being stored in accordance with RCRA regulations, but not in compliance with TSCA regulations. This waste also contains various amounts of uranium and technetium. The storage area will be upgraded to meet TSCA standards as well as RCRA standards; PORTS is applying to EPA for an exemption to use the present storage containers with PCB labeling.

\section{PCB-Contaminated Oil}

Some unit hydraulic/lube oil systems constitute PCB-contaminated non-totally enclosed systems. A project is underway to remove $\mathrm{PCBs}$ from the contaminated lube oil systems.

Oil drips from $P C B$ ventilation gaskets are considered PCB spills. TSCA requires extensive documentation and immediate cleanup action and verification after discovery. Presently, PORTS conducts daily inspections to identify leaks and initiates needed cleanup within 24 hours as required by the EPA Spill Cleanup Policy contained in TSCA. Individual sampling for cleanup verification, also required by this policy, is not presently being performed due to the large number of drips occurring. A statistical sampling system is being used instead. A drip collection system has been installed under existing leaks; eventually a drip collection system will include all motor exhaust duct gaskcts. Following installation, all new ventilation gasket drips will be cleaned up in accordance with TSCA policy, including verification of cleanup results. In addition, immediate installation of drip collection troughs will be performed for new leaks. Discussions between DOE and EPA concerning the use of PCB gaskets in "open" systems and appropriate cleanup procedures are continuing.

Inappropriate containers are being used to store PCB liquids that may contain high-assay uranium. Five-inch-diameter containers are required to satisfy Nuclear Criticality Safety requirements for unknown or high-assay uranium-bearing matcrials. No DOT-approved containers of these dimensions are commercially available in the types authorized by TSCA. This issue is being incorporated into the FFCA, which also addresses the storage of mixed $\mathrm{PCB} /$ radioactive waste. 


\section{Tiger Team Assessment}

In October and November of 1989, an extensive audit was conducted by a DOE Tiger Team. This audit was a comprehensive, facility-wide evaluation of all environmental media and adherence to applicable federal, state, and local regulations, requirements, and best management practices. The environmental areas addressed included air, surface water/drinking water, groundwater/soils, active wastes management/underground storage tanks, toxic and hazardous materials and associated QA, radioactive materials management, $\mathrm{QA}$, inactive waste sites/emergency response, and NEPA. Team specialists in each of the respective disciplines evaluated concerns, facility-wide, through extensive reviews of PORTS plant production, processes, training, record keeping, and procedures. In addition to environmental concerns, the Tiger Team review also addressed management and health and safety disciplines. A total of 187 findings and issues were reported; 115 were nonenvironmental, and 72 were environmental.

The Environmental Control Department has submitted and implemented corrective-action-plans to address all environmental deficiencies. Of the 72 environmental findings/issues, 35 were Compliance Findings (CF) and 37 were Best Management Practices (BMP).

By the end of CY -199017 of the CFs were closed and 18 of the BMPs were closed. All open issues currently are being addressed through appropriate corrective actions. 


\section{CONTENTS}

Page

EXECUTIVE SUMMARY $\ldots \ldots \ldots \ldots \ldots \ldots \ldots \ldots$ iii

COMPLIANCE SUMMARY $\ldots \ldots \ldots \ldots \ldots \ldots \ldots \ldots \ldots \ldots \ldots \ldots \ldots$

ABBREVIATIONS, $\triangle$ CRONYMS, AND INITIALISMS $\ldots \ldots \ldots \ldots \ldots \ldots$ xxiii

PART 1: NARRATIVE, SUMMARIES, AND CONCLUSIONS $\ldots \ldots \ldots \ldots$

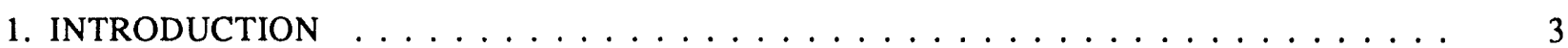

1.1 OPERATIONS OF THE PORTSMOUTH SITE $\ldots \ldots \ldots \ldots \ldots \ldots$

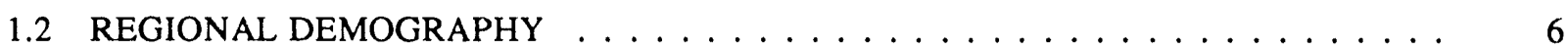

1.3 GEOLOGY AND GROUNDWATER $\ldots \ldots \ldots \ldots \ldots \ldots$

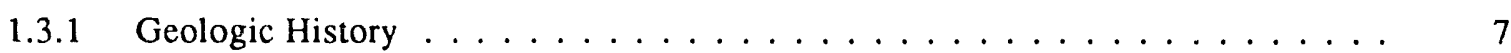

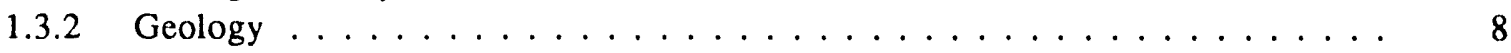

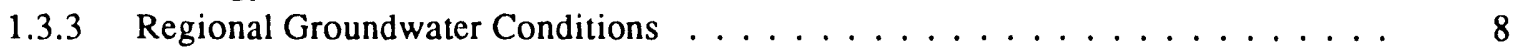

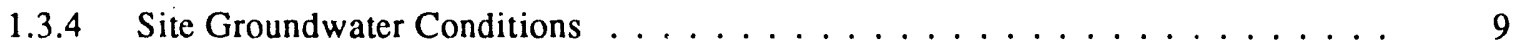

1.4 TOPOGRAPHY AND SURFACE WATER $\ldots \ldots \ldots \ldots \ldots \ldots \ldots$

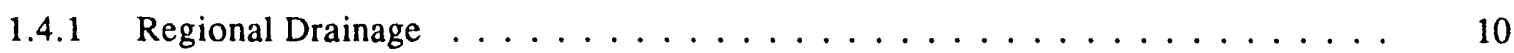

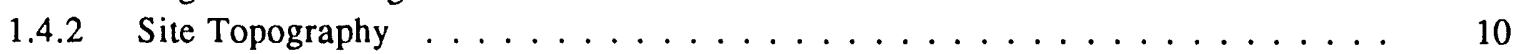

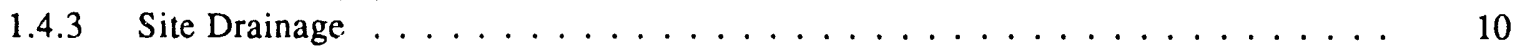

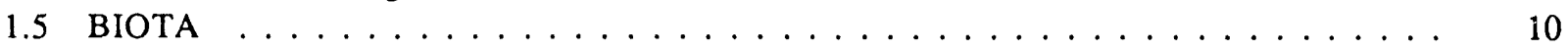

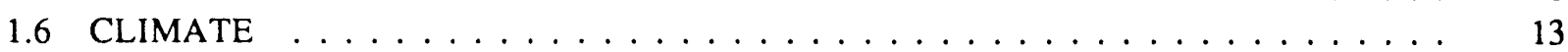

2. AIRBORNE DISCHARGES, AMBIENT AIR MONITORING,

METEOROLOGICAL MONITORING, AND EXTERNAL GAMMA RADIATION $\ldots \ldots \ldots$

2.1 EMISSION MONITORING $\ldots \ldots \ldots \ldots \ldots \ldots \ldots \ldots \ldots$

2.1.1 Description of Emission Sources and Monitoring Systems . . . . . . . . . . 17

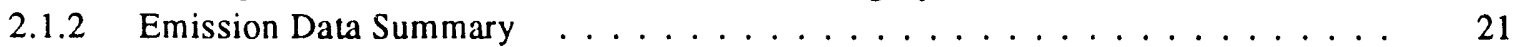

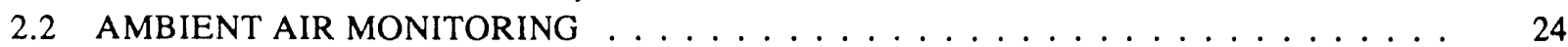

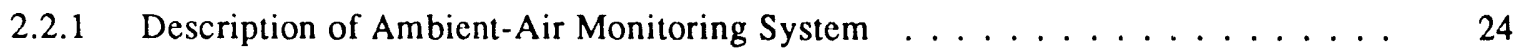

2.2 .2 Ambient Air Data Summary . . . . . . . . . . . . . . . . . . 25

2.3 METEOROLOGICAL MONITORING $\ldots \ldots \ldots \ldots \ldots \ldots \ldots \ldots$

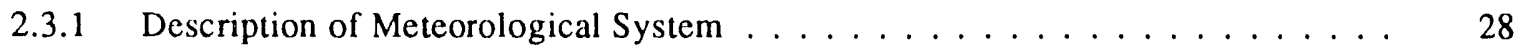

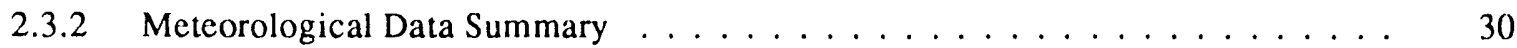

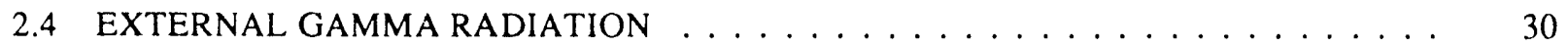

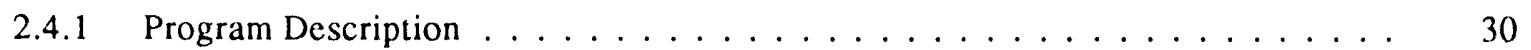

2.4.2 Thermoluminescent Dosimeter Data Summary . . . . . . . . . . . . . . . . . 34

2.5 FINDINGS AND CONCLUSIONS $\ldots \ldots \ldots \ldots \ldots \ldots \ldots$ 


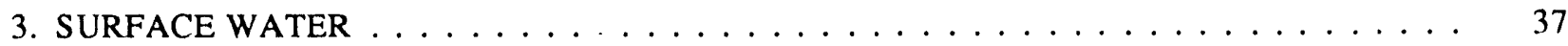

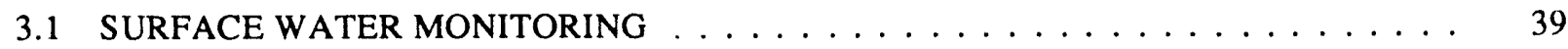

3.2 NATIONAL POLLUTANT DISCHARGE ELIMINATION

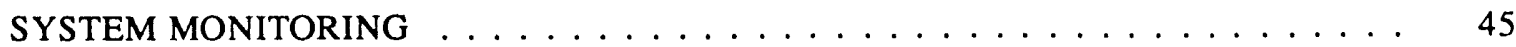

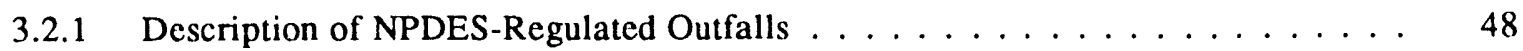

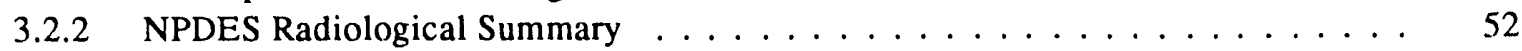

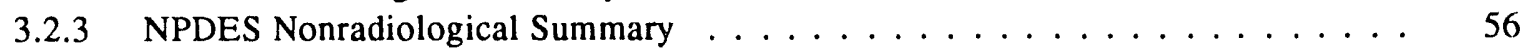

3.3 POLLUTION ABATEMENT PROJECTS AND ACTIVITIES $\ldots \ldots \ldots \ldots \ldots \ldots$

3.4 FINDINGS AND CONCLUSIONS $\ldots \ldots \ldots \ldots \ldots \ldots \ldots \ldots \ldots \ldots$

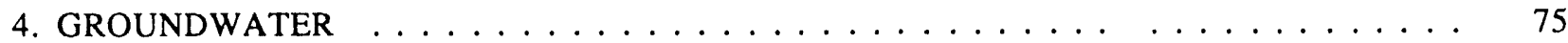

4.1 GROUNDWATER MONITORING PROGRAM DESCRIPTIONS . . . . . . . . . 77

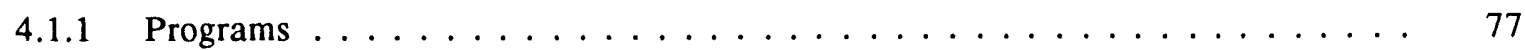

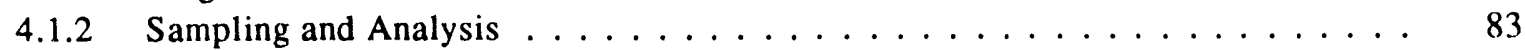

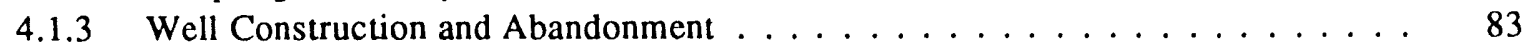

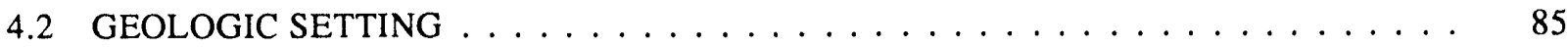

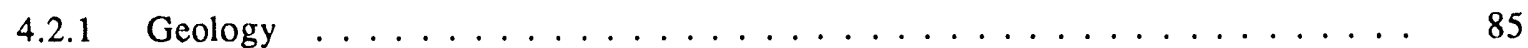

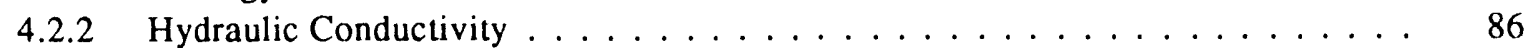

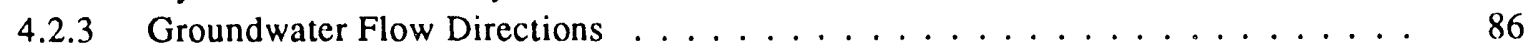

4.3 DATA SUMMARY AND ANALYSIS $\ldots \ldots \ldots \ldots \ldots \ldots$

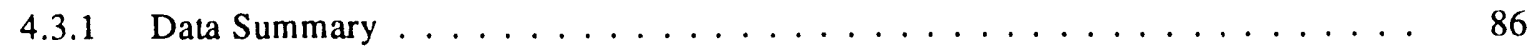

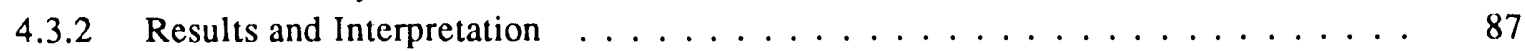

5. BIOLOGICAL SAMPLING $\ldots \ldots \ldots \ldots \ldots \ldots \ldots \ldots$

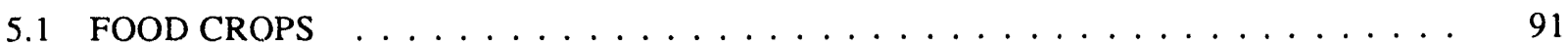

5.1 .1 Program Description $\ldots \ldots \ldots \ldots \ldots$

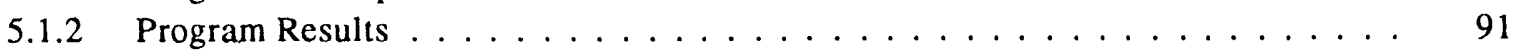

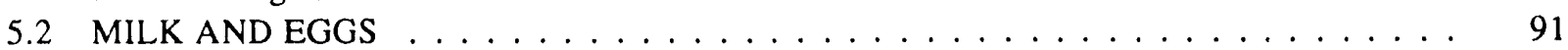

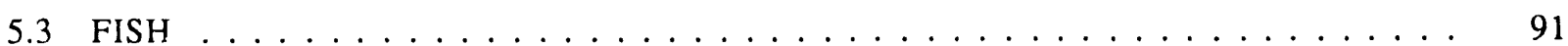

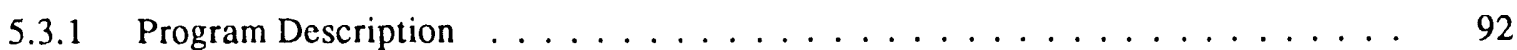

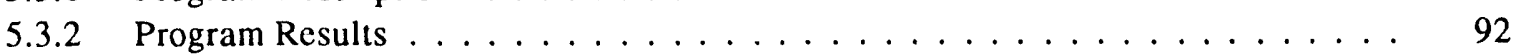

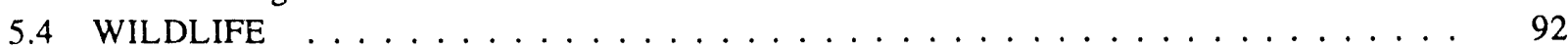

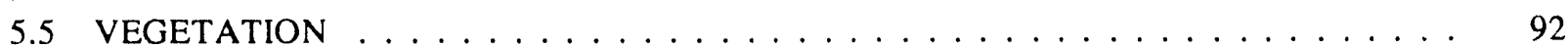

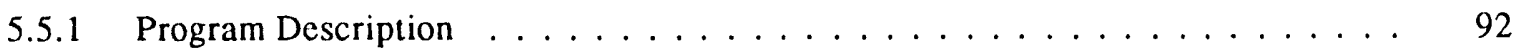

5.5 .2 Program Results . . . . . . . . . . . . . . . . . . . 93

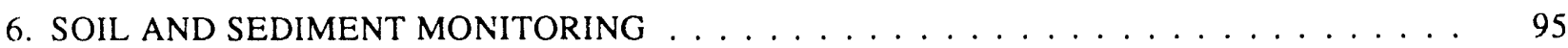

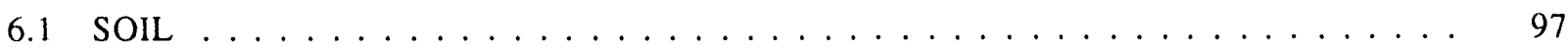

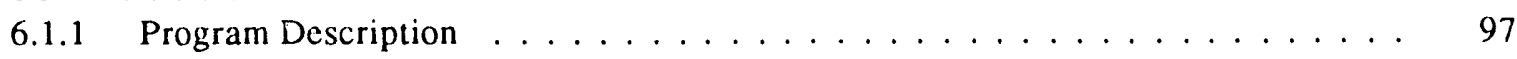

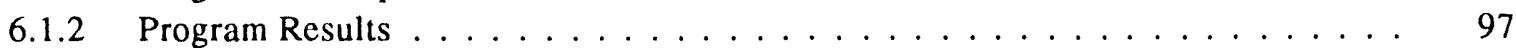

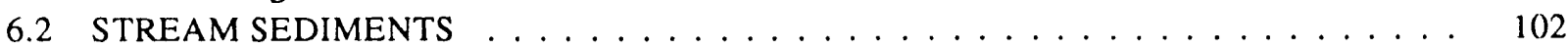

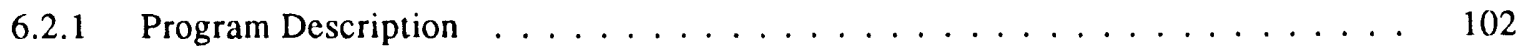

6.2 .2 Program Results . . . . . . . . . . . . . . . . . . . . . . . 104

7. POTENTIAL RADIATION AND CHEMICAL DOSE TO THE

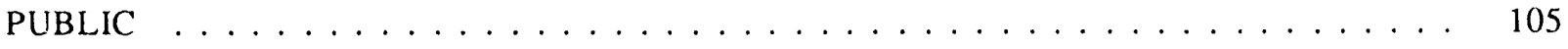

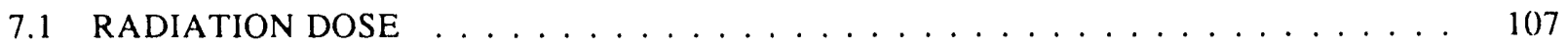

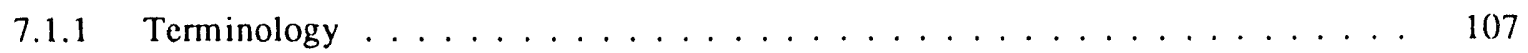

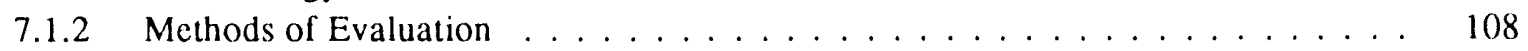


7.1.3 Doses to Aquatic Biota . . . . . . . . . . . . . . . . . . . . . . . 109

7.1 .4 Current Year Summary . . . . . . . . . . . . . . . . . . . . . . 109

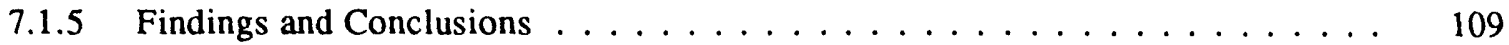

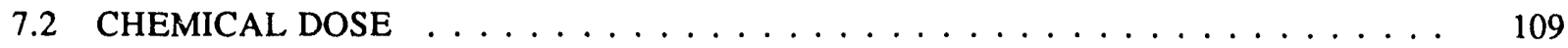

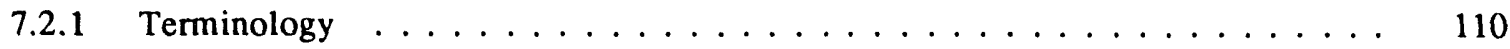

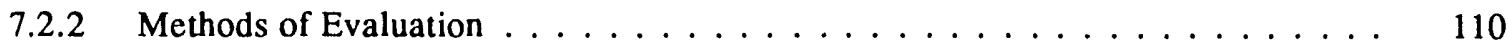

8. SOLID WASTE MANAGEMENT PROGRAM $\ldots \ldots \ldots \ldots \ldots \ldots \ldots \ldots \ldots \ldots$

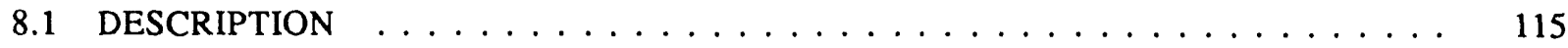

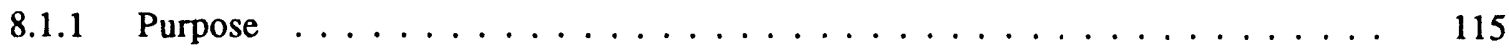

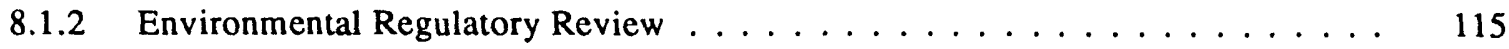

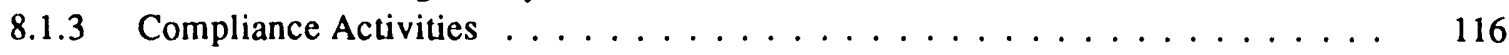

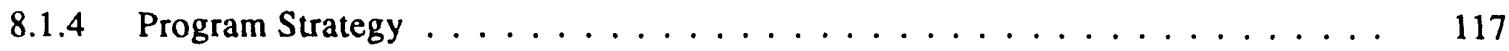

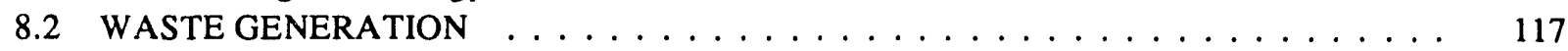

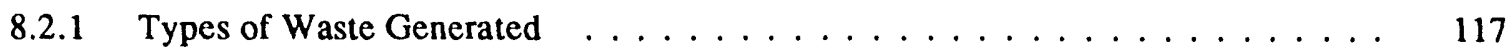

8.2 .2 Waste-Generating Activities $\ldots \ldots \ldots \ldots \ldots \ldots \ldots \ldots$

8.3 WASTE MANAGEMENT ACTIVITIES $\ldots \ldots \ldots \ldots \ldots \ldots \ldots \ldots \ldots$

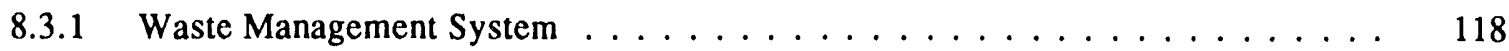

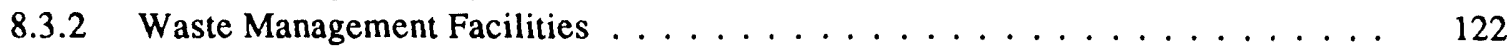

8.3.3 Off-Site Disposal Activities . . . . . . . . . . . . . . . . . . . . 124

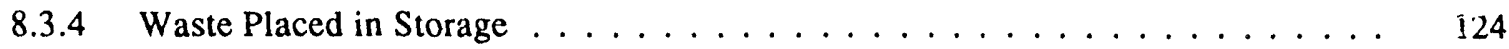

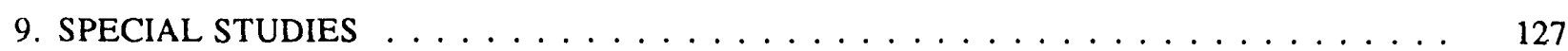

9.1 PORTSMOUTH GASEOUS DIFFUSION PLANT SPILL REPORT . . . . . . . . . . . . . . 129

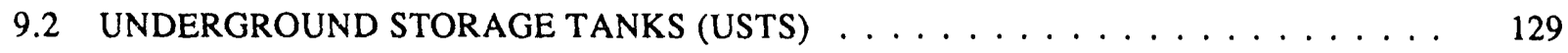

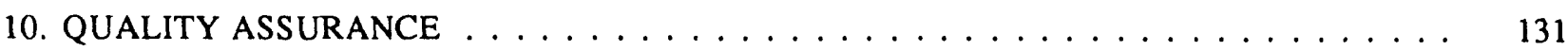

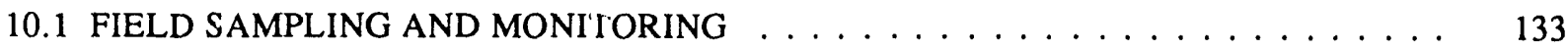

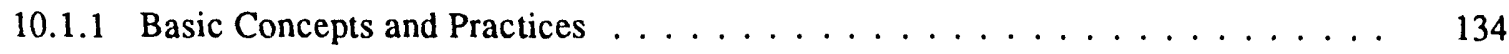

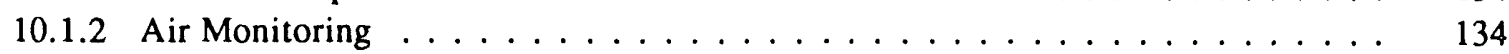

10.1.3 Surface Water Monitoring . . . . . . . . . . . . . . . . . . . . . . . . . . . . . . . . . . . . . . . . . . . . . . . . .

10.1 .4 Groundwater Monitoring . . . . . . . . . . . . . . . . . . . . . . . . . . . . . . . . . . . . . . .

10.1.5 Biological Monitoring . . . . . . . . . . . . . . . . . . . . . . . . . . . . . . . . . . . . . . . . . . . .

10.1.6 Soil and Sediment Monitoring . . . . . . . . . . . . . . . . . . . . . . . . . . . . . . . . . . . . . . . . . . .

10.1.7 External Gamma Radiation . . . . . . . . . . . . . . . . . . . . . . . . . . . . . . . . . . . . . . . . . . . . . . .

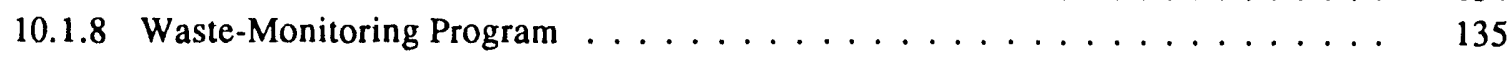

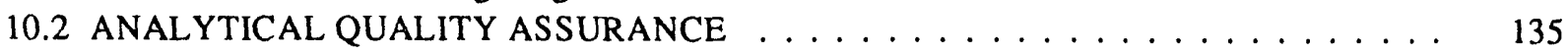

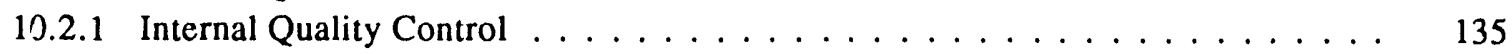

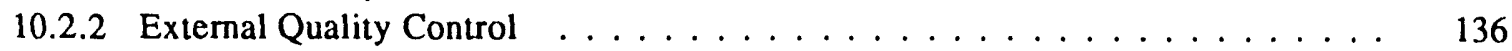

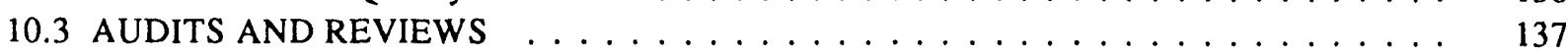

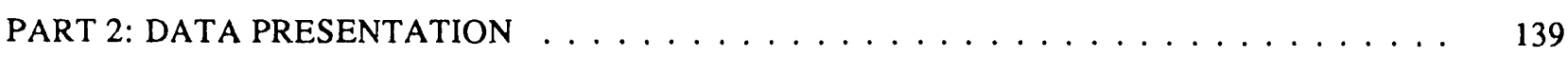

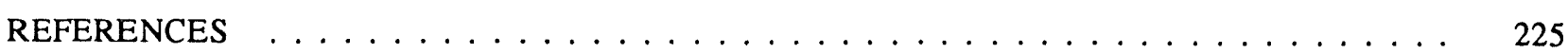

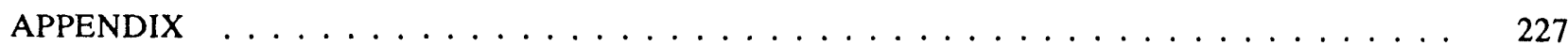




\section{ABBREVIATIONS, ACRONYMS, AND INITIALISMS}

\begin{tabular}{|c|c|}
\hline AAQS & Ambient air quality standard \\
\hline $\mathrm{ADI}$ & acceptable daily intake \\
\hline AMAD & activity median aerodynamic diameter \\
\hline APG & Analytical Products Group \\
\hline BMP & best management practices \\
\hline Btu & British thermal unit \\
\hline${ }^{\circ} \mathrm{C}$ & degrees celsius \\
\hline CAA & Clean Air Act \\
\hline $\mathrm{CDI}$ & calculated daily intake \\
\hline CFR & Code of Federal Regulations \\
\hline $\mathrm{Ci}$ & curie \\
\hline $\mathrm{cm}$ & centimeter \\
\hline $\mathrm{cm}^{2}$ & square centimeter \\
\hline $\mathrm{cm}^{3}$ & cubic centimeter \\
\hline $\mathrm{CMI}$ & corrective measures implementation \\
\hline CMS & corrective measures \\
\hline $\cos$ & closure option study \\
\hline $\begin{array}{l}\text { CPF } \\
{ }^{137} \mathrm{Cs}\end{array}$ & $\begin{array}{l}\text { carcinogen potency factor } \\
\text { cesium-137 }\end{array}$ \\
\hline CWA & Clean Water Act \\
\hline CWMO & Central Waste Management Office \\
\hline CX & categorical exclusion \\
\hline CY & calendar year \\
\hline$d$ & day \\
\hline $\mathrm{DCA}$ & dichloroethane \\
\hline DCE & dichloroethylene \\
\hline DCF & dose conversion factor \\
\hline DMR & Discharge Monitoring Report \\
\hline DOE & U.S. Department of Energy \\
\hline DOT & U.S. Department of Transportation \\
\hline EDE & effective dose equivalent \\
\hline EML & Environmental Measurements Laboratory \\
\hline EMSL-LV & Environmental Monitoring System Laboratory at Las Vegas \\
\hline EP & extraction procedure \\
\hline EPA & Environmental Protection Agency \\
\hline ERP & Environmental Restoration Program \\
\hline ES\&H & Environmental Safety and Health \\
\hline${ }^{\circ} \mathrm{F}$ & degrees Fahreheit \\
\hline FFA & Federal Facility Agreement \\
\hline FFCA & Federal Facility Compliance Agreement \\
\hline FIFRA & Federal Insecticide, Fungicide, and Rodenticide Act \\
\hline
\end{tabular}




\begin{tabular}{|c|c|}
\hline $\mathrm{ft}^{3}$ & cubic foot \\
\hline $\mathrm{g}$ & gram \\
\hline gal & gallon \\
\hline GCEP & Gas Centrifuge Enrichment Plant \\
\hline GDP & gaseous diffusion plant \\
\hline GWQA & groundwater quality assessment \\
\hline h & hour \\
\hline ha & hectare \\
\hline HASA & high-assay sampling area \\
\hline HAZWDDD & Hazardous Waste Development, Demonstration, and Disposal \\
\hline $\mathrm{HF}$ & hydrofluoric acid \\
\hline in. & inch \\
\hline IRIS & Integration Risk Information System \\
\hline IRM & interim remedial measure \\
\hline $\mathrm{kg}$ & kilogram \\
\hline $\mathrm{km}$ & kilometer \\
\hline $\mathrm{L}$ & liter \\
\hline $\mathrm{lb}$ & pound \\
\hline LCSG & Laboratory Controls and Standards Group \\
\hline LDR & land disposal restricted \\
\hline LLWDDD & Low-Level Waste Disposal Development and Demonstration \\
\hline $\mathrm{m}$ & meter \\
\hline $\mathrm{M}$ & million \\
\hline $\mathrm{m}^{3}$ & cubic meter \\
\hline $\mathrm{Ci}$ & microcurie \\
\hline $\mathrm{g}$ & microgram \\
\hline $\mathrm{mCi}$ & millicurie \\
\hline $\mathrm{MCL}$ & maximum concentration level \\
\hline $\mathrm{mL}$ & milliliter \\
\hline $\mathrm{mg}$ & milligram \\
\hline Mgd & million gallons per day \\
\hline mrem & millirem \\
\hline $\min$ & minute \\
\hline NIST & National Institute for Standards and Testing \\
\hline NEPA & National Environmental Policy Act \\
\hline NESHAP & National Emissions Standards for Hazardous Air Pollutants \\
\hline NIOSH & National Institute of Occupational Safety and Health \\
\hline NOAA & National Oceanographic and Atmospheric Admninistration \\
\hline NPDES & National Pollutant Discharge Elimination System \\
\hline NVLAP & National Voluntary Accreditation Program \\
\hline $\mathrm{OAC}$ & Ohio Administrative Code \\
\hline $\mathrm{O} \& \mathrm{G}$ & oil and grease \\
\hline OEPA & Ohio Environmental Protection Agency \\
\hline ORGDP & Oak Ridge Gaseous Diffusion Plant \\
\hline $\begin{array}{l}\mathrm{ORO} \\
234 \mathrm{mpa}_{\mathrm{Pa}}\end{array}$ & $\begin{array}{l}\text { Oak Ridge Operations } \\
\text { protoactinium- } 234 \text { molal }\end{array}$ \\
\hline PAT & proficiency analytical testing \\
\hline PCB & polychlorinated biphenyl \\
\hline $\mathrm{pCi}$ & picocurie \\
\hline PET & proficiency environmental testing \\
\hline PETC & Pittsburgh Energy Technology Center \\
\hline $\mathrm{pH}$ & hydrogen ion concentration \\
\hline $\begin{array}{l}\text { PORTS } \\
\text { ppb }\end{array}$ & $\begin{array}{l}\text { Portsmouth Gascous Diffusion Plant } \\
\text { parts per billion }\end{array}$ \\
\hline
\end{tabular}




$\begin{array}{ll}\text { ppm } & \text { parts per million } \\ \text { PTI } & \text { permit to install } \\ \text { PTO } & \text { permit to operate } \\ \text { QA } & \text { quality assurance } \\ \text { QC } & \text { quality control } \\ \text { RCRA } & \text { Resource Conservation and Recovery Act } \\ \text { RCW } & \text { recirculating cooling water } \\ \text { RFA } & \text { RCRA Facility Assessment } \\ \text { RfD } & \text { reference dose } \\ \text { RFI } & \text { RCRA Facility Investigation } \\ \text { RW } & \text { routine water } \\ \text { s } & \text { second } \\ \text { SARA } & \text { Superfund Amendments and Reauthorization Act } \\ \text { SF } & \text { slope factor } \\ \text { SDWA } & \text { Safe Drizking Water Act } \\ \text { SMCL } & \text { secondary maximum concentration level } \\ \text { SO2 } & \text { sulfur dioxide } \\ \text { SWMU } & \text { solid waste management unit } \\ 99 \text { Tc } & \text { techiletium-99 } \\ \text { TCA } & 1,1,1-t \text { richloroethane } \\ \text { TCE } & \text { trichloroethyiene } \\ \text { TCLP } & \text { toxicity characteristic leaching procedure } \\ 231 \text { Th } & \text { thorium-231 } \\ \text { iLD } & \text { thermoluminescent dosimeter } \\ \text { 1RCL } & \text { total residual chlorine } \\ \text { TSCA } & \text { Toxic Substances Control Act } \\ \text { TSS } & \text { total suspended solids } \\ 234 \text { U } & \text { uranium-234 } \\ \text { UF6 } & \text { uranium hexafluoride } \\ \text { USGS } & \text { U.S. Geological Survey } \\ \text { UST } & \text { underground storage tank } \\ \text { VOC } & \text { volatile organic compound } \\ & \end{array}$




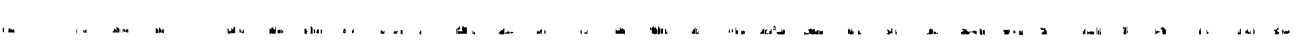




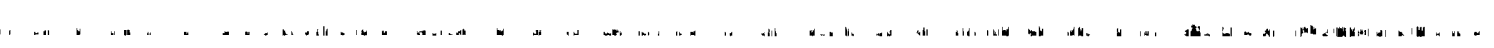




\section{INTRODUCTION}

\subsection{OPERATIONS OF THE PORTSMOUTH SITE}

This report presents environmental data and supporting narratives for the U.S. Department of Energy's (DOE's) Portsmouth Gaseous Diffusion Plant (PORTS) site Environmental Monitoring Program during 1990. Part 1 includes all narrative descriptions, summaries, and conclusions and is intended to be a "stand-alone" report for the reader who does not want to review in detail all of the 1990 data. Part 2 includes the detailed data summarized in a format that ensures that all environmental data are represented in the tables. Narratives are generally not included in Part 2.

PORTS is owned by DOE and is managed by Martin Marietta Energy Systems, Inc. The location of the plant site is shovin on the map of Ohio in Fig. 1.1. The facility is located in sparsely populated, rural Pike County, Ohio, on a $16.2-\mathrm{km}^{2}\left(6.3-\mathrm{mile}^{2}\right)$ site about $1.6 \mathrm{~km}$ (1 mile) east of the Scioto River Valley at an elevation approximately $36.6 \mathrm{~m}(120 \mathrm{ft})$ above the Scioto River floodplain. Figure 1.2 depicts the plant site and its immediate environs. The terrain surrounding the plant, except for the Scioto River noodplain, consists of marginal farmland and densely forested hills. The Scioto River floodplain is farmed extensively, particularly with grain crops.

The principal site process is the separation of uranium isotopes through gaseous diffusion. The gaseous diffusion process for uranium enrichment is based on the fact that lighter molecules diffuse slightly faster than heavier molecules through the walls of a poruus tube called a barrier. The portion of gas passing through the barrier wall is slightly richer in ${ }^{235} \mathrm{U}$. Support operations include the foed and withdrawal of material from the primary ficcess, treatment of water for both putable and cosling purposes, steam generation for heating purposes, decontamination of equipment remcred from the plant for maintenance or replacement, recovery of uranium from various waste materials, and treatment of industrial wastes.

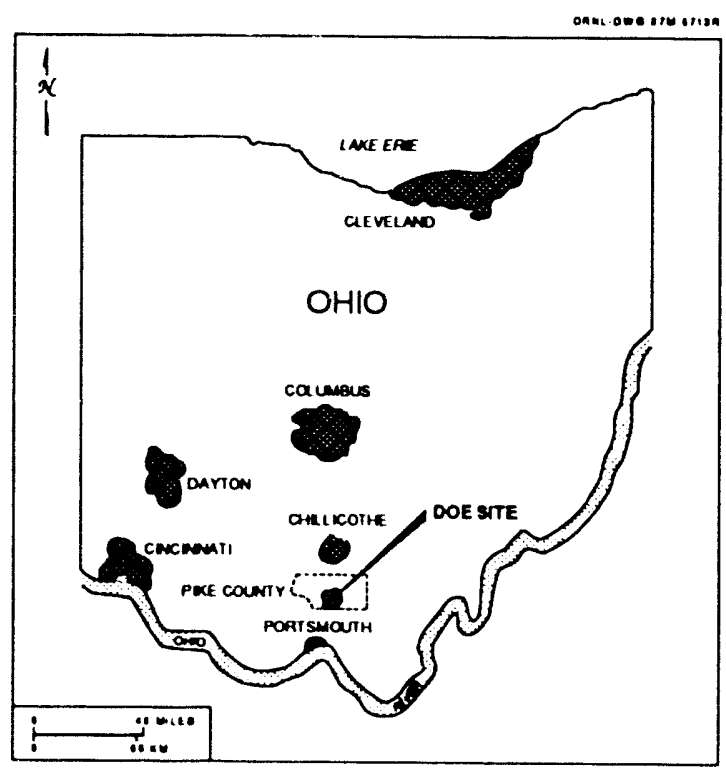

Fig. 1.1. Map showing the location of DOE's Installation in the state of Ohio.

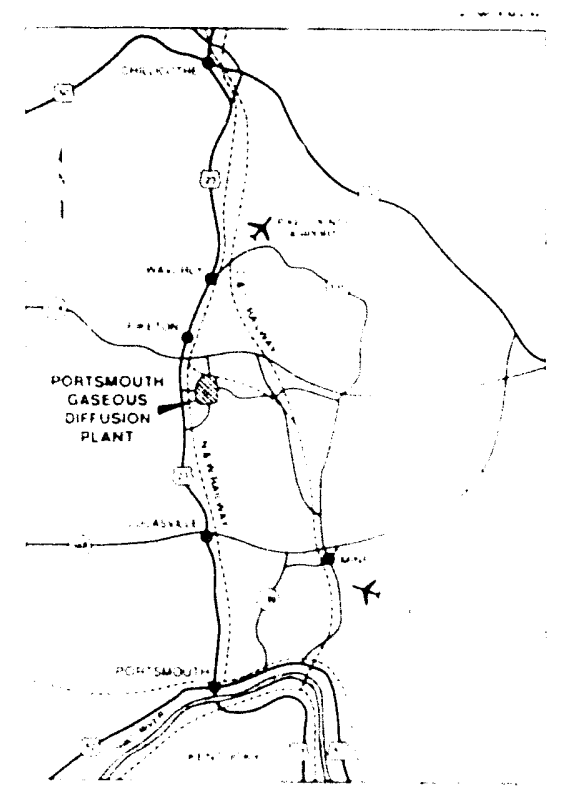

Fig. 1.2. Map showing the location of the Yortsmouth site in relation to the geographic region. 
Local tributaries flowing into the Scioto River are relatively unpolluted except for contamination introduced by agricultural nonpoint source runoff. PORTS discharges into Little Beaver Creek, Big Run Creck, two pipelines, and the west drainage ditch-all of which ultimately flow into the Scioto River (Fig. 1.5). The two pipelines carry the effluent from the sewage treatment plant and the treated blowdown from the recirculating cooling water (RCW) system. Sludge from the sewage treatment plant is discharged into a lagoon where the sludge settles and the supernatant water is recycled to the water treatment plant. Sludge from the RCW blowdown treatment plant is stabilized with lime and dewatered in a filter press. The other effluent streams contain primarily storm runoff and water used for once-through cooling purposes.

\subsection{REGIONAL DEMOGRAPHY}

Pike County has approximately 23,000 residents. Scattered rural development is typical; however, the county contains numerous small villages such as Piketon, Wakefield, and Jasper that lie within a few kilometers of the plant. The county's largest co nmunity, Waverly, is about $19 \mathrm{~km}$ (12 miles) north of the plant site and has a population of approximately 5100 residents. An estimate of the population distribution within an $8-\mathrm{km}$ (5-mile) radius of the plant is presented in Fig. 1.3, which shows a division of the area into sectors. The only residential center in this area is Piketon, which is about $8 \mathrm{~km}$ (4.97 miles) north of the plant on U.S. Route 23; its 1986 population was 1900 . Several residences are adjacent to the southern half of the eastern boundary and along the Wakefield Mound Road (Old U.S. 23) directly west of the plant. Two nursing homes with a combined capacity of 60 persons are located along Wakefield Mound Road.

Additional population centers within $80 \mathrm{~km}$ (50 miles) of the plant are Portsmouth (population 25,500), $43 \mathrm{~km}$ (27 miles) south; Chillicothe (population 23,420), $43 \mathrm{~km}$ (27 miles) north; and Jackson (population 6,675), $29 \mathrm{~km}$ (18 miles) east. The total population of the area lying within an $80-\mathrm{km}$ (50-mile) radius of the plant is approximately 600,000 .

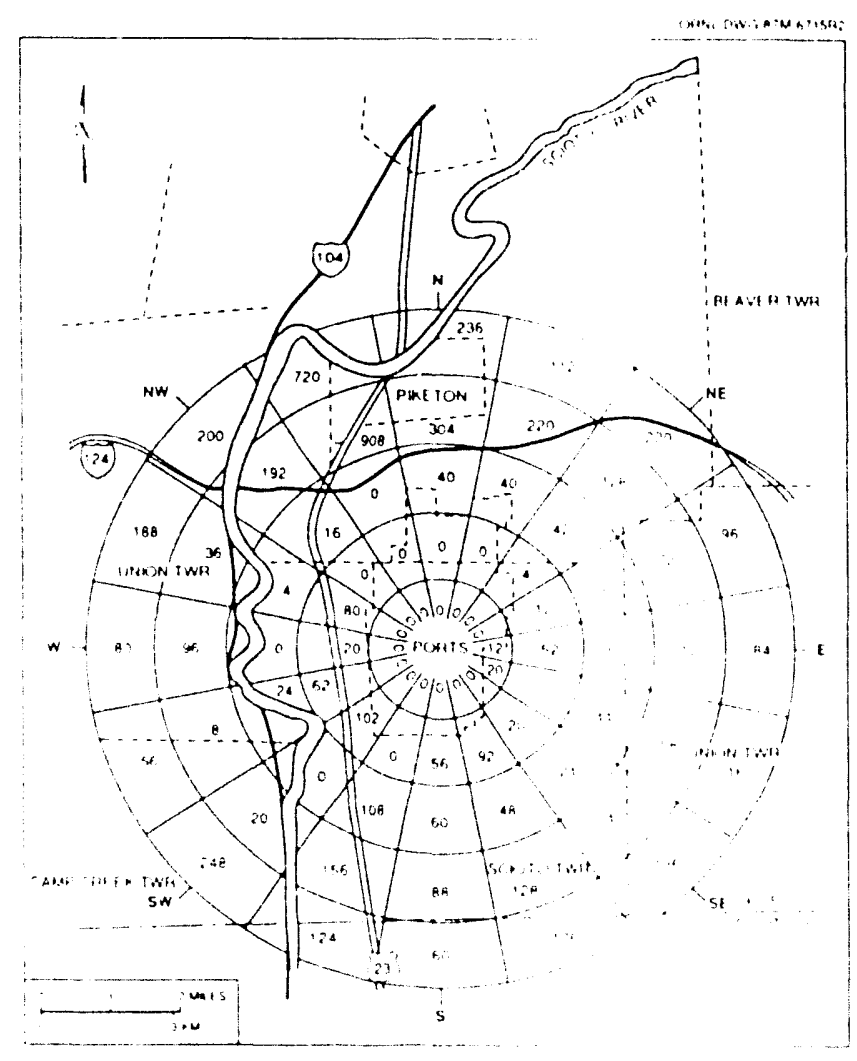

Fig. 1.3. Population distribution in an $8 \cdot \mathrm{km}(5-\mathrm{mile})$ radius. 


\subsection{GEOLOGY AND GROUNDWATER}

\subsubsection{Geologic History}

The site is located within the Appalachian Plateau physiographic province near its northwestern boundary. The uppermost rock units in this region were deposited in an inland sea during the Paleozoic era. At the end of the Paleozoic era (230 million years ago), the region was uplifted and gently folded to form a shallow basin that trends parallel to the Appalachian Mountains. Subsequent erosion of the uplifted sediments produced the deeply dissected, knobby terrain that characterizes the region today.

During the Quaternary period (1 million years ago), continental glaciation spread from a base near Hudson Bay to as far south as Chillicothe, Ohio (see Fig. 1.4). These glaciers indirectly influenced conditions south of this boundary and altered drainage patterns. The major surface : ater body in the region prior to glaciation was the northerly flowing Teays River. A major tributary of this river, the Portsmouth River, flowed northward through the area now occupied by the plant site and joined the
Teays River near Piketon. During the Pleistocene age the Teays River was dammed at a point north of the site (presumably by another glacial event). This formed a large lake named Lake Tight. Alluvium deposited in the Teays and Portsmouth River valleys and lacustrine material deposited within Lake Tight are represented in the Teays Formation, which unconformably overlies the Palcozoic units in the site area.

Modification to the regional drainage system occurred as Lake Tight filled to the south and sought another drainage outlet. Thus the Newark River rose and flowed southwestwardly from Chillicothe to Portsmouth where it joined the Cincinnati River, which flowed through the valley now occupied by the Ohio River. The Newark River was a major channel for alluvium-bearing meltwater from the Pleistocene continental glaciations. The deep Newark River valley was partially filled with sand, silt, and gravel outwash from the north; this was deposited unconformably over the clay unit formerly deposited by Lake Tight.

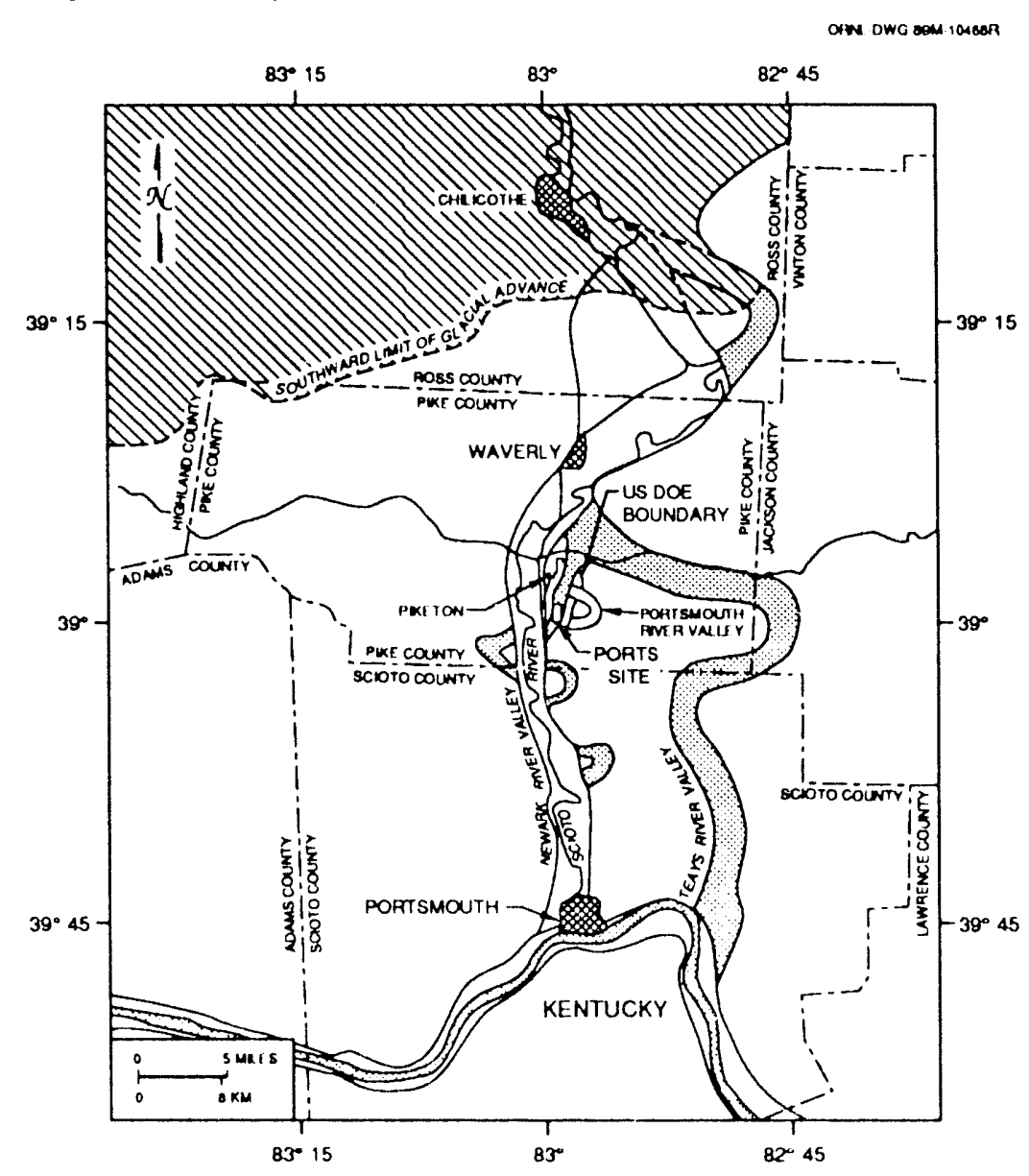

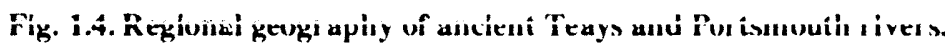




\subsubsection{Geology}

The geology of the site vicinity, like that of the region, is dominated by the Palcozoic shales and sandstones that are unconformably overlain by unconsolidated Pleistocene fluvial and lacustrine deposits. Fill deposited by humans and recent alluvium and colluvium are locally present also.

The Mississippian Waverly Group crops out near the site and dips gently to the east; minor exposure of this material is present on the plant. Because the Waverly Group and unconsolidated Pleistocene strata comprise the near-surface materials most likely to be affected by waste disposal operations, they have been studied more extensively than other strata. In ascending order the Waverly Group consists of the Bedford Shale, Berea Sandstone, Sunbury Formation, Cuyahoga Formation, Logan Formation, and the Maxville Limestone. The latter two units are not present at PORTS and are not discussed here.

The Bedford Shale is about $100 \mathrm{ft}$ thick and is composed of thinly bedded shale with interbeds and lamination of hard, gray, fine-grained sandstone and silt. The Berea Sandstone underlies the unconsolidated sediments in the western half of the plant site. This formation, a fine-grained sandstone with thin shale beds, is approximately $8 \mathrm{~m}(26 \mathrm{ft})$ thick. The Sunbury Shale overlies the Berea Sandstone and underlies the unconsolidated sediments along the castern half of the PORTS site. It is highly carbonaccous black shale approximately $6 \mathrm{~m}$ (20) ft) thick. The Cuyahoga Shale forms the hills east and west of the plant and underlies the unconsolidated deposits at X-735 Sanitary Landfill. The Cuyahoga consists of gray thinly bedded shale with occasional lenses of fine grained sandstone. The Cuyahoga has been partially eroded in this area and reaches a local thickness of about $160 \mathrm{fect}$.

The plant site is located in the abandoned valley of the Portsmouth River, a tributary of the ancient Teays River. The ancestral river valley is filled with Pleistocene fluvial and lacustrine deposits. As much

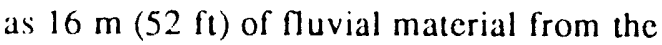
Portsmouth River system and lacustrine material from Lake Tight unconformably overlic the Waverly Group. The most common sequence of unconsolidated strata in the buried Portsmouth River valley consists of a thin layer of silty sand and gravel (representing fluvial deposition) overlain by a thicker layer of lacustrine fine sand, silt, and clay.
These unconsolidated near-surface sediments at the plant site comprise the Teays Formation; it has two members- the Gallia Sand and the Minford Clays. The Gallia Sand is the basal unit, and its contact with the underlying bedrock is sharp. The Gallia Sand at the facility consists of sands and gravels, varies in thickness from 0 to $3 \mathrm{~m}(0$ to $10 \mathrm{ft})$, and is usually found at depths ranging from 6 to $9 \mathrm{~m}$ (20 to $30 \mathrm{ft}$ ). Overlying the Gallia Sand is the Minford Clay; this varies in thickness from 0 to $12 \mathrm{~m}$ (0 to $39 \mathrm{ft}$ ) at the site.

\subsubsection{Regional Groundwater Conditions}

The availability, quantity, and quality of groundwater at any location are controlled by the geologic conditions beneath the surface of the land and a variety of other factors including topography, recharge arca, rainfall, infiltration characteristics of the soil, existing uses, and existing sources of groundwater pollution. Sand and gravel deposits may store and transmit sizable quantities of water. Clay, silt, and shale may contain as much water per cubic meter as sand and gravel; however, the water is held in pores so small that it generally cannot be transmitted in usable quantities. Water yiclds in limestone or sandstone depend upon the particular nature of the formation being examined (c.g., grain size, fractures, joint bedding planes, etc.).

Geologic units that occur near the surface in Pike County form two general classes: (1) consolidated layers of limestone, shale, and sandstone and (2) unconsolidated alluvial deposits of sand, gravel, clay, and silt. Eastem Pike County is underlain by Mississippian age sandstone and shale formations that normally do not yicld enough water for domestic use. Actual yiclds from wells developed in these sandstone and shale formations depend on the presence of fractures and bedding planes and can vary widely over comparatively short distances.

The unconsolidated alluvial deposits are found in the old Teays River valley and its tributaries, including the Portsmouth and Newark River valleys. The primary source of groundwater in Pike County is the alluvial deposits in the former Newark River valley. These deposits consist of interbedded layers of sand and gravel bencath recent silt deposits and range from 18 to $30 \mathrm{~m}$ (59 to $98 \mathrm{ft}$ ) thick. Large supplies of groundwater are available from the alluvium and outwash because of the thickness of the 
sand and gravel and its proximity to the Scioto River. Pumping from wells near the river induces infiltra'in from the river into the gravels supplying the wells.

The Teays River valley from Beaver to Piketon is partially filled with clay, silt, sand, and fine gravel. The alluvium is thinnest in the western portion of the valley and thickens to the east in the vicinity of Beaver. The most productive sources of groundwater in this valley are located near the village of Beaver and in the lower portion of Beaver Creek valley where a layer of fine sand and gravel is encountered above the bedrock surface. Elsewhere, the alluvium is primarily silt and clay with occasional lenses of sand and gravel on top of the shale bedrock. Water supplies in these areas are meager unless one of these lenses is encountered. Underlying both the Newark and Teays valleys is shale bedrock that, unless fractured, yields virtually no water. Regional groundwater flow is north to south, primarily along the sand and gravel deposits within the old Newark River valley.

\subsubsection{Site Groundwater Conditions}

Two aquifers or aquifer types can be distinguished at the PORTS site: (1) the bedrock aquifer consisting of shallow Mississippian shales and sandstones, (2) the unconsolidated deposits adjacent to the Scioto River and other unconsolidated deposits. The latter two aquifer types have similar characteristics and properties; thus they can be described as a single aquifer system.

The bedrock aquifer includes the Cuyahoga Shale, Sunbury Shale, Berea Sandstone, and Bedford Shale. Near the top of the bedrock surface, permeabilities of these units are mostly the result of fractures. Based on analysis of well yields for bedrock wells located near the site vicinity, no significant difference is evident in permeability between shale and sandstone units. As depth increases, fractures influence overall permeability to a decreasing extent, and porosity, grain shape, and packing arrangement exert a greater influence on permeability. At greater depths the Berea Sandstone is probably more permeable than the shale units, which would act as confining layers. No well-defined lower limit to the bedrock aquifer exists, but because pumping costs increase and because permeability decreases with depth, only the shallow portions of the bedrock aquifer have been exploited in the site vicinity. The depth to bedrock in the site vicinity varies from near zero on hilis and ridges to about $16 \mathrm{~m}(52 \mathrm{ft})$ in the lowlands. In some parts of the Scioto River valley, the depth to bedrock is greater than $32 \mathrm{~m}$ (104 ft).

The Scioto River Aquifer System consists of a thick, coarse-grained glacial outwash deposit overlain by finer-grained modern alluvium. The Scioto River Aquifer is the most productive aquifer; its thickness ranges up to about $32 \mathrm{~m}$ (104 ft). This aquifer is interconnected with other unconsolidated aquifers of ancestral river systems, Portsmouth River and Teays River, and with minor unconsolidated deposits associated with existing streams. The grain size and hydraulic conductivity are smaller in tributary valleys than in the Scioto River valley. In general, these aquifers extend long distances along the stream valleys, but their width and thickness are limited by the sides and bottoms of the valley they occupy.

Alluvial aquifers may be recharged by, or discharged to, the streams that occupy their valleys. Highs in the potentiometric surface (an imaginary surface representing the total head of groundwater in an aquifer that is defined by the level to which the water will rise in a well) generally correspond to topographic high points, and lows generally occur beneath low points in the ground surface. This indicates that alluvial groundwater flows toward, and discharges to, hydraulic boundaries such as ponds and streams that occur at low elevations.

In general, groundwater in the northern part of the site flows toward Little Beaver Creek. In the vicinity of $X-701 B$, it flows castward toward the creek. Little Beaver Creek eventually discharges into Big Beaver Creek. The flow direction at X-616 is westward toward a small, unnamed, intermittent tributary of the Scioto River. Subsurface flow at $\mathrm{X}-749$ is divided between a westward component and an eastward component conforming to the upper reaches of the Big Run drainage basin. The upper tributaries of the Big Run drain the area of X-231B. Groundwater flow in this flat area is probably toward the south. 


\subsection{TOPOGRAPHY AND SURFACE WATER}

\subsubsection{Regional Drainage}

The DOE site lies within the Scioto River drainage basin, the second largest in Ohio. Both groundwater and surface water are drained from the plant site by a network of tributaries of the Scioto and Ohio rivers. A U.S. Geological Survey (USGS) gauging station is located at Higby, which is just north of the county line between Pike and Ross counties. The Scioto River flows measured at Higby from 1930 to 1973 range from $5310 \mathrm{~m}^{3} / \mathrm{s}$ $\left(187,550 \mathrm{ft}^{3} / \mathrm{s}\right)$ to $7.32 \mathrm{~m}^{3} / \mathrm{s}\left(260 \mathrm{ft}^{3} / \mathrm{s}\right)$ and average $133 \mathrm{~m}^{3} / \mathrm{s}\left(4700 \mathrm{ft}^{3} / \mathrm{s}\right)$. The estimated 7-day, 10 -year low-flow discharge at Higby is $8.58 \mathrm{~m}^{3} / \mathrm{s}\left(303 \mathrm{ft}^{3} / \mathrm{s}\right)$. The USGS has also measured extremes, averages, and daily concentrations of chemical contaminants, particle size, distribution of suspended sediment, water temperature, dissolved oxygen, specific conductance, suspended sediment discharge, and radiochemical contaminants at Higby, which is upstream of the gascous diffusion facilities, and at a recording station at Lucasville, which is downstream. Those data have been published (USGS 1986).

\subsubsection{Site Topography}

The predominant landform in the site arca is the relatively level, broad, filled valley of the preglacial Portsmouth River. The valley is oriented north to south and is bounded on the east and west by ridges or low-lying hills that have been deeply dissected by present and past drainage features. These ridges consist of Mississippian age formations of Sunbury and Cuyahoga shales. Another significant landform is the small valley formed by Little Beaver Creck; this creck flows in a northwesterly direction across the middle of the DOE property just north and east of the main plant area (sec Fig. 1.5).

Other significant landforms consist of several small valleys formed by streams that have cut into the relatively level lake and river deposits of the Portsmouth River valley and (in some areas) into the Portsmouth River valley floor. One of these valleys is that of a northwestward-flowing stream near the west-central area of plant site whose valley has been significantly altered by grading in the area. Two more streams are located in the southern portion of the plant area. In the southeast portion of the site, the southerly flowing stream named Big Run Creek is situated in a relatively broad, gently sloping valley where significant deposits of recent alluvium have been laid down by the stream. An unnamed southerly and westerly flowing stream in the southwest portion of the site has formed a narrow, steep-walled valley with relatively little recent alluvium. The Mississippian rocks are exposed to a greater extent here than in the eastern valley created by Big Run Creck.

\subsubsection{Site Drainage}

The PORTS site is drained by several small tributaries of the Scioto River (see Fig. 1.5). The largest stream on the plant property is Little Beaver Creck, which drains the northern and northeastern portions of the site before discharging into Big Beaver Creck (see Fig. 1.6). Upstream of the plant, Little Beaver Creek has intermittent flow throughout the year. On-site, Little Beaver Creek received treated process wastewater from the $\mathrm{X}-701 \mathrm{~B}$ holding pond via the east drainage ditch (until November 1988 when waste streams were stopped from entering the $\mathrm{X}-701 \mathrm{~B}$ pond) and stormwater runoff from the northwestern and northern portions of the plant via several storm sewers, watercourses, and the north holding pond. Shortly after leaving the reservation, Little Beaver Creck flows into Big Beaver Creck, which also receives runoff from the northeastern portion of the plant directly. Big Beaver Creck flows to the Scioto River.

Storm sewers on the south end of the plant site discharge to the south holding pond, which overflows to Big Run Creek, another intermittent stream. A small, unnamed, intermittent watercourse drains the southwest corner of the facility via the southwest holding pond. Farther north on the property is another intermittent watercourse that receives runoff from the central and western portions of the site via the west drainage ditch. All of these streams flow directly to the Scioto River and carry only stormwater runoff.

\subsection{BIOTA}

Pike County consists primarily of farmland (including cropland, woodlot, and pasture) and forest (including Pike State Forest and portions of Wayne National Forest); urban and suburban areas (ccupy 


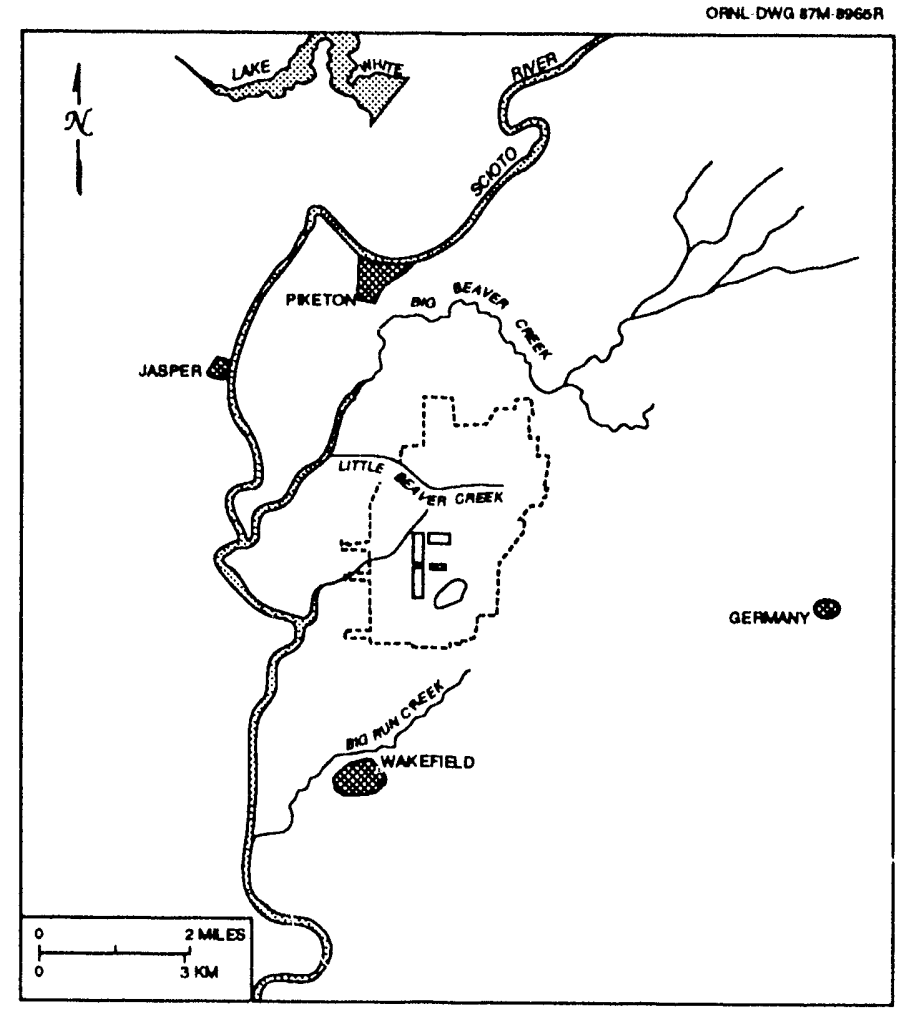

Fig. 1.5. Location of surface water bodies on and in the vicinity of the PORTS site.

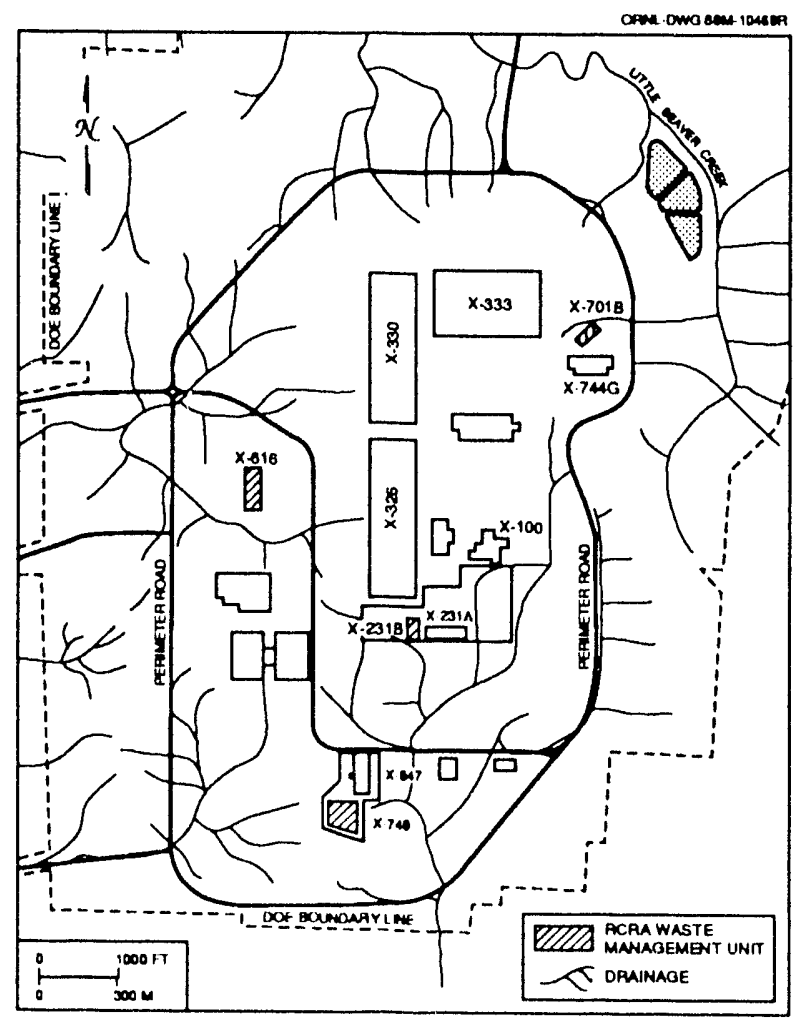

Fig. 1.6. Local drainage. 
about $1 \%$ of the total land area. Figure 1.7 shows the land use within an 8-km (5-mile) radius of the plant.

The croplands lie mostly on or adjacent to the Scioto River floodplain and are farmed intensively, particularly with grain crops such as corn and soybeans. Other produce such as tomatoes, cabbage, and fruits are also cultivated in the area. Hillsides and terraces are more commonly used for cattle pasture. Both dairy and beef cattle are raised in the area of the Portsmouth site. Other farm animals such as horses, pigs, sheep, goats, and chickens are raised to a lesser extent. Commercial woodlands (excluding sapling-seedling stands) are predominately sawtimber stands; pole-timber stands are of lesser proportion.

About 9,890 ha $(24,430$ acres $)$ of farmland (including cropland, woodlot, and range pasture) and 9,885 ha $(24,416$ acres $)$ of forest lie within an $8-\mathrm{km}$ (5-mile) radius of the plant. There are also $206 \mathrm{ha}$ (510 acres) in urban areas within the same distance. The distribution of forest property in Pike County is similar to that of surrounding counties. Pike County is also typical from the standpoint of productivity.
Land use is important in determining the impact of plant operations.

The vegetation of Pike County has been classified into three major forest types including mixed-mesophytic (upland mixed hardwoods), mixed oak (oak-hickory), and bottomland hardwoods.

The upland hardwoods areas include green ash, northern red oak, tulip poplar, red maple and several additional species. The oak-hickory areas include white oak, northern red oak, post oak, shagbark hickory, pignut hickory, and various other associated species. The bottomland hardwoods areas include sycamore, sugar maple, flowering dogwood, and American beech, as well as other less important species.

All of the forest types represented are second-growth forest. A number of areas that once were cleared have been allowed to lie fallow for several years and are now in various stages of succession. Several small plantations of pines are located on the reservation and several small wetland areas have developed around holding ponds and in ditch lines.

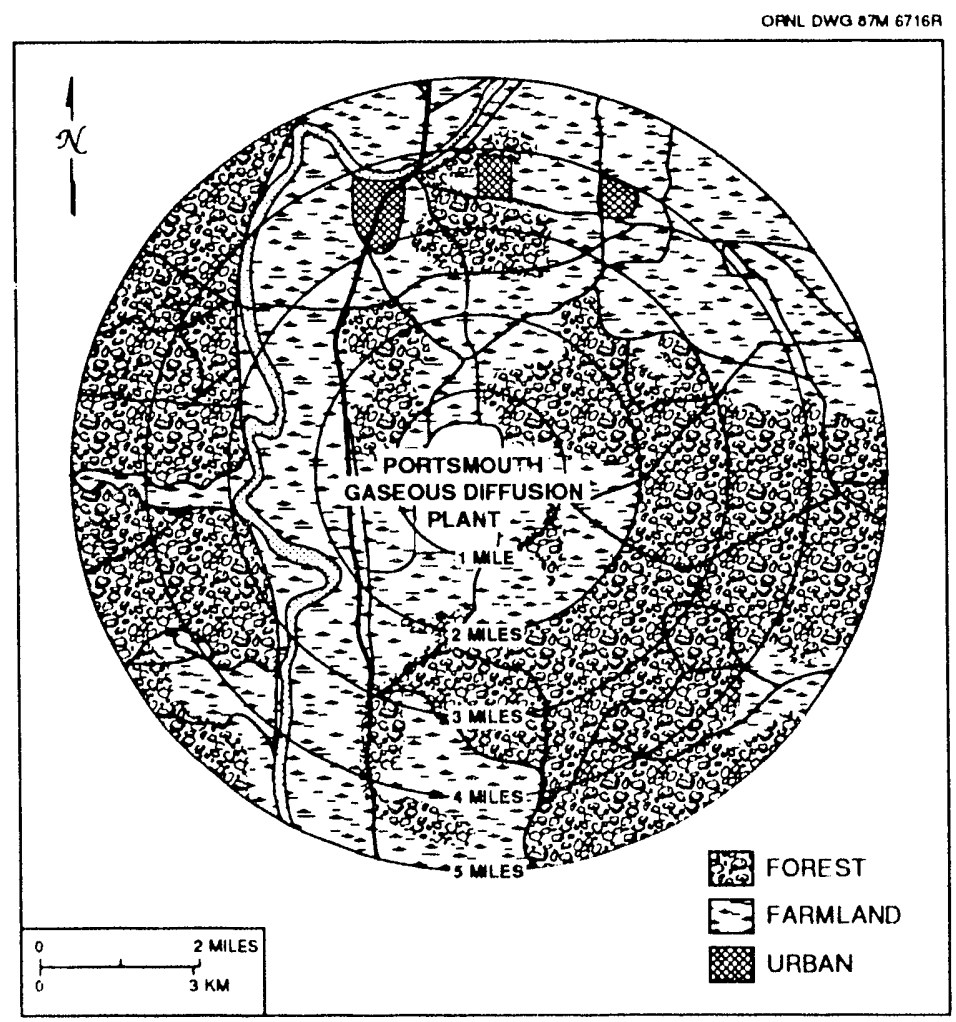

Fig. 1.7. Land use within $8 \mathrm{~km}$ (5 miles) of PORTS. 
The area within the security fence is a fully developed industrial area. The grounds surrounding buildings and other fixtures are maintained as lawns and support various species of grasses and herbaceous dicots that are mowed periodically throughout the growing season.

No unique vegetation types exist within the boundaries of the reservation, and no threatened or endangered species of plants are known to be present on the site.

The fauna of the PORTS facility includes mammals, birds, amphibians, fish, and reptiles, as well as several invertebrate phyla.

Forty-nine mammals have ranges that include the plant site. Of these, 22 actually have been observed on site. The most abundant mammal species on site are the white-footed mouse and the short-tailed shrew. Large mammals include eastern cottontail rabbit, white-tailed deer, opossum, and woodchuck. In addition, the eastern chipmunk, fox and gray squirrel, northern flying squirrel, and long-tailed weasel are known to be present on the site.

One hundred and sixteen bird species have been observed within the boundaries of the plant reservation. These include year-round residents, winter residents and migratory species. Ninety-nine species of birds are known to breed within the political boundaries of Pike County. Any of these species is likely to be found on the plant site.

Twenty-eight species of reptiles and thirty species of amphibians have ranges that include the plant site. Nine species of reptiles and six species of amphibians have been observed on the reservation. The most common species of reptiles are the eastern box turtle, black rat snake, and northern black racer. The most common species of amphibians are the American toad and the northern dusky salamander.

Fifty-eight species of fish are found in streams in the immediate vicinity of the plant.

Several invertebrate phyla are represented on the plant site, with the arthropods having the greatest diversity. Approximately 500 species of insects representing 12 orders have been identified from terrestrial habitats. In addition, representative taxa of macroinvertebrates from various phyla, including Annelida, Arthropoda, Nematoda, Mollusca, and Platyhelminthes, have been observed in streams or terrestrial habitats either through casual observation or during sampling activities.
Three of the species of mammals whose ranges include the plant site are on either the U.S. or Ohio endangered species lists. These include the Indian myosotis (a bat found in limestone caves, federal endangered species), the river otter (Ohio endangered species), and the eastern woodrat (Ohio endangered species). In addition, Rafinesque's big-eared bat is an endangered species with a range peripheral to the reservation. None of these species has been found on the plant site, and no habitats suitable to support populations of these species have been discovered on the reservation.

Sharp-shinned hawks (Ohio endangered species) have been sighted on occasion. A population of the aquatic plant Saggitaria australis (Ohio threatened species) is located just north of the plant site. No other federal or Ohio recognized endangered or threatened species of plants or animals are known to be in the vicinity of the PORTS reservation.

\subsection{CLIMATE}

Pike County has a generally moderate climate. The National Oceanic and Atmospheric Administration maintained a weather station (temperature and precipitation only) in Waverly about $16 \mathrm{~km}$ (10 miles) north of the plant from 1889 until the early 1980s. An on-site station operated by the Portsmouth Emergency Preparedness Department has monitored air temperature; humidity; and wind direction, speed, and stability at both $10-\mathrm{m}(32.8-\mathrm{ft})$ and $40-\mathrm{m}(131.2-\mathrm{ft})$ levels (as well as solar radiation, precipitation, and soil temperatures at ground level) since December 1983.

Winters in Pike County are moderately cold. On the average, there are $112 \mathrm{~d} /$ year at or below $32^{\circ} \mathrm{F}$ $\left(0^{\circ} \mathrm{C}\right)$ but only $3 \mathrm{~d} /$ year below $0^{\circ} \mathrm{F}\left(-17.8^{\circ} \mathrm{C}\right)$. Summers are moderately warm and humid [i.e., an average of $27 \mathrm{~d} /$ year at or above $\left.90^{\circ} \mathrm{F}\left(32.2^{\circ} \mathrm{C}\right)\right]$. Annual precipitation averages $39.8 \mathrm{in}$. $(101.1 \mathrm{~cm})$. The precipitation is usually well distributed, fall being the driest season. Average annual snowfall at Waverly is 20.4 in. $(51.8 \mathrm{~cm})$.

Prevailing winds at the site are out of the southwest to south. Average wind speeds are about $5 \mathrm{mph}(8 \mathrm{~km} / \mathrm{h})$, although winds of up to $75 \mathrm{mph}$ $(120 \mathrm{~km} / \mathrm{h})$ have been recorded at the plant site. Usually, high winds are associated with thunderstorms that occur in spring and summer. 
Daytime wind stabilities are most commonly class D (neutral) followed by class $\mathrm{C}$ (slightly unstable). Nighttime winds are predominately class $\mathrm{F}$ (moderately stable). Southern Ohio is within the midwestern tornado belt. No tornados have struck the plant site to date. 


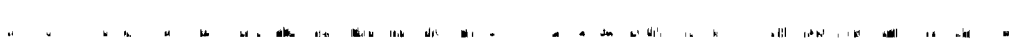




\section{AIRBORNE DISCHARGES, AMBIENT AIR MONITORING, METEOROLOGICAL MONITORING, AND EXTERNAL GAMMA RADIATION}

The air-related environmental programs at PORTS are the Emission Monitoring and Control Programs, the Ambient Air Monitoring Program, the Meteorological (Weather) Monitoring Program, and the External Gamma Radiation Program (described in Subsects. 2.1, 2.2, 2.3, and 2.4, respectively). Each section is divided into two units: the first describes each program; the second summarizes and interprets the data collected by that program in 1990 .

Subsect. 2.5 summarizes the overall findings and conclusions. A more detailed presentation of the data without discussion is given in Part 2 of this report. The potential dose to members of the public (including that from airborne discharges) is summarized and discussed in Sect. 7.

As of December 31, 1990, the Ohio Environmental Protection Agency (OEPA) has issued Permits To Operate (PTO) for the 10 sources listed in Table 2.1 and has placed an additional 81 small sources on registration status in licu of issuing permits. Two more sources have been issued Permits To Install (PTI) with PTOs still pending. In past years, Ohio industries and OEPA have commonly permitted only major and significant minor air emission sources, although this was not in strict accordance with the Ohio regulations. OEPA has recently announced that it will no longer operate in this manner, and PORTS is in the process of permitting all air emission sources in the plant. In March 1990, 429 PTO applications and 95 PTI applications were filed for 429 small air emissions sources. (Most small air sources at PORTS predate the PTI regulations and are thus exempted.) An additional 6 PTO and 5 PTI applications were filed subsequently. At the end of 1990 , a total of 445 PTO applications and 99 PTI applications were still pending with OEPA.

\subsection{EMISSION MONITORING}

This subsection briefly describes major air emission sources and associated emission control and emission-monitoring systems at PORTS. A summary of the total annual emissions and a discussion of the significance of the data and of any anomalies follow.

\subsubsection{Description of Emission Sources and Monitoring Systems}

Three emission-monitoring systems are in place at PORTS, each of which monitors a different class of airborne emissions. In addition, several types of airborne emissions are calculated from process data or purchasing records.

\subsubsection{Gaseous radionuclide and fluoride emissions}

Gascous radionuclide and fluoride emissions from the purge cascade vents, the cold recovery and wet air evacuation vents, the $\mathrm{X}-345$ high-assay sampling area (HASA) vent, the $\mathrm{X}-344$ evacuation vent, and the $X-333$ seal exhaust vent are sampled continuously by systems developed and built by the PORTS plant laboratory. Additional samplers for the five remaining seal exhaust vents are planned for 1991. Together these vents account for virtually all of the radionuclide and most of the fluoride emissions from PORTS. The "continuous vent samplers" draw a flow-proportional sample of the vent stream through two small alumina traps in series via an isokinetic probe. Routinely, the primary sample traps are replaced weckly, and the secondary traps are replaced quarterly.

Radionuclides known to be present are the isotopes ${ }^{234} \mathrm{U},{ }^{235} \mathrm{U}$, and ${ }^{238} \mathrm{U}$; the two trace impurities from recycled uranium ${ }^{236} \mathrm{U}$ and ${ }^{99} \mathrm{Tc}$; and equilibrium 
Table 2.1. Air permits issued by the Ohlo Environmental Protection Agency

\begin{tabular}{cll}
\hline Number & Building & \multicolumn{1}{c}{ Description } \\
\hline B001 & X-600 & Coal-fired boiler (No. 1-south) \\
B002 & X-600 & Coal-fired boiler (No. 2-middle) \\
B003 & X-600 & Coal-fired boiler (No. 3-north) \\
P010 & X-700 & Solvent contaminated water treatment system \\
& & (air stripper) \\
L005 & X-700 & Vapor degreaser \\
L002 & X-720 & Compressor shop vapor degreaser \\
P018 & X-720 & Motor shop burn-off oven \\
L001 & X-720 & Motor shop vapor degreaser \\
F001 & X-735 & Refuse/asbestos handling \\
F002 & X-735 & Roads/parking areas landfill \\
\hline
\end{tabular}

concentrations of short-lived uranium daughters. Fluo ides are present as various reactive fluoride gases including $\mathrm{UF}_{6}$ and HF. Alumina from the sampler is analyzed for total uranium, ${ }^{235} \mathrm{U}$, technetium, and total fluorides. The ${ }^{235} \mathrm{U} /$ total uranium ratio (i.e., the "assay") and process data are used to calculate the fractions of ${ }^{234} \mathrm{U}$ and ${ }^{236} \mathrm{U}$ in the emissions. Because of their short half-lives, uranium daughter emissions cannot be reliably measured in weckly samples and are assumed to be in equilibrium with their parent nuclides. The uranium daughters included in the equilibrium calculations are ${ }^{234} \mathrm{Th}$, ${ }^{231} \mathrm{Th}$, and ${ }^{234 \mathrm{~m}} \mathrm{~Pa}$.

The purge cascades use gascous diffusion to separate $U_{6}$ continuously from light gases (primarily air) that have leaked into or otherwise entered the process. The $\mathrm{UF}_{6}$ is returned to the main cascade, and the "lights" are passed through activated alumina traps to remove residual traces of $\mathrm{UF}_{6}$ and other pollutants before sampling and venting to the atmosphere. PORTS uses two purge cascades known as the side-purge cascade and the top-purge cascade. Both cascades are exhausted by dedicated air jets ( $T$-jet and S-jet) or a standby air jet (E-jet) that can be valved in to replace temporarily or to supplement either of the regular air jets. All three jets are sampled by separate continuous samiplers. The purge cascades account for the bulk of the rovitine radionuclide emissions from the cascade.

The cold recovery and wet air evacuation systems are maintenance support systems in the X-330 and X-333 process buildings (see Fig. 2.1). Cold recovery systems are used to evacuate gases from cascade cells that must be opened for maintenance. Refrigerated "cold traps" are used to freeze out $\mathrm{UF}_{6}$, and noncondensable "lights" are passed through sodium fluoride traps and vented to atmosphere. After maintenance, the wet air evacuation systems evacuate outside (i.e., "wet") air through alumina traps before the cell is returned to service. In X-330, both systems exhaust through a common roof vent with a single sampler. In X-333, the two systems have separate roof vents and samplers. Normally, these systems are minor emission sources, but a potential for unplanned relcases exists.

Another emission source currently in the continuous vent sampler system is the X-345 HASA where cylinders of enriched $U_{6}$ are heated and sampled for quality control. To prevent sample mixing, the sampling manifold must be purged and evacuated after each set of samples. The evacuated gases are cold-trapped to recover residual uranium and vented through alumina traps. In addition, there is a suction device (i.c., a "gulper") behind the sample cylinders to collect any small releases during cylinder disconnects. The combined exhaust from both systems is sampled by a single continuous sampler. Routine emissions from the HASA are small, but because the system handles liquid $\mathrm{UF}_{6}$ of high assay, a potential exists for a significant unplanned release from this vent. The X-344 facility also heats cylinders of $U_{6}$ either for sampling or for transfer between cylinders. Like the X-345 HASA, there is a combined vent for system evacuation and for a "gulper" that is monitored by a single continuous sampler. 


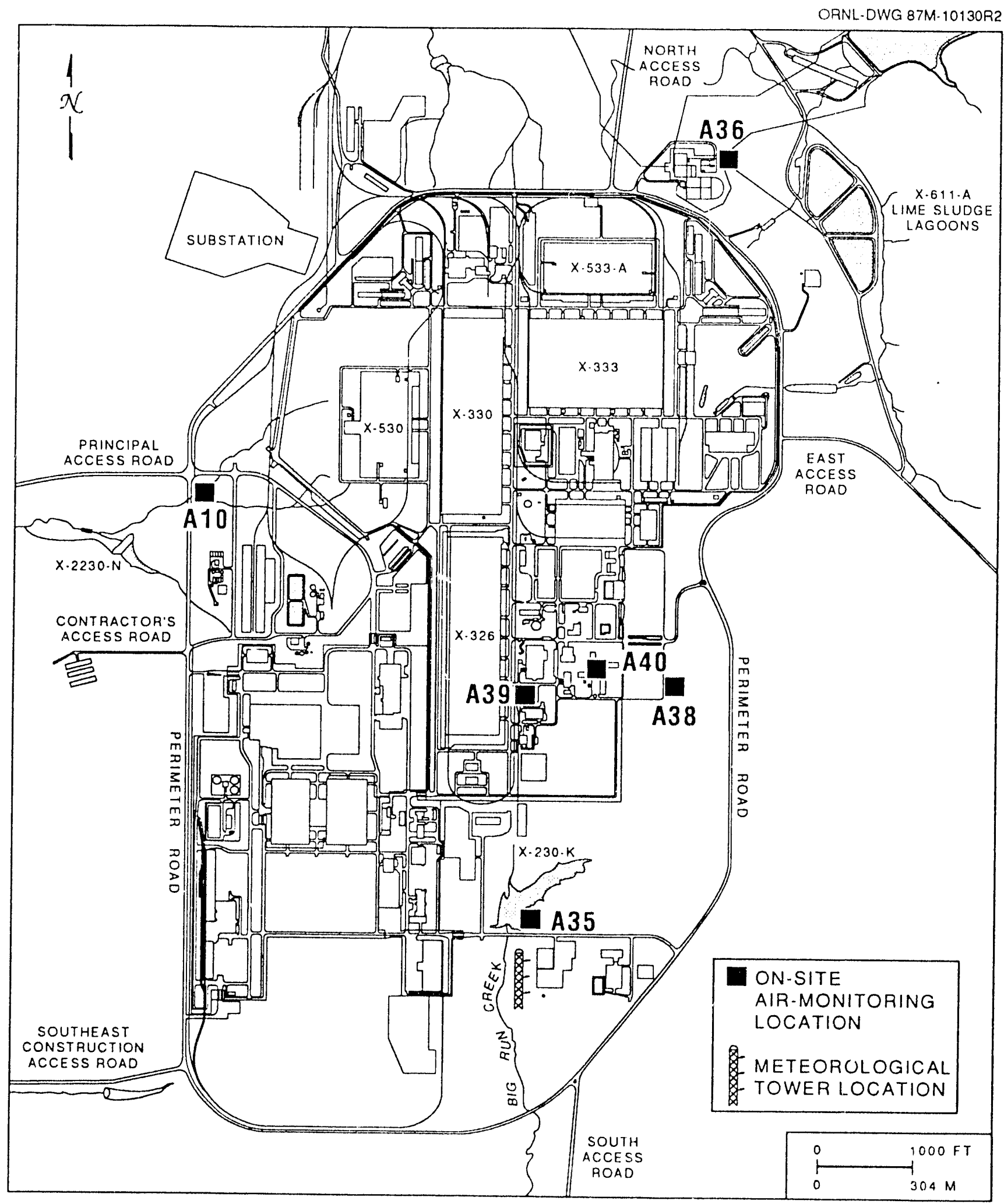

Fig. 2.1. PORTS on-site air monitoring locations and meteorological tower. 
The enrichment cascade is dividud into six "control areas," each of which has its own control room and seal exhaust station. The seal exhaust stations exhaust "dry air" (i.e., completely dehumidified air as opposed to normai, or wet, air) from the cascade seal systems. The "dry air" passes through activated alumina traps, vacuum pumps, and oil traps (i.e., mist eliminators) before being vented. The seal exhaust station in X-333 (Area 1) was equipped with a continuous sampler on an experimental basis in early 1989. Present plans are to equip the other five stations with samplers in 1991.

In addition to the continuous samplers, other systems monitor the emissions from the cascade vents. Process control is baud on real-time information provided by ionization-chamber-type instruments called "space recorders." Space recorders have limited sensitivity and cannot disinguish between uranium and teclinetium emissions, but they provide adequate qualitative information for operating purposes. The space recorders are checked (every $4 \mathrm{~h}$ on the purge cascades) by 5-L grab samples that are analyzed on a priority basis. Grab samples provide only limited information, however, and some data suggest that the technetium concentrations in the grab samples may be biased high under some conditions. The 5-L samples are also less sensitive than the weekly samples, which represent several thousand liters of sampled vent gases. The PORTS plant laboratory is currently developing a modification of the continuous sampler that would use a pair of gamma detectors to measure uranium accumulation in the traps in real time. Current major problems are background drift and a need to know the assay of the uranium emissions in advance.

\subsubsection{Criteria pollutant emissions}

PORTS operates numerous small sources of criteria (or "conventiona") air pollutants. The three most significant are the enal-fired boilers at the $X-60)$ steam plant, which supply the plant with 125 -psi steam for process and huilding heat. Typically, only one or two boilers operate at a time depending on outside temperatures. The boilers are permitter hy OEPA with opacity, particulate, and sulfur dioxide $\left(\mathrm{SO}_{2}\right)$ limits. These permits also specify the required emission monitoring for these parameters, which is reported to OEPA on a quarterly basis.

Opacity and particulate emissions are controlled by electrostatic precipitators on each of the boilers. Opacity is measured continuously and recorded on 24-h circular charts and monthly strip charts. Opacity is a measure of the darkness of a plume of smoke and is measured by shining a heam of light through the smoke and measuring the percentage of light that passes through. Environmental regulations specify a limit of $20 \%$ opacity, which is equivalent to a light haze. Opacity is also used as a daily indicator of particulate emissions; this requires time-consuming and difficult stack sampling to measure directly. Such stack sampling (and 100\% compliance with particulate limitations) is required to renew the OEPA operating permits every 3 years.

Sulfur dioxide emissions are calculated from coal analyses rather than direct measurement. All coal deliveries to the plant are sampled and analyzed for calorific value (Btu/lb), ash content, and sulfur content. The quarterly reports to OEPA summarize the amount of coal purchased, the average results of the coal analyses, and the calculated rate of $\mathrm{SO}_{2}$ emission along with the opacity data.

In addition to $\mathrm{SO}_{2}$ emissions from the $\mathrm{X}-600$ steam plant, PORTS also purchases liquid $\mathrm{SO}_{2}$ in 1-ton cylinders for treatment of the plant cooling water blowdown at the X-616 liquid effluent treatment facility. The $\mathrm{SO}_{2}$ is injected into the inenming blowdown water and is consumed by a reaction that reduces hexavalent chromium (a corrosion inhibitor in the cooling water) to the less toxic trivalent form. No odor of $\mathrm{SO}_{2}$ is normally present around the X-616 facility; this indicates that essentially all of the $\mathrm{SO}_{2}$ is consumed. Realistically, some small amount of $\mathrm{SO}_{2}$ is probably emitted from this process, but the absence of an odor indicates that this emission is insignificant compared to emissions from the steam plant.

In addition to vie pollutants discussed above, all fossil-fuel burning equipment emits nitrogen oxides $\left(\mathrm{NO}_{\mathbf{x}}\right.$ ) and carbon monoxide $(\mathrm{CO})$. The primary source of NO, and CO at PORTS is, of course, the steam plant itself. In addition, there are minor contributions of these pollutants from oil-fired heaters, stationary diesel motors and mobile sources (cars and trucks). 


\subsubsection{Othe: airborne emissions}

Other air pollutants emitted from PORTS include chlorine, hydrogen fluoride, methanol, chromium, assorted solvents, and coolants. The amounts of these chemicals emitted are estimated for annual reports to U.S. EPA as required under Section 313 of the Superfund Amendments and Reauthorization Act (St:A 313) and are incorporated in this report.

PORTS purchases liquid chlorine $\left(\mathrm{Cl}_{2}\right)$ for water treatment. Chlorine is used to disinfect incoming well water, outgoing treated sewage, and in-plant recirculating cooling water ( $R C W$ ). Very little, if any, chlorine is lost to the air from the incoming water or the sewage, but the RCW is effectively air-stripped of chlorine in the cooling towers.

Fluorine is used to condition and dry process equipment, and also to recover deposits of uranium compounds resulting from wet-air leakage into the cascade. Instead of shipping and storing large amounts of tluorine gas, PORTS purchases less dangerous $\mathrm{HF}$ in $850-\mathrm{lb}$ cylinders and converts it to fluorine as needed on-site. The fluorine reconverts to $\mathrm{HF}$ within the cascade. Hydrogen fluoride emissions from the cascade are directly monitored with the same contin: nis vent samplers used to monitor radionuclide emissions.

Methanol is used as a feed material for the Biodenitrification Facility in X-705. The Biodentrification Facility is an NPDES-permitted wastewater treatment unit that uses bacteria to decompose waterborne nitrates into nitrogen gas before discharge to the X-6619 Sewage Treatment Plant. Methanol is added to the incoming wastewater as a food for the bacteria, and some evaporates into the air.

Chromium, in the form of sodium dichromate, is added to PORTS' RCW as a corrosion inhibitor. When the RCW passes through the cooling towers, some water is picked up ("entrained") by the air flow, and it carries its associated chromium ( $\sim 9 \mathrm{ppm})$ out the top of the towers. This emission is being eliminated by the systematic replacement of sodium dichromate by a phosphate-based corrosion inhibitor.

PORTS uses both hydrocarbon and non-hydrocarbon solvents for cleaning purposes, with 1,1,1-trichloroethane (TCA) and Freon 113 being the primary solvents. TCA is used to "degrease" equipment prior to maintenance or repair. Freon 113 is used for final cleaning of parts (e.g., piping. gaskets, etc.) that may come in contact with $\mathrm{UF}_{6}$ process gas. Both solvents are assumed to evaporate completely, and TCA is recycled until it evaporates. Smaller amounts of other hydrocarbon solvents, such as acetone, are also used and are assumed to evaporate completely. The non-hydrocarbon solvents used at PORTS (primarily nitric and citric acids in water) are not volatile enough to contribute significantly to air emissions.

The gaseous diffusion process generates a large amount of heat that must be removed by the plant cooling system. Because water is a nuclear moderator and is chemically reactive with $U_{6}$, it would be unsafe to cool the process directly with the RCW, so PORTS uses a two-stage system with Freon 114 as the intermediate coolant. Inevitably, given the size of the cooling system, a considerable amount of the Freon leaks into the cascade, into the RCW, or directly into the air. A "thermal degrader" destroys th: Freon that enters the cascade, but Freon emissions from the RCW system and building ventilation are difficult to control. Currently, estimates of total Freon emissions are based on monthly inventories and include no allowance for Freon destroyed in the cascade. Comparatively small amounts of other coolants such as Freon 12, Freon 22, and ethylene glycol are lost from plant air conditioners.

Another air pollutant present at PORTS is asbestos from the renovation or demolition of plant facilities. Asbestos emissions are not included under SARA 313, and no quantified emission level is available. Asbestos emissions are controlled to the level of "no visible emissions" by a system of work practices supervised by the Industrial Hygiene Department. The amount of asbestos removed and disposed of is reported is OEPA on a quarterly basis, but currently no practical way exists to estimate reliably the amount of asbestos actually emitted to the atmosphere from renovation or demolition activitics.

\subsubsection{Emission Data Summary}

\subsubsection{1990 radionuclide emissions}

Routine radionuclide emissions from PORTS (Table 2.2) had no significant impact on public health or the r-vironment, and there were no unplanned releases of radionuclides to the environment in 1990. Uranium emissions decreased by over 50\% from 1989 levels. The 1989 emissions were somewhat elevated 
Table 2.2. 1990 PORTS radionuclide air emissions

\begin{tabular}{cll}
\hline Radionuclide & $\mathrm{kg} /$ year & $\mathrm{Ci} /$ year \\
\hline${ }^{234} \mathrm{U}$ & 0.00632 & 0.0389 \\
${ }^{235} \mathrm{U}$ & 0.525 & 0.00112 \\
${ }^{236} \mathrm{U}$ & & 0.0000061 \\
${ }^{238} \mathrm{U}$ & 0.000095 & \\
${ }^{99} \mathrm{Tc}$ & 4.69 & 0.00156 \\
Uranium & 0.00289 & 0.0495 \\
daughters & $6.94 \mathrm{E}-11$ & 0.00424 \\
\hline
\end{tabular}

from, and the 1990 uranium emissions were about even with, historical routine emission levels. These historical levels were based on operation at half to three-quarters of PORTS' capacity, while 1989 and 1990 operations were close to maximum capacity. Technetium emissions during 1990 decreased by almost 50\% from 1989, a record low, to the lowest level recorded since technetium was identified in PORTS air emissions in 1977. Approximately $70 \%$ of the uranium activity and $30 \%$ of the uraniurn mass were released from the top- and side-purge cascades in the X-326 process building. Approximately $75 \%$ of the technetium emissions also were released from the top- and side-purge cascades.

Typically, technetium emissions are marked by very low normal emissions; one or two comparatively large spikes or "bubbles" from the top- and side-purge cascades provide the majority of the annual emissions. In. 1990, although monthly emissions did vary somewhat, there were no outstanding technetium bubbles, and a significant fraction of the reported emissions were "detection limit" samples. (That is, a sample where the reported emission represents the laboratory's detection limit rather than a measurable amount of technetium in the sample.) Consequently, actual technetium emissions may be even lower than the reported emissions.

\subsubsection{1990 steam plant emissions}

The X-600 steam plant achieved annual permit compliance rates of $99.94 \%$ with its opacity limits. During 1990, the three boilers operated a total of $17,309 \mathrm{~h}$ and $30 \mathrm{~min}$ exclusive of startup and shutdown periods exempted from opacity limits, and were in compliance with opacity limits for all but $666 \mathrm{~min}$ of that time.

The opacity violations in 1990 were caused by two mechanical failures involving the stokers, a stoker that became plugged during heavy rainfall, an induction fan failure, an electrostatic precipitator that shorted out electrically, and an instrument malfunction. Two additional exceedances occurred when one of the two operating boilers was shut down for repairs, and the entire steam load was shifted to the second boiler, doubling its load. In both cases, the third boiler was unavailable because it was undergoing an annual overhaul. The control equipment can handle normal changes in demand, but a $100 \%$ increase is beyond its capabilities. Such an increase usually results in an exceedance on the second boiler.

In February, a 12-min opacity exceedance occurred when a stoker on Boiler 1 jammed and tripped a circuit breaker. In May, Boiler 1 was shut down for repairs, and its load was shifted to Boiler 2. This load change resulted in four exceedances totaling $102 \mathrm{~min}$. In August, Boiler 1 experienced a 12-min exceedance when the steam load was increased too fast while the boiler was being prepared for a compliance test. A week later, the boiler exceeded the limit for 180 min during compliance testing when an eccentric arm on one of the stokers worked loose. Also in August, Boiler 2 experienced a six-min exceedance when one of the stokers became plugged, apparently because the coal became wet during very heavy rainfall. In October, the induction fan on Boiler 2 failed. When the steam load was shifted to Boiler 1, it exceeded the opacity limit for a total of 30 min during the next $90 \mathrm{~min}$. On the evening of November 1, the electrostatic precipitator on Boiler 2 shorted out. The boiler was immediately shut down; the unit exceeded the opacity limit for the next $198 \mathrm{~min}$. The instrument malfunction occurred when Boiler 2 was started up for compliance testing. The opacity monitor had been aligned and calibrated when the unit was cold. Following startup, thermal expansion of the metal flue threw the light source out of alignment, resulting in a false excess opacity reading. This incident is included because OEPA was not notified.

Under Ohio law, opacity exceedances caused by malfunctions and reported at the time to OEPA are not legally "violations." PORTS reports all opacity exceedances caused by malfunctions to OEPA, but normally counts them in the compliance rate listed above if the opacity limit was exceeded. 
During compliance testing in 1987, the electrostatic precipitator on Boiler 1 overloaded, and the state imposed a heat input limit in the permit to prevent exceeding the particulate emission limit. The precipitator was subsequently repaired, but the limit remained. Twice during 1990, the heat input limit was exceeded. Both times, one of the two operating boilers had been shut down because of a mechanical failure and its share of the steam load shifted to Boiler 1, doubling its demand. In the process, the heat input limit was exceeded. The first exceedance lasted $8 \mathrm{~min}$. The second lasted $30 \mathrm{~min}$ initially, with small periodic excursions above the limit for the next $6 \mathrm{~h}$. The opacity limit was never exceeded, indicating that particulate emissions never exceeded the limit.

In April 1990, PORTS was informed by OEPA that the regulatory $\mathrm{SO}_{2}$ limits for small steam plants had been lowered from $7.0 \mathrm{lb} / \mathrm{M}$ Btu to $6.16 \mathrm{lb} / \mathrm{M}$ Btu, and the X- 600 boiler permits had been modified correspondingly, effective November 1989. During this interval, PORTS had already exceeded the new $\mathrm{SO}_{2}$ limit four times, in November and December 1989 (as reported in the 1989 annual Environmental Report), in January 1990 (7.10 lb/M Btu) and in March 1990 (6.39 lb/M Btu). PORTS upgraded its coal purchasing and test procedures to prevent any recurrences of this problem. Nonetheless, the two monthly violations in each year resulted in a compliance rate of only $83 \%$ for both years.

A compliance rate for particulate (fly ash) limits does not have any real meaning because particulate emissions are measured only once every 3 years during renewal of operating permits from OEPA. Particulate emissions from Boilers 3, 2, and 1 were tested in December 1989, February 1990, and March 1990, respectively. All three boilers tested well within their permit limits, but because of technical inconsistencies in the test report, OEPA demanded a retest for Boiler 1. Boiler 1 was retested in August 1990 and again tested well within limits.

Renewed permits were issued by OEPA for Boilers 2 and 3 on December 14, 1990, and for Boiler 1 on December 21, 1990.

\subsubsection{Long-term trends}

Figures 2.2 through 2.4 show the PORTS emission levels over the last 5 years for uranium and iechnetium. Figures 2.2 and 2.3 show uranium emissions in curies (a measure of radioactivity) and kilograms (a measure of mass), respectively. Both figures are included because uranium is a mixture of three different isotopes ${ }^{236} \mathrm{U}$ is a trace contaminant) with widely varying specific activities (i.e., curies per kilogram). Because of this, $1 \mathrm{Ci}$ of uranium can weigh from $9 \mathrm{~kg}$ to almost $3000 \mathrm{~kg}$, depending on what propurtions of the three isotopes are present.

Figure 2.4 shows technetium emissions in curies. Because only one isotope of technetium is present at PORTS, a figure showing mass emissions would only duplicate Fig. 2.4. Mass emissions of technetium from PORTS in 1990 were just under $3 \mathrm{~g} /$ year.

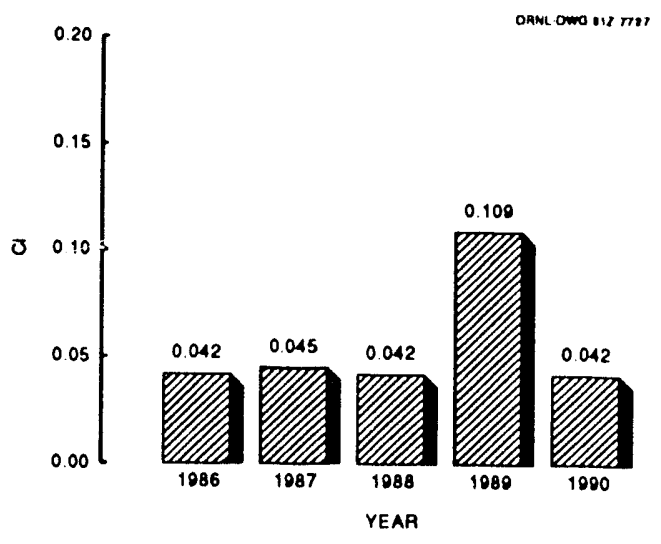

Fig. 2.2. Total curies of uranlum discharged to the air, 1986-1990.

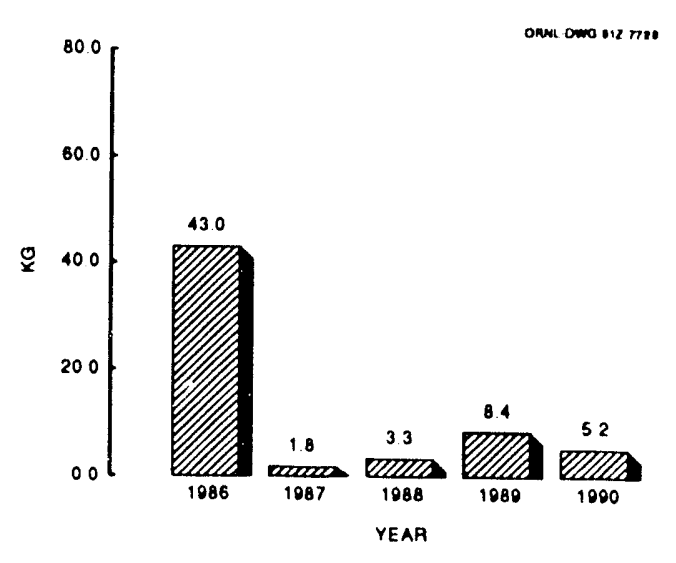

Fig. 2.3. Total kilograms of uranium discharged to the air, 1986-1990. 
Uranium daughter emissions have ranged from $0.028 \mathrm{Ci}$ /year to $0.002 \mathrm{Ci} /$ year since 1986 and have never made a significant impact on either the environment or public health. Emissions during 1990 were $0.0042 \mathrm{Ci} /$ year.

\subsection{AMBIENT AIR MONITORING}

This section describes the ambient-airmonitoring network maintained by PORTS and presents a summary of the ambient air data at each of the air-monitoring stations. Detailed ambient-airmonitoring data are presented in Tables $2.5,2.6$, and 2.7 of Part 2.

\subsubsection{Description of Ambient-Air-Monitoring System}

Since 1964 PORTS has maintained a network of on-site and off-site permanent stations to collect ambient air samples continuously. Figures 2.1 and 2.5 show the locations of the stations in the present network. Each station consists of a Teflon particulate filter, a chemically treated filter for gaseous fluorides, a flow controller and gas meter, and a vacuum pump.

The particulate filters are collected monthly and counted for gross alpha and beta-gamma loading. If the gross counts exceed plant-established limits (100 dpm alpha or $200 \mathrm{dpm}$ beta-gamma), the filters are analyzed for specific radionuclides. To date, air

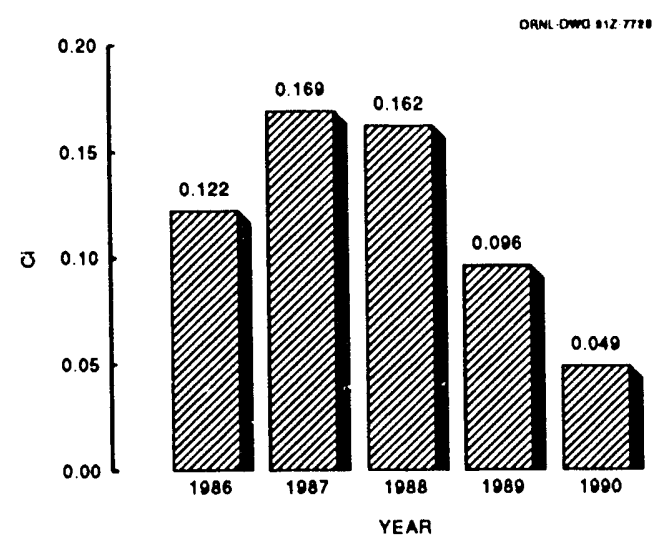

Fig. 2.4. Total curies of technetium discharged to the air, 1986-1990.

samples have never exceeded these limits. All filters that show any positive counts are saved for an annual composite analysis for specific radionuclides to verify that no unexpected radionuclides are being discharged to the air. The treated filters are collected weekly and analyzed for total fluorides. To prevent cross contamination and to simplify handling, the Teflon and treated filters are mounted in separate Teflon filter holders.

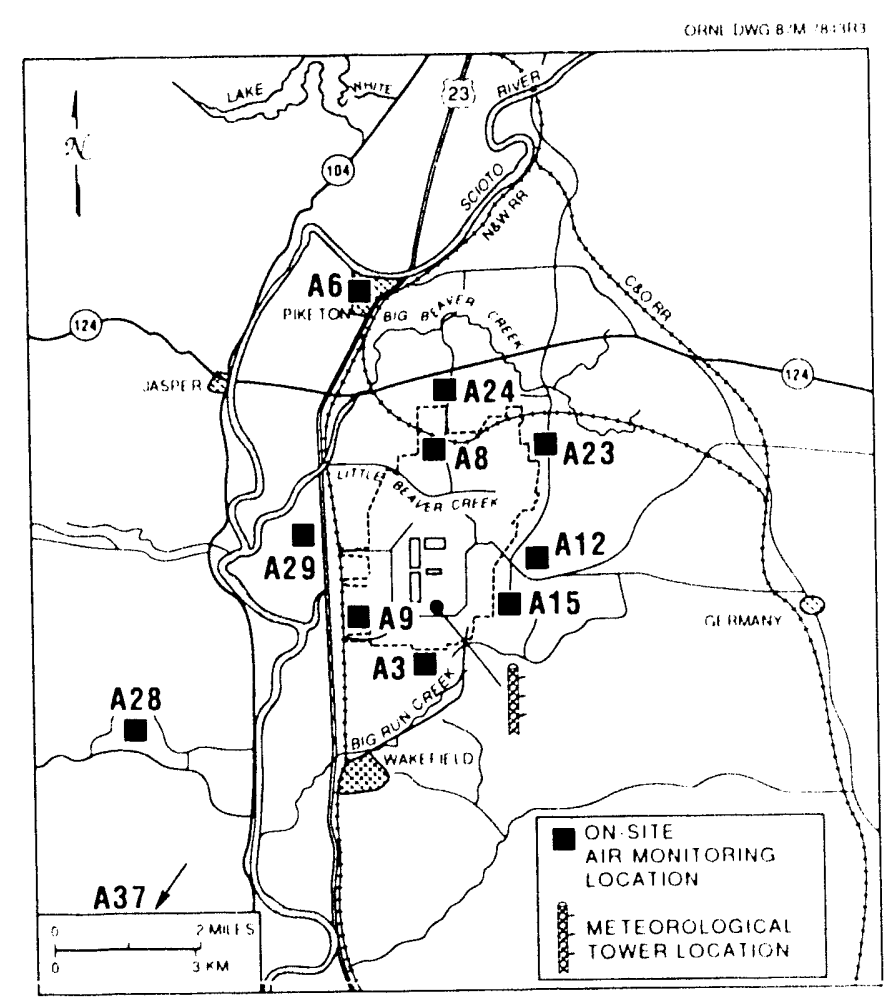

Fig. 2.5. Off-site air monitoring locations at PORTS. 


\subsubsection{Ambient Air Data Summary}

Tables 2.3 and 2.4 present summaries of the airborne gross alpha and beta-gamma radiation concentrations on and around PORTS in 1990. The tables give the number of samples; the minimum, maximum, and average concentrations; and the standard deviation of the concentrations at each air station. Note that the standard deviations are on the same order of magnitude as the average concentrations. This reflects large variations in concentrations at each station and indicates that small differences in the average concentrations are probably not significant. That is, the different stations are not recording significantly different concentrations.

Several of the minimum concentrations listed in Table 2.3 and one in Table 2.4 are negative numbers. This is a consequence of the extremely low airborne radionuclide concentrations surrounding PORTS. All measuring instruments have some limit of precision (or error) within which the instrument readings waver higher or lower randomly (better instruments having tighter limits). Usually, these limits are insignificant compared with the parameter being measured and are ignored. The airborne alpha concentrations surrounding PORTS (and most other places) are so close to zero, however, that this imprecision is not insignificant and results in occasional negative "concentration." In such cases, the average of several measurements is more realistic than the individual measurement, because the random errors tend to cancel each other.

Historically, Station A12, located on the east side of the plant, shows the highest ambient concentration of both alpha and beta-gamma activity, although by only a slight amount. In 1990, this slight increase was not visible among the random variation between

Table 2.3. 1990 gross alpha concentrations in amblent air

\begin{tabular}{|c|c|c|c|c|c|}
\hline \multirow[t]{2}{*}{ Location } & \multirow{2}{*}{$\begin{array}{l}\text { Number of } \\
\text { samples }\end{array}$} & \multicolumn{3}{|c|}{$\begin{array}{l}\text { Concentration } \\
\left(p \mathrm{pi} / \mathrm{m}^{3}\right)\end{array}$} & \multirow{2}{*}{$\begin{array}{l}\text { Standard } \\
\text { deviation }\end{array}$} \\
\hline & & $\operatorname{Max}$ & $\mathrm{Min}$ & Av & \\
\hline \multicolumn{6}{|c|}{ On-site } \\
\hline $\begin{array}{l}\text { A10 } \\
\text { A35 } \\
\text { A36 } \\
\text { A38 } \\
\text { A39 } \\
\text { A40 }\end{array}$ & $\begin{array}{l}12 \\
12 \\
12 \\
12 \\
12 \\
12\end{array}$ & $\begin{array}{l}0.011 \\
0.009 \\
0.009 \\
0.009 \\
0.020 \\
0.010\end{array}$ & $\begin{array}{l}0.000 \\
0.001 \\
0.001 \\
0.001 \\
0.002 \\
0.003\end{array}$ & $\begin{array}{l}0.004 \\
0.005 \\
0.004 \\
0.005 \\
0.009 \\
0.007\end{array}$ & $\begin{array}{l}0.003 \\
0.002 \\
0.002 \\
0.002 \\
0.005 \\
0.002\end{array}$ \\
\hline \multicolumn{6}{|c|}{ Property line } \\
\hline A3 & 10 & 0.012 & -0.003 & 0.005 & 0.005 \\
\hline A8 & 12 & 0.005 & -0.001 & 0.003 & 0.002 \\
\hline A9 & 12 & 0.010 & 0.000 & 0.004 & 0.003 \\
\hline $\mathrm{A} 12$ & 12 & 0.008 & 0.000 & 0.003 & 0.003 \\
\hline A 15 & 12 & 0.011 & 0.000 & 0.005 & 0.003 \\
\hline A23 & 12 & 0.006 & -0.001 & 0.003 & 0.002 \\
\hline A24 & 12 & 0.010 & -0.001 & 0.003 & 0.003 \\
\hline A29 & 12 & 0.007 & 0.001 & 0.003 & 0.002 \\
\hline \multicolumn{6}{|c|}{ Off-site } \\
\hline A6 & 12 & 0.015 & -0.001 & 0.006 & 0.005 \\
\hline A28 & 12 & 0.008 & 0.000 & 0.004 & 0.003 \\
\hline A 37 & 12 & 0.006 & -0.000 & 0.002 & 0.002 \\
\hline
\end{tabular}


Table 2.4. 1990 gross beta-gamma concentrations in amblent air

\begin{tabular}{|c|c|c|c|c|c|}
\hline \multirow{2}{*}{ Location } & \multirow{2}{*}{$\begin{array}{l}\text { Number of } \\
\text { samples }\end{array}$} & \multicolumn{3}{|c|}{$\begin{array}{l}\text { Concentration } \\
\left(\mathrm{pCi} / \mathrm{m}^{3}\right)\end{array}$} & \multirow{2}{*}{$\begin{array}{l}\text { Standard } \\
\text { deviation }\end{array}$} \\
\hline & & $\operatorname{Max}$ & Min & Av & \\
\hline \multicolumn{6}{|c|}{ On-site } \\
\hline $\begin{array}{l}\text { A10 } \\
\text { A35 } \\
\text { A36 } \\
\text { A38 } \\
\text { A39 } \\
\text { A40 }\end{array}$ & $\begin{array}{l}12 \\
12 \\
12 \\
12 \\
12 \\
12\end{array}$ & $\begin{array}{l}0.055 \\
0.043 \\
0.271 \\
0.228 \\
0.288 \\
0.053\end{array}$ & $\begin{array}{l}0.016 \\
0.014 \\
0.013 \\
0.009 \\
0.020 \\
0.027\end{array}$ & $\begin{array}{l}0.032 \\
0.030 \\
0.047 \\
0.041 \\
0.056 \\
0.038\end{array}$ & $\begin{array}{l}0.009 \\
0.010 \\
0.068 \\
0.057 \\
0.071 \\
0.008\end{array}$ \\
\hline \multicolumn{6}{|c|}{ Property line } \\
\hline $\begin{array}{l}\text { A3 } \\
\text { A8 } \\
\text { A9 } \\
\text { A12 } \\
\text { A15 } \\
\text { A23 } \\
\text { A24 } \\
\text { A29 }\end{array}$ & $\begin{array}{l}10 \\
12 \\
12 \\
12 \\
12 \\
12 \\
12 \\
12\end{array}$ & $\begin{array}{l}0.045 \\
0.045 \\
0.042 \\
0.045 \\
0.061 \\
0.051 \\
0.050 \\
0.045\end{array}$ & $\begin{array}{r}0.000 \\
-0.001 \\
0.017 \\
0.001 \\
0.014 \\
0.003 \\
0.007 \\
0.010\end{array}$ & $\begin{array}{l}0.031 \\
0.026 \\
0.029 \\
0.028 \\
0.034 \\
0.026 \\
0.030 \\
0.027\end{array}$ & $\begin{array}{l}0.013 \\
0.012 \\
0.009 \\
0.014 \\
0.013 \\
0.011 \\
0.013 \\
0.011\end{array}$ \\
\hline \multicolumn{6}{|c|}{ Off-site } \\
\hline $\begin{array}{l}\text { A6 } \\
\text { A28 } \\
\text { A37 }\end{array}$ & $\begin{array}{l}12 \\
12 \\
12\end{array}$ & $\begin{array}{l}0.078 \\
0.061 \\
0.063\end{array}$ & $\begin{array}{l}0.025 \\
0.028 \\
0.012\end{array}$ & $\begin{array}{l}0.044 \\
0.046 \\
0.028\end{array}$ & $\begin{array}{l}0.017 \\
0.009 \\
0.014\end{array}$ \\
\hline
\end{tabular}

samples, however. The average off-site measured alpha concentrations ranged from 0.002 to $0.006 \mathrm{pCi} / \mathrm{m}^{3}$. The highest concentration was found at Station A6 in Piketon, $7.5 \mathrm{~km}$ northwest of the plant, followed by Stations A3 and A15, which are located on the southeast reservation boundary and are normally upwind of the plant. The lowest average measured alpha concentration was recorded at Station A37, which is the background location $\sim 21 \mathrm{~km}$ southwest (upwind) of the plant.

The average off-site measured beta-gamma concentrations ranged from 0.028 to $0.046 \mathrm{pCi} / \mathrm{m}^{3}$, with the two highest concentrations found at Station A28 $(6.9 \mathrm{~km}$ southwest of the plant and between Station A37 and the plant) and Station A6. The lowest average measured beta-gamma concentrations were recorded at Stations A8 and A23, which are located on the northwest and the northeast corners of the reservation boundary and normally are downwind of the plant.

The data in Tables 2.3 and 2.4 are "gross" concentrations; these include natural radionuclides as well as emissions from PORTS and operations at other facilities including coal-fired power plants. PORTS calculates "net" concentrations due only to its own emissions by subtracting the average background concentration (i.e., the radionuclides that were present before the plant emissions were added) from the highest average concentration measured around the DOE property line. The background concentration is measured at station A37, which is located $\sim 21 \mathrm{~km}$ (13 miles) from the plant near the community of Otway.

In 1990 the highest net average alpha concentration was $0.002 \mathrm{pCi} / \mathrm{m}^{3}$ above background; the highest net average beta-gamma concentration was $0.005 \mathrm{pCi} / \mathrm{m}^{3}$. (Some roundoff error is apparent 
between these figures and Tables 2.3 and 2.4.) This net alpha concentration is the highest such concentration within the last 5 years. A review of past years' annual reports will show that gross concentrations around PORTS were about the same as last year's. The difference is in the average gross alpha concentration at Station A37 (the official background). Typically, Station A37 records concentrations equal to or slightly above those at Station A28 (see Fig. 2.5) and only slightly below the property-line stations, but in 1990 Station A37 recorded annual average concentrations approximately half of those recorded at A28. The significance of this is not clear. The average gross alpha concentrations appear to be unusually low at A37 and normal at A28, but the average gross beta-gamma concentrations appear to be normal at A37 and unusually high at A28. Consequently the 1990 net airborne alpha concentration may be exaggerated (Fig. 2.6).

A consequence of the low ambient concentrations is that it is difficult to actually analyze for specific radionuclides (e.g., uranium, technetium, etc.). PORTS therefore assumes that all the net alpha concentration is from uranium emissions from PORTS and that all the net beta-gamma concentration is from technetium and uranium daughters in the same proportion as the measured emissions.

\subsubsection{1990 ambient gross fluorides}

Table 2.5 presents a summary of the weekly ambient-fluoride-sampling program in the same format as the previous tables. In this table the state Ambient Air Quality Standards (AAQS) from Kentucky and Tennessee are included for comparison only. Although these standards are not legally bindin : on an Ohio facility, neither the state of Ohio nor the federal EPA has issued standards for ambient gaseous fluorides. Fu-thermore, there is wide disagreement between states that have issued ambient fluoride standards: Kentucky has set a primary (i.e., public health) standard of $400 \mu \mathrm{g} / \mathrm{m}^{3}$ and a secondary (i.e., public welfare) standard of $0.8 \mu \mathrm{g} / \mathrm{m}^{3}$; Tennessee has set both primary and secondary standards at $1.6 \mu \mathrm{g} / \mathrm{m}^{3}$; and Montana and Idaho do not use airborne concentrations at all (standards are based on fluoride concentrations in local vegetation instead). PORTS also measures vegetation fluoride levels (Sect. 6); this may give a more accurate idea of the environmental impact of plant fluoride emissions.

Table 2.5 presents a summary of all of the gaseous fluoride samples collected during 1990. All of the property-line and off-site stations had annual average concentrations well below the Kentucky and Tennessee standards. In 1990, only one of the off-site or property-line stations exceeded the Kentucky secondary standard (the tightest in the nation) even once, and that time only slightly. Strictly, AAQS apply only to areas "accessible to the general public" and hence cannot apply to on-site stations. Nonetheless, the average on-site fluoride concentrations are within both the Kentucky and Tennessee AAQS, although most of the on-site locations exceeded the Kentucky secondary standard at least once. Station A39, which is located literally across the street from one of the plant's larger fluoride emission sources, was the only station to exceed the Kentucky AAQS frequently or to exceed the Tennessee AAQS at all.

As with the radionuclide results ocal variability dominated the ambient fluoride monitoring. The highest recorded annual average concentration $\left(0.017 \mu \mathrm{g} / \mathrm{m}^{3}\right)$ was recorded at Station $\mathrm{A} 3$, southeast of the plant, and the second highest $\left(0.016 \mu \mathrm{g} / \mathrm{m}^{3}\right)$ at Station A37, the background station located approximately $21 \mathrm{~km}$ (13 miles) southwest of the plant.

In general, the ambient fluoride concentrations continued to decrease between 1989 and 1990 , although not as much as between 1988 and 1989 . Because PORTS has not made any operational change that would significantly reduce fluoride emissions, the most probable explanation for the trend is a decrease by a large fluoride emission source operating somewhere southwest (possibly far southwest) of PORTS. PORTS is aware of no information indicating what this source might be.

\subsubsection{Long-term trends}

Figures 2.6 through 2.8 show graphically the net ambient concentrations of a.pha and beta-gamma radioactive particles and gaseous fluorides over the last 5 years around PORTS. The only definite conclusion that can be drawn from these figures is that PORTS' contributions to the ambient concentrations of these pollutants are corsistently small. The figures show consistently small net 
Table 2.5. 1990 total gaseous fluoride concentrattons (as HF) in amblent air

\begin{tabular}{|c|c|c|c|c|c|c|}
\hline \multirow[t]{2}{*}{ Location } & \multirow{2}{*}{$\begin{array}{l}\text { Number of } \\
\text { samples }\end{array}$} & \multicolumn{3}{|c|}{$\begin{array}{l}\text { Concentrations } \\
\left(\mu \mathrm{g} / \mathrm{m}^{3}\right)\end{array}$} & \multirow{2}{*}{$\begin{array}{l}\text { Standard } \\
\text { deviation }\end{array}$} & \multirow{2}{*}{$\begin{array}{c}\mathrm{Ky} / \mathrm{Tenn} \\
\text { standards } \\
\left(\mu \mathrm{g} / \mathrm{m}^{3}\right)\end{array}$} \\
\hline & & $\operatorname{Max}$ & $\operatorname{Min}$ & $A v$ & & \\
\hline \multicolumn{7}{|c|}{ On-site } \\
\hline A10 & 47 & 0.60 & -0.04 & 0.12 & 0.10 & N/A \\
\hline A35 & 50 & 0.34 & -0.06 & 0.11 & 0.08 & \\
\hline A36 & 50 & 0.81 & -0.05 & 0.17 & 0.14 & \\
\hline A38 & 47 & 0.81 & 0.01 & 0.23 & 0.16 & \\
\hline A39 & 49 & 1.96 & -0.01 & 0.60 & 0.43 & \\
\hline A40 & 47 & 1.16 & -0.03 & 0.36 & 0.24 & \\
\hline \multicolumn{7}{|c|}{ Property line } \\
\hline A3 & 40 & 0.86 & -0.06 & 0.17 & 0.16 & $0.8 / 1.6$ \\
\hline A8 & 47 & 0.53 & -0.05 & 0.12 & 0.12 & \\
\hline A9 & 50 & 0.35 & -0.04 & 0.10 & 0.08 & \\
\hline A12 & 46 & 0.57 & -0.05 & 0.16 & 0.12 & \\
\hline A15 & 49 & 0.43 & -0.01 & 0.13 & 0.09 & \\
\hline A23 & 51 & 0.37 & -0.05 & 0.11 & 0.08 & \\
\hline A24 & 49 & 0.50 & -0.01 & 0.11 & 0.09 & \\
\hline A29 & 51 & 0.19 & -0.01 & 0.09 & 0.05 & \\
\hline \multicolumn{7}{|c|}{ Off-site } \\
\hline A6 & 49 & 0.52 & -0.10 & 0.15 & 0.12 & $0.8 / 1.6$ \\
\hline A28 & 47 & 0.67 & -0.09 & 0.14 & 0.12 & \\
\hline A37 & 48 & 0.55 & 0.05 & 0.16 & 0.10 & \\
\hline
\end{tabular}

concentrations (relative to the gross concentrations in the preceding tables) with considerable random variation within this range. This reflects the fact that the net concentrations are approaching the size of the random-sampling and analytical errors inherent in any real-world sampling system; this is aggravated by the fact that the natural concentrations of these pollutants are larger than the net concentrations and thus mask the numbers of actual interest.

\subsection{METEOROLOGICAL MONITORING}

This subsection describes the metcorological-monitoring system in place at PORTS. This system is not part of the National Weather Service network and is designed solely to provide local meteorological data for predicting and evaluating environmental impacts of plant operations. This subsection presents only a graphic summary of wind data directly of interest to the dispersion modeling of pollutants released from the plant.

\subsubsection{Description of Meteorological System}

PORTS maintains a comparatively simple meteorological-monitoring system in keeping with a comparatively simple local wind pattern. A single meteorological tower $(X-120)$ is located south of $\mathrm{XT}-801$ (Fig. 2.5) and is equipped with instrument packages at the 10- and 40-m levels. Air temperature, dew point, and wind speed and direction are measured at both levels. In addition, there is ground-level instrumentation for measuring solar radiation, barometric pressure, precipitation, and soil 


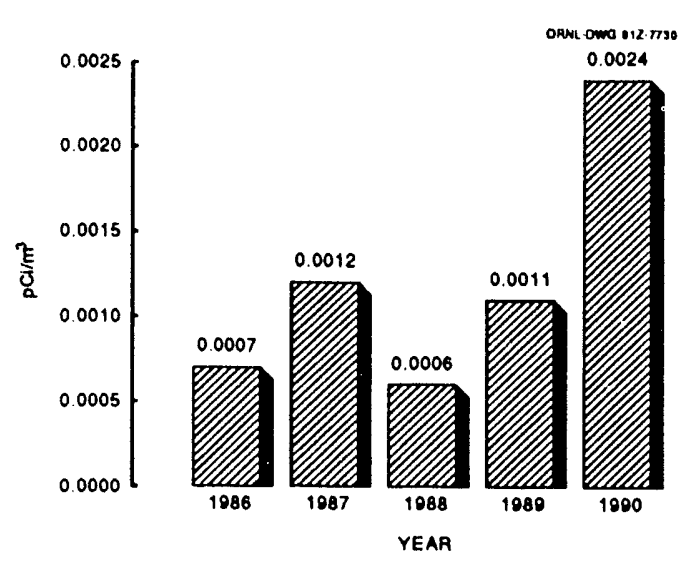

Fig. 2.6. Net airborne alpha concentrations, 1986-1990.

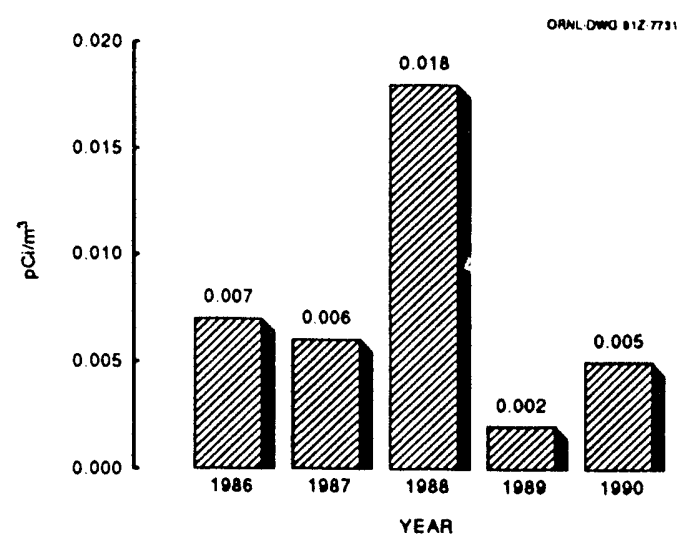

Fig. 2.7. Net airborne beta-gamma concentrations, 1986-1990.

temperaiure at 0.30 - and $0.61-\mathrm{m}$ depths. The data for 0.61 -m depths has not been available since July 11 , 1990.

On July 11, 1990, lightning struck the meteorological tower and burned out all of the instruments. A second set of instruments serves as backup to the active set. Every 6 months, the active set is replaced by the backup set and sent to the vencior for calibration. One set had just been removed

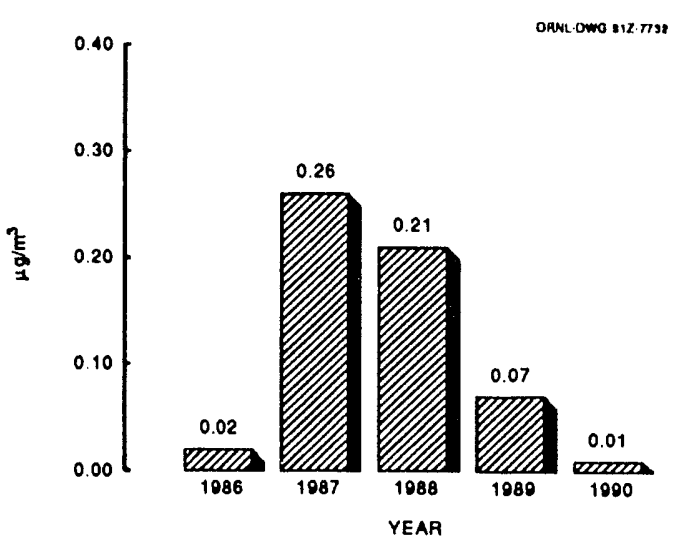

Fig. 2.8. Net gaseous fluoride concentrations, 1986-1990.

and packaged for shipment when the lightning strike occurred. These instruments were immediately retrieved and put into service on the tower.

The instruments are obsolete and replacements are not available. Other instrumentation currently available is not a direct replacement, and considerable work will be required to adapt it to the existing system. Thus, the instruments in use from July 11 , 1990 , through the end of the year were not "in calibration."

In October 1990, a portable meteorological tower was borrowed from the National Oceanographic and Atmospheric Administration (NOAA) and was placed adjacent to the permanent tower. The NOAA tower became operational on November 5, 1990. The data acquisition and reduction methods and data format from the NOAA tower are not compatible with the existing PORTS data processing system.

Consequently, data from the NOAA tower are available but cannot easily be compared directly with data from the PORTS tower. For this reason, all data presented in this report are from the PORTS tower.

A microprocessor located at the foot of the tower receives the analog data from each of the instruments and transmits two digital summaries via telephone lines to the Emergency Preparedness Department. The summaries consist of average and maximum wind speed, average and standard deviation of wind direction, averages of all temperatures, solar radiation, and precipitation over the last interval. One 
summary is sent at hourly intervals directly to a hardcopy terminal, which also serves as the control terminal of the microprocessor. The other summary is sent at 15 -min intervals to a PDT-11 microprocessor and disk drive that operates independently of the rest of the system. The PDT converts wind direction data into compass headings and stability classes and calculates humidity. The converted data are automatically retransmitted to the $X-300$ process control building and the Environmental Control Department and are averaged hourly for storage on floppy disks. The stored averages are used to generate a printed report at midnight of each day. At the end of the year, the monthly floppy disks are copied onto an annual magnetic tape that is used to generate the annual wind distribution and stability used for dispersion modeling and dose calculations.

\subsubsection{Meteorological Data Summary}

Figures 2.9 and 2.10 are standard graphic presentations of wind speed and direction data called "wind roses." The wind rose has 16 arms (representing the standard 16 wind directions), each of which is divi_ud into 6 segments (representing 6 wind speed classes). The length of each segment represents the fraction of time wind was blowing from that direction at an average speed within that class. The key at the bottom of the figure gives the maximum speed of each wind speed class except the last. This class includes all wind speeds above the first 5 classes. The primary use of a wind rose is to provide an easily understood picture of the prevailing wind patterns at a site. The relative length of the arms gives a quick indication of whish wind directions predominate and to what extent.

A joint frequency distribution is a set of tables listing the fraction of time in each of 576 wind classes ( 16 directions $\times 6$ wind speeds $\times 6$ stability classes) instead of a wind rose's 96 classes.

Atmospheric stability can be roughly described as the tendency of a wind to mix with and dilute a pollutant as opposed to merely transporting it downwind. The stability classes range from A (extremely unstable, maximum mixing) through $D$ (neutral) to $F$ (moderately stable, minimum mixing). Because of their complexity, joint frequency distributions are more useful for input to computer models than for data presentation to humans. Such computer models (known as "air dispersion models") are used to predict the downwind spread of pollutants in greater detail than an ambient-air-monitoring system can. One such model, AIRDOS-EPA, is required by EPA to make the radiation dose estimates presented in Subsect. 7.1.

\subsection{EXTERMAL GAMMA RADIATION}

External gamma radiation measurements confirm that direct radiation and radioactive effluents from PORTS are not significantly different from natural background levels. This subsection describes the external gamma-radiation-moritoring network at PORTS and presents a summary and discussion of the data collected by that network. A brief summary of the radiation doses that can be estimated from these data is also presented. A more extensive discussion of radiation dose calculations is found in Sect. 7. For a more detailed presentation of the gamma radiation data without discussion, see Subsect. 2.4, Part 2.

\subsubsection{Program Description}

PORTS uses thermoluminescent dosimeters (TLDs) to measure gamma radiation exposure. When exposed to penetrating radiation (such as gamma or cosmic radiation), thermoluminescent materials absorb and store a portion of the radiation energy. If the material is heated later, this energy will be released as light. Although thermoluminescent materials (such as clay) are fairly common, only a handful are sufficiently accurate for use in radiation measuring devices (dosimeters). Because TLDs can be reused 50 or more times, they have almost completely replaced the older film-badge system of dosimetry.

The TLDs used in the PORTS environmental program are based on two chips of a commercial thermoluminescent material $\left(\mathrm{CaF}_{2}: \mathrm{Dy}\right)$ permanently mounted in a Teflon and aluminum card. The card is mounted inside a plastic and cadmium holder for field use. These TLDs respond to gamma and neutron radiation and, to some extent, to cosmic radiation. Normally no significant levels of neutron radiation exist around PORTS, though all uranium-handling facilities have some theoretical chance of experiencing a criticality or nuclear chain reaction. Cosmic radiation, of course, is present essentially everywhere. 


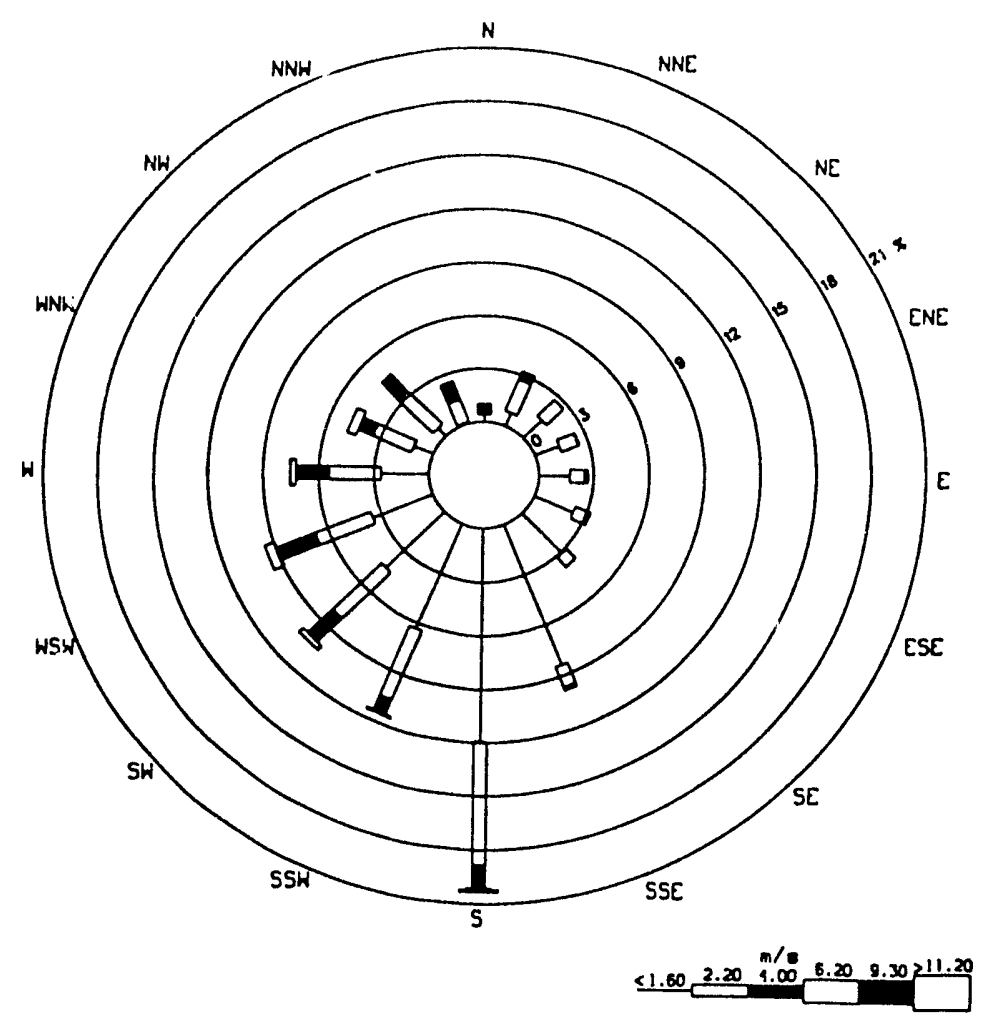

Fig. 2.9. 1990 annual wind rose at $10-\mathrm{m}$ level.

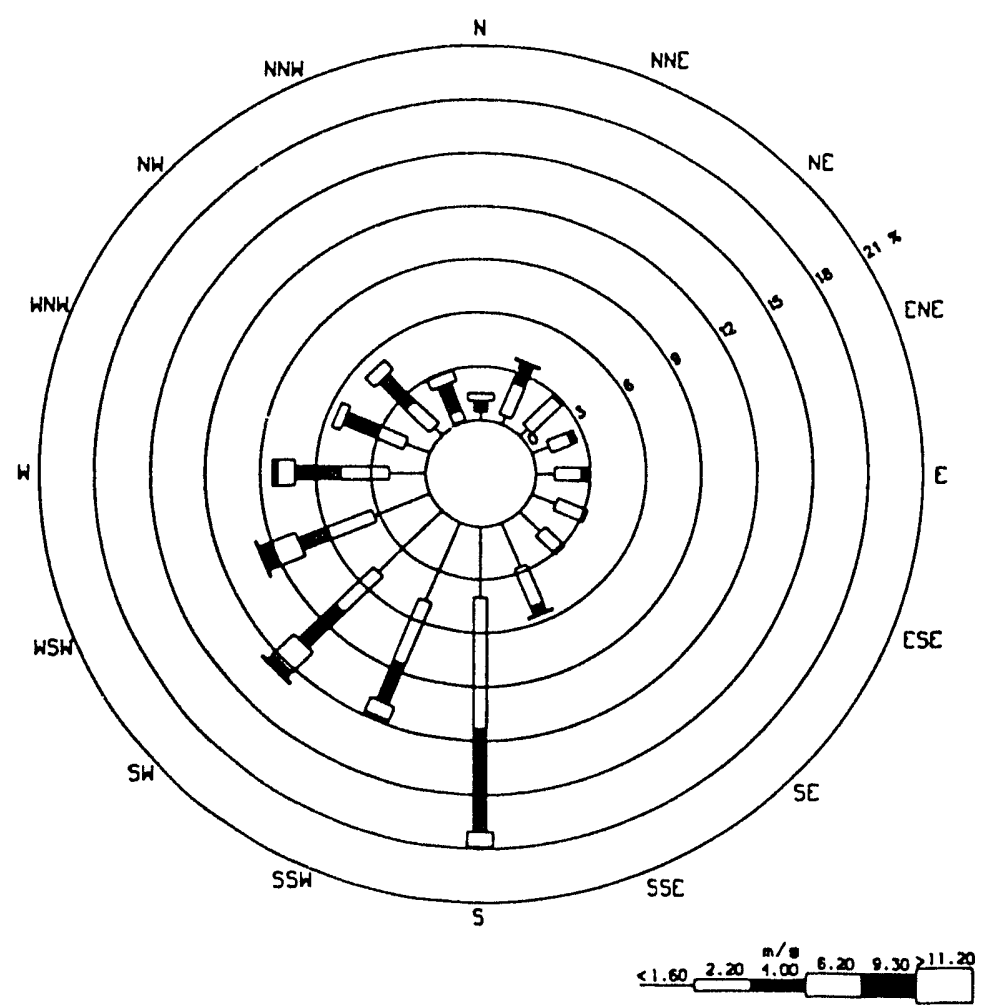

Fig. 2.10. 1990 annual wind rose at $40-\mathrm{m}$ level. 
The usual concern of the TLD network is the level of ambient or external gamma radiation around PORTS. The term "external" is used because the source of the radiation is external to the body, so only penetrating radiation is of concern. In contrast, internal sources that have been inhaled or swallowed involve nonpenetrating alpha and beta radiation. The only significant sources of gamma radiation at PORTS are the uranium isotope ${ }^{235} \mathrm{U}$ and the short-lived uranium daughters.

External gamma measurements are made in the relatively small area of the PORTS site accessible to the public, around the edge of the PORTS site, and at the ambient air sampling stations in Piketon (A6) and at Camp Creek (A28). Eight on-site field TLDs (Site Group I) are on or near Perimeter Road, which runs around the secure, or Q-cleared, area of the plant. Eight TLDs (Site Group II) are collocated with the fence-post air-monitoring stations discussed in Subsect. 2.2.1, and two off-site TLDs provide a general indication of background levels. The TLD locations are shown in Figs. 2.11 and 2.12. In addition, a group of six reference TLDs is on top of the X-100 administration building, and another group of six control TLDs is kept in a lead "pig" in the Environmental Control Department except when TLDs are being transported to and from the field. Reference and control TLDs are used in calibrating the field TLDs.

This network is considerably reduced from the off-site TLD network PORTS has maintained in previous years. Several years of data, supported by theoretical calculations, have conclusively demonstrated that the off-site TLDs will not detect any direct gamma radiation from the plant site. In view of this and of the heavy demands the labor-intensive manual TLD system used by the Environmental Control Department made on department resources, the department reduced the network to free resources to address other, more significant, environmental concerns such as $\mathrm{PCB}$ management and air-monitoring upgrades.

PORTS maintains two complete sets of TLDs (18 field, 6 reference, 6 control, and spares) that are exposed alternately on a quarterly basis. At the beginning of each calendar quarter, an unused set is annealed (i.e., zeroed by heating) and exchanged for the current set. The current set is read with a manual TLD reader. TLDs that give unusually high or low readings or that give significantly different readings between the individual chips are set aside as suspect. All TLDs are then annealed, exposed to a calibrated gamma radiation source $\left({ }^{137} \mathrm{Cs}\right)$, and reread. The nonsuspect TLDs are used to construct a calibration curve for the set, and the suspect TLDs are tested for accuracy against this curve. Suspect TLDs that fail this test are discarded along with their readings.

The external gamma radiation levels for Site Groups I and II are reported as quarterly site-group averages with one exception in Site Group I: TLD Location 874 is at the corner of a uranium storage yard, and gamma levels there are sharply higher than those on the rest of Perimeter Road. This location is reported separately to emphasize that a single hot spot exists and that the Perimeter Road in general is not an area of elevated gamma levels. This procedure is particularly important when estimating radiation dose from radiation levels. In Site Group II and off-site locations this calculation is made by multiplying the annual average gamma levels by the potential time exposed (i.e., $24 \mathrm{~h} / \mathrm{d}, 365 \mathrm{~d} /$ year) because a continuous exposure in those areas is a reasonable assumption.

Public exposure to Site Group I gamma levels is limited to through traffic on Perimeter Road and actual plant business and is much lower than the $24 \mathrm{~h} / \mathrm{d}, 365 \mathrm{~d} /$ year assumed for the other site groups. Because it is impossible to measure accurately how much lower the public exposure is and because the group average gamma level is not significantly higher than background, a conservative worst case of continuous exposure is assumed for the group average. This would not be a reasonable assumption for location 874, though. Because location 874 is away from any access roads or security fence gates, it is possible to estimate an annual exposure to members of the general public for this area. Public traffic is not allowed to stop in this area, and tests by environmental personnel have shown that a car traveling slightly under the posted speed limit passes through the hot spot in 20-30 s. PORTS therefore assumes that a person driving to and from work is the most conservative plausible case, and that this driver will always get completely through the "hot spot" within $1 \mathrm{~min}$. Total exposure can then be estimated as equal to the average gamma levels within the hot spot (e.g., half the measured peak gamma level at location 874 ) times $1 \mathrm{~min} /$ trip times 2 trips/d times 5 work 


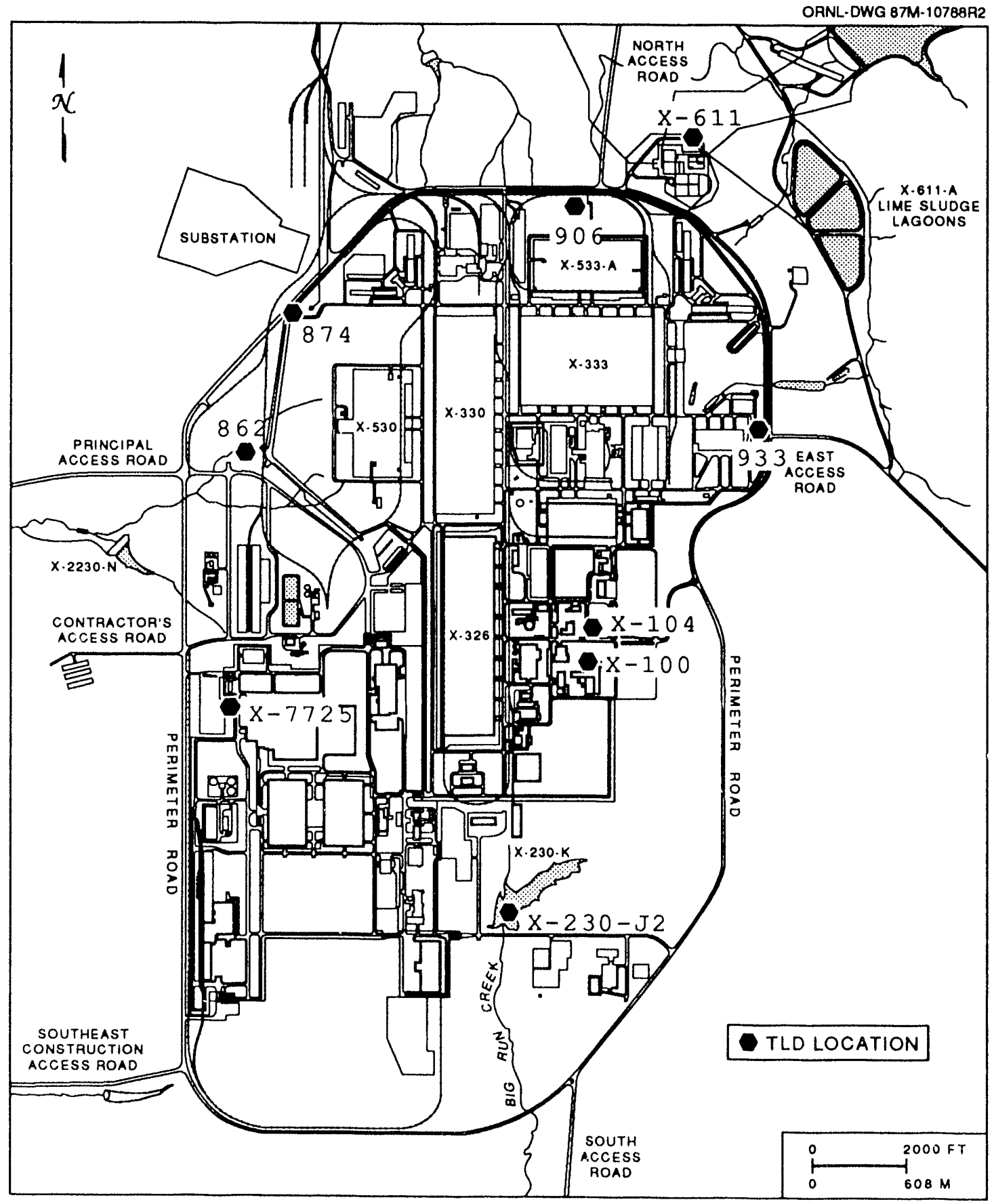

Fig. 2.11. On-site TLD locations (Site Group I). 


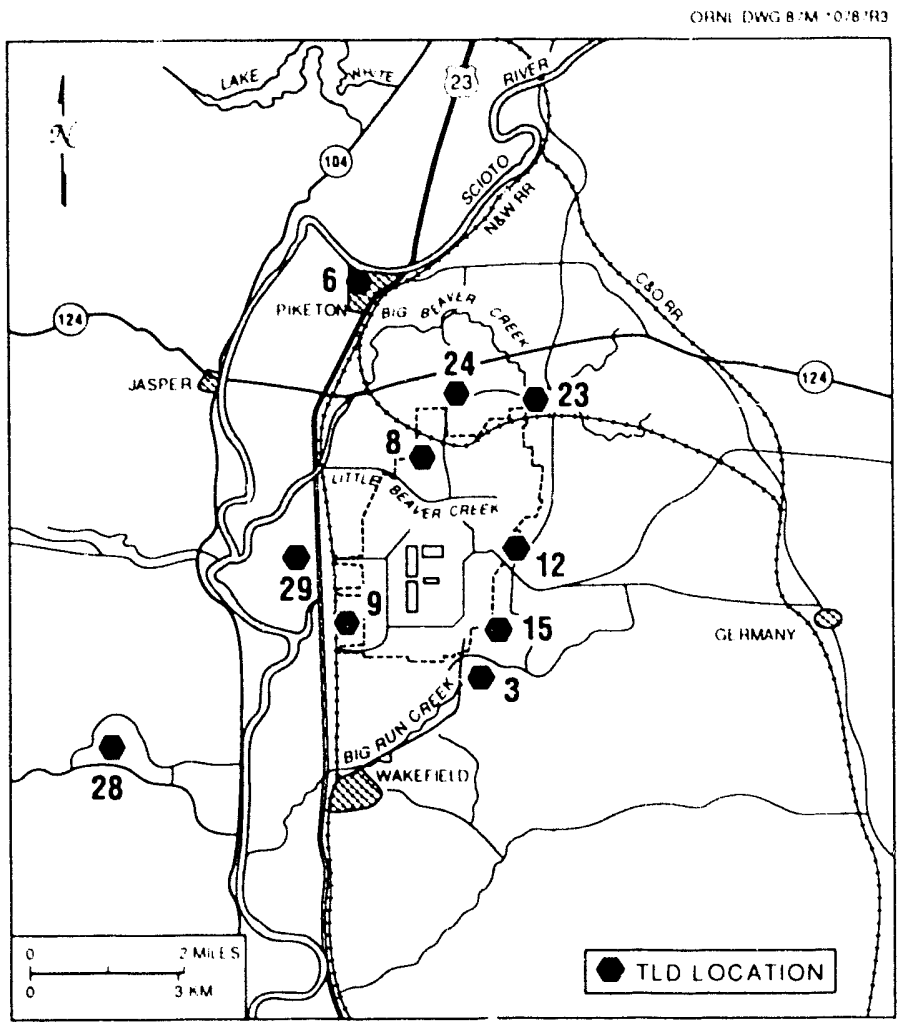

Fig. 2.12. Off-site TD locations (Site Group II).

d/week times 52 weeks/year, or 8.7 h/year times $1 / 2$ the measured radiation level at location 8,4 . Worker exposures in this and other areas of elevated gamma radiation are measured directly by a separate (and more elaborate) TLD system operated by the Health Physics Department.

\subsubsection{Thermoluminescent Dosimeter Data Summary}

Exsept for TLD location 874, external gamma levels around PORTS are not significantly different from natural background. Table 2.6 sh.uws the avcrage external gamma level (in $\mu \mathrm{r} / \mathrm{d} / \mathrm{h}$ ) plus or minus twice the standard deviation oy site group and calendar quarte.. One microrad of gamma radiation will produce $1 \mu \mathrm{rem}$ of absorbed dose equivalent in an exposed person. Quarterly average gamma levels at location 874 are shown in parentheses under the data for the rest of Site Group I. The last column shows the estimated gross annual external gamma duse within each of the site groups. For Site Group I, the annual dosage is estimated assuming continuous exposure to the group average radiation levels, and the additional dose due to the 8.7 hour/year exposure to location 874 is listed underneath.

The numbers in Table 2.6 represent gross gamma levels and doses including gamma radiation from PORTS activities and effluents, local natural sources (terrestrial gamma), and some cosmic radiation. No effort has been made to separate the natural radiation from the PORTS contribution. In theory this could be done by subtracting the external gamma level at a background location from external gamma levels at all the other locations. In practice most of the off-site TLD locations (now discontinued) around PORTS have historically recorded higher gamma levels than the supposedly more exposed TLDs on and within the site boundary.

The cause of this radiation level pattern lies in the geology of the PORTS site. As is described in Sect. 1, the PORTS plant is located within an ancient river bed that was filled with clay and silt during the glacial period. The surrounding hills and ridges, on the other hand, are largely composed of much older shale that is significantly richer in natural radioactive minerals. Most of the discontinued off-site TLDs were located among these hills and ridges, where they 
Table 2.6. 1990 amblent gamma radiation levels and doses

\begin{tabular}{|c|c|c|c|c|c|}
\hline \multirow{2}{*}{$\begin{array}{c}\text { Site } \\
\text { groups }\end{array}$} & \multicolumn{4}{|c|}{ Ambient gamma levels $(\mu \mathrm{rad} / \mathrm{h})$} & \multirow{2}{*}{$\begin{array}{c}\text { Annual dose } \\
\text { (mrem) }\end{array}$} \\
\hline & $\begin{array}{c}\text { First } \\
\text { quarter }\end{array}$ & $\begin{array}{l}\text { Second } \\
\text { quarter }\end{array}$ & $\begin{array}{l}\text { Third } \\
\text { quarter }\end{array}$ & $\begin{array}{l}\text { Fourth } \\
\text { quarter }\end{array}$ & \\
\hline $\begin{array}{l}\text { On-Site } \\
(874)\end{array}$ & $\begin{array}{c}10.9 \pm 1.2 \\
\quad(128)\end{array}$ & $\begin{array}{l}10.9 \pm 1.2 \\
\quad(132)\end{array}$ & $\begin{array}{l}11.1 \pm 1.2 \\
\quad(117)\end{array}$ & $\begin{array}{l}9.5 \pm 1.2 \\
(125)\end{array}$ & $\begin{array}{c}93 \\
(0.55)\end{array}$ \\
\hline Bisundary & $9.8 \pm 0.9$ & $10.3 \pm 1.0$ & $10.4 \pm 1.4$ & $8.6 \pm 1.4$ & 86 \\
\hline Piketon & 9.9 & 11.3 & 10.0 & 8.6 & $\partial i$ \\
\hline Camp Creek & 8.9 & 9.2 & 9.6 & 7.2 & 76 \\
\hline
\end{tabular}

were exposed to a higher level of radiation than TLDs located in the old Portsmouth, Teays, or Newark River valleys or even the on-site TLDs.

Consequently, no legitimate background level of radiation could be designated. On the other hand, plant emissions that were consistently lower than the local variation in natural backgro'snd radiation could hardly be called significant.

Of the remaining off-site TLDs, Piketon is located in the Scioto River Valley (which is within the older Newark River Valley) and has a geographic setting comparable to the Site Group II TLDs. If Piketon were not the nearest population center to the plant site, this might well be a usable background location. The Camp Creek location, on the other hand, has historically and consistently shown ambient radiation levels noticably lower than any other location ever monitored by PORTS, including locations farther away from the plant. Apparently, Camp Crcek has an unusual geography that invalidates it as a background standard for PORTS ambient radiation levels, although PORTS has not been able to discover what this difference is. Because it is a consistent indicator of how low local radiation levels can go, PORTS continues to monitor this location for a check on the other TLDs.

For comparison, Fig. 2.13 shows graphically the annual gross external radiation dose for each of the two site groups and the two off-site TLDs and average annual doses for (terrestrial) gamma radiation and for gamma plus cosmic (total) radiation for the state of Ohio. Both types of doses (gamma and total) are included because the PORTS TLD system does not completely exclude cosmic radiation. Consequently, the recorded site-group average doses, exclusive of any plant emissions, should be somewhat above the state average gamma dose and below the state average total dose. As can be seen in Fig. 2.13, the 1990 gamma radiation doses in the vicinity of PORTS are within this range. For a more general comparison, Fig. 2.14 shows average annual doses from terrestrial gamma, cosmic, and total radiation for several states and for the entire country.

\subsection{FINDINGS AND CONCLUSIONS}

Emission control programs at PORTS maintained emissions within acceptable limits. Environmental monitoring programs showed no significant impact on human health or the environment attributable to plant operations. Highlights of these programs are summarized below:

- There were no unplanned releases of radionuclides to the environment in 1990.

- Both routine uraniuin emissions and technetium emissions decreased noticeably in 1990 . The total uranium emissions (in curies) were less than half of 1989 emissions, and technetium emissions were lower than in any previous year.

- The PORTS steam plant achieved 99.94\% "physical" compliance with the opacity limits and $83 \%$ compliance with the $\mathrm{SO}_{2}$ limits in its environmental operating permits. Legal compliance with the opacity limits is even higher because Ohio regulations exempt opacity excedances that are due to malfunctions and 


\section{SURFACE WATER}

PORTS practices a progressive environmental strategy for water pollution control in compliance with requirements of the Clean Water Act (CWA). This strategy uses selection of modern pollution abatement technology followed by continual review of treatment facility performance to meet current regulations in the most cost-effective manner. Sources of new pollution are first identified and characterized by in-house laboratory studies. A project feasibility study is performed; treatment alternatives are investigated; professional architectural/engineering firms are contracted for design purposes together with continual in-house reviews; and the proposed facility is constructed, operated, and monitored to ensure compliance with all applicable laws.

PORTS' existing collection and treatment facilities are discussed in this subsection together with facility improvements, new treatment facilities, and studies to improve performance. A variety of hazardous liquid wastes (i.e., uranium-contaminated as well as noncontaminated) result from operations associated with recirculating cooling water (RCW), uranium recovery, and decontamination activities. In addition, a variety of conventional wastes exist such as domestic sewage, steam plant wastewaters, coal pile runoff, and once-throuğ wastewater sources and systems are given in Fig. 3.1.

\subsection{SURFACE WATER MONITORING}

The quality of surface waters on the DOE Reservation. is affected by wastewater discharges and by ground'water transport of contaminants from land disposal of waste. Although bedrock characteristics differ somewhat among the watersheds of these streams, the observed differences in water chemistry are attributed to different contaminant loadings rather than geologic variation. Water quality, radioactivity, and flow measurements are made at a number of stations operated by PORTS. Water samples were collected and analyzed at various intervals (i.e., weekly, monthly, etc.) for radiological and nonradiological parameters. During 1990 POR'TS conducted effluent-stream sampling in accordance with the National Pollutant Discharge Elimination System (NPDES) permit. (Table 3.1 summarizes the parameters and limitations; the locations of the NPDES stations are shown in Fig. 3.2.) In 1990 PORTS also conducted receiving-stream sampling, groundwater sampling and monitoring, and resident sanitary water sampling. The non-NPDES surface-water-monitoring points [i.e., routine water (RW)] are Little Beaver Creek upstream (RW12), downstream (RW7), and discharge at the north boundary line (RW8); Big Beaver Creek upstream (RW5) and downstream (RW13); Big Run Creek upstream (RW33), south boundary line (RW3), and near Wakefield (RW2); and Scioto River upstream (RW6) and downstream (RW1). See Fig. 3.3 for the locations of these sampling stations.

All plant-site liquid effluents are regulated by the NPDES permit and either discharge to surface streams that pass through the reservation or are piped directly to the Scioto River. NPDES outfalls 001, $005,006,007,008,009$, and 011 discharge to Little Beaver Creek, a tributary of Big Beaver Creek, and the Scioto River. NPDES outfalls 002 and Gas Centrifuge Enrichment Plant (GCEP) 003 discharge to Big Run Creek, which is a tributary of the Scioto River. NPDES 003 and 004 discharge directly to the Scioto River by pipeline. NPDES outfalls 010, GCEP 001, and GCEP 002 discharge to two unnamed tributaries of the Scioto River. NPDES outfalls $001 \mathrm{~A}$, 002A, 003B, 605, and 009A are internal outfalls that discharge to NPDES outfalls 001, 002, 003, 004, and 009 respectively.

The receiving streams are monitored for radioactive and nonradioactive constituents at designated RW-sampling locations. All RW locations 


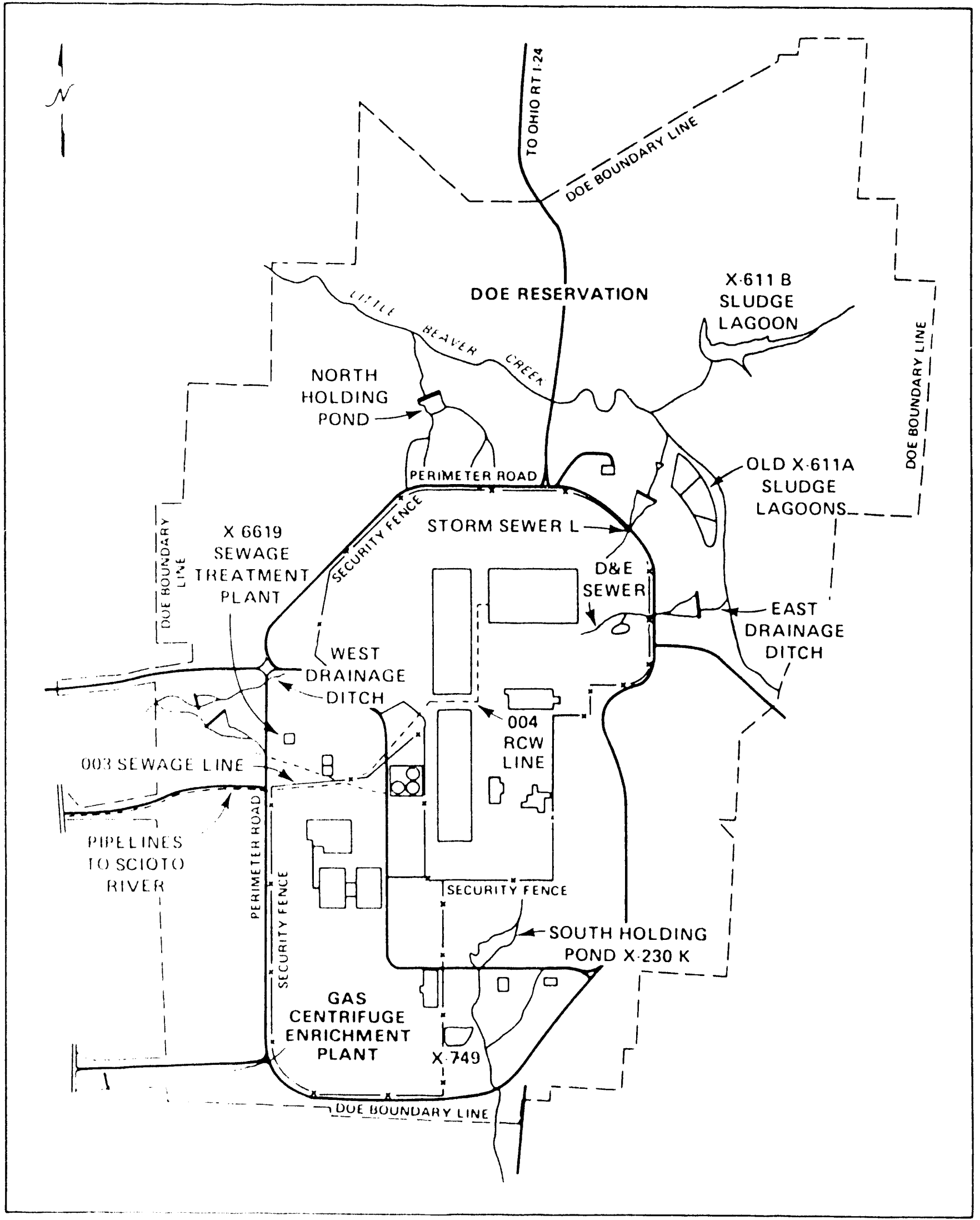

Fig. 3.1. Major wastewater sources and systems. 


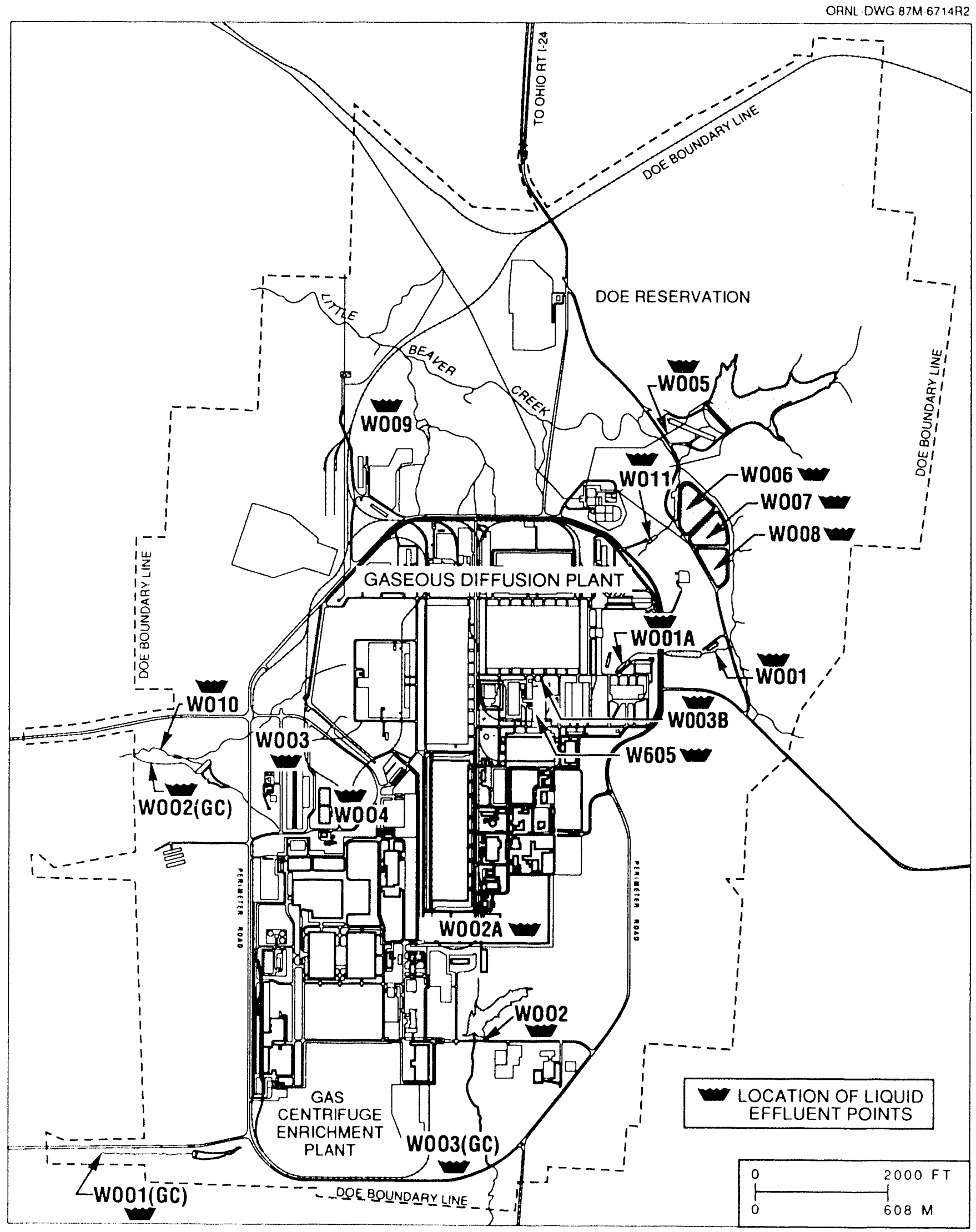

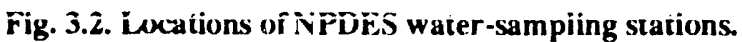


ORNL-DWG 87-10789R

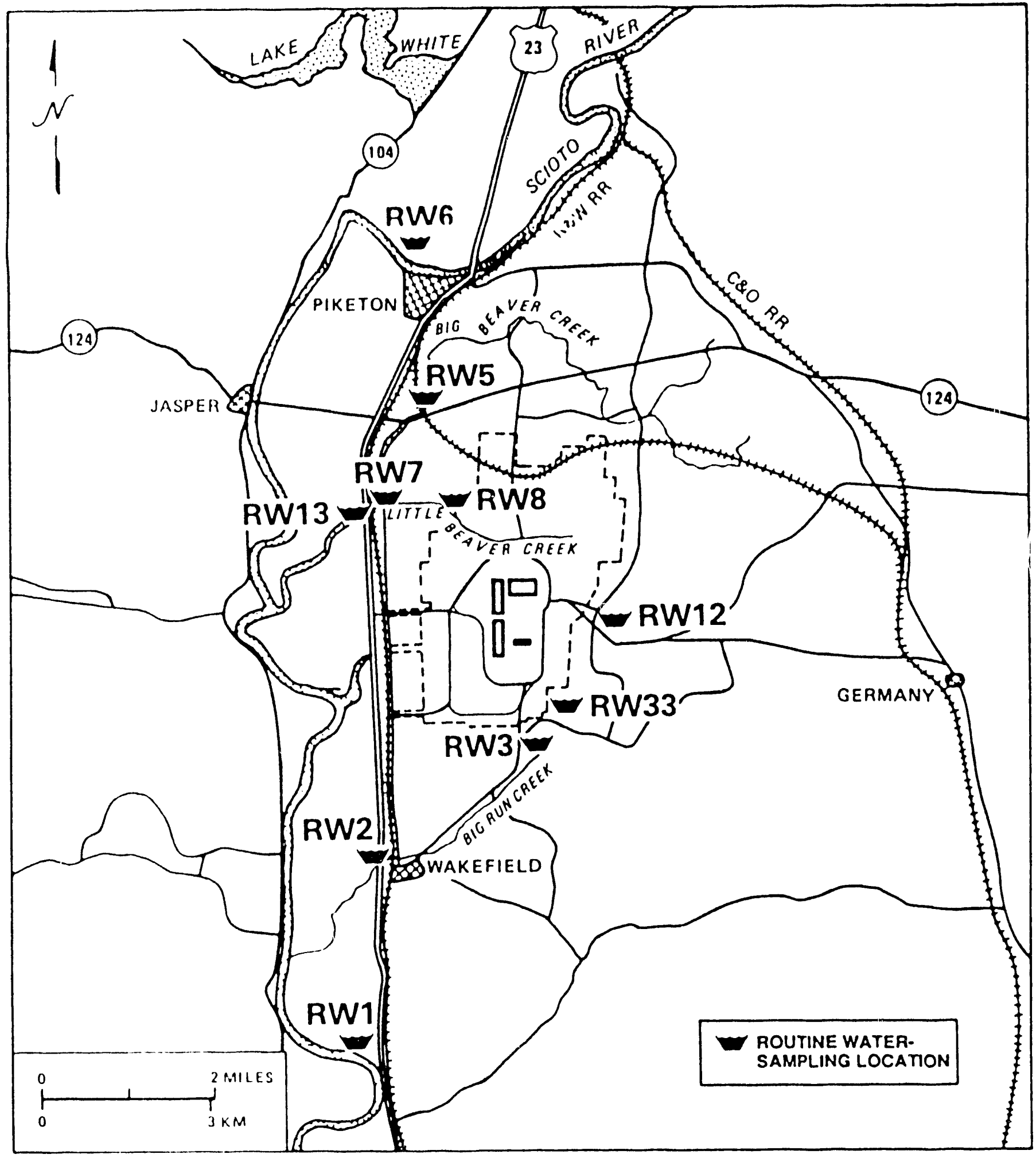

Fig. 3.3. Surface-water-sampling stations (non-NPDES). 
Table 3.1. NPDES permit-summary effective April \&, 1985

\begin{tabular}{|c|c|c|c|}
\hline $\begin{array}{l}\text { NPDES outfall description } \\
\text { and sample parameters }\end{array}$ & $\begin{array}{c}\text { Required } \\
\text { sampling method }\end{array}$ & $\begin{array}{l}\text { Daily average } \\
\text { limitation }\end{array}$ & $\begin{array}{l}\text { Daily maximum } \\
\text { limitation }\end{array}$ \\
\hline \multicolumn{4}{|c|}{ Outfall 001 (east drainage ditch) } \\
\hline $\begin{array}{l}\text { Flow } \\
\text { TSS }(\mathrm{mg} / \mathrm{L}) \\
\text { Oil and gas }(\mathrm{mg} / \mathrm{L}) \\
\text { Temperature } \\
\text { TRCL (mg/L) } \\
\text { pH }\end{array}$ & $\begin{array}{l}\text { Continuous } \\
\text { 24-h composite } \\
\text { Grab } \\
\text { Grab } \\
\text { Grab } \\
\text { Grab }\end{array}$ & $\begin{array}{l}20.00 \\
10 \\
a\end{array}$ & $\begin{array}{l}30 \\
15 \\
a \\
0.02\end{array}$ \\
\hline \multicolumn{4}{|c|}{ Outfall $001 A(601 X-701 B$ pond effluent) } \\
\hline $\begin{array}{l}\text { Flow } \\
\text { Nitrate, as } \mathrm{N} \\
\text { Ammonia, as } \mathrm{N} \\
\text { Total } \mathrm{Cu} \\
\text { Total } \mathrm{Zn}(\mathrm{kg} / \mathrm{d}) \\
\text { Total } \mathrm{Fe}(\mathrm{kg} / \mathrm{d}) \\
\text { Total } \mathrm{Ni} \\
\text { Total } \mathrm{Cr}(\mathrm{kg} / \mathrm{d}) \\
\mathrm{Cr}^{6+} \\
\text { TCE } \\
\text { pH }\end{array}$ & $\begin{array}{l}\text { Continuous } \\
\text { 24-h composite } \\
\text { 24-h composite } \\
\text { 24-h composite } \\
\text { 24-h composite } \\
\text { 24-h composite } \\
\text { 24-h composite } \\
\text { 24-h composite } \\
\text { 24-h composite } \\
\text { Grab } \\
\text { b }\end{array}$ & $\begin{array}{l}a \\
a \\
a \\
0.05 \\
0.30 \\
a \\
0.007 \\
a \\
a \\
a\end{array}$ & $\begin{array}{l}a \\
a \\
a \\
0.09 \\
0.60 \\
a \\
0.014 \\
a \\
a \\
a\end{array}$ \\
\hline \multicolumn{4}{|c|}{ Outfall 002 (X-230K, south pond effluent) } \\
\hline $\begin{array}{l}\text { Flow } \\
\text { TSS }(\mathrm{mg} / \mathrm{L}) \\
\text { TRCL }(\mathrm{mg} / \mathrm{L}) \\
\text { Oil and gas }(\mathrm{mg} / \mathrm{L}) \\
\text { pH } \\
\text { Total Fe } \\
\text { Total } \mathrm{Mn} \\
\text { Total } \mathrm{Cu} \\
\text { Total } \mathrm{Zn} \\
\text { Total } \mathrm{Ni} \\
\text { Total As }\end{array}$ & $\begin{array}{l}\text { Continuous } \\
\text { 24-h composite } \\
\text { Grab } \\
\text { Grab } \\
\text { Grab } \\
\text { 24-h composite } \\
\text { 24-h composite } \\
\text { 24-h composite } \\
\text { 24-h composite } \\
\text { 24-h composite } \\
\text { 24-h composite }\end{array}$ & $\begin{array}{l}20 \\
10 \\
a \\
a \\
a \\
a \\
a \\
a\end{array}$ & $\begin{array}{l}30 \\
0.02 \\
15 \\
\\
a \\
a \\
a \\
a \\
a \\
a\end{array}$ \\
\hline \multicolumn{4}{|c|}{ Ouffall $002 A$ (X-621 coal pile runoff treatment plant) } \\
\hline $\begin{array}{l}\text { Flow } \\
\text { TSS }(\mathrm{ing} / \mathrm{L}) \\
\text { Total } \mathrm{Fe}(\mathrm{mg} / \mathrm{L}) \\
\text { Total } \mathrm{Mn}(\mathrm{mg} / \mathrm{L}) \\
\text { Total } \mathrm{Cu} \\
\text { Total } \mathrm{Zn} \\
\text { Total } \mathrm{Ni} \\
\text { Total As } \\
\text { pH }\end{array}$ & $\begin{array}{l}\text { Continuous } \\
\text { 24-h composite } \\
\text { 24-h composite } \\
\text { 24-h composite } \\
\text { 24-h composite } \\
\text { 24-h composite } \\
\text { 24-h composite } \\
\text { 24-h composite } \\
\text { Grab }\end{array}$ & $\begin{array}{l}3.0 \\
2.0 \\
a \\
a \\
a \\
a\end{array}$ & $\begin{array}{l}50 \\
6.0 \\
4.0 \\
a \\
a \\
a \\
a\end{array}$ \\
\hline \multicolumn{4}{|c|}{ Ouffall 003 (X-6619 sewage treatment plant) } \\
\hline $\begin{array}{l}\text { Flow } \\
\text { BODs }(\mathrm{kg} / \mathrm{d}) \\
\text { TSS }(\mathrm{kg} / \mathrm{d}) \\
\text { Fecal coliform } / 100 \mathrm{~mL} \\
\text { TRCL } \\
\text { pH }\end{array}$ & $\begin{array}{l}\text { Continuous } \\
\text { 24-h composite } \\
\text { 24-h composite } \\
\text { Grab } \\
\text { 24-h composite } \\
\text { Grab }\end{array}$ & $\begin{array}{l}26.3 \\
31.8 \\
a\end{array}$ & $\begin{array}{l}40.0 \\
47.7 \\
0.5 \mathrm{mg} / \mathrm{L} \\
a\end{array}$ \\
\hline
\end{tabular}


Table 3.1 (continued)

\begin{tabular}{|c|c|c|c|}
\hline $\begin{array}{l}\text { NPDES outfall description } \\
\text { and sample parameters }\end{array}$ & $\begin{array}{c}\text { Required } \\
\text { sampling method }\end{array}$ & $\begin{array}{l}\text { Daily average } \\
\text { limitation }\end{array}$ & $\begin{array}{l}\text { Daily maximum } \\
\text { limitation }\end{array}$ \\
\hline \multicolumn{4}{|c|}{ Outfall $003 B(604$, biodenitrification plans) } \\
\hline $\begin{array}{l}\text { Flow } \\
\text { Nitrate, as } \mathrm{N}(\mathrm{kg} / \mathrm{d}) \\
\text { Total } \mathrm{Cu}(\mathrm{kg} / \mathrm{d}) \\
\text { Total } \mathrm{Zn}(\mathrm{kg} / \mathrm{d}) \\
\text { Total } \mathrm{Fe}(\mathrm{kg} / \mathrm{d}) \\
\text { Total } \mathrm{Ni}(\mathrm{kg} / \mathrm{d}) \\
\text { pH }\end{array}$ & $\begin{array}{l}\text { Continuous } \\
\text { 24-h composite } \\
\text { 24-h composite } \\
\text { 24-h composite } \\
\text { 24-h composite } \\
\text { 24-h composite } \\
\text { Grab }\end{array}$ & $\begin{array}{l}11.0 \\
0.007 \\
0.055 \\
0.23 \\
0.018\end{array}$ & $\begin{array}{l}13.0 \\
0.014 \\
0.110 \\
0.45 \\
0.036\end{array}$ \\
\hline \multicolumn{4}{|c|}{ Ouffall 605 (X-705 micro-filtration facility) } \\
\hline \multicolumn{4}{|c|}{ Outfall 004 (X-616 chromium treatment plant) } \\
\hline $\begin{array}{l}\text { Flow } \\
\text { TDS (mg/L) } \\
\text { TSS }(\mathrm{kg} / \mathrm{d}) \\
\text { Total } \mathrm{Zn}(\mathrm{kg} / \mathrm{d}) \\
\mathrm{Cr}^{6+}(\mathrm{kg} / \mathrm{d}) \\
\text { Total } \mathrm{Cr}(\mathrm{kg} / \mathrm{d}) \\
\text { Total } \mathrm{Fe}(\mathrm{kg} / \mathrm{d}) \\
\text { Total } \mathrm{Cu}(\mathrm{kg} / \mathrm{d}) \\
\text { TRCL (mg/L) } \\
\text { TCE (mg/L) } \\
\text { pH }\end{array}$ & $\begin{array}{l}\text { Con nuous } \\
\text { 24-h composite } \\
\text { 24-h composite } \\
\text { 24-h composite } \\
\text { 24-h composite } \\
\text { 24-h composite } \\
\text { 24-h composite } \\
\text { 24-h composite } \\
\text { Grab } \\
\text { 24-h composite } \\
\text { Grab }\end{array}$ & $\begin{array}{l}3500 \\
75.8 \\
1.9 \\
0.2 \\
1.9 \\
3.8 \\
1.9\end{array}$ & $\begin{array}{l}4000 \\
113.5 \\
3.8 \\
0.4 \\
3.8 \\
5.7 \\
3.8 \\
0.02 \\
0.001\end{array}$ \\
\hline \multicolumn{4}{|c|}{ Outfalls $005,006,007$, and 008 (X-611 sludge lagoons) } \\
\hline $\begin{array}{l}\text { Flow } \\
\text { TSS }(\mathrm{mg} / \mathrm{L}) \\
\mathrm{pH}\end{array}$ & $\begin{array}{l}\text { Estimate } \\
\text { Grab } \\
\text { Grab }\end{array}$ & 10 & 15 \\
\hline \multicolumn{4}{|c|}{ Outfall 009 (north holding pond) } \\
\hline Flow & $\begin{array}{l}\text { Weekly } \\
\text { measurements }\end{array}$ & & \\
\hline TSS (mg/L) & Grab & 30 & 100 \\
\hline Oil and gas (mg/L) & $G_{\text {rab }}$ & 10 & 15 \\
\hline Fluoride & Grab & $a$ & $a$ \\
\hline $\mathrm{TRCL}(\mathrm{mg} / \mathrm{L})$ & Grab & & 0.02 \\
\hline $\mathrm{pH}$ & Grab & & \\
\hline \multicolumn{4}{|c|}{ Outfall 009A (609, fluorine generator cleaning) } \\
\hline Flow & $\begin{array}{l}\text { Batch } \\
\text { measurement }\end{array}$ & & \\
\hline TSS (kg/batch) & 24-h composite & & 0.68 \\
\hline Fluorine (kg/batch) & 24-h composite & & 0.68 \\
\hline \multicolumn{4}{|c|}{ Ouffall 010 (west drainage ditch) and Outfall 011 (northeast drainage ditch) } \\
\hline $\begin{array}{l}\text { Flow } \\
\text { Oil and gas }(\mathrm{mg} / \mathrm{L}) \\
\mathrm{pH}\end{array}$ & $\begin{array}{l}\text { Continuous } \\
\text { Grab } \\
\text { Grab }\end{array}$ & 10 & 15 \\
\hline
\end{tabular}


Table 3.1 (continued)

\begin{tabular}{cccc}
\hline $\begin{array}{c}\text { NPDES outfall description } \\
\text { and sample parameters }\end{array}$ & $\begin{array}{c}\text { Required } \\
\text { sampling method }\end{array}$ & $\begin{array}{c}\text { Daily average } \\
\text { limitation }\end{array}$ & $\begin{array}{c}\text { Daily maximum } \\
\text { limitation }\end{array}$ \\
\hline
\end{tabular}

GCEP NPDES Outfalls

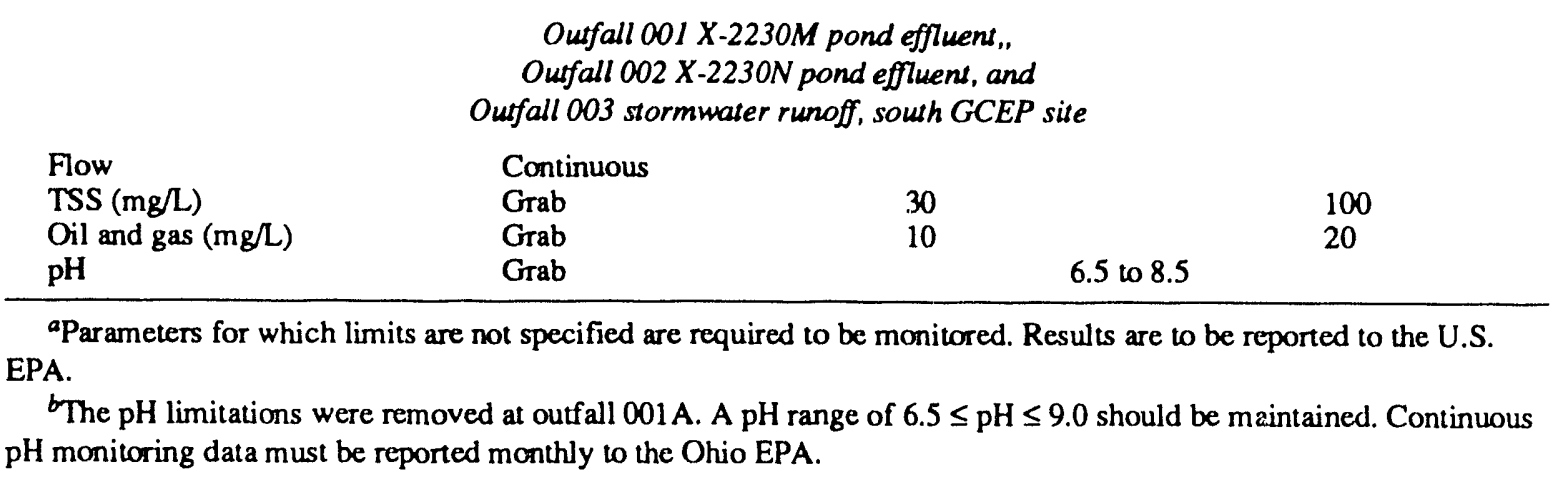

and designated NPDES outfall locations are analyzed for gross alpha and gross beta-gamma radioactivity, ${ }^{99} \mathrm{Tc}$, and uranium concentration. Part 2 of this report lists detailed sampling and analysis data. The data presented in Part 1 Tables 3.2 through 3.4 for Little Beaver Creek, Big Beaver Creek, Big Run Creek, and the Scioto River measure the impact that radioactive discharges have on these receiving streams.

The majority of nonradioactive constituents are regulated under the plant's NPDES permit, which is discussed in detail in Subsect. 3.2. The only other contaminants of concern besides radioactivity and NPDES-regulated parameters are fluorides discharged to surface waters. Fluorides are currently measured at outfalls 001 and 003 and at upstream and downstream locations in the Scioto River. The impact of all fuoride discharges from PORTS operations is negligible, as is graphically shown in Fig. 3.4.

\subsection{NATIONAL POLLUTANT DISCHARGE ELIMINATION SYSTEM MONITORING}

As is mentioned in Subsect. 3.1, the locations of NPDES monitoring points are shown in Fig. 3.2. NPDES-regulated effluent parameters and limitations are given in Table 3.1. The Ohio Environmental Protection Agency (OEPA) has regulatory authority for the CWA at PORTS. OEPA, however, did not become active in administering NPDES permits to federal facilities until early 1983. In a letter from
OEPA dated May 25, 1983, PORTS was advised to begin reporting monthly self-monitoring NPDES reports directly to OEPA beginning with the August 1983 report.

In December 1983, and again in December 1984, the Southeast District Office of the OEPA conducted compliance inspections of PORTS. These compliance inspections led to the issuance of the Director's Findings and Orders, effective April 8, 1985. The findings indicated that PORTS has failed to maintain compliance in accordance with the second-round NPDES permit at NPDES outfalls $601(001 \mathrm{~A}$, the $X-701 B$ holding pond) and 604 (003B, the biodenitrification pilot plant). The Orders relaxed overly stringent effluent limits at outfall 601 (the $X-701 B$ holding pond) and outfall 604 (the biodenitrification facility) and established a schedule for constructing additional treatment facilities at these outfalls.

The current NPDES permit is thus the second-round permit issued in 1980 with revisions described in the Director's Findings and Orders. The first official meeting on the third-round NPDES permit was held with OEPA in November 1986. Details on EPA's effluent sampling and inspection study, Best Management Practice (BMP) Guidelines, and other permitting details were discussed. After much negotiation and coordination, a draft NPDES permit was given public notice in July 1988. All comments to the draft permit have been received, and 
Table 3.2. 1990 gross alpha radioactivity in water samples

\begin{tabular}{|c|c|c|c|c|c|}
\hline \multirow{2}{*}{$\begin{array}{l}\text { Sample } \\
\text { location }\end{array}$} & \multirow{2}{*}{$\begin{array}{l}\text { Number of } \\
\text { samples }\end{array}$} & \multicolumn{3}{|c|}{ Concentration $(\mathrm{pCi} / \mathrm{L})$} & \multirow{2}{*}{$\begin{array}{l}\text { Standard } \\
\text { deviation }\end{array}$} \\
\hline & & $\operatorname{Max}$ & Min & Av & \\
\hline \multicolumn{6}{|c|}{ GDP ouffalls ${ }^{a}$} \\
\hline $\begin{array}{l}001 \\
002 \\
003 \\
004 \\
009 \\
010 \\
011 \\
605\end{array}$ & $\begin{array}{l}48 \\
52 \\
51 \\
52 \\
51 \\
50 \\
51 \\
51\end{array}$ & $\begin{array}{r}1,314.0 \\
19.8 \\
810.0 \\
95.0 \\
19.4 \\
57.0 \\
15.8 \\
180,079.0\end{array}$ & $\begin{array}{r}9.0 \\
-6.0 \\
9.0 \\
-14.0 \\
-3.0 \\
0.0 \\
6.0 \\
990.0\end{array}$ & $\begin{array}{r}129.50 \\
3.61 \\
200.40 \\
7.78 \\
8.64 \\
8.85 \\
2.63 \\
22,338.00\end{array}$ & $\begin{array}{r}252.30 \\
3.75 \\
149.50 \\
15.82 \\
4.15 \\
8.12 \\
3.47 \\
32,657.00\end{array}$ \\
\hline \multicolumn{6}{|c|}{ GCEP ouffalls ${ }^{b}$} \\
\hline $\begin{array}{l}001 \\
002 \\
003\end{array}$ & $\begin{array}{r}11 \\
9 \\
5\end{array}$ & $\begin{array}{r}5.4 \\
14.4 \\
9.9\end{array}$ & $\begin{array}{l}0.0 \\
0.0 \\
2.0\end{array}$ & $\begin{array}{l}1.88 \\
3.18 \\
5.97\end{array}$ & $\begin{array}{l}1.56 \\
4.13 \\
3.23\end{array}$ \\
\hline \multicolumn{6}{|c|}{ Little Beaver Creek } \\
\hline $\begin{array}{l}\text { RW7 } \\
\text { RW8 } \\
\text { RW12 }\end{array}$ & $\begin{array}{l}11 \\
52 \\
11\end{array}$ & $\begin{array}{r}93.6 \\
644.0 \\
1.0\end{array}$ & $\begin{array}{r}4.1 \\
9.9 \\
-2.0\end{array}$ & $\begin{array}{r}31.41 \\
72.52 \\
0.06\end{array}$ & $\begin{array}{r}23.06 \\
102.80 \\
0.90\end{array}$ \\
\hline \multicolumn{6}{|c|}{ Big Beaver Creek } \\
\hline $\begin{array}{l}\text { RW5 } \\
\text { RW13 }\end{array}$ & $\begin{array}{l}11 \\
11\end{array}$ & $\begin{array}{l}97.2 \\
72.0\end{array}$ & $\begin{array}{r}-1.0 \\
2.3\end{array}$ & $\begin{array}{l}58.00 \\
21.58\end{array}$ & $\begin{array}{l}73.00 \\
19.17\end{array}$ \\
\hline \multicolumn{6}{|c|}{ Big Run Creek } \\
\hline $\begin{array}{l}\text { RW2 } \\
\text { RW3 } \\
\text { RW33 }\end{array}$ & $\begin{array}{l}11 \\
11 \\
11\end{array}$ & $\begin{array}{r}7.2 \\
10.0 \\
2.7\end{array}$ & $\begin{array}{l}-1.0 \\
-1.0 \\
-2.0\end{array}$ & $\begin{array}{l}1.46 \\
3.51 \\
0.28\end{array}$ & $\begin{array}{l}2.11 \\
2.82 \\
1.12\end{array}$ \\
\hline \multicolumn{6}{|c|}{ Scioto River } \\
\hline $\begin{array}{l}\mathrm{RW} 1 \\
\mathrm{RW6}\end{array}$ & $\begin{array}{l}50 \\
50\end{array}$ & $\begin{array}{l}32.0 \\
36.0\end{array}$ & $\begin{array}{l}-3.0 \\
-1.0\end{array}$ & $\begin{array}{l}3.10 \\
4.50\end{array}$ & $\begin{array}{l}4.70 \\
6.63\end{array}$ \\
\hline
\end{tabular}

${ }^{a}$ Gaseous Diffusion Plant.

${ }^{b}$ Gas Centrifuge Enrichment Plant. 
Table 3.3. 1990 beta-gamma radioactivity in water samples

\begin{tabular}{|c|c|c|c|c|c|c|}
\hline \multirow{2}{*}{$\begin{array}{l}\text { Sample } \\
\text { location }\end{array}$} & \multirow{2}{*}{$\begin{array}{l}\text { Number of } \\
\text { samples }\end{array}$} & \multirow{2}{*}{ Radionuclide } & \multicolumn{3}{|c|}{ Concentration (pCi/L) } & \multirow{2}{*}{$\begin{array}{l}\text { Standard } \\
\text { deviation }\end{array}$} \\
\hline & & & $\operatorname{Max}$ & Min & $\mathrm{Av}$ & \\
\hline \multicolumn{7}{|c|}{$G D P$ ouffalls ${ }^{a}$} \\
\hline 001 & 51 & ${ }^{234} \mathrm{Th}$ & 198 & -17 & 31.9 & 42.3 \\
\hline 001 & 50 & ${ }^{99} \mathrm{Tc}$ & 194 & 3 & 58.9 & 29.0 \\
\hline 002 & 52 & ${ }^{234} \mathrm{Th}$ & 63 & -8 & 8.6 & 10.5 \\
\hline 002 & 52 & ${ }^{99} \mathrm{Tc}$ & 43 & -9 & 7.5 & 8.8 \\
\hline 003 & 51 & ${ }^{234} \mathrm{Th}$ & 485 & -12 & 109.2 & 114.7 \\
\hline 003 & 51 & ${ }^{99} \mathrm{Tc}$ & 765 & 4 & 242.6 & 136.7 \\
\hline 004 & 52 & ${ }^{234} \mathrm{Th}$ & 8,941 & 34 & 361.0 & $1,217.0$ \\
\hline 004 & 52 & ${ }^{99} \mathrm{Tc}$ & 19,812 & 14 & 649.0 & $2,712.0$ \\
\hline 009 & 51 & ${ }^{234} \mathrm{Th}$ & 38 & -6 & 10.0 & 8.0 \\
\hline 009 & 51 & ${ }^{99} \mathrm{Tc}$ & 32 & -2 & 7.6 & 6.5 \\
\hline 010 & 50 & ${ }^{234} \mathrm{Th}$ & 107 & -7 & 10.2 & 15.4 \\
\hline 010 & 50 & ${ }^{99} \mathrm{Tc}$ & 40 & -2 & 6.0 & 6.4 \\
\hline 011 & 51 & ${ }^{234} \mathrm{Th}$ & 15 & -6 & 4.5 & 4.9 \\
\hline 011 & 51 & ${ }^{99} \mathrm{Tc}$ & 20 & -6 & 5.2 & 5.4 \\
\hline 605 & 41 & ${ }^{234} \mathrm{Th}$ & 10,841 & -84 & $1,998.0$ & $2,380.0$ \\
\hline 605 & 51 & ${ }^{99} \mathrm{Tc}$ & $9,381,520$ & 273 & $254,644.0$ & $1,303,493.0$ \\
\hline \multicolumn{7}{|c|}{ GCEP outfalls $s^{b}$} \\
\hline 001 & 11 & ${ }^{234} \mathrm{Th}$ & 11 & -2 & 3.0 & 3.9 \\
\hline 001 & 11 & ${ }^{99} \mathrm{Tc}$ & 15 & 0 & 5.8 & 4.0 \\
\hline 002 & 9 & ${ }^{234} \mathrm{Th}$ & 25 & -5 & 6.9 & 8.9 \\
\hline 002 & 9 & ${ }^{99} \mathrm{Tc}$ & 10 & 0 & 5.3 & 3.4 \\
\hline 003 & 5 & ${ }^{234} \mathrm{Th}$ & 34 & 2 & 15.4 & 10.6 \\
\hline 003 & 5 & ${ }^{99} \mathrm{Tc}$ & 14 & 1 & 6.4 & 4.5 \\
\hline \multicolumn{7}{|c|}{ Little Beaver Creek } \\
\hline RW7 & 11 & ${ }^{234} \mathrm{Th}$ & 77 & 17 & 37.6 & 18.2 \\
\hline RW7 & 11 & ${ }^{99} \mathrm{Tc}$ & 53 & 4 & 31.5 & 14.6 \\
\hline RW8 & 52 & ${ }^{234} \mathrm{Th}$ & 110 & 6 & 42.4 & 21.0 \\
\hline RW8 & 52 & ${ }^{99} \mathrm{Tc}$ & 64 & 14 & 32.8 & 42.4 \\
\hline RW12 & 11 & ${ }^{234} \mathrm{Th}$ & 25 & -5 & 11.4 & 10.6 \\
\hline RW12 & 11 & ${ }^{99} \mathrm{Tc}$ & 17 & -4 & 5.3 & 6.5 \\
\hline \multicolumn{7}{|c|}{ Big Beaver Creek } \\
\hline RW5 & 11 & ${ }^{234} \mathrm{Th}$ & 73 & -6 & 8.0 & 20.9 \\
\hline RW5 & 11 & ${ }^{99} \mathrm{Tc}$ & 58 & 0 & 11.2 & 15.7 \\
\hline RW13 & 11 & ${ }^{234} \mathrm{Th}$ & 61 & -6 & 23.7 & 16.8 \\
\hline RW13 & 11 & ${ }^{99} \mathrm{Tc}$ & 45 & 2 & 21.9 & 12.0 \\
\hline \multicolumn{7}{|c|}{ Big Run Creek } \\
\hline RW2 & 11 & ${ }^{234} \mathrm{Th}$ & 11 & -8 & 3.5 & 5.3 \\
\hline RW2 & 11 & ${ }^{99} \mathrm{Tc}$ & 13 & 3 & 7.0 & 3.5 \\
\hline RW3 & 11 & ${ }^{234} \mathrm{Th}$ & 16 & -4 & 4.7 & 6.5 \\
\hline RW3 & 11 & ${ }^{99} \mathrm{Tc}$ & 18 & -3 & 7.6 & 5.7 \\
\hline RW33 & 11 & ${ }^{234} \mathrm{Th}$ & 10 & -8 & 4.5 & 5.1 \\
\hline RW33 & 11 & ${ }^{99} \mathrm{Tc}$ & 12 & -1 & 5.8 & 4.4 \\
\hline
\end{tabular}


Table 3.3 (Continued)

\begin{tabular}{|c|c|c|c|c|c|c|}
\hline \multirow{2}{*}{$\begin{array}{l}\text { Sample } \\
\text { location }\end{array}$} & \multirow{2}{*}{$\begin{array}{c}\text { Number of } \\
\text { samples }\end{array}$} & \multirow{2}{*}{ Radionuclide } & \multicolumn{3}{|c|}{ Concentration $(\mathrm{pCi} / \mathrm{L})$} & \multirow{2}{*}{$\begin{array}{l}\text { Standard } \\
\text { deviation }\end{array}$} \\
\hline & & & $\operatorname{Max}$ & $\operatorname{Min}$ & $A v$ & \\
\hline
\end{tabular}

\begin{tabular}{lllllrr}
\multicolumn{5}{c}{ Scioto River } \\
RW1 & 50 & ${ }^{234} \mathrm{Th}$ & 24 & -8 & 6.4 & 5.6 \\
RW1 & 50 & ${ }^{99} \mathrm{Tc}$ & 99 & -6 & 7.7 & 14.8 \\
RW6 & 50 & ${ }^{234} \mathrm{Th}$ & 24 & -8 & 7.0 & 6.5 \\
RW6 & 50 & ${ }^{99} \mathrm{Tc}$ & 31 & -4 & 6.4 & 6.7 \\
\hline
\end{tabular}

${ }^{a}$ Gaseous Diffusion Plant.

${ }^{b}$ Gas Centrifuge Enrichment Plant.

OEPA is in the process of responding to all comments. Further negotiations were held in March 1989 and on several occasions in CY 1990. A new permit is expected to be issued by mid-1991.

\subsubsection{Description of NPDES-Regulated Outfalls}

The following is a listing of all permitted discharge outfalls at PORTS and a brief description of each.

\section{Portsmouth Gaseous Diffusion Plant (OH0006092)}

NPDES 001 (X-230J-7) east drainage ditch. The $\mathrm{X}-230 \mathrm{~J}-7$ holding pond provides a quiescent zone for settling of suspended solids, dissipation of chlorine, and oil diversion and containment. A flow diagram for 001 is given in Fig. 3.5.

NPDES 001A (601) X-701B holding pond. The $\mathrm{X}-701 \mathrm{~B}$ holding pond provides $\mathrm{pH}$ adjustment with slaked lime, settling of heavy metals, and containment of oil with use of oil booms. A flow diagram for $001 \mathrm{~A}$ is given in Fig. 3.5.

NPDES 002 (X-230K) south holding pond. The south holding pond provides a quiescent zone for settling of suspended solids and dissipation of chlorine, followed by final $\mathrm{pH}$ adjustments before discharge. A flow diagram for 002 is given in Fig. 3.6.

NPDES 002A (602) X-621 coal pile treatment plant. The X-621 coal pile treatment plant provides a lagoon for collecting and equalizing coal pile runoff and steam plant cooling water. The collected water is then $\mathrm{pH}$ adjusted, and suspended solids are removed using a lamella settler. Sludge is dewatered using a pressure filter. Other steam plant waste streams that originally were sent to the X-621 facility are now treated separately and sent directly to the south holding pond. Water-softening regeneration water is treated using $\mathrm{pH}$ adjustment, ash wash water is treated for solids removal using a pressure filter, and steam plant boiler blowdown water is sent to the south holding pond untreated. A flow diagram for 002A is given in Fig. 3.6.

NPDES $003(X-6619)$ sewage treatment plant.

The X-6619 sewage treatment plant uses screening and a grit chamber as preliminary treatment followed by an activated sludge treatment system. Mixed liquid from the aeration basins is clarified, filtered using multimedia sand filters, and then chlorinated. Sludge is aerobically digested and dried on sludge drying beds. A flow diagram for 003 is given in Fig. 3.7.

NPDES 003A (603) X-710 laboratory treatment facility (canceled). In lieu of constructing a separate treatment facility to treat laboratory wastes, OEPA suggested administrative controls to minimize the discharge of organics and metals. Administrative controls are currently being practiced, and all remaining laboratory wastes are treated at the X-6619 sewage treatment facility. The OEPA has officially agreed to cancellation of the proposed project. A flow diagram for $003 \mathrm{~A}$ is given in Fig. 3.7.

NPDES 003B (604) biodenitrification plant. The existing biodenitrification plant is an actual pilot plant transferred to PORTS from Oak Ridge, Tennessee. Construction of a full-scale plant was completed in early CY 1987 , and operational startup was initiated in May 1987. Both the pilot plant and the full-scale plant have continued to operate through CY 1990. Raffinate is treated to remove heavy metals using a pressure filter, technetium is removed by ion exchange, and the remaining high-nitrate solution is diluted and treated biologically using a fluidized-bed coal media reactor. Bacteria and minor coal fines are 
Table 3.4. 1990 uranium in water samples

\begin{tabular}{|c|c|c|c|c|c|}
\hline \multirow{2}{*}{$\begin{array}{l}\text { Sample } \\
\text { location }\end{array}$} & \multirow{2}{*}{$\begin{array}{l}\text { Number of } \\
\text { samples }\end{array}$} & \multicolumn{3}{|c|}{ Concentration $(\mu \mathrm{g} / \mathrm{L})$} & \multirow{2}{*}{$\begin{array}{l}\text { Standard } \\
\text { deviation }\end{array}$} \\
\hline & & $\operatorname{Max}$ & Min & Av & \\
\hline \multicolumn{6}{|c|}{ GDP outfalls ${ }^{a}$} \\
\hline 001 & 52 & 138 & 1 & 12 & 23 \\
\hline 002 & 52 & 5 & $<1$ & $<1$ & 1 \\
\hline 003 & 52 & 44 & 1 & 20 & 11 \\
\hline 004 & 52 & 18 & $<1$ & $<2$ & 3 \\
\hline 009 & 51 & 15 & $<2$ & $<9$ & 3 \\
\hline 010 & 51 & 18 & 1 & 8 & 4 \\
\hline 011 & 52 & 24 & $<1$ & $<2$ & 4 \\
\hline 605 & 51 & 19,400 & 140 & 3,197 & 3,958 \\
\hline \multicolumn{6}{|c|}{ GCEP outfalls ${ }^{b}$} \\
\hline 001 & 12 & 2 & $<1$ & $<1$ & 0 \\
\hline 002 & 11 & 2 & $<1$ & $<1$ & 0 \\
\hline 003 & 5 & 3 & $<1$ & $<2$ & 1 \\
\hline \multicolumn{6}{|c|}{ Little Beaver Creek } \\
\hline RW7 & 11 & 12 & 1 & 4 & 2 \\
\hline RW8 & 52 & 46 & 1 & 7 & 7 \\
\hline RW12 & 11 & $<1$ & $<1$ & $<1$ & N/A \\
\hline \multicolumn{6}{|c|}{ Big Beaver Creek } \\
\hline RW5 & 11 & 15 & $<1$ & $<2$ & 4 \\
\hline RW13 & 11 & 11 & $<1$ & $<3$ & 2 \\
\hline \multicolumn{6}{|c|}{ Big Run Creek } \\
\hline $\mathrm{RW} 2$ & 11 & 1 & $<1$ & $<1$ & N/A \\
\hline RW3 & 11 & 2 & $<1$ & $<1$ & 0 \\
\hline RW33 & 11 & 3 & $<1$ & $<1$ & 0 \\
\hline \multicolumn{6}{|c|}{ Scioto River } \\
\hline RW1 & 50 & 5 & $<1$ & $<2$ & 1 \\
\hline RW6 & 50 & 4 & $<1$ & $<1$ & 0 \\
\hline
\end{tabular}

${ }^{a}$ Gaseous Diffusion Plant.

${ }^{b}$ Gas Centrifuge Enrichment Plant. 

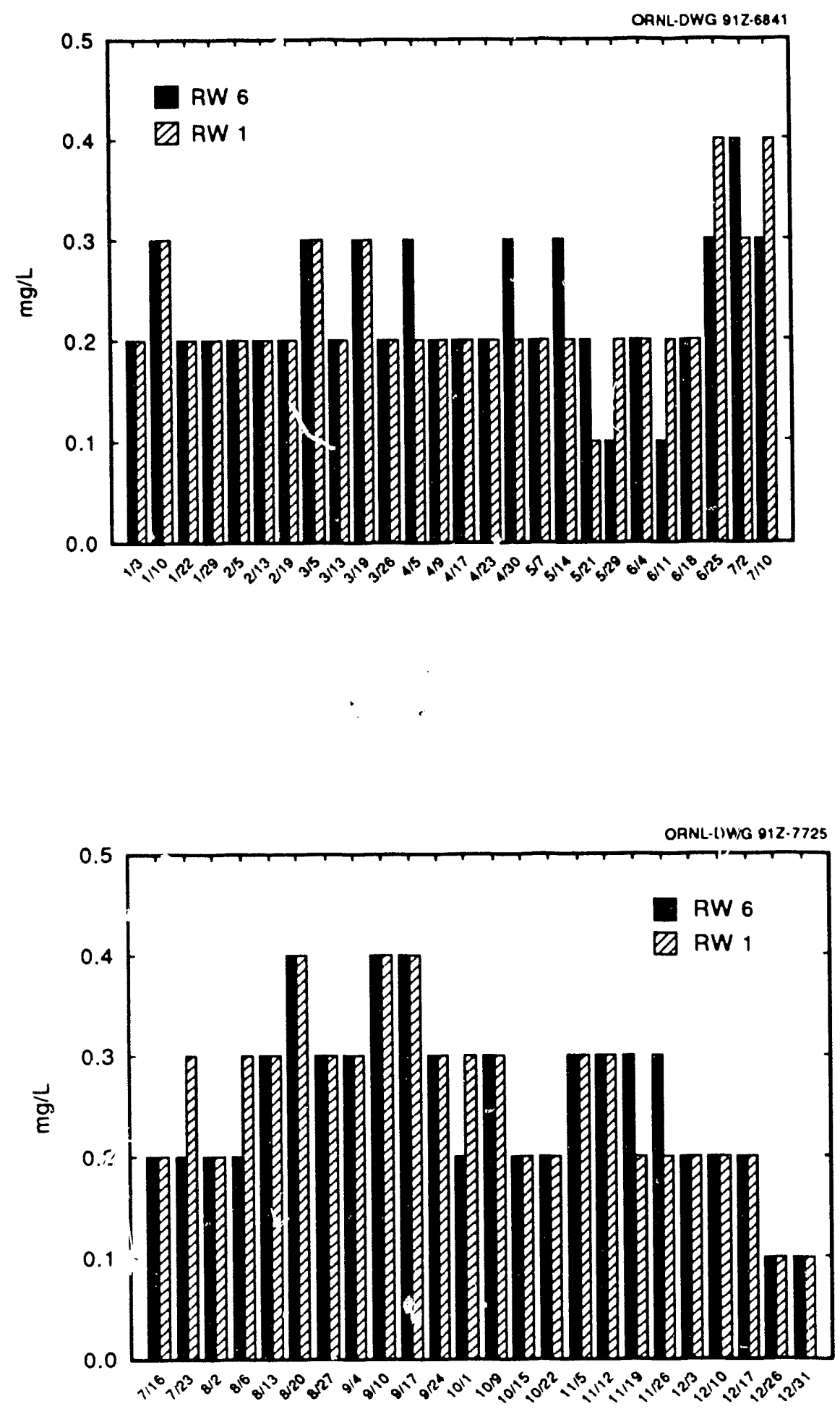

Fig. 3.4. i 990 fluoride concentrations 


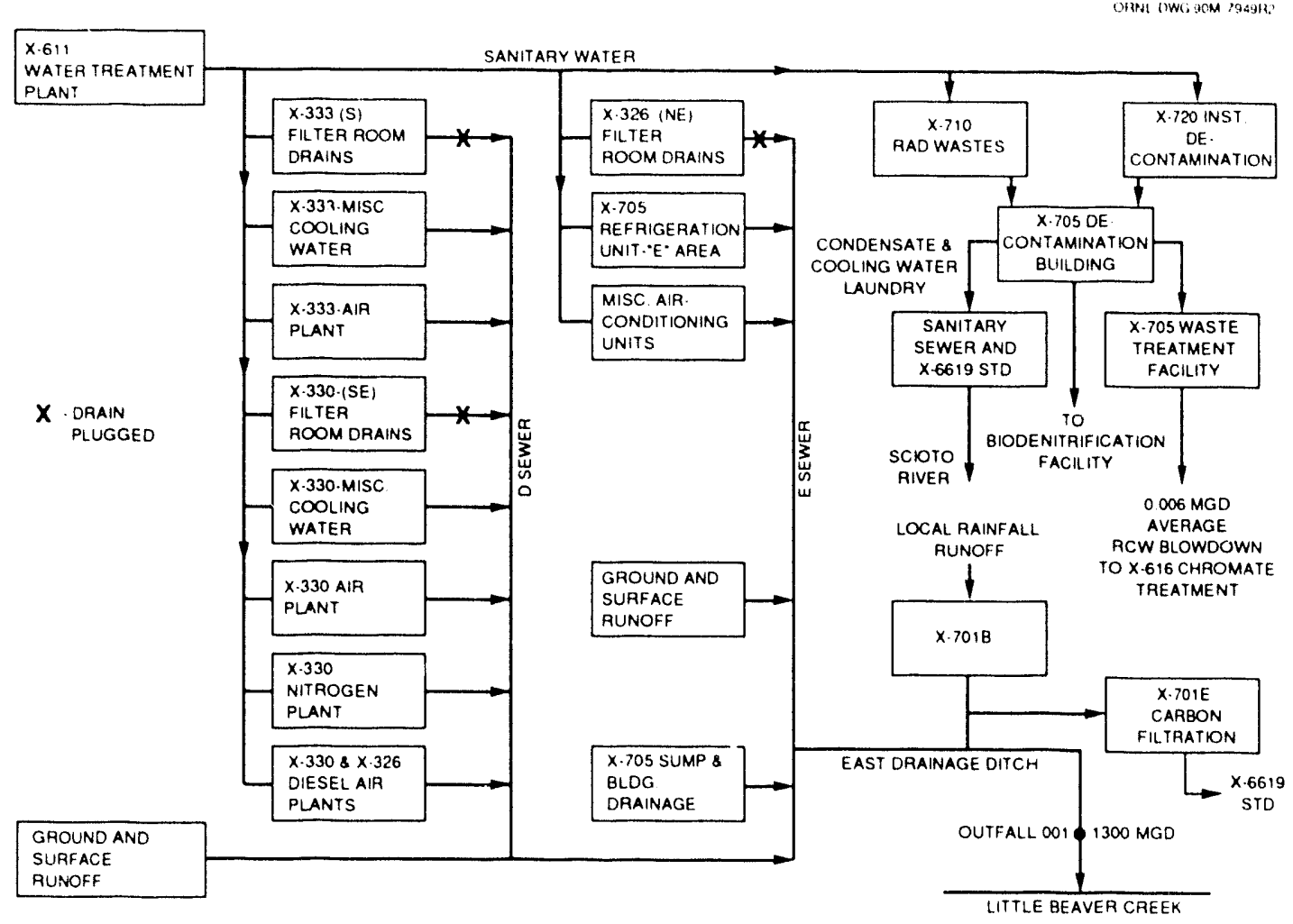

Fig. 3.5. Outfalls 001 and $001 \mathrm{~A}$ flow dlagram.

ORNL OWG 87M 8230 R2

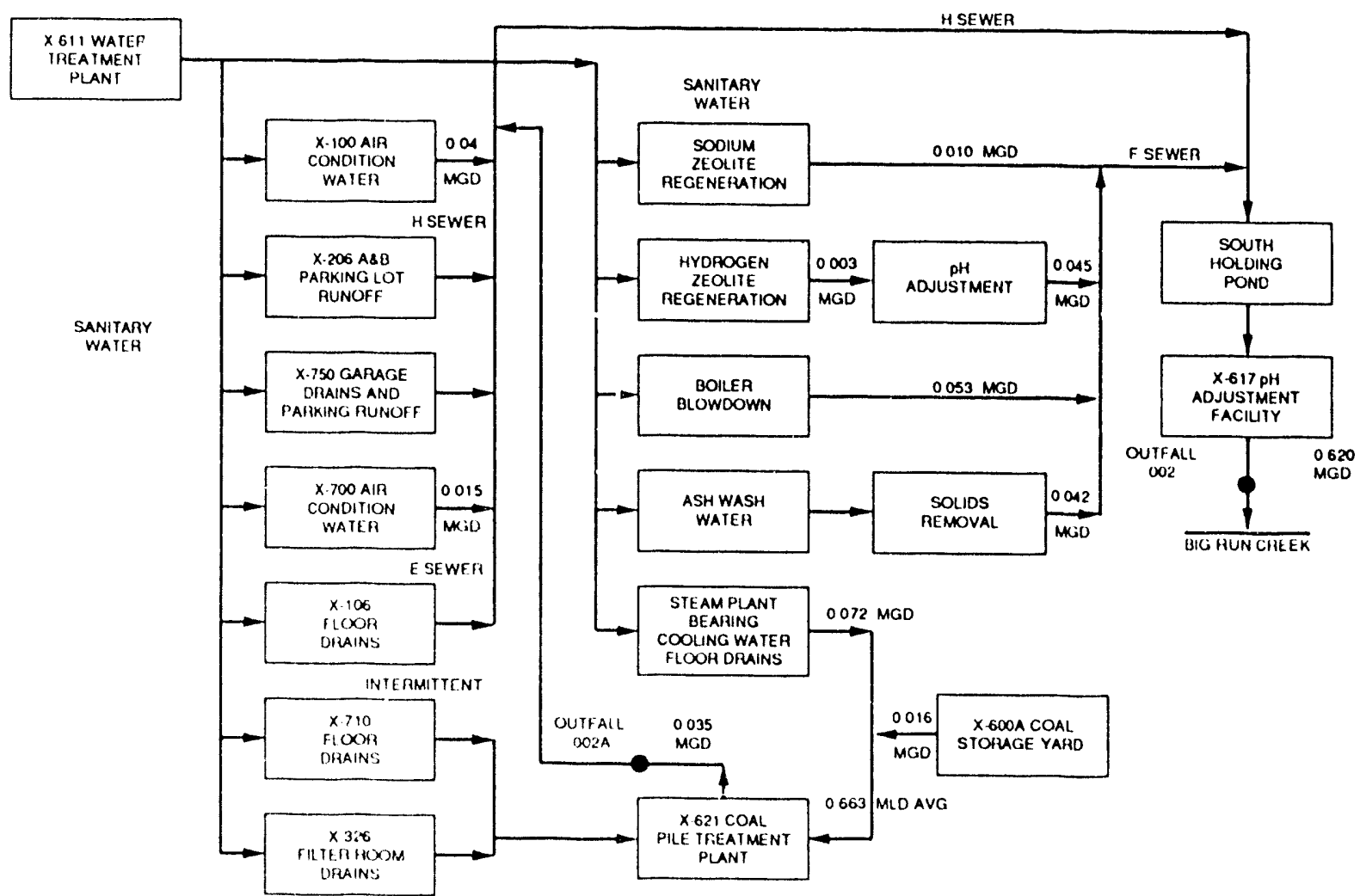

Fig. 3.6. Outfalls 002 and $002 \mathrm{~A}$ flow diagram. 
discharged to the X-6619 sewage treatment facility. A flow diagram for 003B is given in Fig. 3.7.

NPDES 004 (X-616) chromate treatment facility. $\mathrm{RCW}$ blowdown containing hexavalent chromium first is reduced to trivalent chromium using sulfurous acid. Slaked lime is added to raise $\mathrm{pH}$, and the trivalent chromium hydroxide sludge is clarified before discharge. Sludge is currently treated, filtered, and stored, and supernatant is returned to the treatment plant influent. Following treatment, the sludge is no longer RCRA hazardous. A flow diagram for 004 is given in Fig. 3.8.

NPDES $605(X-705)$ waste treatment facility. In November 1988 the X-701B holding pond (NPDES $601)$ was eliminated and replaced with the new X-705 waste treatment facility to treat all X-705 wastewater. All process wastewaters are collected, stored, treated for oil and grease, and then further treated using microfiltration and pressure filtration technology. Discharge is to the RCW blowdown line, which ultimately discharges to the X-616 chromate treatment facility (NPDES 004) and the Scioto River. A flow diagram for 605 is given in Fig. 3.8.

NPDES $005(X-611 B)$ sludge lagoon. The $X-611 B$ sludge lagoon provides a quiescent zone for settling lime sludge used in the water system softening process and receives rainfall runoff. Supernatant is returned to the water treatment plant. A discharge from this facility is rare and occurs only during periods of excessive rainfall. A flow diagram for 005 is given in Fig. 3.9.

NPDES $006(X-611 A)$ north sludge lagoon. NPDES 007 (X-611A) middle sludge lagoon, and NPDES $008(X-611 A)$ south sludge lagoon. These lagoons once received lime sludge from the plant's water-softening process and are filled to capacity. The lagoons now receive only rainfall runoff. $A$ discharge from these facilities is rare and occurs only during periods of excessive rainfall. Flow diagrams for 006, 007, and 008 are given in Fig. 3.9.

NPDES $009(X-230 L)$ north holding pond. The north holding pond provides a quiescent zone for settling of suspended solids and dissipation of chlorine. The pond can be closed for emergency containment of unpermitted discharges. A flow diagram for 009 is given in Fig. 3.10.

NPDES 009A (609) fluorine generator cleaning. The fluorine generator cleaning pit provides a sand and gravel settling pit for settling and filtering
pH-adjusted cleaning solution solids prior to discharge to the north holding pond. Because of a reduction in plant activity in this area, a discharge from this outfall is very rare. Since 1982 there have been no discharges from this outfall. A flow diagram for 009A is given in Fig. 3.10.

NPDES $010(X-230 J-5)$ west drainage ditch. The $X-230 \mathrm{~J}-5$ holding pond provides a quiescent zone for settling suspended solids, dissipation of chlorine, and oil diversion and containment. A flow diagram for 010 is given in Fig. 3.11.

NPDES 011 (X-230J-6) northeast drainage ditch. The X-230J-6 holding pond provides a quiescent zone for settling of suspended solids, dissipation of chlorine, and oil diversion and containment. A flow diagram for 011 is given in Fig. 3.12.

\section{Portsmouth Gas Centrifuge Enrichment Plant (OH0110931)}

GCEP 001 (X-2230M) holding pond No. 1. The $\mathrm{X}-2230 \mathrm{M}$ holding pond provides a quiescent zone for settling of suspended solids, dissipation of chlorine, and containment of oil with effluent baffling.

GCEP 002 (X-2230N) holding pond No. 2. The $\mathrm{X}-2230 \mathrm{~N}$ holding pond provides a quiescent zone for settling of suspended solids, dissipation of chlorine, and containment of oil with effluent baffling.

GCEP 003 (holding pond not constructed). A holding pond originally designated as outfall 003 was never constructed because of significant changes in the area topography. NPDES sampling in the remaining small drainage sector has continued, however, when a measurable flow occurs during periods of excessive rainfall. A flow diagram for these outfalls is given in Fig. 3.13.

\subsubsection{NPDES Radiological Summary}

Summary bar charts for plant-site radioactive discharges are shown in Figs. 3.14 through 3.17. These charts depict the 5-year trend for the discharge of uranium (in $\mathrm{Ci}$ and $\mathrm{kg} \mathrm{U}$ ), ${ }^{99} \mathrm{Tc}$, and uranium daughters discharged to surface waters through NPDES outfalls. Radiological data by individual outfall locations are also given in Tables 3.2 through 3.4. These data are given on a concentration basis for total alpha and beta-gamma radioactivity and total uranium. See Table 3.2 of Part 2 of this report for detailed sampling and analyses of all locations. 


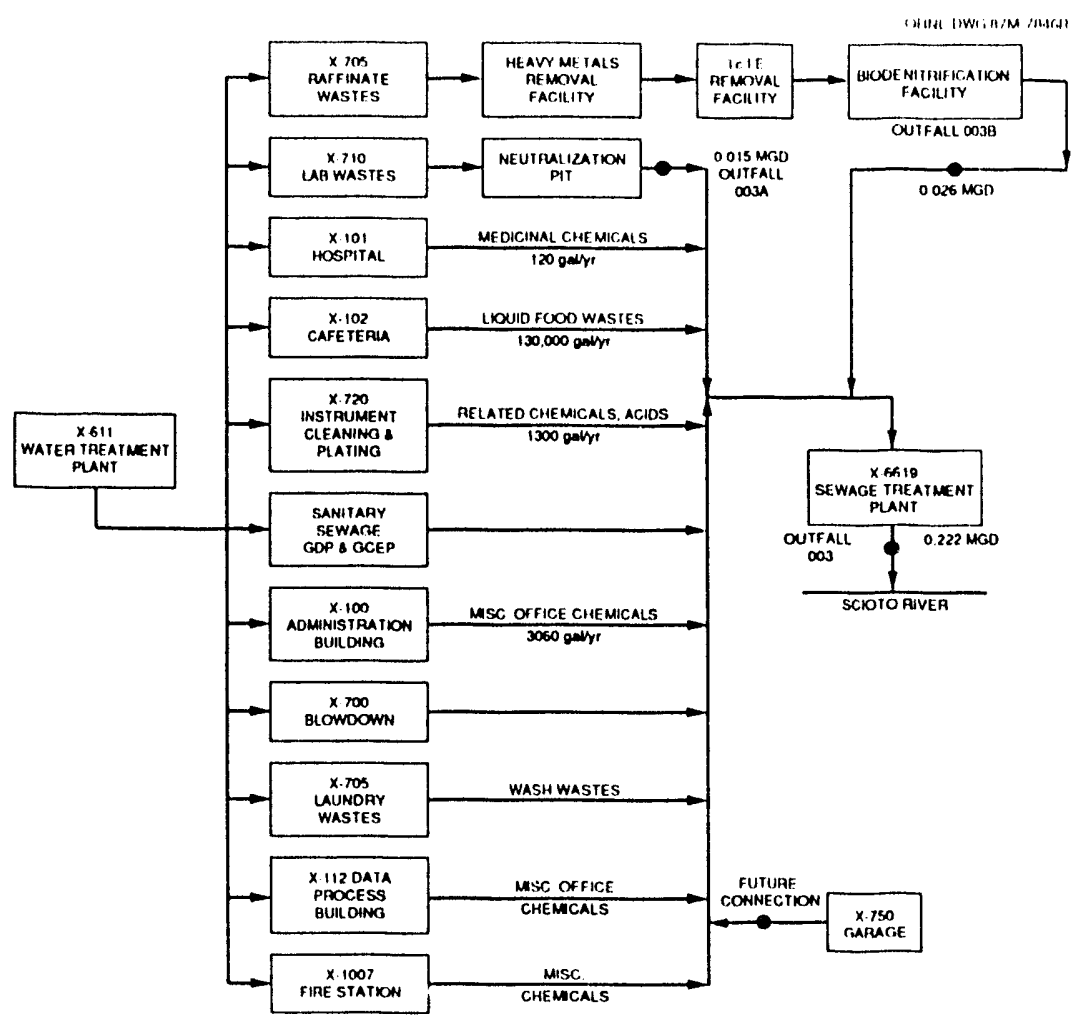

Fig. 3.7. Outfalls 003, 003A, and 003B flow diagram.

ORNL.DWG 87M-7847R2

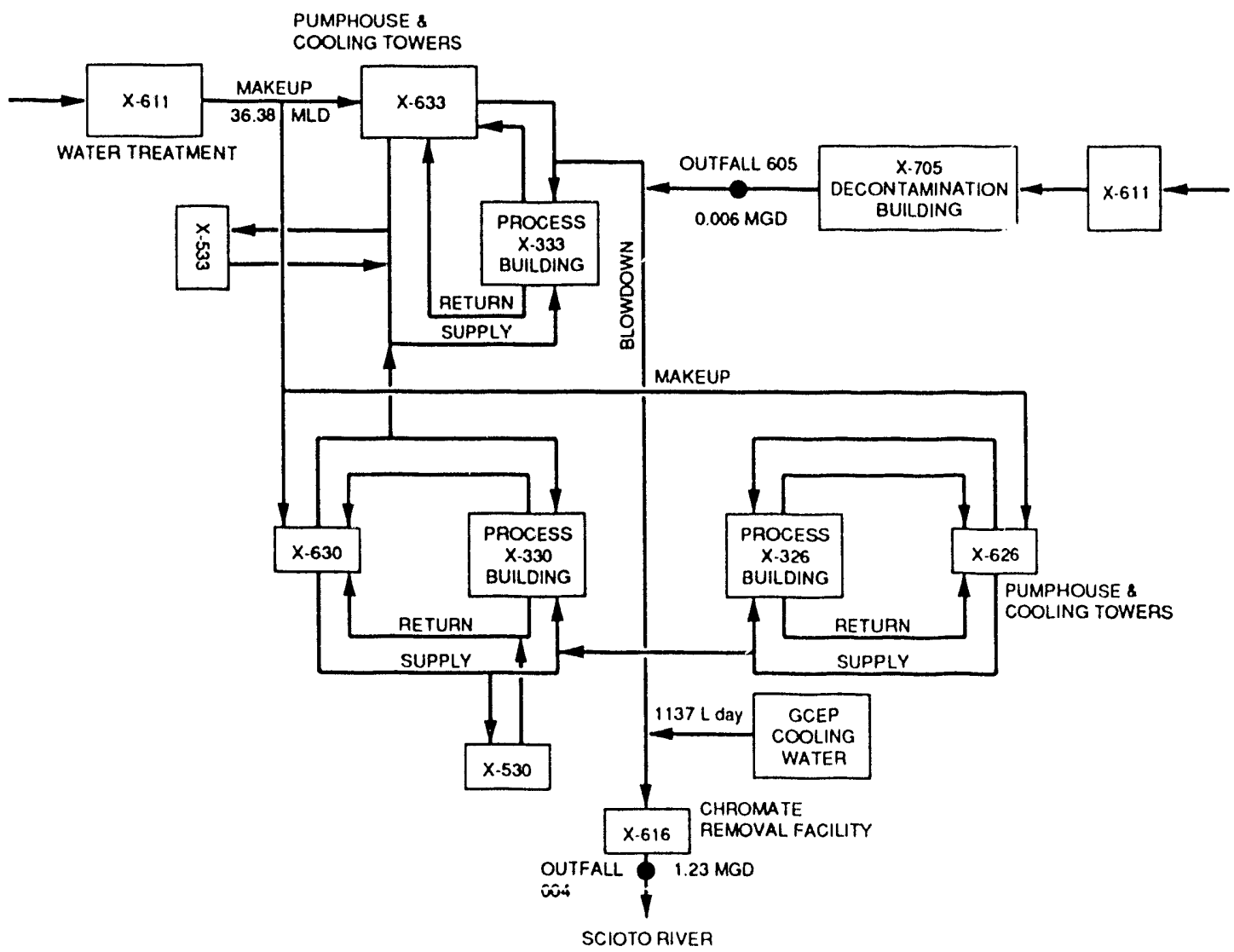

Fig. 3.8. Outfalls 004 and 605 flow diagram. 


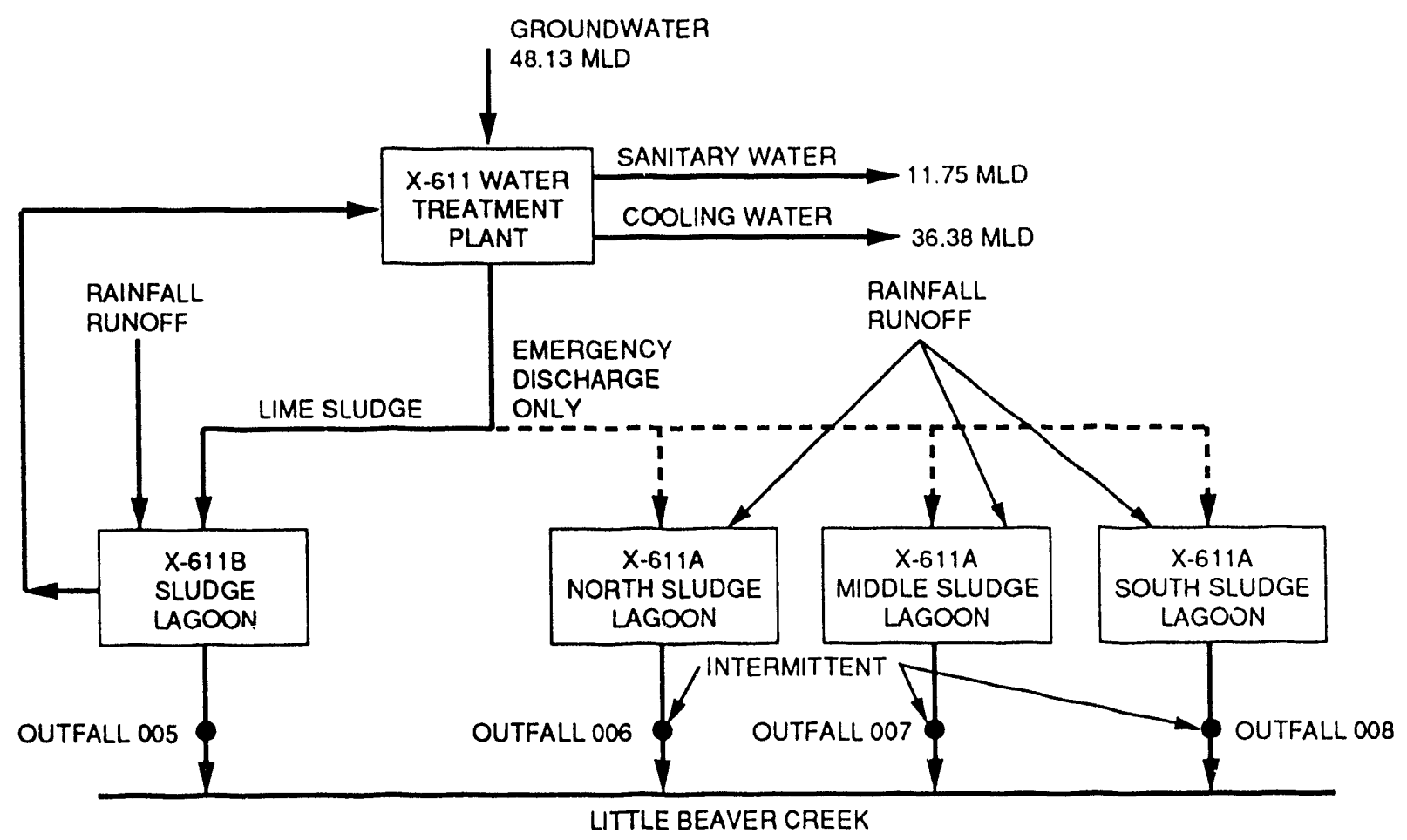

Fig. 3.9. Outfalls $005,006,007$, and 008 flow diagram.

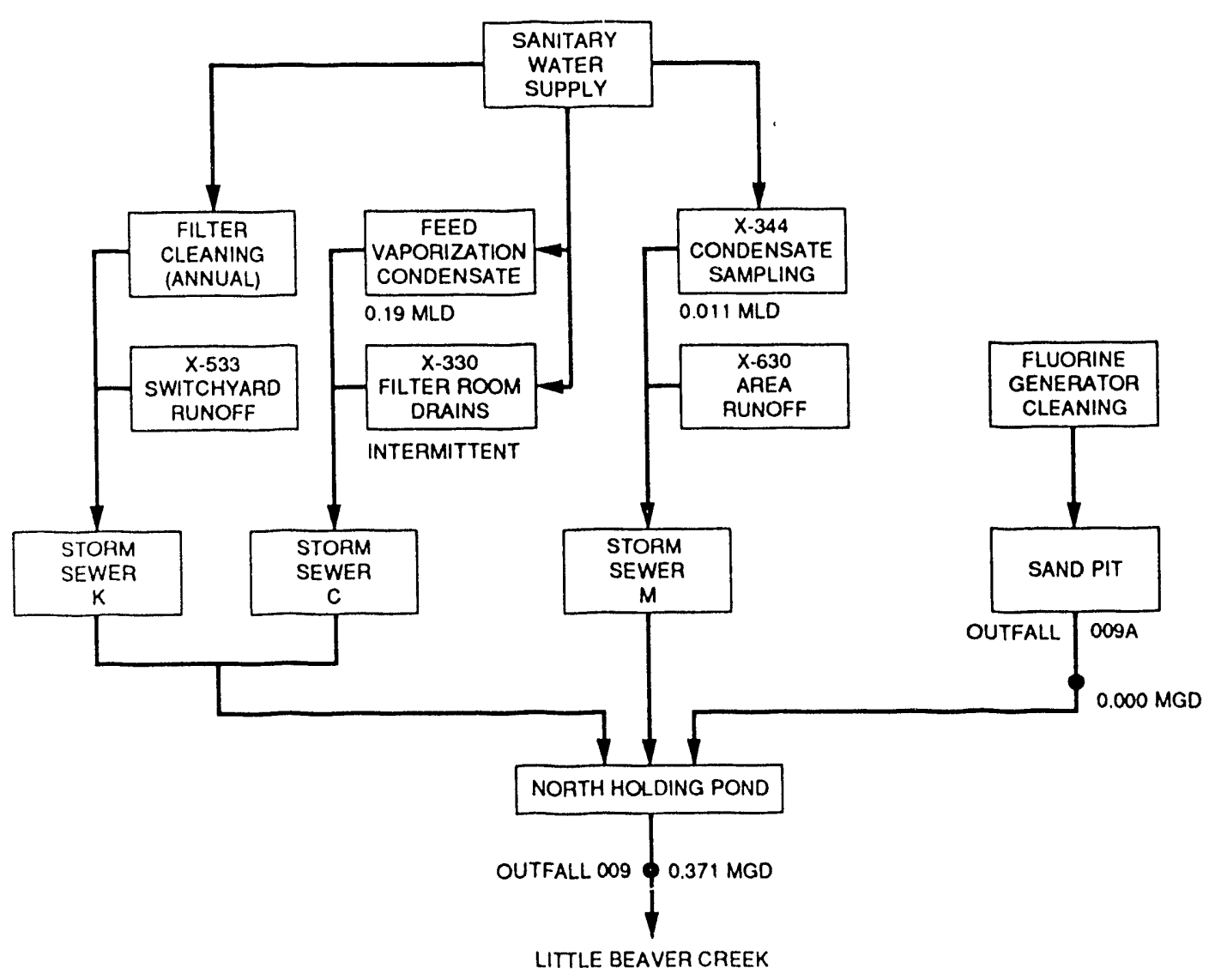

Fig. 3.10. Outfalls 009 and 009A flow diagram. 


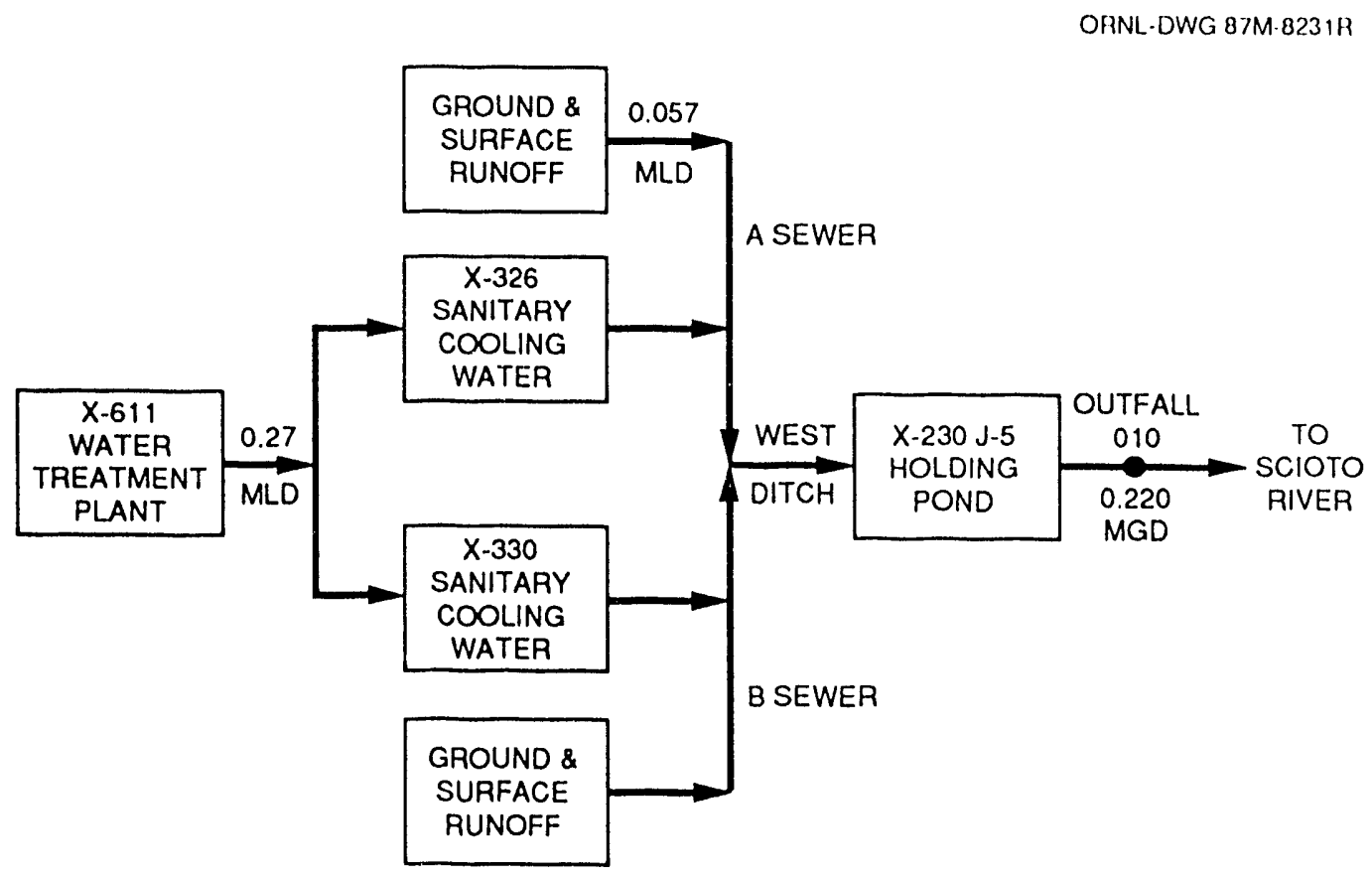

Fig. 3.11. Outfall 010 flow diagram.

ORNL-DWG 88M-7731R

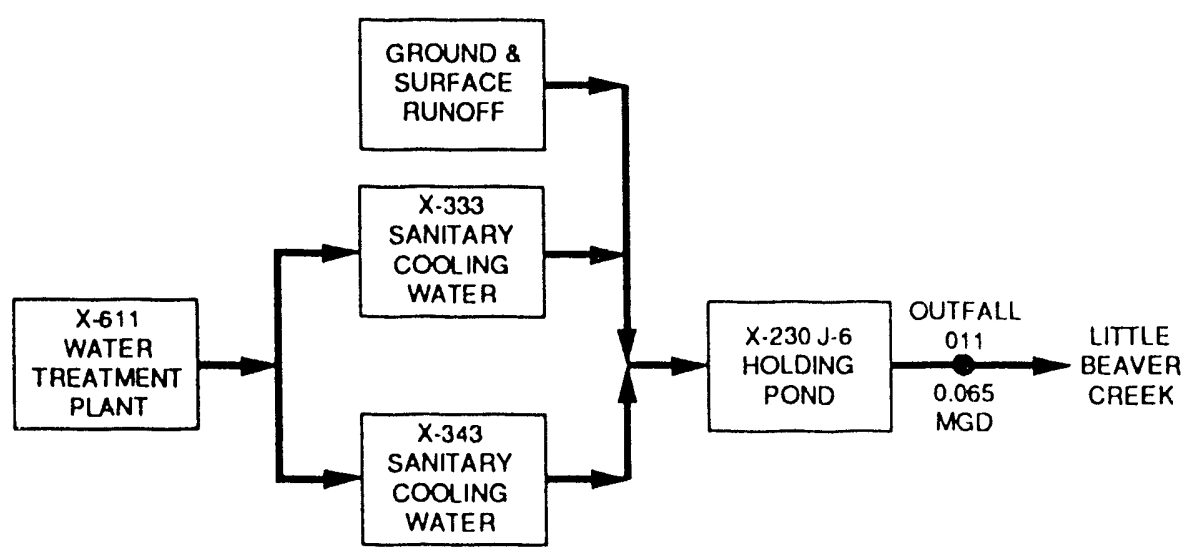

Fig. 3.12. Outfall 011 flow digram. 
As is shown in Fig. 3.14, a total of $0.358 \mathrm{Ci}$ of uranium was discharged in 1990. This was equivalent to $45 \mathrm{~kg}$ of uranium (Fig. 3.15). This is an increase over 1988 and 1989 but less than that discharged in 1987. The bulk of the uranium discharged was through outfall $001(76 \%)$ to Little Beaver Creek. The remaining uranium was discharged through outfall $004(4 \%)$, outfall 003 (sewage treatment plant) $(17 \%)$, outfall $002(1 \%)$, and outfall $009(1 \%)$. Only trace amounts were discharged through the remaining outfalls. The increase in uranium discharges can be attributed to accidental releases. Because the X-705 microfiltration process discharges to the plant's $\mathrm{RCW}$ blowdown line and is further treated at the X-616 chromate treatment facility (004), there is a measurable increase of uranium at the 004 effluent not seen in previous years (see Table 3.4). This increase in uranium is responsible for the $4 \%$ of the total plant uranium being discharged at outfall 004 .

On a mass basis the major portion of the uranium at PORTS is the isotope ${ }^{238} \mathrm{U}$, but most of the alpha radioactivity comes from the isotope ${ }^{234} \mathrm{U}$. Individual isotopic measurements are not made at NPDES outfalls. They can be calculated from the alpha radioactivity data and the cascade gradient.

As is shown in Fig. 3.16, a total of $1.35 \mathrm{Ci}$ of technetium was discharged in 1990. The increase for 1990 can be attributed to an increase in decontamination activity in the X-705 facility. It is, however, a considerable improvement when compared to previous years when $9.34 \mathrm{Ci}$ (1984), $8.45 \mathrm{Ci}(1985)$, and $2.48 \mathrm{Ci}$ (1986) of ${ }^{99} \mathrm{Tc}$ were released. The improvement since 1986 can be attributed to: enhanced technetium removal in the ion exchange section of the $\mathrm{X}-705$ raffinate treatment system, water conservation efforts in X-705; decontamination efforts; and, in part, operation of the new X-705 microfilter. In addition, the effluent from the ion exchange columns is redirected to the X-700 biodenitrification facility and the $X-6619$ sewage treatment p! unt, which may further reduce technetium levels. Technetium, a weak beta emitter, accounts for the bulk of the radioactivity release $(71 \%)$ from the facility. Of the total technetium released, $10 \%$ was discharged through outfall 001 to Little Beaver Creek; 6\%, through outfall 003 to the Scioto River; and $83 \%$, through outfall 004 also to the Scioto River. The remaining $1 \%$ was distributed among the remaining outfalls.
As is shown in Fig. 3.17, the total millicuries of uranium daughter products discharged to surface water in 1990 was $406.7 \mathrm{mCi}$. This was a considerable increase from previous years. Uranium daughter products are generated by the natural radioactive decay of uranium and therefore roughly follow uranium emissions. Because ${ }^{238} \mathrm{U}$ generates the bulk of the detectable uranium daughters, the proportion of uranium daughter products to total uranium will vary with the uranium assay. Uranium daughter products account for $19 \%$ of all curies discharged. Seventy percent of the daughter products discharged were through outfall 004; another $18 \%$, through outfall 001 ; and another $9 \%$ through outfall 003 . The remaining $3 \%$ was divided among the other NPDES outfalls.

Alpha and beta-gamma radioactivity and total uranium data presented in Tables 3.2 through 3.4 were derived from individual analyses data at each sampling location. NPDES outfall locations that were sampled in 1990 include 001, 601, 002, 003, 004, 605, 009, 010, and 011 for Gaseous Diffusion Plant (GDP) outfalls and 001 through 003 for GCEP outfalls. These locations are shown in Fig. 3.2.

Outfall 605 (see Fig. 3.2) currently has the most concentrated radioactive discharge from plant operations. This outfall replaced the X-701B holding pond (NPDES outfall 601) in November 1988. Treated wastewater from this new X-705 microfilter is discharged to the RCW blowdown line and is further treated at the X-616 chromate treatment facility (NPDES 004) and discharged to the Scioto River. However, effluent flow from this new facility averaged only $6000 \mathrm{gal} /$ day during 1990 . Also included in Tables 3.2 through 3.4 are radioactivity data at upstream and downstream locations in the surface waters (designated as RW locations) that receive discharges from these NPDES outfalls. These locations are shown in Fig. 3.3.

\subsubsection{NPDES Nonradiological Summary}

The locations of NPDES discharge outfalls are shown in Fig. 3.2. The 1986-1990 percentages of compliance at the east drainage ditch (NPDES 001) for total susperided solids (TSS), oil and grease (O\&G), total residual chlorine (TRCL), and $\mathrm{pH}$ are given in Figs. 3.18 through 3.21. Compliance for $\mathrm{O} \& \mathrm{G}$ and $\mathrm{pH}$ was $100 \%$; compliance for TSS and TRCL was $98 \%$ and $90 \%$ respectively. One TSS 
exceedance was the reason for the $98 \%$ compliance and was the result of heavy rainfall runoff. Five chlorine exceedances during 1990 account for the 90\% compliance. Exact reasons for these chlorine exceedances could not be readily determined. Heavy use of chlorinated sanitary drinking water and reduced retention times in the $\mathrm{X}-230 \mathrm{~J} 7$ pond for dissipation are suspected reasons. An engineering study is under way to reduce the use of chlorinated water or provide dechlorination facilities.

The 1986-1990 percentages of compliance at the $\mathrm{X}$-701B holding pond (NPDES $001 \mathrm{~A}$ ) for total zinc, total iron, and total chromium are given in Figs. 3.22 through 3.24. Effluent from the X-701B holding pond was sporadic in 1990 as all process discharges to the pond were halted in early November 1988 to comply with RCRA closure requirements. Discharges from the pond were the result of rainfall runoff and/or groundwater infiltration. During uays when an effluent flow was observed, compliance with all NPDES parameters was $100 \%$.

The 1986-1990 percentages of compliance at the south holding pond (NPDES 002) for TSS, O\&G, TRCL, and pH are given in Figs. 3.25 through 3.28. Compliance remains high for all parameters. The one exceedance for TSS resulting in the $98 \%$ compliance was caused by heavy rainfall runoff. The one $\mathrm{pH}$ exceedance resulting in the $98 \%$ compliance was caused by a malfunctioning caustic feed pump.

The 1986-1990 percentages of compliance at the $\mathrm{X}-621$ coal pile treatment plant (NPDES 002A) for TSS, total iron, total manganese, and $\mathrm{pH}$ are given in Figs. 3.29 through 3.32. Overall compliance improved substantially over 1989 . One $\mathrm{pH}$ exceedance resulting in $98 \%$ compliance was due to heavy rainfall and an overflow of the X-621 lagoon.

The 1986-1990 percentages of compliance at the X-6619 sewage treatment plant (NPDES 003) for biochemical oxygen demand, TSS, fecal coliform, $\mathrm{pH}$, and TRCL are given in Figs. 3.33 through 3.37. Compliance continues to remain high for all parameters. Two exceedances for fecal coliform caused by operator underchlorination resulted in the $97 \%$ compliance. One exceedance for chlorine resulted in the $98 \%$ compliance. Operator error of overchlorination is suspected.

The 1986-1990 percentages of compliance at the biodenitrification facility (NPDES 003B) for nitrate, total copper, total zinc, total iron, nickel, and $\mathrm{pH}$ are given in Figs. 3.38 through 3.43. Compliance is high for all parameters.

Although it cannot be proved after the fact, investigators concluded that an unrepresentative sample probably resulted in two exceedances each for copper, zinc, iron and nickel, or $98 \%$ compliance.

The 1986-1990 percentages of compliance at the X-616 chromate treatment facility (NPDES 004) for total dissolved solids, TSS, total zinc, hexavalent chromium, total chromium, total iron, total copper, TRCL, trichloroethylene (TCE), and $\mathrm{pH}$ are given in Figs. 3.44 through 3.53. Compliance remains high for all parameters except total chromium. Two exceedances for total suspended solids and total zinc resulted in $97 \%$ compliance. Four exceedances for total chromium resulted in a $92 \%$ compliance. Investigations concluded that these were the result of either an unrepresentative sample or discrepancies between field and laboratory operating data. These problems have been corrected. One chlorine exceedance, for which no reason could be determined, resulted in $98 \%$ compliance.

Percentage of compliance graphs are not presented for NPDES outfalls 005, 006, 007, 008, 009A, and GCEP 003. Effluent flows were very infrequent at these outfalls during 1990, resulting in skewed compliance rates.

The 1986-1990 percentages of compliance at the north holding pond (NPDES 009) for TSS, O\&G, TRCL, and $\mathrm{pH}$ are given in Figs. 3.54 through 3.57. Three monthly average exceedances resulted in $95 \%$ TSS compliance at this outfall. All exceedances were the result of seasonal heavy rainfall runoff. Compliance for all other parameters was $100 \%$.

The 1986-1990 percentages of compliance at the west drainage ditch (NPDES 010) and northeast drainage ditch (NPDES 011) for O\&G and $\mathrm{pH}$ are given in Figs. 3.58 through 3.61. Compliance remains high $(100 \%)$ for all parameters measured.

The 1986-1990 percentages of compliance at the two GCEP ponds NPDES G001 and NPDES G002 for TSS, O\&G, and pH are given in Figs. 3.62 through 3.67. Compliance is high $(100 \%)$ for all parameters except TSS at GCEP 001 . One daily maximum and one monthly average exceedance due to extremely heavy rainfall runoff resulted in the $97 \%$ compliance.

In addition to specific parameter percent compliances shown, numerous unpermitted discharges occurred at the PORTS facility, impacting 
several NPDES outfalls and receiving streams. Twenty unpermitted discharges occurred during CY 1990. They were the result of RCW line breaks, chlorinated sanitary drinking water line breaks, minor discharges of process wastewater due to drain plugging, leaks, and tank overflows. Investigations and corrective actions to prevent recurrences of these discharges are in progress.

\subsection{POLlUtion ABATEMENT PROJECTS AND ACTIVITIES}

In 1987 construction began on a waste treatment facility to treat all wastewaters currently flowing from the X-705 decontamination building to the $\mathrm{X}-701 \mathrm{~B}$ holding pond. This project was completed in early November 1988 and placed in operation in mid-November to meet the November 8,1988 , RCRA closure requirement for the $\mathrm{X}-701 \mathrm{~B}$ holding pond. Operations and optimization of this facility continued through CY 1990 . The new X-705 waste treatment facility installed in the $X-705$ decontamination building uses microfiltration and pressure filtration technology to treat all process waters produced in the $\mathrm{X}-705$ building. Discharge is to the RCW blowdown line, which is further treated at the X-616 chromate treatment facility before being discharged to the Scioto River. Building drainage, noncontact cooling water, and evaporator condensate that are uncontaminated from X-705 processes are discharged directly to the east drainage ditch, NPDES outfall 001, and finally to Little Beaver Creek in accordance with the project OEPA Permit to Install (PTI) agreement.

Optimization of the full-scale biodenitrification facility located in the X-700 building was completed. Startup began in May 1987; however, the facility experienced numerous startup problems and frequently exceeded effluent limitations.

Optimization efforts focused on improving nitrate reduction efficiency and improving metals removal. Detailed reports covering the optimization efforts and achievements were completed in December 1988 and in March 1990 for CYs 1988 and 1989 respectively. These reports were forwarded to OEPA per draft NPDES permit requirements (PORTS December 1988; PORTS March 1990).

A study to replace the chromate-based corrosion inhibitor (Betz GDP, a proprietary coolant system coniusion inhibitor for gaseous diffusion plants) used in the RCW system continued through CY 1990. The hexavalent chromium concentration in the $\mathrm{RCW}$, a result of the inhibitor, is considered toxic to aquatic life, and RCW spills lost off-site are considered NPDES violations. Phosphate-based corrosion inhibitors exist that could possibly replace the present formulation. The environmental advantages of replacing the shromate-based inhibitor include the possible elimination of the need for X-616 operation and associated NPDES violations resulting from RCW spills, and a reduction in the severity of NPDES violations associated with RCW spills. The study, which is expected to span several years, will investigate phosphate-based as well as other less toxic corrosion inhibitor systems. The X-626 and $\mathrm{X}-630$ cooling water systems were converted to phosphate in June 1989 and November, 1990, respectively. The remaining system (X-633) is scheduled to begin conversion by June 1991 .

In August 1988 a program to control algae growth and consequent high pH exceedances in GCEP ponds was initiated. Stringent NPDES $\mathrm{pH}$ limits of $6.5 \leq \mathrm{pH} \leq 8.5$ exist at the two GCEP ponds (outfalls G001 and G002). Algae and its associated diurnal $\mathrm{pH}$ variations frequently caused the $\mathrm{pH}$ to exceed the upper limit. In early August 1988, the ponds were intentionally drained and refilled to upset the algae growth. From August 1 to December 31, 1988 , only $4 \mathrm{pH}$ exceedances occurred, compared with 67 exceedances for the same period in 1987. Throughout all of CY 1989, only $11 \mathrm{pH}$ exceedances occurred at these two outfalls. In CY 1990 , continuation of this practice resulted in no exceedances at these outfalls. This practice will continue until the stringent $\mathrm{pH}$ limitations are relaxed to a more reasonable $6.5 \leq \mathrm{pH} \leq 9.0$ when the new NPDES permit is signed.

A new project was initiated in 1988 to dredge the south holding pond (NPDES 002) and to upgrade NPDES monitoring facilities. Settled silt and coal fines are frequently resuspended during heavy rainfall and cause suspended solids and metai concentrations to increase in the pond effluents. Dredging was one means approved by OEPA to meet new stringent effluent limitations in the new NPDES permit. Due to a slip in funding, construction is not expected to begin until mid-summer 1991. The sludge will be sampled, characterized, and disposed in the X-735 sanitary landfill. 
Projects related to improving NPDES compliances at PORTS and proactively meeting proposed more stringent water quality limits at several outfalls include (1) construction of additional treatment facilities at the south holding pond (NPDES $002)$ and (2) the X-621 coal pile treatment facility (NPDES 602). At the south holding pond, additional pH adjustment facilities (i.e., the capability to adjust $\mathrm{pH}$ downward) will be added. Sand filters will also be installed to improve TSS and metals removal. Flow equalization and containment capabilities will also be installed. Construction is planned for CY 1991. At the $\mathrm{X}-621$ facility, planned improvements include the installation of sand filters, improved $\mathrm{pH}$ adjustment, a new lagoon lift station, an effluent tie to the RCW line as makeup water, improvements to the caustic tank dike, and instrumentation upgrading.

Construction is planned for CY 1991.

During the past few years, a significant number of TSS violations have occurred at NPDES outfalls handling surface runoff. The majority of these violations were attributable to extensive construction activities, especially at the 120 -ha (300-acre) GCEP site. Although most GCEP areas have been reseeded, a routine semiannual audit program has been developed to monitor site areas for erosion control. This program identifies all site areas with disturbed earth (e.g., construction areas or poorly vegetated areas) and ensures that necessary corrective actions are being taken to mitigate soil erosion areas.

Negotiation of the plant's new NPDES permit continued through 1990. A draft permit was issued in June 1988. Formal comments from Energy Systems, EPA, and other concerned parties have been received. Because of other priorities, OEPA has delayed further action on the permit. Further negotiations were held in March 1989 and throughout CY 1990. Issuance of a new permit is expected by mid-1991.

In 1989 an NPDES Task Team was formed, and an NPDES program manager was appointed. The program's objective is $100 \%$ compliance with the NPDES permit at PORTS and elimination of exceedances. The NPDES Task Team does trend analyses, identifies problem areas, establishes priorities, defines appropriate action, implements projects as necessary, tracks progress, and verifies successful completion of all projects. This program continued through CY 1990.

\subsection{FINDINGS AND CONCLUSIONS}

Radiological analyses are performed at NPDES sampling locations and RW locations that can better contribute to assessment of the impact of plant discharges on the receiving stream through upstream and downstream measurements. Analyses of Tables 3.2 through 3.4 and Figs. 3.14 through 3.17 show that the effects of discharges on the receiving stream have been minimal and are comparable to past annual discharges. Discharges to Little Beaver Creek appear to have only slight noticeable impact on radioactivity levels downstream, primarily because there are no upstream flows during much of the summer (i.e., plant discharges contribute $100 \%$ of the stream flow during dry summer months). Plant discharges appear to have no noticeable effect on radioactivity levels in Big Run Creek or the Scioto River. NPDES compliance by outfall and parameter is graphically presented in Figs. 3.18 through 3.67. Compliance by parameter varied from a low of $90 \%$ to a high of $100 \%$. Overall plant-wide NPDES compliance was $98 \%$ for CY 1990.

A number of pollution abatement projects and activities were initiated or completed in 1990 . They include (1) continued optimization of the X-700 biodenitrification facility and the X-705 waste treatment facility, (2) conversion of RCW chromate to phosphate, (3) continued successful algae control at GCEP ponds, (4) projects to modify and improve the south holding pond and the X-621 coal pile treatment facility, (5) continuation of the plant's erosion control program, (6) continuation of NPDES permit negotiations, and (7) continuation of the NPDES Task Team (see Subsect. 3.3). 


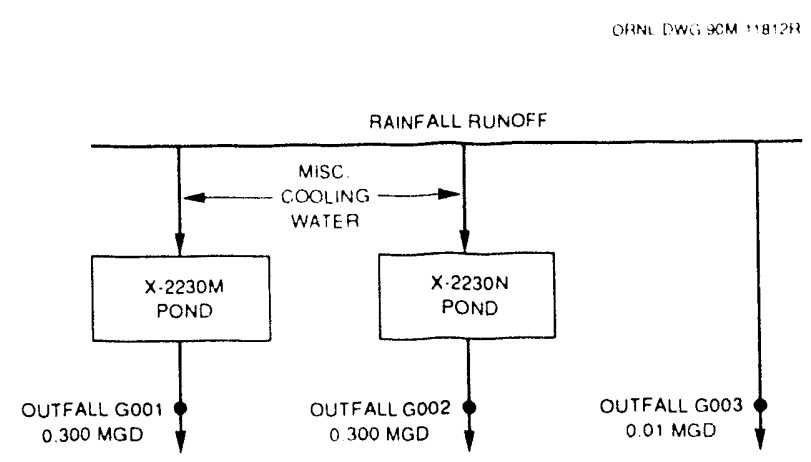

Fig. 3.13. Flow diagram for outfalls $\mathrm{G001}$ and $\mathrm{G002}$ and for the drainage sector originally designated as outfall G003.

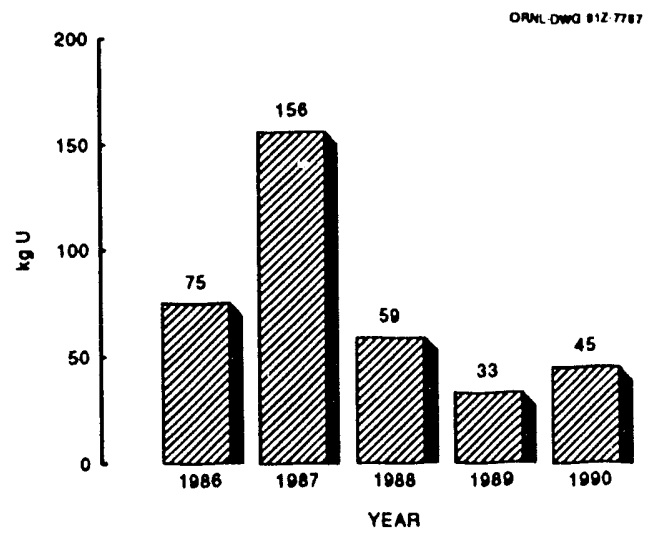

Fig. 3.15. Total kilograms of uranium discharged to surface water.

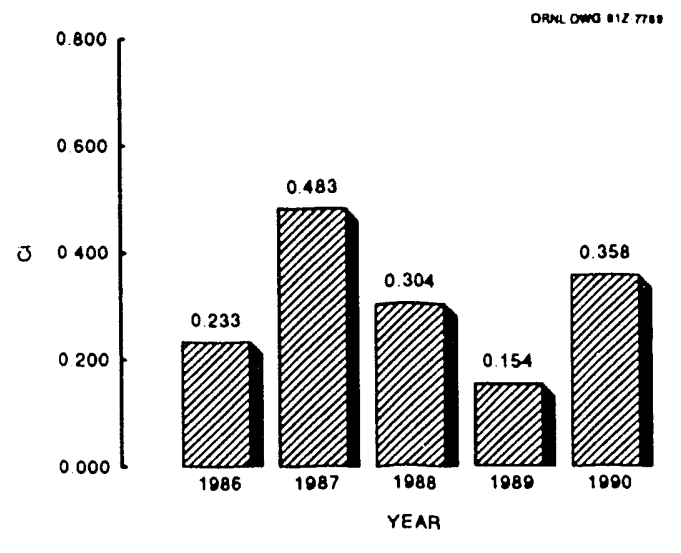

Fig 3.14. Total curies of uranium discharged to surface water.

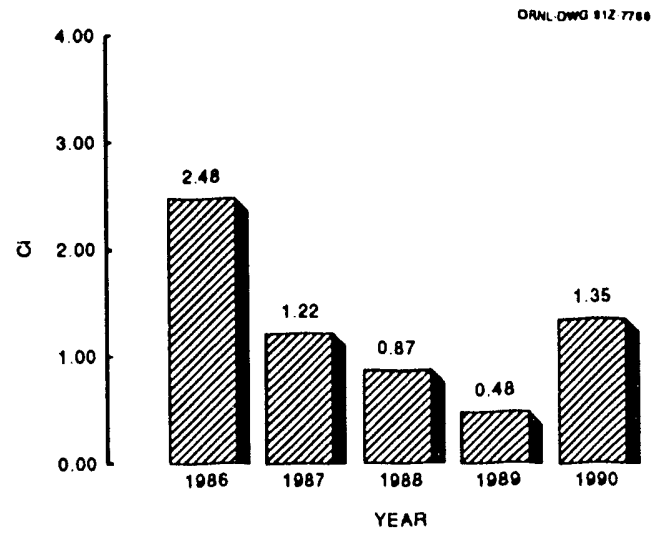

Fig. 3.16 Total discharges of ${ }^{99} \mathrm{Tc}$ to surface water. 


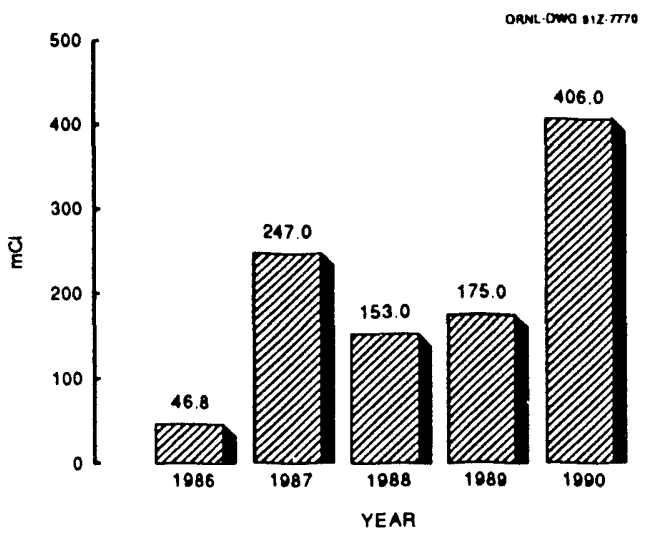

Fig. 3.17. Total discharges of uranium daughter products to surface water.

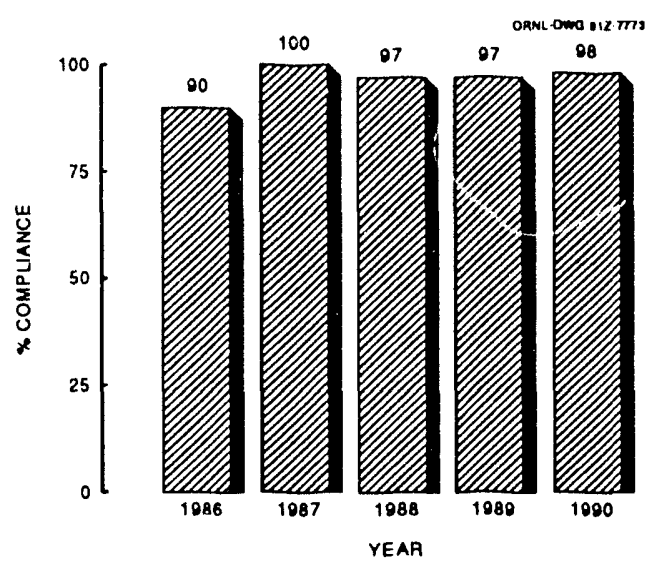

Fig. 3.18. NPDES compliance for total suspended solids at the east drainage ditch (001).

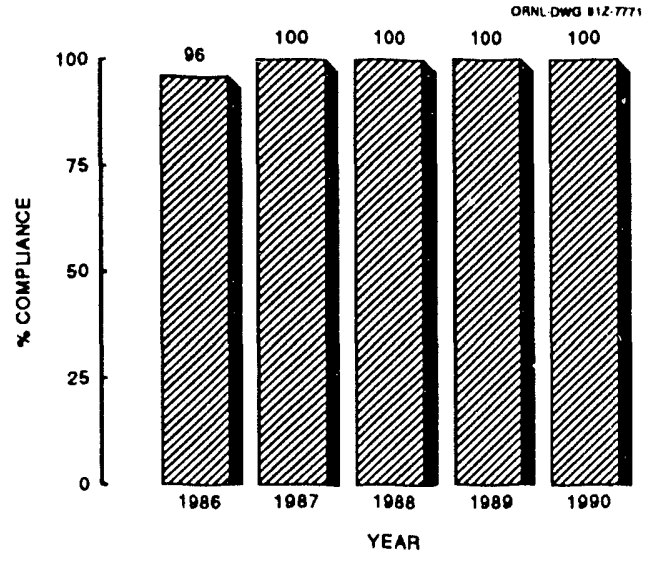

Fig. 3.19. NPDES compliance for oll and grease at the east drainage ditch (001).

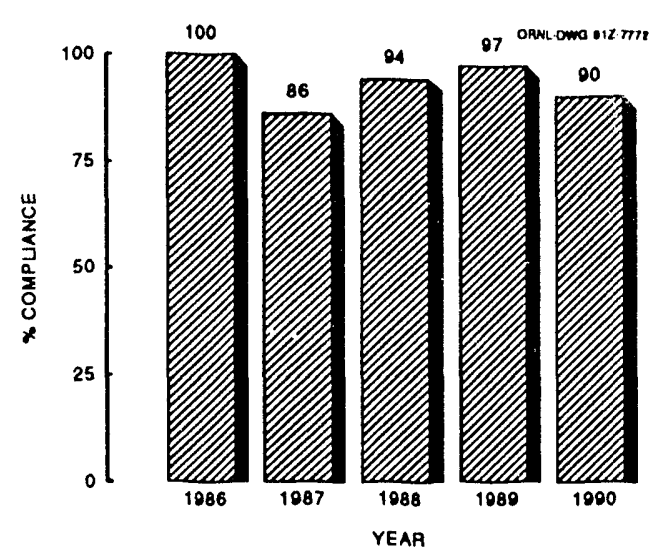

Fig. 3.20. NPDES compliance for total residual chlorine at the east drainage ditch (001). 


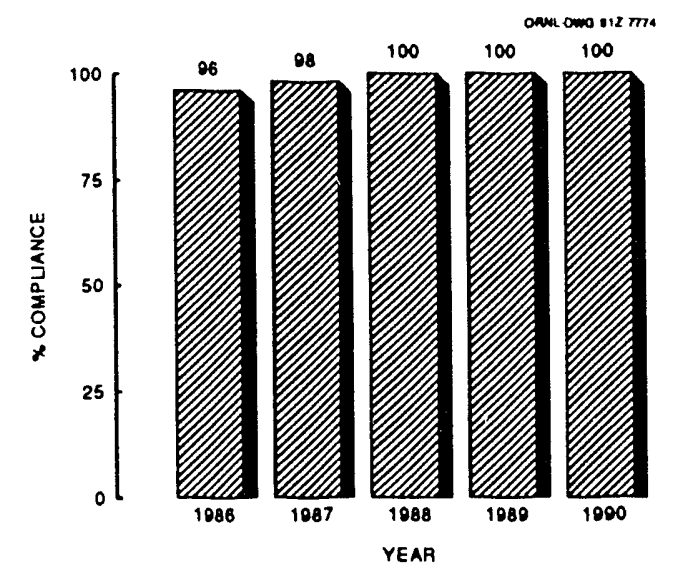

Fig. 3.21. NPDES compliance for $\mathrm{pH}$ at the east drainage ditch (001).

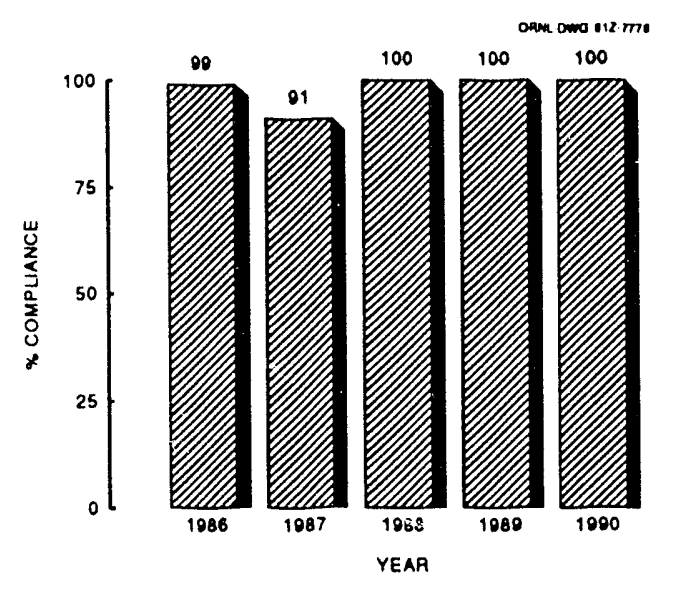

Fig. 3.22. NPDES compliance for total zinc at the $\mathrm{X}-701 \mathrm{~B}$ holding pond (001A).

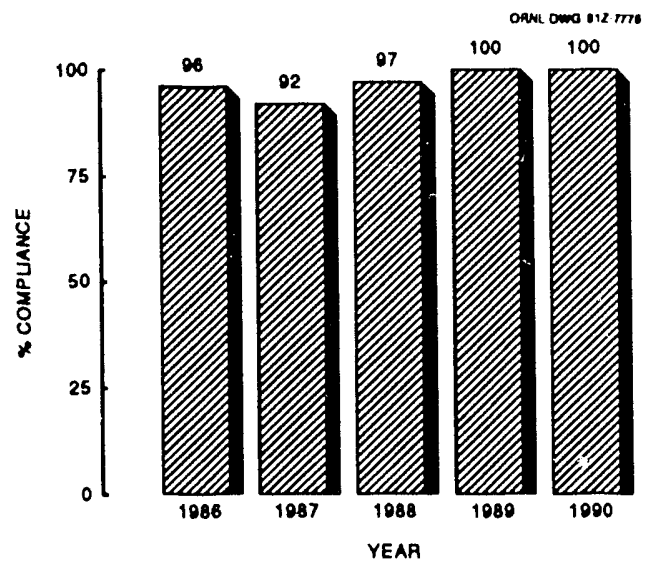

Fig. 3.23. NPDES compllance for total iron at the $\mathrm{X}-701 \mathrm{~B}$ holding pond $(001 \mathrm{~A})$.

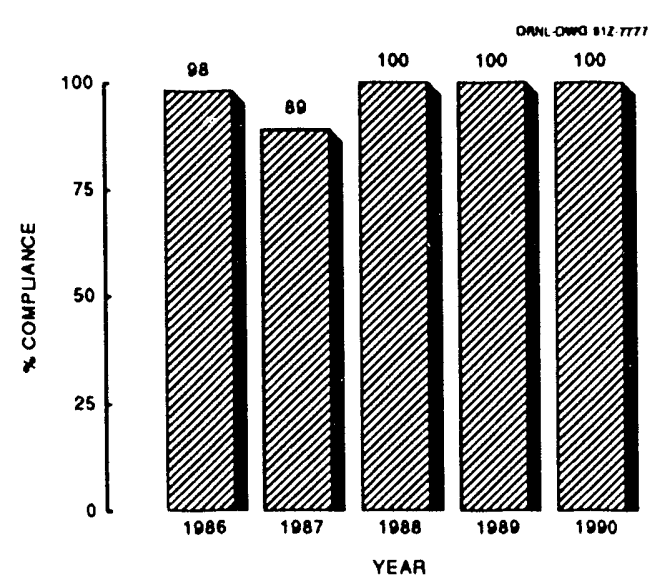

Fig. 3.24. NPDES compllance for total chromium at the X-701B holding pound (001A). 


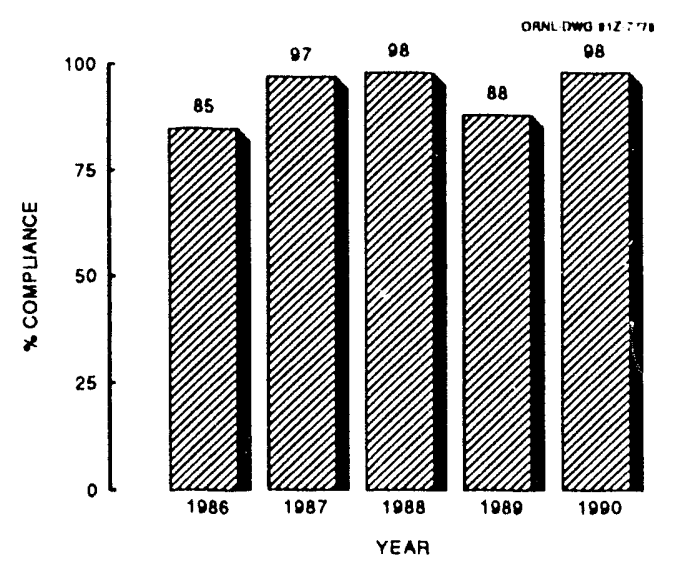

Fig. 3.25. NPDES compliance for total suspended solids at the south holding pond (002).

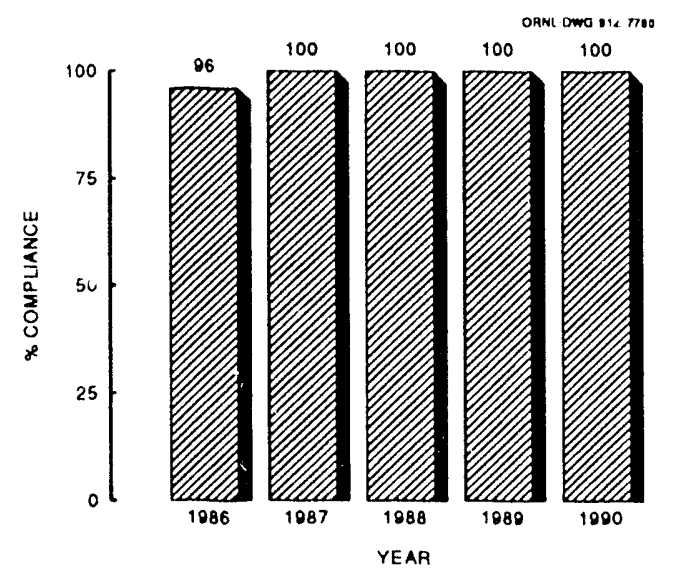

Fig. 3.26. NPDES compliance for oil and grease at the south holding pond (002).

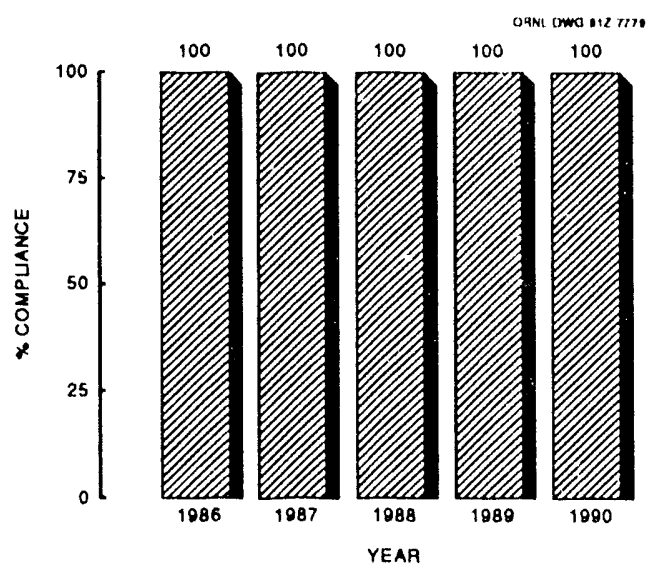

Fig. 3.27. NPDES compliance for total residual chlorine at the south holding pond (002).

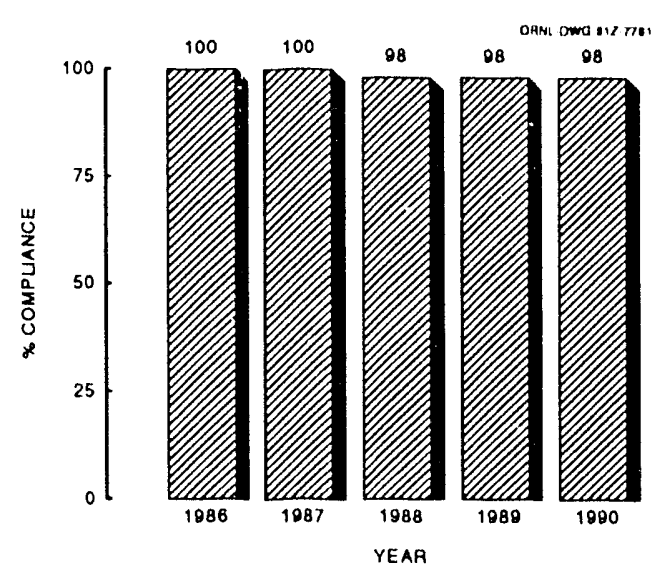

Fig. 3.28. NPDES compliance for $\mathrm{pH}$ at the south holding pond (002). 


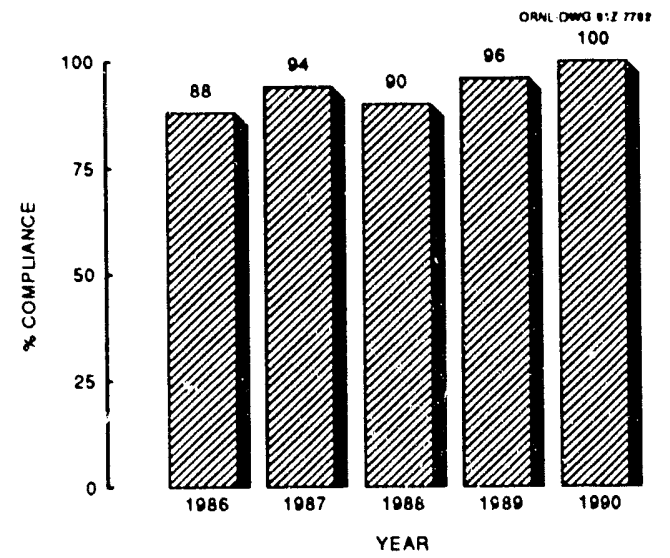

Fig. 3.29. NPDES compliance for total suspended solids at if : X-621 coal pile treatment plant (002 1 ).

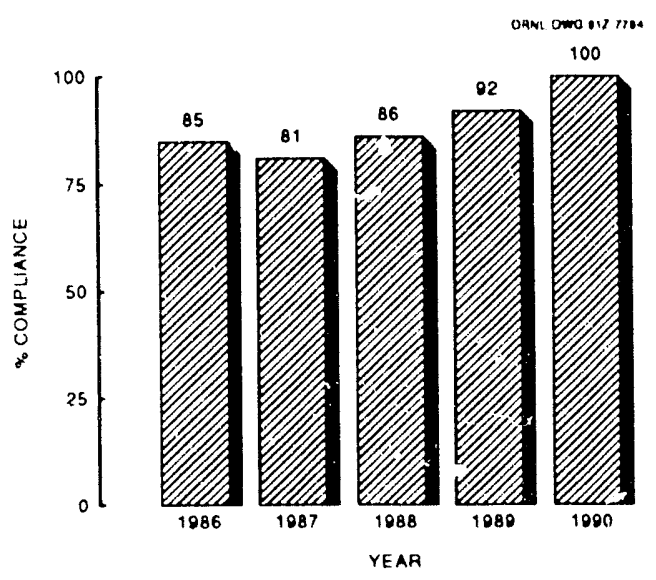

Fig. 3.30. NPDES compllance for total iron at the $X-621$ coal pile treatment plant $(002 A)$.

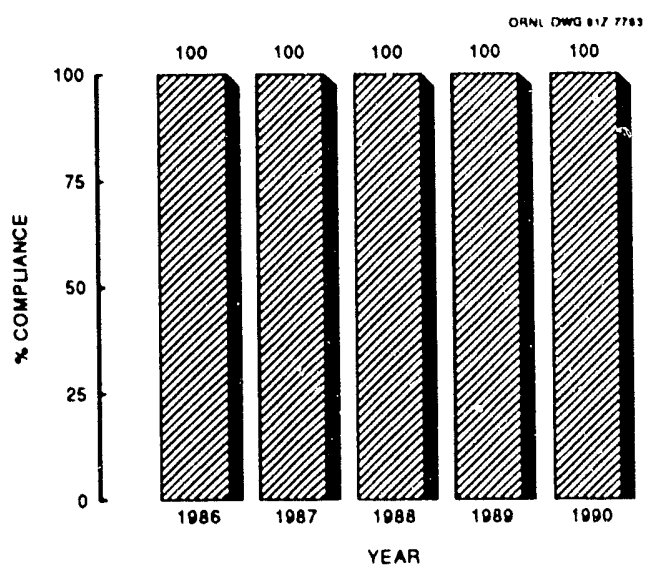

Fig. 3.31. NPDES compliance for total manganese at the $X-621$ coal pile treatment plant $(002 A)$.

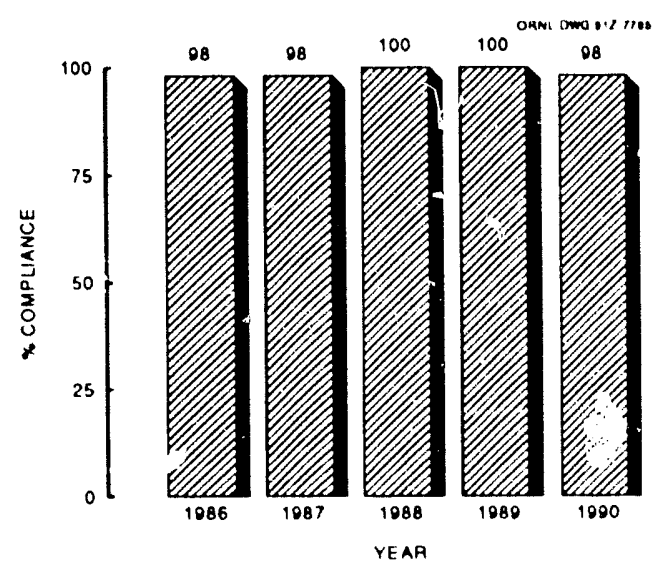

Fig. 3.32. NPDES compliance for $p H$ at the $X-621$ coal pile treatment plant $(102 \hat{A})$. 


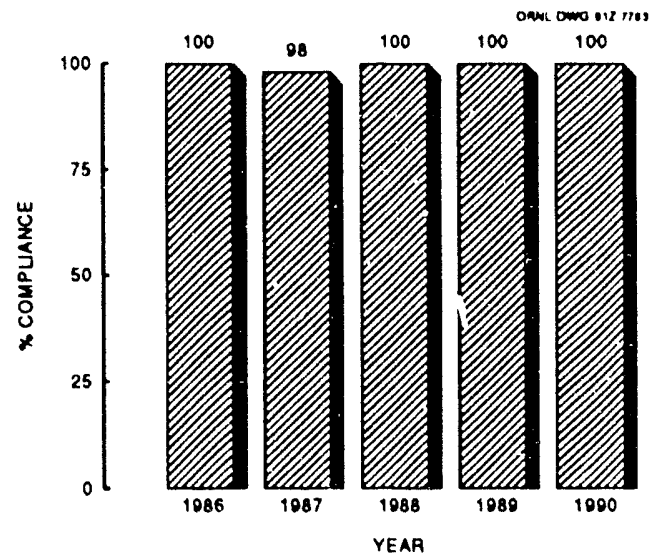

Fig. 3.33. NPDES compliance for biochemical oxygen demand at the X-6619 sewage treatment plant (003).

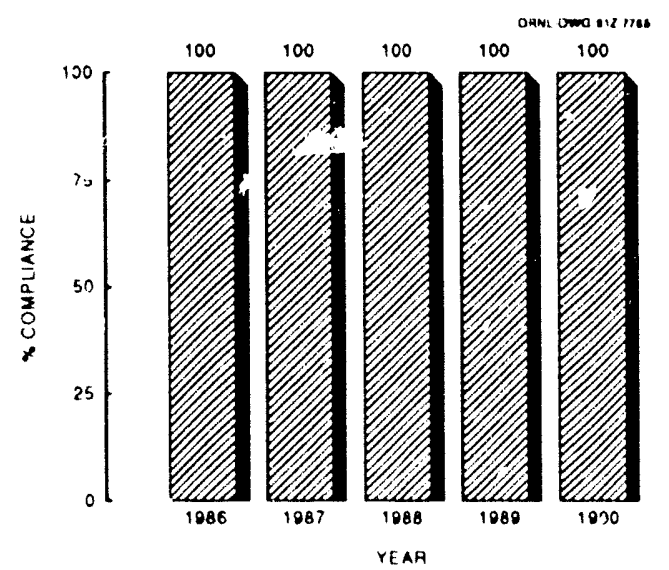

Fig. 3.34. NPDFS compliance for total suspended solids at the X-6619 sewage treatment plani (003).

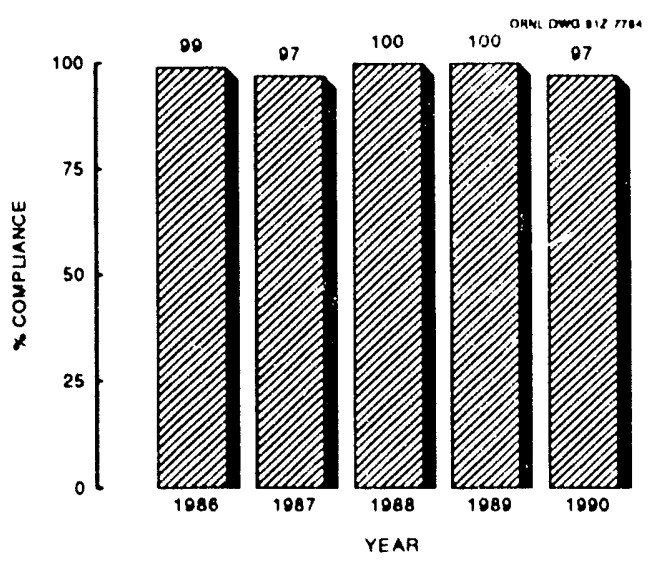

Fig. 3.35. NPDES compliance for fecal coliform at the X-6619 sewage treatment plant (003).

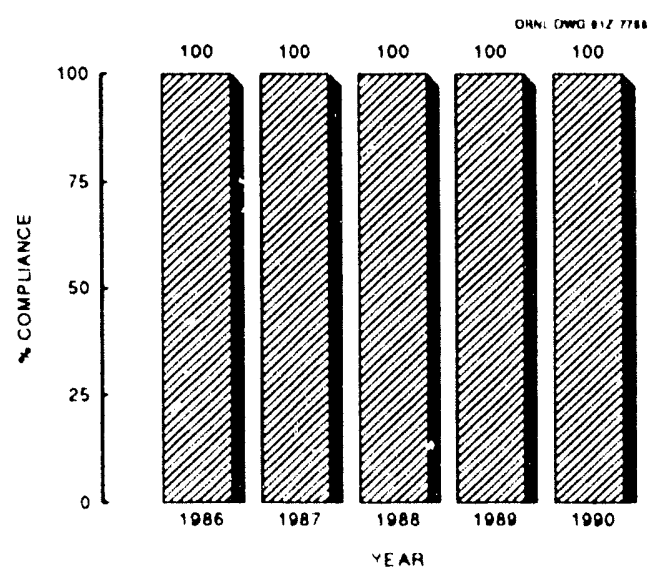

Fig. 3.36. NPDES compllance for $\mathrm{pH}$ at the $\mathrm{X}-6619$ sewage treatment plant (003). 


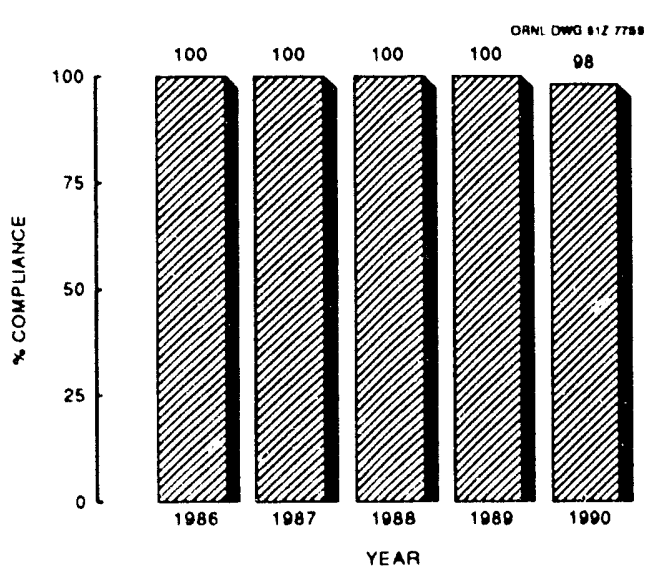

Fig. 3.37. NPDES compllance for total residual chlorine at the X-6619 sewage treatment plant (003).

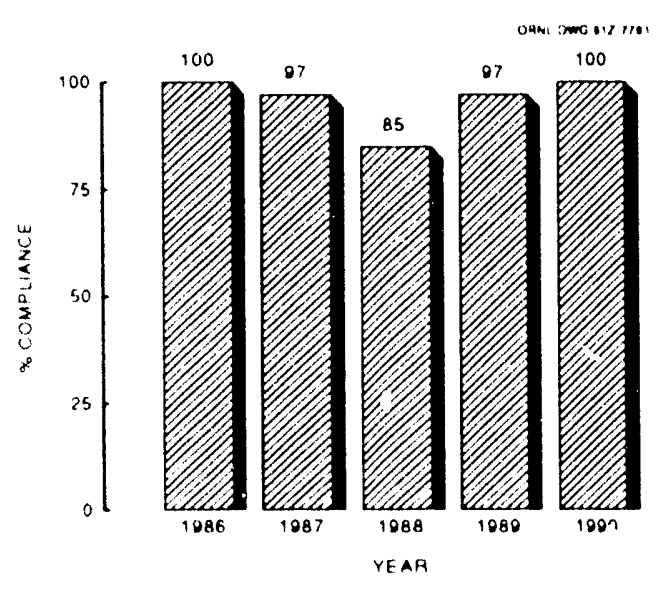

Fig. 3.38. NPDES compliance for nitrate at the biodenitrification facllity (003B).

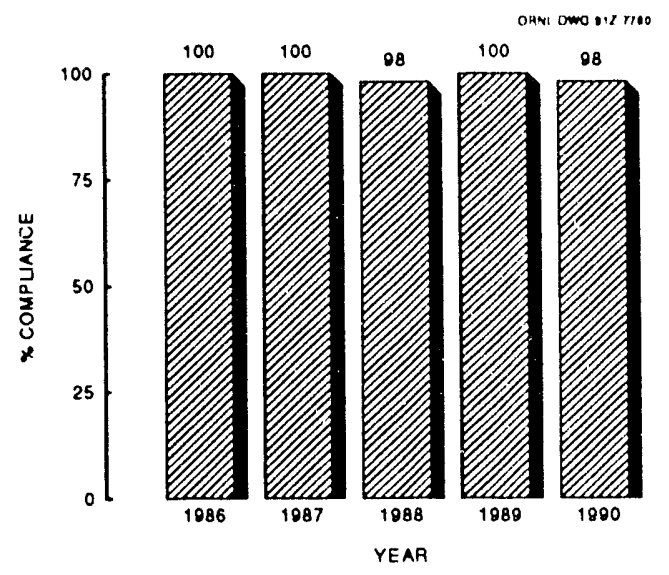

Fig. 3.39. NPDES compliance for total copper at the biodenitrification facility (003B).

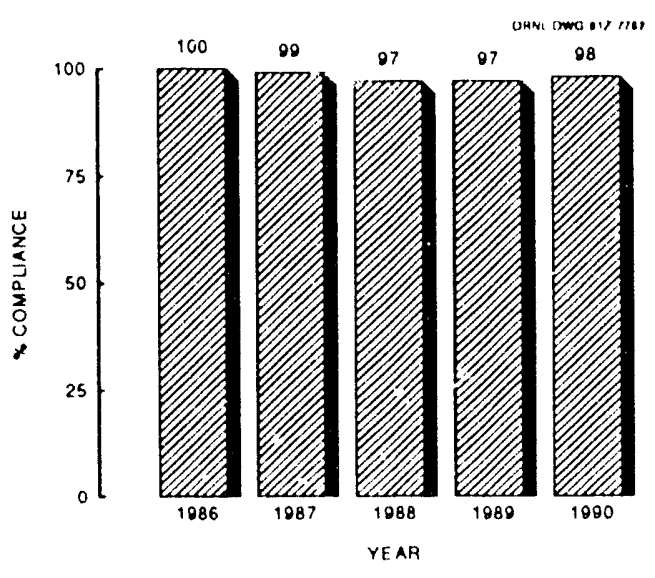

Fig. 3.40. NPDES compliance for total zinc at the biodenitrification facility (003B). 


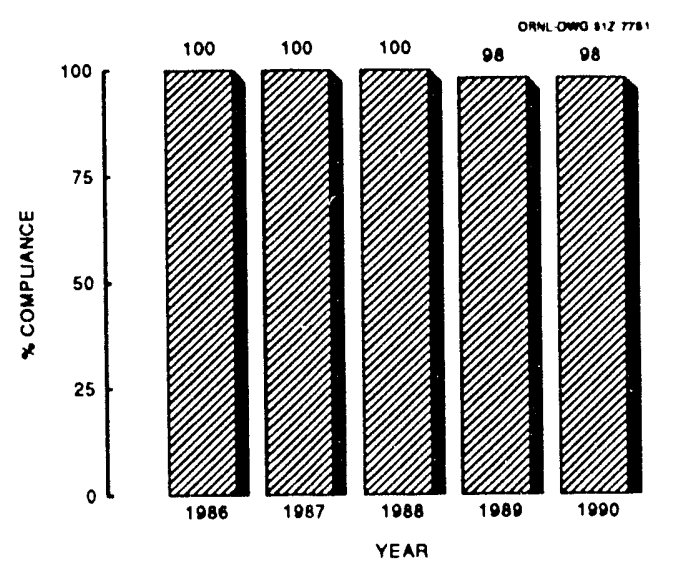

Fig. 3.41. NPDES compliance for total iron at the biodenitrification facility (003B).

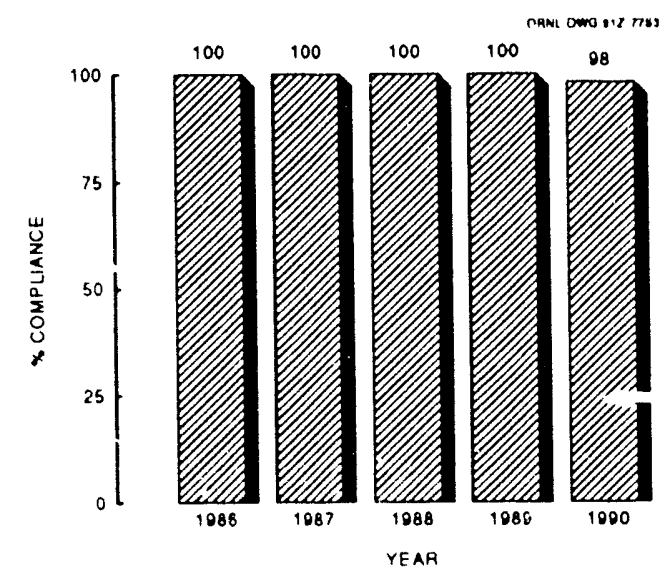

Fig. 3.42. NPDES compllance for nickel at the biodenitrification facility (003B).

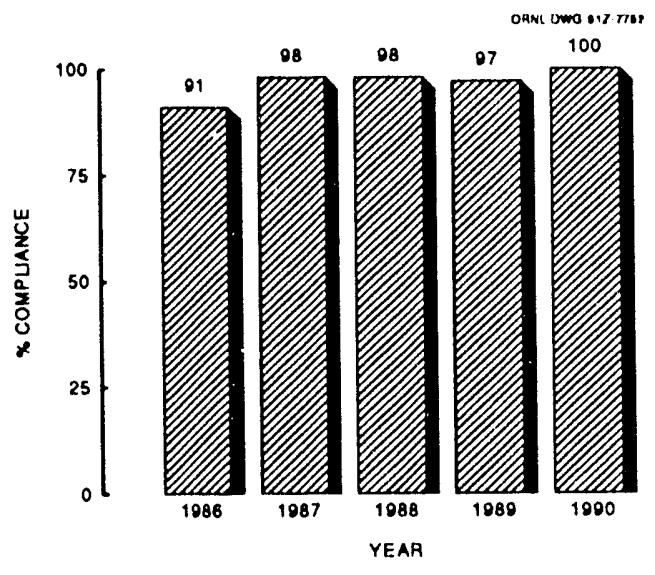

Fig. 3.43. NPDES compliance for $\mathrm{pH}$ at the biodenitrification facility (003B).

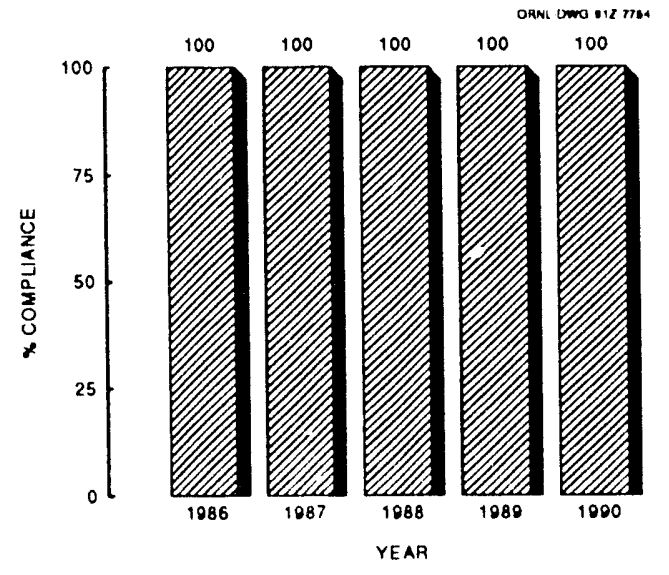

Fig. 3.44. NPDES compliance for total dissolved solids at the $\mathrm{X}-616$ chromate treatment facility (004). 


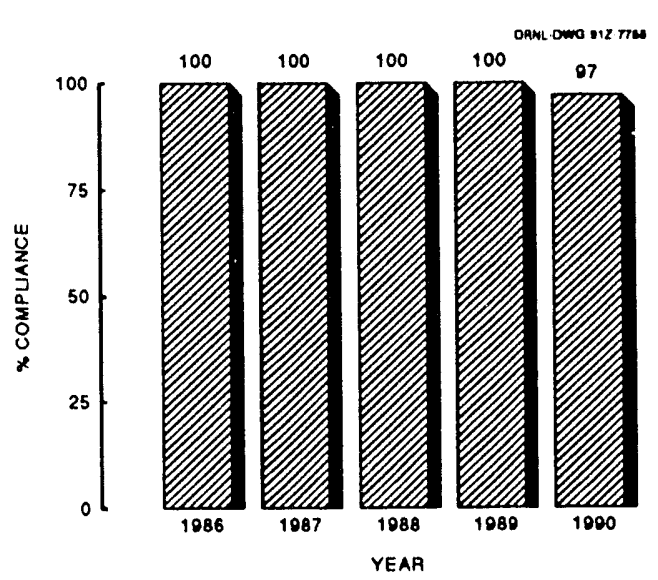

Fig. 3.45. NPDES compllance for total suspended solids at the X-616 chromate treatment facility (004).

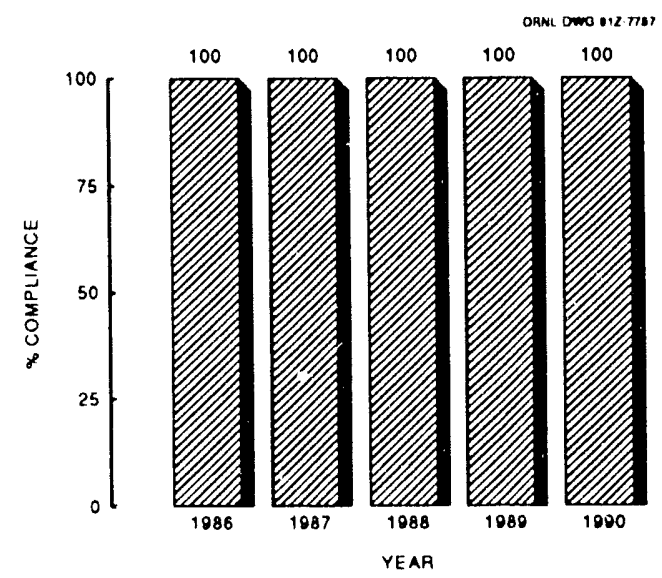

Fig. 3.46. NPDES compliance for total zinc at the $X-616$ chromate treatment facility (004).

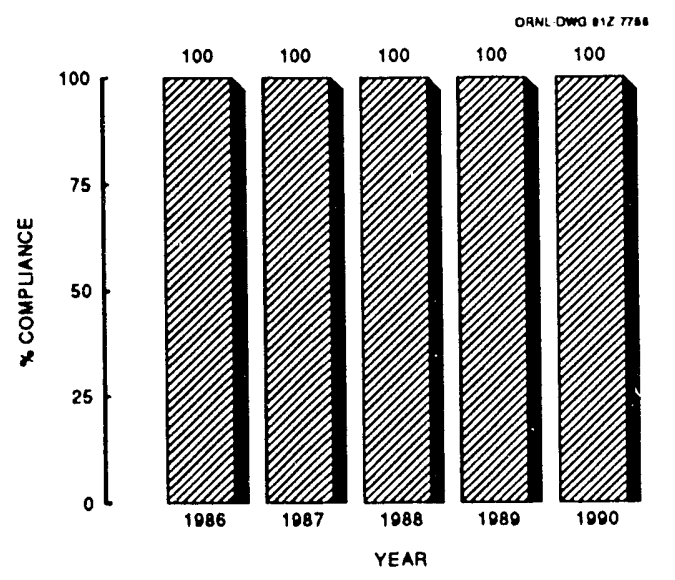

Fig. 3.47. NPDES compliance for hexavalent chromium at the X-616 chromate treatment facility (004).

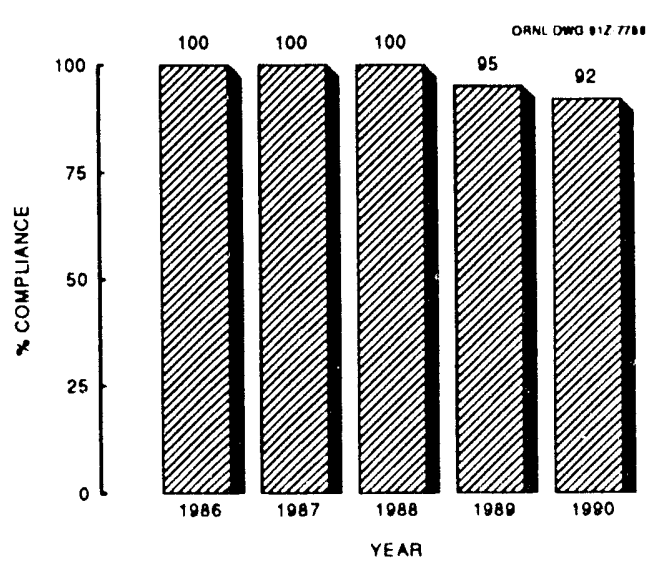

Fig. 3.48. NPDES compliance for total chromium at the X-616 chromate treatment facility (004). 


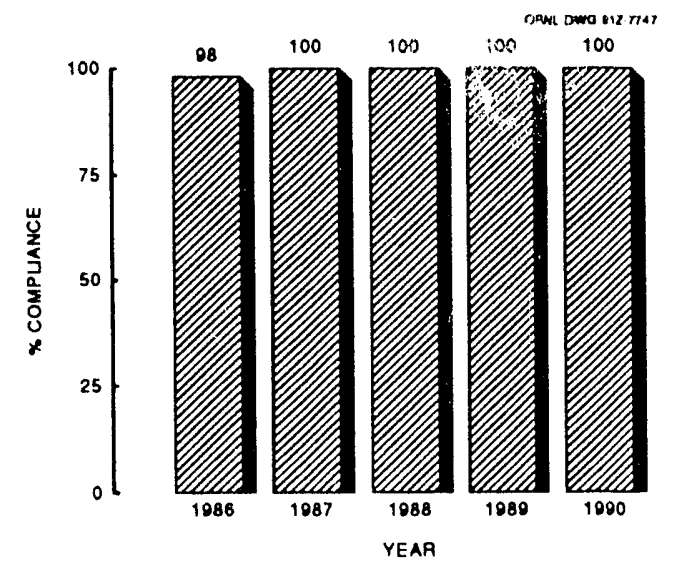

Fig. 3.49. NPDES compliance for total iron at the X-616 chromate treatment facility (004).

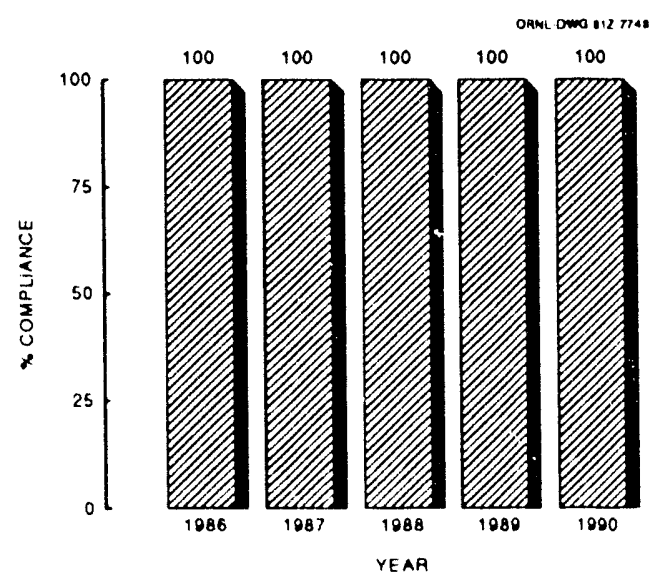

Fig. 3.50. NPDES compliance for total copper at the $X-616$ chromate treatment facility $(004)$.

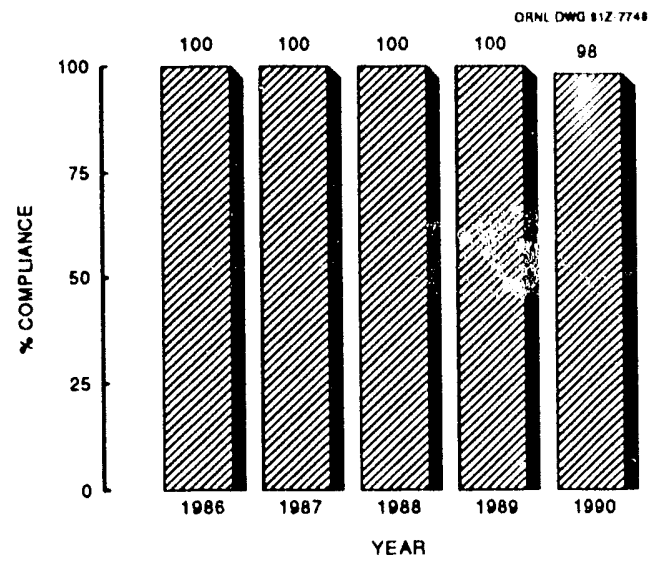

Fig. 3.51. NPDES compliance for total residual chlorine at the X-616 chromate treatment facility (004).

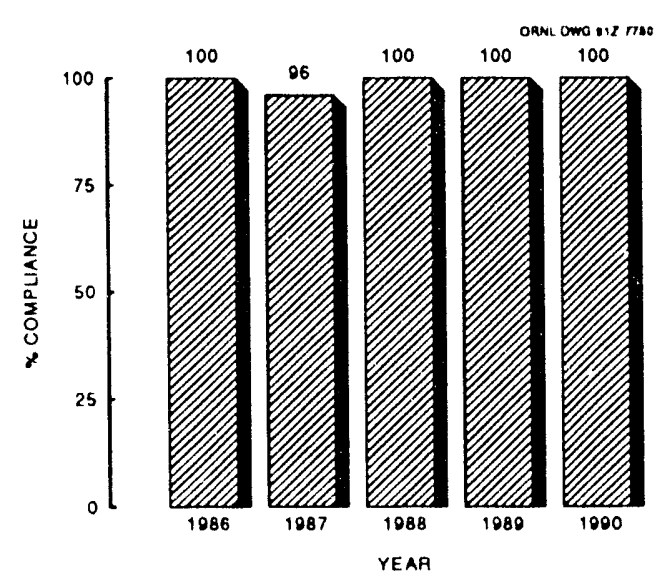

Fig. 3.52. NPDES compliance for trichloroethylene at the $\mathrm{X}-616$ chromate treatment facility (004). 


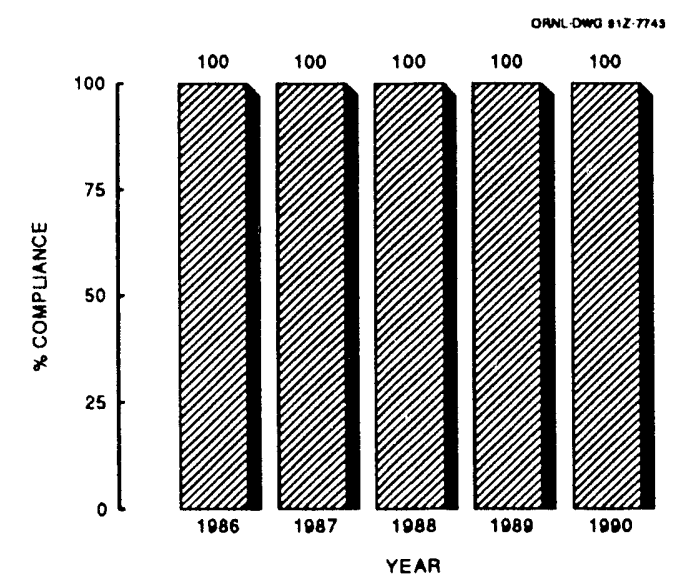

Fig. 3.53. NPDES compliance for $\mathrm{pH}$ at the $\mathrm{X}-616$ chromate treatment facility (004).

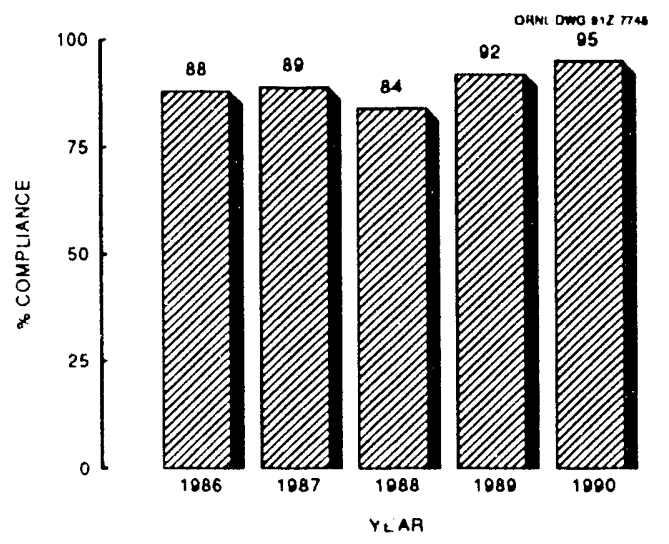

Fig. 3.54. NDDS compliance for total suspended solids at the north holding pond (009).

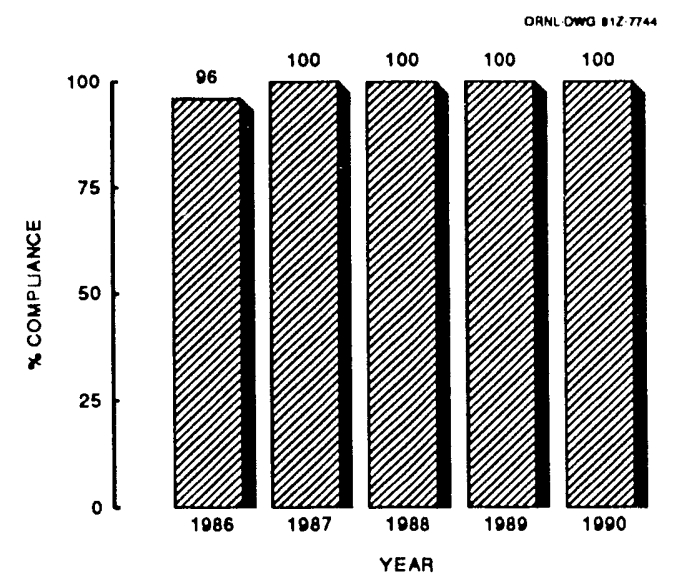

Fig. 3.55. NPDES compliance for oil and grease at the north holding pond (009).

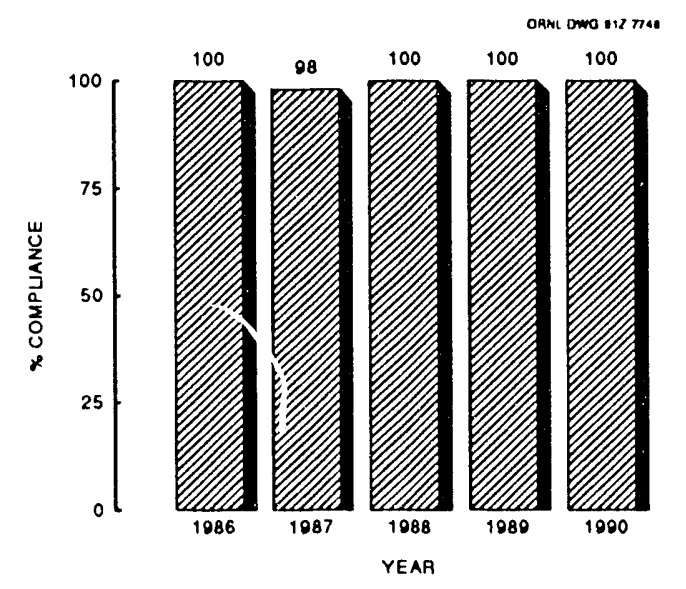

Fig. 3.56. NPDES compliance for total residual chlorine at the north holding pond (009). 


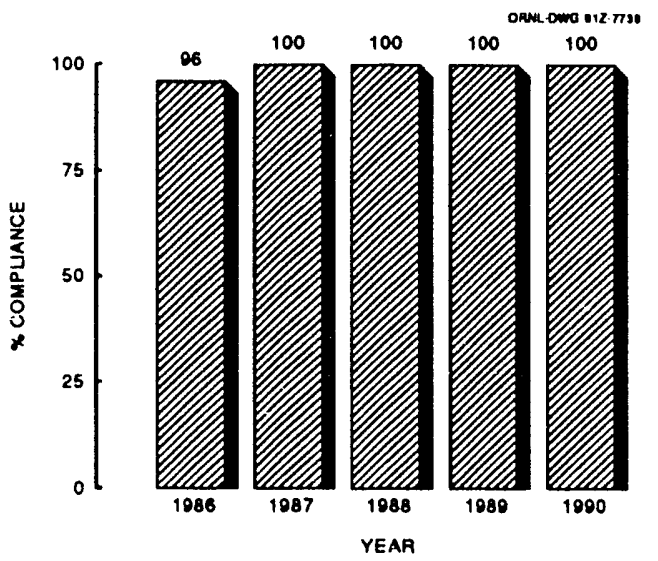

Fig. 3.57. NPDES compliance for $\mathrm{pH}$ at the north holding pond (009).

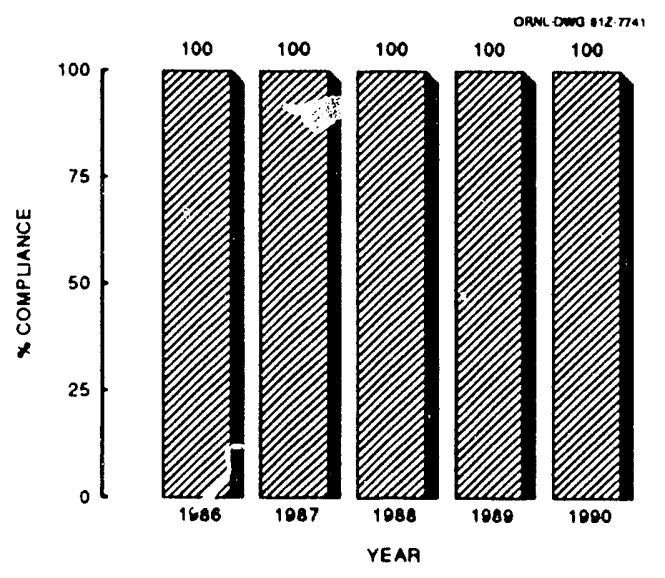

Fig. 3.58. NPDES compliance for ofl and grease at the west drainage ditch (010).

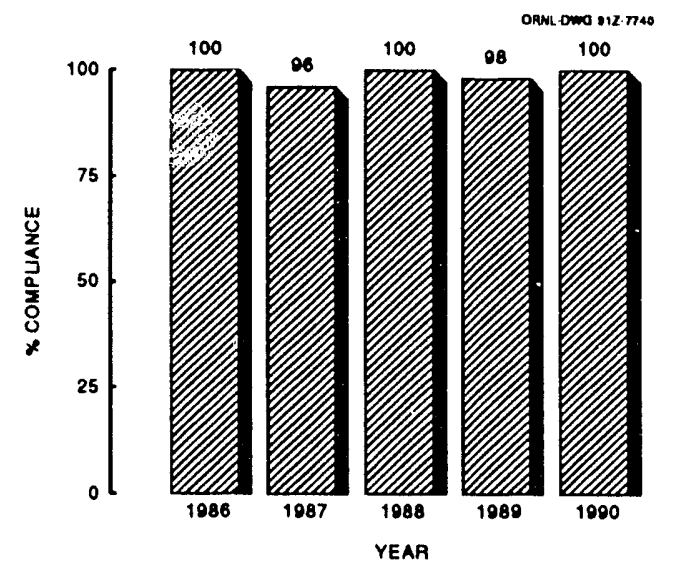

Fig. 3.59. NPDES compliance for $\mathrm{pH}$ at the west drainage ditch (010).

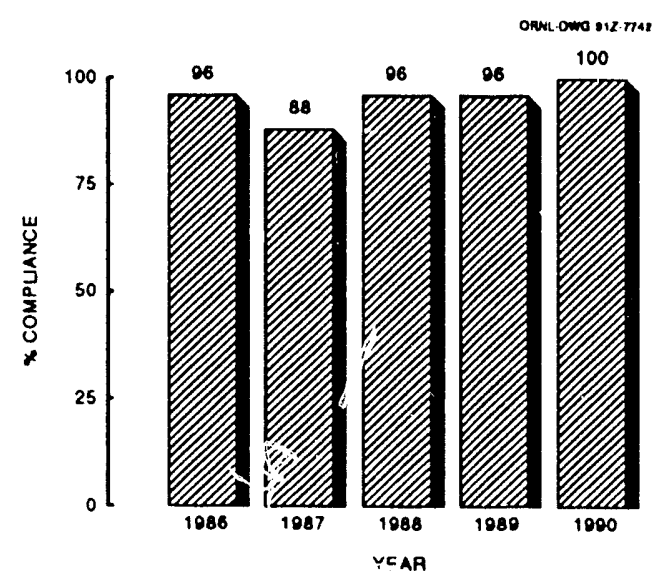

Fig. 3.60. NPDES compliance for $\mathrm{pH}$ at the northeast drainage ditch (011). 


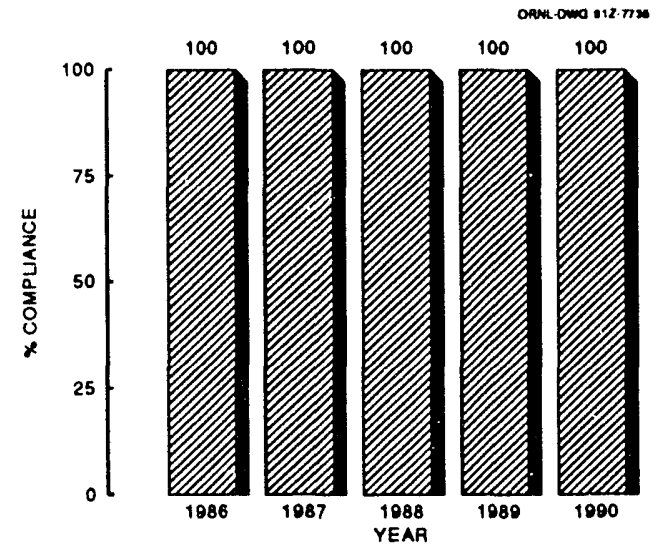

Fig. 3.61. NPDES compliance for oil and grease at the northeast drainage ditch (011).

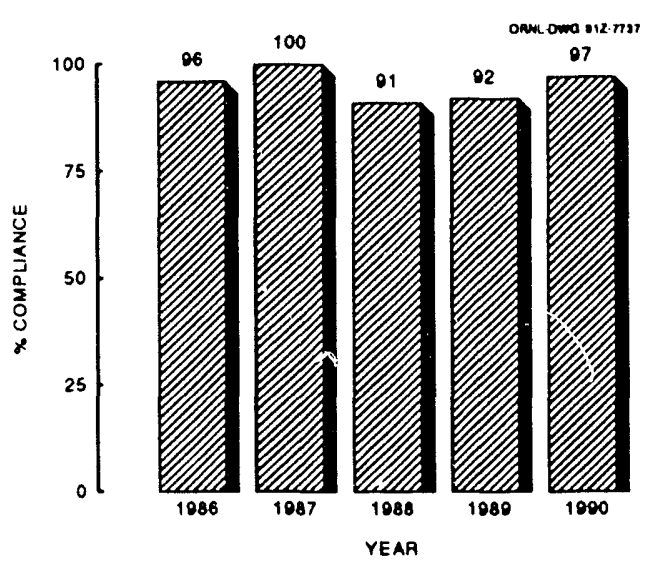

Fig. 3.62. NPDES complian :e for total suspended sollds at GCEP pond G001.

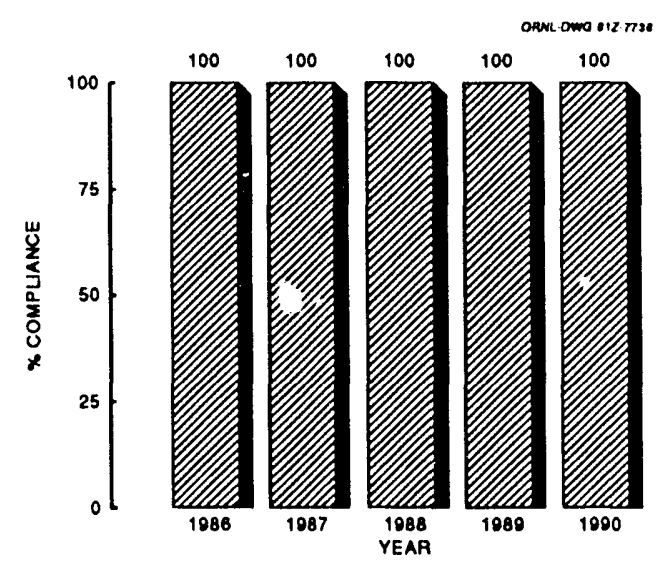

Fig. 3.63. NPDES compliance for oil and grease at GCEP pond G001.

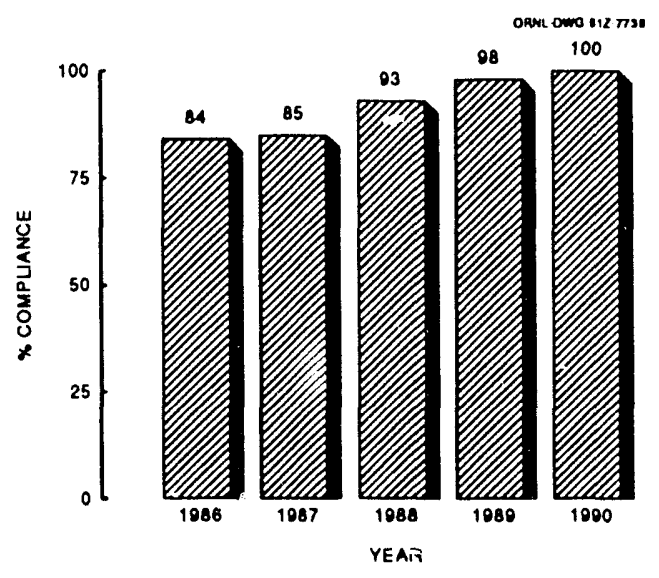

Fig. 3.64. NPDES compliance for $\mathrm{pH}$ at GCEP pond G001. 


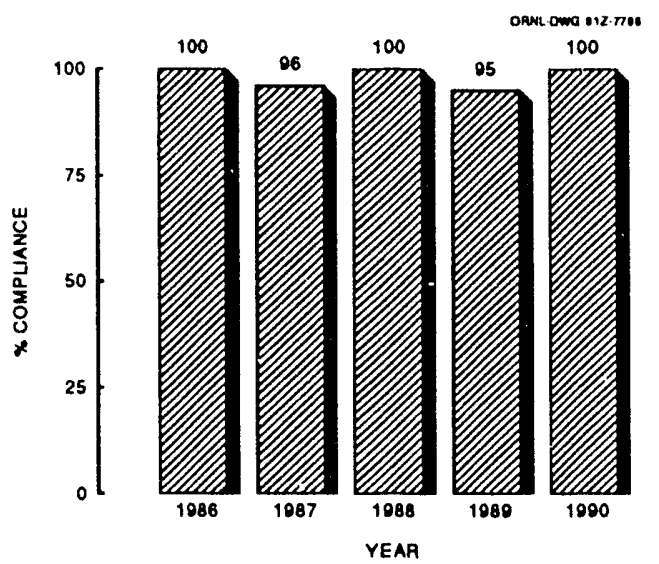

Fig. 3.65. NPDES compliance for total suspended solids at GCEP pond G002.

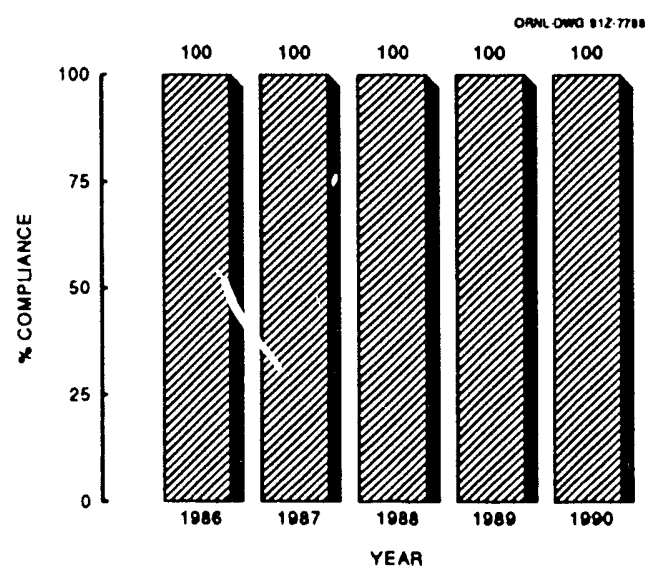

Fig. 3.66. NPDES compllance for oll and grease at GCEP pond G002.

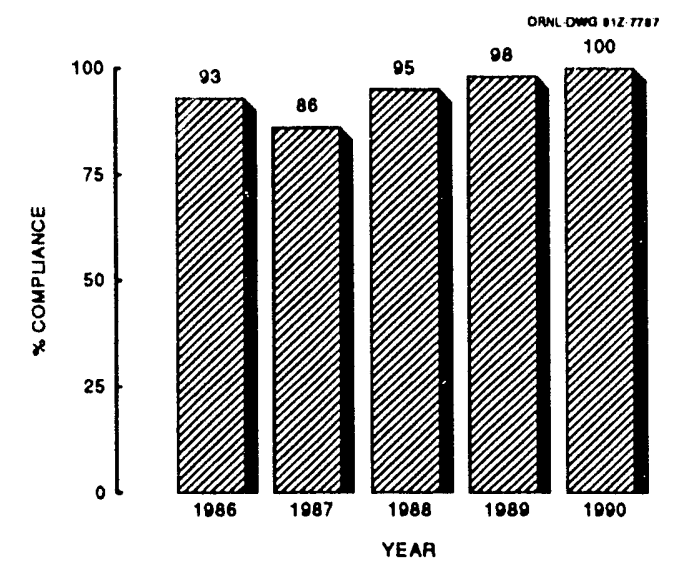

Fig. 3.67. NPDES compliance for $\mathrm{pH}$ at GCEP pond $\mathrm{G002}$. 
T2

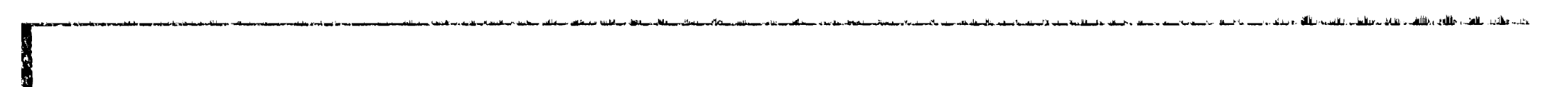




\section{GROUNDWATER}

Groundwater-monitoring activities at PORTS are directed toward two general goals. The first is to define comprehensively the geology, hydrology, and hydrogeology in the vicinity of the plant site. Since 1987, efforts have been directed toward a comprehensive definition of the hydrologic flow system in the watershed local to the PORTS site. This is necessary to understand the dynamics of the hydrologic cycle and the flow systems that define the occurrence and movement of groundwater and its vulnerability to contamination. Refining the model of the site hydrologic flow systems will be an ongoing goal of the Groundwater Protection Program as defined by DOE Order 5400.1 .

The second general goal is to define the effects that activities at the DOE site have on groundwater quality. One of the probable sources of groundwater contamination has been land disposal sites. These sites have received the most attention in the Groundwater Monitoring Program because they have been the major contributors to groundwater contamination on the site. The highest priority of the Groundwater Monitoring Program during the last $\mathrm{few}$ years has been to identify the contaminants associated with three inactive RCRA hazardous land disposal units and the extent and rate of movement of the contaminant plumes. That task was completed in 1989. It was determined that the contamination is within site boundaries and does not threaten to migrate off-site. Other land disposal units on-site are of secondary priority and are being considered as part of investigations that will evaluate the effect of all plant-site operations on groundwater quality.

Much of the groundwater investigative activity and schedules are defined by a Consent Decree between the state of Ohio and DOE (effective December 1, 1988) and an Adminstrative Consent Order between EPA and DOE (effective November 1989). The approach is based on guidelines for a RCRA Currective Action Plan, but because the
PORTS site is large, complex, and resource intensive, the plan is being implemented in four parts called "quadrants." The quadrants divide the plant site into four geographic areas based roughly on groundwater divides and drainage patterns. The parallel effort to define the comprehensive geology and the hydrologic flow system around the plant site provides cohesiveness to this four-part approach. Other investigative programs, which have been active for about 10 years, are the Off-Site Residential Drinking Water Monitoring Program and the X-735 Sanitary Landfill Monitoring Program. Each of these programs is discussed further in Subsect. 4.1.

\subsection{GROUNDWATER MONITORING PROGRAM DESCRIPTIONS}

\subsubsection{Programs}

\subsubsection{RCRA hazardous waste site monitoring}

Groundwater-monitoring requirements applicable to interim status facilities, including detection and assessment programs, are specified in 40 CFR. Portsmouth has four RCRA land disposal units affected by these requirements: the X-616 chromium sludge surface impoundments, the X-231 B oil biodegradation plot, the $X-749$ low-level waste landfill, and the X-701B holding pond. All four of these sitcs will be closed as RCRA hazardous waste land disposal units. Detection monitoring has been performed on the sites, and contamination was detected at the X-231B, X-749, and X-701B units; assessment monitoring is now being performed. The contaminants consisted mainly of trichloroethene and low concentrations of the low-energy beta emitter ${ }^{99} \mathrm{Tc}$. Though no solvent or radionuclide contamination has been detected at the X-616 site, the groundwater exceeded indicator parameter thesesholds. Groundwater quality assessments were therefore 
required at all four sites. The assessments were begun in 1988 and completed in 1989 at X-231B, X-749, and $\mathrm{X}-701 \mathrm{~B}$. Assessment monitoring of these units was performed quarterly in 1990. The assessments appear to indicate elevated levels of chromium in groundwater at X-616. In 1990, ground water was monitored quarterly for total chromium.

\subsubsection{Groundwater Quality Assessment program}

The goal of interim status assessment monitoring is to determine the concentration and the rate and extent of migration of hazardous waste or hazardous-waste constituents from the facility in groundwater at the site. The purpose of assessment monitoring is to provide information to support future decisions about corrective action; characterization of contaminant plumes in terms of Appendix IX (40 CFR Part 264) constituents is developed through the permitting or negotiations process. Assessment monitoring may be triggered by detection monitoring or may be initiated from the outset at interim status sites where groundwater contamination is suspected or known to be present. In either case, assessment monitoring must be conducted quarterly in accordance with a Groundwater Quality Assessment (GWQA) Plan. This plan must specify the monitoring-well network, sampling and analysis procedures, procedures for data evaluation, and an implementation schedule. The completed GWQA for the four RCRA units at PORTS was provided to the Ohio Environmental Protection Agency (OEPA) in June 1989 and was approved $b$; OEPA in August 1989 (Geraughty and Miller, Inc. June 1989). A descriptive summary of these assessment activities follows.

In late August 1988, a GWQA investigation was implemented at the four previously mentioned RCRA-regulated facilities: X-701B, X-749, X-231B, and $X-616$. The results of the investigation indicate that only the Gallia Sand Formation (the principal water-bearing formation on-site) exhibits significant contamination with trichloroethylene (TCE) at $X-231 B, X-749$, and $X-701 B$. The rate of plume migration, determined by using both field measurements and flow model simulations, ranges from 0.1 to $0.3 \mathrm{ft} / \mathrm{d}$. The leading edge of plumes emanating from the three RCRA facilities is located approximately $300 \mathrm{~m}(1000 \mathrm{ft})$ from X-231 B, $480 \mathrm{~m}$ $(1600 \mathrm{ft})$ from $X-749$, and $660 \mathrm{~m}(2200 \mathrm{ft})$ from
$\mathrm{X}-701 \mathrm{~B}$. The investigation results pointed to important factors controlling the groundwater flow and transport system at these RCRA units: (1) the thickness and hydraulic conductivity of the Gallia Sand Formation, (2) the thickness and low vertical conductivity of the Sunbury Shale Formation, (3) the presence of a storm drain system, and (4) the low hydraulic conductivity of the Minford Clay Formation.

Based upon the results of the GWQA, a quarterly assessment monitoring plan was proposed for three of the RCRA facilities. The plan includes sampling 21 wells at X-701B, 18 wells at X-749 and 12 wells at $X-231 B$ for volatile organic compounds (VOCs) (SW-846 Methods Nos. 8240 and 8010), gross alpha, gross beta, uranium, and technetium beta. Twelve wells at X-616 were sampled for total chromium, which is the indicator constituent of this unit. Surface water monitoring was conducted at Little Beaver Creek, Big Run Creek, and an unamed southwest drainage as part of the assessment program. In addition, water level elevation measurements were taken in more than 250 monitoring wells (Fig. 4.1) to determine groundwater flow directions and detect differences in contaminant migration rates.

The assessment groundwater monitoring networks at X-701B, X-749, and X-231B were designed to monitor indicator concentration and movement. To accomplish those objectives, monitoring well locations were selected within the central nortion of, at the edge of, downgradient of, and bek $v$ the plume in the Berea Sandstone Member. The plum: wells monitor the maximum contaminant concentration; fringe wells quantify the change (if any) at the edge of the plume; downgradient wells will detect additional downgradient movement in the Gallia; and the Berea wells will detect contamina.at migration across the Sunbury Shale.

The water-table and potentiometric-surface maps, the geologic outcrop paiterns, and the observed contamination distritution indicate three principal locations of discharge for groundwater in the Gallia and the Berea Aquifer beneath PORTS: Little Beaver Creek on the north and east, Big Run Creck on the southeast, and the two unnamed tributaries to the west. Because the waste units are constructed in the Minford, this formation provides a vertical pathway beneath the facilities to the Gallia Sand, the most permeable unit beneath PORTS. The Gallia 
ORNL-DWG 87-10 41 R3

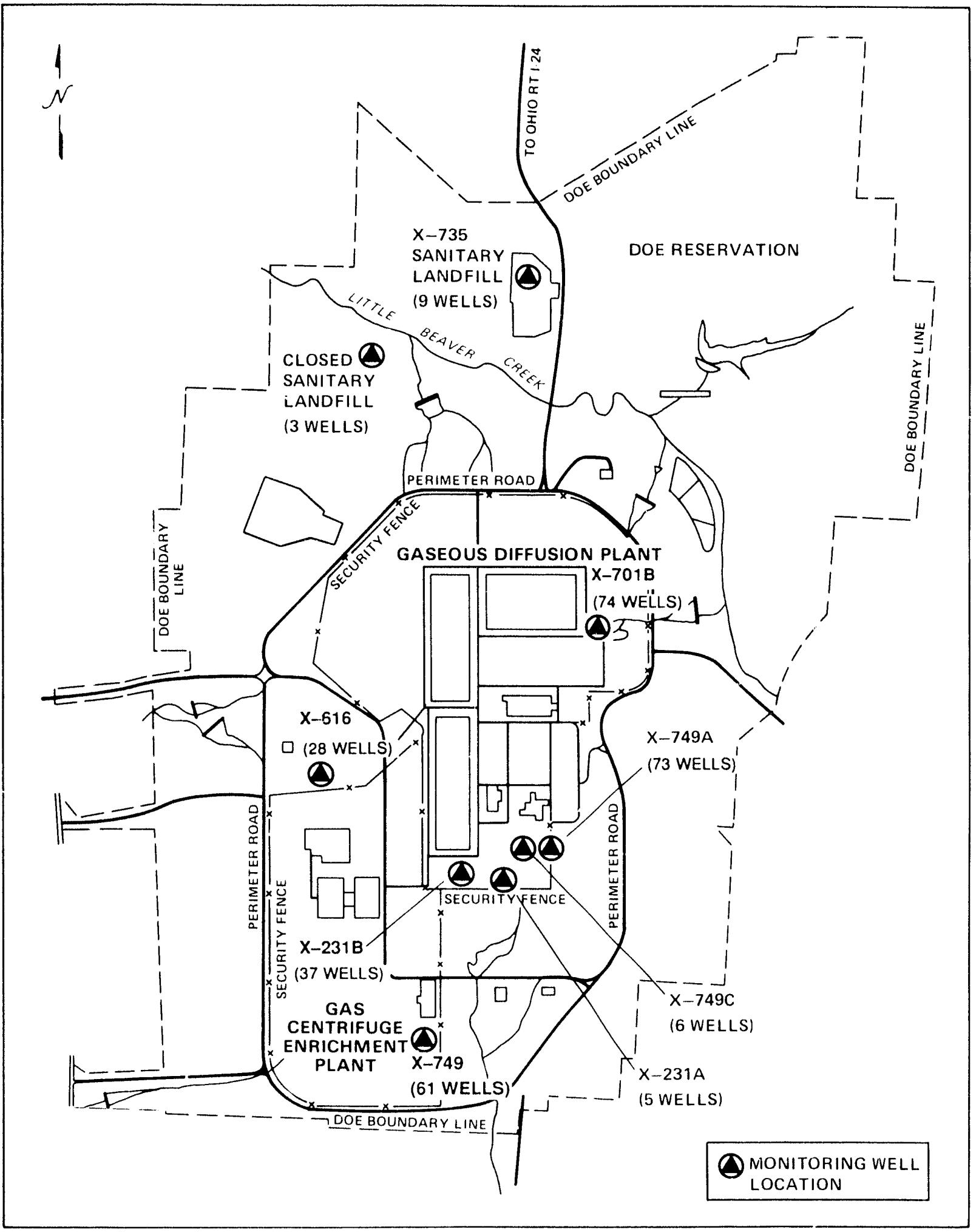

Fig. 4.:. Groundwater-monitoring well system and surface-water-moritoring locations at PORTS. 
water-table flow system carries these contaminants downgradient following the thicker sand deposits. The storm drain system depresses the water table, dewaters the Minford silt, and locally captures groundwater and contaminants from the Gallia. Although a downward vertical gradient is observed between the Gallia and the underlying Berea, the low vertical hydraulic conductivity, substantial thickness, and wide areal extent of the Sunbury Shale present an effective barrier restricting vertical communication between the Gallia and Berea. This limits the vertical migration of contaminants into the Berea. Only small concentrations at or near the analytical detection limit for dichloroethane (DCA) were detected in the Berea. This is consistent with the long-term aquifer test results showing that pumping from the Gallia caused no vertical hydraulic response in the Berea or Minford.

The X-701B unit contains the highest level of VOcs of the four RCRA units. VOC contaminents found at 701B are TCE, 1,1,1,-trichloroethane, and 1,1,2,-trichloroethane (TCA), the dichlorethylenes (DCE), DCA, Freon-113, tetrachloroethylene, and vinyl chloride.

Of the VOCs at X-701B, TCE is present in the highest concentration. All other contamination is contained within the TCE plume. The thickness of the Gallia controls contaminant migration at the unit. A narrow band of thicker Gallia deposits extends from southeast of the holding pond to the northeast corner of the X-744G building and then east across Perimeter Road to Little Beaver Creek. The Gallia deposits thin to less than $2 \mathrm{ft}$ just west of Little Beaver Creek. The highest concentration of TCE detected is $2,000,000 \mathrm{ppb}$. Samples logs do not show any evidence of free product. Four other wells have TCE concentrations exceeding $1,000 \mathrm{ppb}$. The oiher VOC constituents were occasionly detected in wells comir $_{1}$-leted in the plume. The high TCE concentrations may have masked the concentration or presence of the other VOC constituents.

Three Berea wells were monitored quarterly at $X-701 B$; none of the wells showed any VOC contamination except for a minor occurence of the gasoline constituents toluene and xylenes. This is probably due to contamination from the gasoline-powered generator used to power the submersible pump during purging operations.
The groundwater contamination at X-701B is characterized by a long, narrow plume predominantly of VOCs stretching from the holding pond to Little Beaver Creek. Contamination was detected in water samples taken in Little Beaver Creek, indicating discharge from the Gallia. Groundwater velocity calculations in the Gallia estimate a log mean velocity of $0.2 \mathrm{ft} /$ day. Based on this velocity, the travel time for contaminants from the holding pond to the creek is about 25 years. Groundwater velocities in the Berea range from 0.048 to $0.15 \mathrm{ft} /$ day.

Particle-tracking results from model simulation exhibit a range of travel times from 15 to 30 years from X-701 B to Little Beaver Creek.

Groundwater at X-749 exhibited elevated levels of VOCs. The X-749 area is similar to X-701B in its hydrogeologic framework. The distribution and thickness of the Gallia control the flow and contaminant migration from the facility. The thickest Gallia deposits occur at the southwest corner of the landfill and extend to the southeast and to the west. To the east, the Gallia thins, and contaminant migration has been limited because of the low permeability of the Minford.

The flow system at X-749 is characterized by a north-south-trending divide along the western edge of the landfill. Groundwater on the eastern half of the facility flows to Big Run Creek, and on the western half to the unnamed tributary to the southwest. In the southwest corner of the landfill, groundwater is influenced by a stormwater runoff drain. In the Berea, flow directions are very sinilar to those in the Gallia. At this facility, the Sunbury is approximately $1.5 \mathrm{~m}$ $(5 \mathrm{ft})$ thick over much of the area. Observed head differences between the Gallia and the Berea are still approximately 3 to $6.1 \mathrm{~m}$ (10 to $15 \mathrm{ft}$ ).

VOC contamination of groundwater extends to the southwest from the western portion of the facility and to the southeast and east from the eastern portion. Radionuclide plumes at X-749 exhibit the same configuration as the VOC plumes. The VOC contamination is composed of TCE, TCA, DCEs, and vinyl chloride. The contaminants with the highest concentrations are TCE and TCA. The highest TCE concentrations are $9700 \mathrm{ppb}$ and $8500 \mathrm{ppb}$, and all other concentrations are one or more orders of magnitude less. Peak concentrations of both technetium (532 pCi/L) and uranium (142 ppb) occur on the west side of the unit. 
Quarterly sampling includes four Berea wells. There was a consistently low occurrence of $1,1,-\mathrm{DCA}$ and $1,2,-$ DCA in a Berea well. The highest $1,1,-D C A$ concentration was $6.8 \mathrm{ppb}$; there is no maximum concentration level (MCL) for 1,1-DCA. The maximum value of $1,2 \mathrm{DCA}$ was $1.0 \mathrm{ppb}$, which is below the MCL of $5.0 \mathrm{ppb}$. Xylenes were detected in the second quarter sampling; they are believed to come from the gasoline-powered submersible pump. No other VOCs have been detected at X-749 Berea wells during 1990.

Groundwater velocities in the Gallia range from 0.04 to $3.8 \mathrm{ft} / \mathrm{day}$; in the Berea, from 0.054 to $1.76 \mathrm{ft} /$ day. Particle-tracking analyses predict complex patterns of contaminant migration.

Contaminants on the west side of the landfill migrate to the southwest and discharge to the storm drain in approximately 20 years. In the southern end, particles migrate to the southeast and Big Run Creek.

The X-231B oil biodegradation plots were used from 1976 to 1985 for land application of waste cils and degreasing solvents containing low levels of radioactivity. The Gallia is thin beneath this

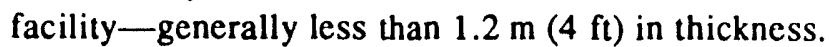
Thicker Gallia deposits occur to the southeast and east of X-231B. These thicker deposits probably represent remnants of the point bar complex associated with the meander of the ancient Portsmouth River.

Groundwater flow in the Gallia, Minford, and Berea exhibits a southeastward gradient. The horizontal gradient in the Gallia is very low because of the close proximity of the major east-west divide and the higher hydraulic conductivity exhibited by the Gallia south and east of the facility. The Sunbury is 3 to $3.6 \mathrm{~m}$ (10 to $12 \mathrm{ft}$ ) thick, thins to the west, and is absent over much of the western portion of PORTS. Vertical gradients between the Gallia and Berea are steep and average $1.5 \mathrm{~m}(5.0-\mathrm{ft})$ head loss across the Sunbury. This head difference and gradient decrease to the northeast, due to thinning of the Sunbury.

The VOC contamination at X-231B is limited to the Gallia unit. The highest contaminant concentrations (TCE) are in the tens to hundreds of parts per billion range. Other VOCs detected at X-2341 B are DCEs, TCA and DCA. The northern boundary of TCE is around the south end of the $\mathrm{X}-326$ building and extends through X-626 to the edges of the X-2270A parking lot and south to near the X-230K Holding Pond. The TCE plume underlies all of $X-744 \mathrm{~K}$ and the western portions of the X-600A Coal Pile Yard and X-231A. A storm drain runs north to south through the plume and appears to be influencing the migration of contarninants away from this RCRA unit. Radionuclide contamination is not widespread; technetium exhibited maximum concentrations of $74 \mathrm{pCi} / \mathrm{L}$ (well below the $900 \mathrm{pCi} / \mathrm{L}$ drinking water standard). The Berea is unaffected by contamination at X-231B. Some of the Berea wells at $X-231 B$ have minor occurrences of gasoline constituents similiar to those in the Berea wells at the other monitoring well networks. The

gasoline-powered submersible pump used for purging operations is believed to be the source of the contamination.

Groundwater flow is southeast toward the $X-230 \mathrm{~K}$ holding pond. Groundwater velocities in the Gallia at X-231B range from 0.014 to $5.6 \mathrm{ft} /$ day with a $\log$ mean velocity of $0.28 \mathrm{ft} /$ day. In the Berea, the velocities range from 0.054 to $0.33 \mathrm{ft} /$ day, with a $\log$ mean velocity of $0.10 \mathrm{ft} /$ day. The particle-tracking analyses performed indicate contaminant migration to the southeast and contaminant discharge into the $\mathrm{X}-230 \mathrm{~K}$ holding pond in 15 to 20 years.

Surface water monitoring from Little Beaver Creek, Big Run Creek, and the unnamed southwest drainage has been conducted as part of assessment monitoring at X-701B, X231B, and X-749.

Little Beaver Creek was sampled throughout the year in locations LBC-SW01 through LBC-SW03. Maximum values were $220 \mathrm{ppb}$ at LBC-SW-1, $71 \mathrm{ppb}$ at LBC-SW02, and $17 \mathrm{ppb}$ at LBC-SW03. These values were highest in the fourth quarter. An additonal sampling site, labeled LBC-SW04, was added in the third quarter at the northwest property line. No VOC contaminaton was cietected at LBC-SW04.

Big Run Creek was monitored at two locations (BRC-SW01 and BRC-SW02), neither of which show any VOC contamination.

In the southwest corner of the plant site, an unnamed drainage was monitored at two locations (UND-SW01 and UND-SW02). At the location inside the perimeter road, UND-SW01, minor occurrences of TCE and trichlorofluoromethane were detected. Both VOC constituents were below $5.0 \mathrm{ppb}$.

Surface water sampling will continue on a quarterly basis during the assessment monitoring. The 
surface water monitoring program will be expanded and four sampling locations will be added: three locations in the west Drainage Ditch and a site below the north Holding Pond.

The $X-616$ chromium sludge surface impoundments area was used to store precipitant from the treatment of the recirculating cooling water (RCW). Approximately one million gal of RCW have been processed daily since 1976 . The Gallia is 1.2 to $1.8 \mathrm{~m} \mathrm{(4}$ to $6 \mathrm{ft}$ ) thick over much of the facility but thins to the west and the northeast. The Sunbury Shale is absent under X-616, and the bedrock surface is composed of the upper portion of the Berea. This bedrock surface is fairly flat except for a small knob located beneath the northwest corner of the lagoons. Beneath X-616 the Gallia and the Berea essentially act as one unit. The absence of the confining unit minimizes the head difference between the two units. As a result, groundwater flow directions in these units are similar. The Gallia and Berea flow north and west away from the lagoons.

Based upon the presence of chromium in excess of the MCL in Appendix IX analyses performed on four wells at X-616, chromium is the indicator parameter of this unit. The first quarter results show that $75 \%$ of the wells sampled in the vicinity of $\mathrm{X}-616$ contained chromium at levels greater than 50 ppb. All wells were sampled again during the second quarter, this time for both total and hexavalent chromium. In addition, 15 background wells distant from the X-616 area were sampled for total and hexavalent chromium. The results of the hexavalent analyses in all samples were at or below the detection limit of $10 \mathrm{ppb}$. The total chromium results of the background wells indicated 7 of the 8 Gallia and 4 of the 7 Berea wells also contained over $50 \mathrm{ppb}$ chromium. Furthermore, the mean of the total chromium values in the background wells exceeds the mean of total chromium values in the X-616 wells. In addition, two of the three highest highest total chromium values are from the background wells. A statistical analysis (tolerance interval) was conducted on the second quarter results and revealed no significant evidence of chromium contamination at X-616 (Geraghty \& Miller, Inc. 1990a). However, the results of ongoing quarterly sampling at X-616 and background will be used in further statistical analyses.

\subsubsection{Solid waste landfill monitoring (X-735 sanitary landfill)}

PORTS has conducted sampling and analyses of wells at X-735 from 1977 to the present. The groundwater monitoring at X-735 is defined and required by the landfill license in effect for the facility. The original groundwater monitoring network consisted of eight monitoring wells encircling the landfill. The exact construction and integrity of the wells was unknown. To comply with current solid waste regulations, six monitoring wells were installed around the perimeter of X-735 in July 1990. The new wells were drilled, installed, developed, and sampled to comply with RCRA protocols.

The local geology consists of unconsolidated deposits (Minford and Gallia) situated above bedrock. The Minford comprises two layers: an upper layer of clay and silty clay and a lower unit composed of siit and fine sand. The Minford thickness ranges from 16 to $29 \mathrm{ft}$. The Gallia consists of a medium-grained sand with occasional lenses of cobbles and pebbles. The Gallia is thickest (12 feet) beneath the northwest corner of the landfill and thins towards the south to a thickness of $2 \mathrm{ft}$. Bedrock in this area is the Cuyahoga Shale, which generally occurs as a black shale with gray siltstone interbeds.

The ground water flow direction is predominantly toward the southwest. Hydraulic conductivities and transmissivities are generally higher beneath the northwest corner of the landfill and decrease to the south and east. Hydraulic conductivity values range from $1 \mathrm{ft} / \mathrm{min}$ to $3 \times 10(-3)$. The highest transmissivity is $3.2 \mathrm{ft}(\mathrm{sq}) / \mathrm{min}$ (northwest) and the lowest is $0.02 \mathrm{ft}(\mathrm{sq}) / \mathrm{min}$ (south).

Groundwater samples were collected from the six wells during the third and fourth quarter sampling events in 1990. Samples were collected for VOCs (SW 846- Method Nos. 8240 and 8010), total uranium, technetium beta, gross beta and gross alpha. All groundwater results for the X-735 wells were below detection limits for each VOC constituent. The highest gross alpha value was $70 \mathrm{pCi} / \mathrm{L}$ and the highest gross beta value was $33 \mathrm{pCi} / \mathrm{L}$.

Four wells were sampled for Appendix IX parameters. All groundwater results for the Appendix IX VOCs, acid and base neutrals, pesticides, herbicides, PCBs, and chlorinated dioxons and furans were below detection limits. 


\subsubsection{Off-site monitoring}

Monitoring of the local residential sanitary water systems began in 1979. This monitoring is conducted semiannually on springs and private wells that serve as the source of sanitary water for private households near PORTS (see Fig. 4.2 and Table 4.1). Results of the analyses are routinely communicated to the residents. Parameters typically monitored include uranium, technetium, total alpha, and total beta. Analysis for the preserice of organics was added in 1986. The monitored parameters have not been detected above maximum concentration levels in any of the sampling events. The results are shown in Tables 4.2 and 4.3 .

\subsubsection{Sampling and Analysis}

Groundwater sampling and analysis follows standard procedures for sample collection, sample preservation and handling, chain of custody, sample analysis, quality control/quality assurance (QC/QA), and data quality evaluation. Sampling and analysis of all groundwater wells is specified in a Groundwater Sampling and Analysis Plan and Groundwater Monitoring Plan (Geraghty and Miller 1990).

\subsubsection{Well Construction and Abandonment}

Well installation standards include procedures, specifications, and documentation requirements for

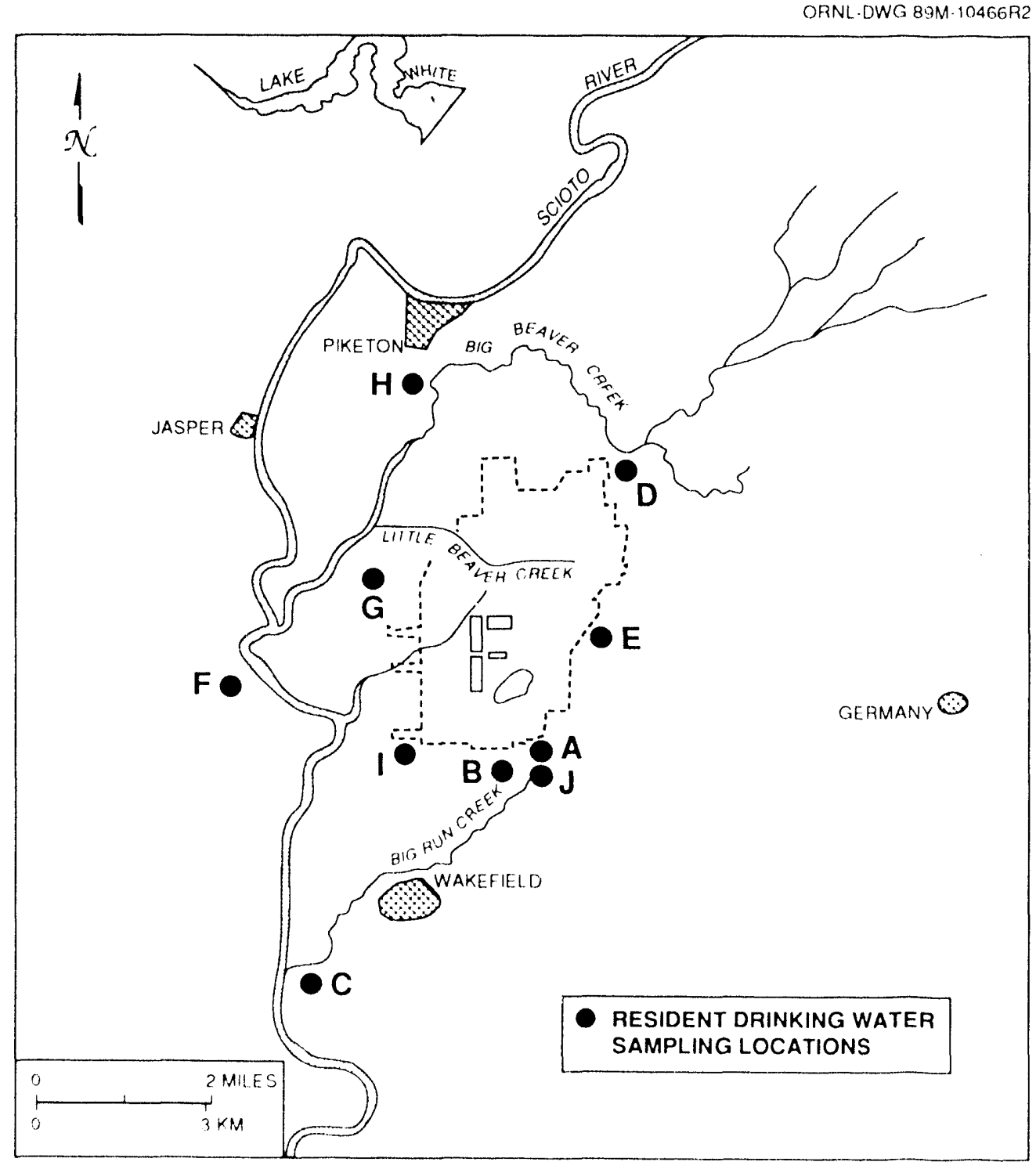

Fig. 4.2. Residential drinking-water-monitoring sites. 
Table 4.1. Residential drinking water location code identification

\begin{tabular}{lll}
\hline \multicolumn{1}{c}{ Location $^{\text {a }}$} & Source & $\begin{array}{c}\text { Location } \\
\text { code }\end{array}$ \\
\hline Bailey Chapel Road & Well & A \\
Big Run Road & Spring & B \\
Wakefield & Well & C \\
Taylor Hollow Road & Cistern & D \\
McCorkle Road & Well & E \\
Route 104 & Well & F \\
U.S. Highway 23 & Well & G \\
Wakefield Mound Road & Well & H \\
Wakefield Mound Road & Well & I \\
Bailey Chapel Road & 2 Wells & J \\
\hline
\end{tabular}

${ }^{a}$ See Fig. 4.2.

Table 4.2. Radionuclides tested in residential drinking water

\begin{tabular}{lcccc}
\hline & Number of & \multicolumn{3}{c}{ Concentration } \\
\cline { 3 - 5 } Parameter & samples & Max & Min & Av \\
\hline Uranium (mg/L) & 20 & 0.005 & $<0.001$ & 0.001 \\
Alpha (pCi/L) & 20 & 5.0 & -9.0 & 0.0 \\
Beta (pCi/L) & 20 & 15.0 & -3.0 & 4.0 \\
Technetium (pCi/L) & 20 & 22.0 & -1.0 & 7.0 \\
Radium (pCi/L) & & & & \\
\hline
\end{tabular}

Table 4.3. Halogenated volatile organics tested in residential drinking water

\begin{tabular}{lcccc}
\hline \multicolumn{1}{c}{ Parameter } & $\begin{array}{c}\text { Number of } \\
\text { samples }\end{array}$ & & \multicolumn{3}{c}{$\begin{array}{c}\text { Concentration } \\
(\mu \mathrm{g} / \mathrm{L})\end{array}$} & \\
\cline { 3 - 5 } & & Max & Min & $\mathrm{Av}$ \\
\hline Methylene chloride & 20 & 0 & 0 & 0 \\
Trichlorofluoromethane & 20 & 0 & 0 & 0 \\
1,1-Dichloroethene & 20 & 0 & 0 & 0 \\
1,1-Dichloroethane & 20 & 0 & 0 & 0 \\
trans-1,2-Dichloroethene & 20 & 0 & 0 & 0 \\
Chloroform & 20 & $14.0^{a}$ & 0 & 1.0 \\
Freon 113 & 20 & 0 & 0 & 0 \\
1,2-Dichlorocthane & 20 & 0 & 0 & 0 \\
1,1,1-Trichloroethane & 20 & 0 & 0 & 0 \\
Carbon tetrachloride & 20 & 2.0 & 0 & 0 \\
Bromodichloromethane & 20 & $13.0^{\circ}$ & 0 & 1.0 \\
Trichlorocthene & 20 & 0 & 0 & 0 \\
Dibromochloromethane & 20 & $13.0^{\circ}$ & 0 & 1 \\
Bromoform & 20 & 0 & 0 & 0 \\
Tetrachlorocthene & 20 & 0 & 0 & 0 \\
\hline
\end{tabular}

These maximum values, all of which were from Pike County sanitary water, are by-products of chlorination. 
monitoring wells at PORTS. Environmental surveillance procedures relating to well installation have been published (Kimbrough, Long, and McMahon Sept. 1, 1988). Generally, monitoring wells installed at Portsmouth have been $5.08-\mathrm{cm}$ (2-in.) stainless steel and constructed with appropriate annular space screen packing and sealant. Geologic logging and as-built documentation are required for each well construction. Each well is properly developed to restore (as nearly as possible) the flow characteristics representative of the original water-bearing formation being monitored.

Well abandonment procedures apply to the decommissioning of damaged, unusable, or no-longer-needed groundwater-monitoring and investigation wells. Well inspection and maintenance reports identify wells that are damaged or unusable. Wells also must be removed because of construction or site closure activities. When wells are identified for abandonment, plans are developed that include scheduling plugging and abandonment aciivities, obtaining subcontractor services for the plugging and abandonment, obtaining engineering support for field operations oversight, and ensuring that the subcontractor complies with plugging and abandonment procedures.

\subsection{GEOLOGIC SETTING}

\subsubsection{Geology}

PORTS occupies an upland area of southern Ohio with an average land surface elevation of $201 \mathrm{~m}$ $(670 \mathrm{ft})$ above mean sea level. The plant site sits in a mile-wide abandoned river valley situated $39 \mathrm{~m}$ (130 ft) above the level of the Scioto River to the west (Fig. 4.3). Five geologic formations control groundwater flow beneath the site: the Minford Clay/Silt, Gallia Sand, Sunbury Shale, Berea Sandstone, and Bedford Shale. The upper two formations, Minford and Gallia, were deposited during Quaternary time before and during glaciation. The youngest of these unconsolidated units is the Minford member of the Teays Formation. The Gallia member of the Teays Formation lies beneath the Minford and on top of bedrock. The Sunbury Shale of Mississippian age is the upper bedrock unit beneath most of the PORTS site and overlies the Berea Sandstone. The Bcrea Sandstone overlies the Bedford Shale. Detailed discussions of the geology and

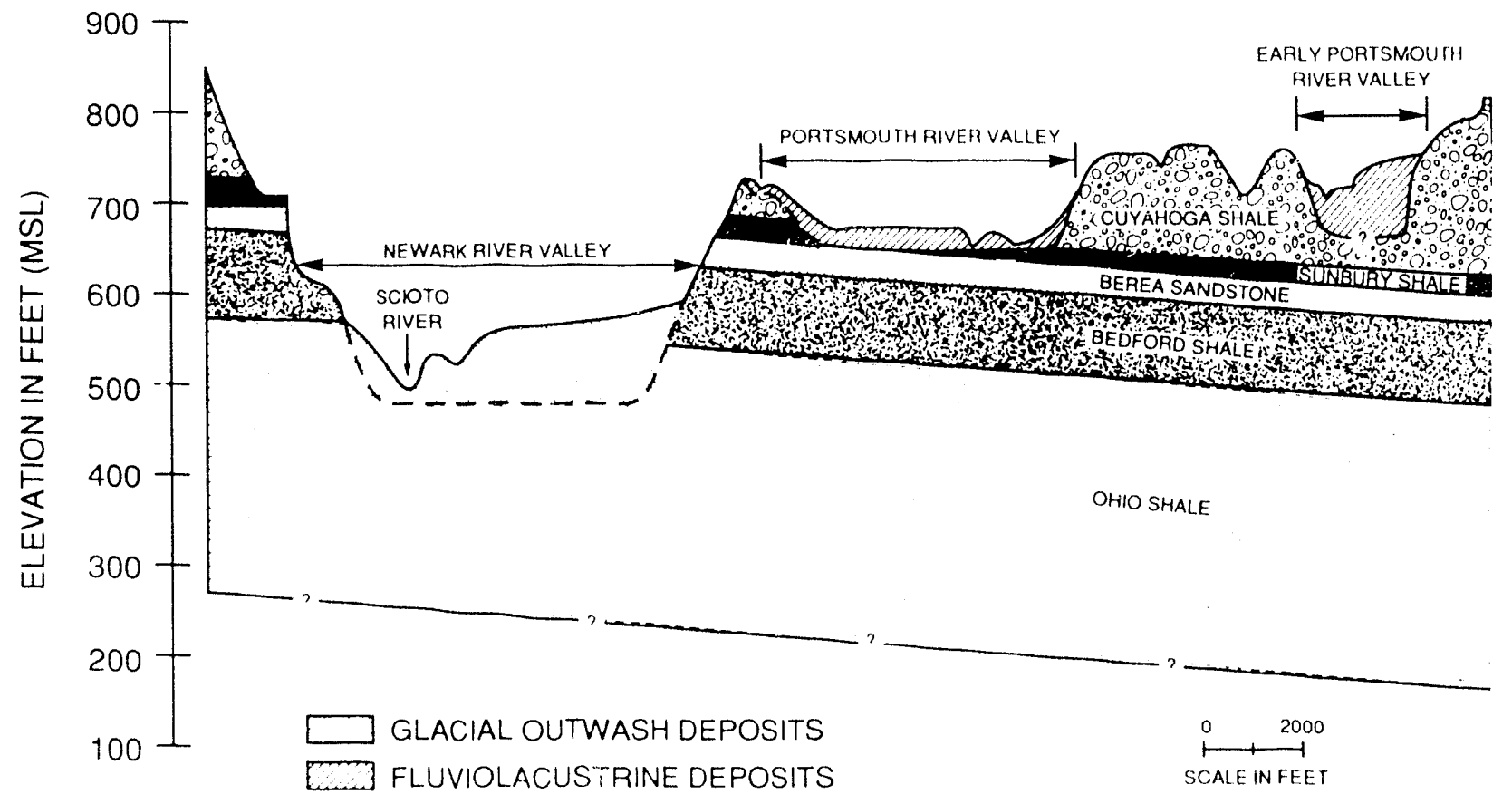

Fig. 4.3. Terrain showing geologic units that control groundwater flow beneath the P()RTS site. 
hydrogeology of PORTS have been published (Geraghty and Miller, Inc. June 1989).

\subsubsection{Hydraulic Conductivity}

The hydraulic conductivities of all hydrogeologic units at PORTS are very low. The mean hydraulic conductivity values for each hydrogeologic unit are shown in Table 4.4. The most conductive unit is the Gallia with a mean hydraulic conductivity of $3.4 \mathrm{ft} /$ day. The next most permeable formation is the Bcrea Sandstone with a mean hydraulic conductivity of $0.16 \mathrm{ft} /$ day. These values were estimated from single-well tests, most of which were conducted by Geraghty and Miller, Inc. (June 1989).

Numerous laboratory estimates of hydraulic conductivity for the Minford Clay and Silt units were performed by Law Engineering (1978). The average permeability of the Minford Clay was found to be $0.00023 \mathrm{ft} /$ day. The average permeability of the Minford Silt was found to be $0.0043 \mathrm{ft} / \mathrm{day}$. The mean hydraulic conductivity of the Bedford Shale is $0.059 \mathrm{ft} /$ day, based on 13 packer injection tests performed by Law Engineering (1978).

\subsubsection{Groundwater Flow Directions}

Groundwater flow at PORTS is controlled by interactions between the Gallia and Berea units. The flow patterns also are affected by the presence of the plant storm sewer system and the reduction in recharge caused by buildings and paved areas. The ultimate discharge area for most groundwater is Litlle Beaver Creck to the north and east, Big Run Creek to the south, and two unnamed drainages to the west. Groundwater flow patterns were analyzed using quarterly water-level measurements taken from more than 250 monitoring wells.

The potentiometric surfaces for both the Berea and Gallia units are characterized by an east-west-trending groundwater divide. Other groundwater divides are also present; these divide the flow system into four flow cells in the Gallia and three in the Berea. Groundwater flow directions in the Berea roughly parallel those in the Gallia, with a few notable exceptions outlined below. Flow directions in the Minford are roughly the same as those in the underlying Gallia.

\subsection{DATA SUMMARY AND ANALYSIS}

\subsubsection{Data Summary}

Data collected during 1990 are providec as surnmary statistics in Tables 4.1 through 4.14 of Part 2. Data are provided as volatile organic parameters and radioactivity parameters as approved in the PORTS GWQA. Volatile organic parameters are the principal chemical contaminants of groundwater on the plant site and are usually part of the contaminant "hit list" of parameters monitored to identify and track groundwater contamination. The VOC list has more than 35 parameters. The VOC summary tables for site X-701B, X-749, X-231B and surface water monitoring do not include all VOC parameters. The constituents presented in each table are the constituents consistently detected in wells completed in the contaminant plume. The constituents omitted were not consistently detected; their concentrations or presence may have been masked by high TCE concentrations. On the right hand side of the VOC and radionuclide summary tables for X-701B, X-749 and X-231B is a column heading for GWQA. This column shows the constituent concentration reported in the PORTS GWQA of Four RCRA Units (Geraghty \& Miller 1989).

Table 4.4. Hydrogeologic column at Portsmouth Gaseous Diffusion Plant

\begin{tabular}{lllc}
\hline Formation & Lithology & $\begin{array}{c}\text { Permeability } \\
(\mathrm{f} / \mathrm{d})\end{array}$ & Thickness \\
\hline Minford & Clay & $0 .(0(\mathrm{~K}) 23$ & 16.3 \\
& Silty clay & $(0.0(4) 3$ & 7.60 \\
Gallia & Sand & 3.4 & 5 \\
Sunbury & Shale & Unknown & 10 \\
Berea & Sandstone & 0.16 & 30 \\
Bedford & Shale & 0.059 & $1(0)$ \\
\hline
\end{tabular}




\subsubsection{Results and Interpretation}

At X-701B, the TCE concentrations in the central portion of the plume and at the edge of the plume are higher than reported in the GWQA. TCE was not detected in downgradient Gallia and Berea wells. At $\mathrm{X}-749$ and $231 \mathrm{~B}$, the VOC concentrations are within expected levels for each site and comparable with values produced during GWQA investigation.

Radioactivity parameters for X-701B, X-749 and $X-231 B$ are within expected levels and are comparable with values produced during the GWQA investigation, except for one sample analysis at X-701B. A high gross alpha and gross beta values were reported. The elevated gross alpha value did not correlate with the sample total uranium concentration of $0.006 \mathrm{mg} / \mathrm{L}$. Similarly, the high gross beta value did not correlate with the sample technetium beta value of $16.0 \mathrm{pCi} / \mathrm{L}$. The results were reported in the fourth sampling period of 1990 , and the well has been resampled. 


$$
\text { ". }
$$




\section{BIOLOGICAL SAMPLING}

Biological sampling at PORTS is done to assess directly the impact of operations on vegetation growing around the plant, animals that eat the vegetation, and humans who eat the vegetation and animals. This sampling provides a check on indirect assessments based on emission monitoring, atmospheric dispersion modeling, and similar methods. Annual dose assessments are calculated routinely from the results of both direct monitoring and indirect estimation, unless the direct monitoring does not detect any contamination. Since no contamination implies no radiation dose to the public, the indirect assessment is not presented in such cases. A summary of the results of each sampling program is presented here, and analytical results of individual samples are presented in Part 2. The dose assessment is presented in Sect. 7. In Part 2, the analytical detection limits are disregarded in reporting radioactivity concentrations. This improves the statistical analysis by eliminating the bias introduced by the frequently encountered detection limits, but it may mislead or confuse the casual reader with apparent "false positives" and negative concentrations.

\subsection{FOOD CROPS}

Radioactive contamination of crops may result from absorption of radioactive materials from the soil or from deposition of airborne contaminants. Since 1976 PORTS personnel have collected annual samples of food crops on a voluntary basis from privately owned farms and gardens surrounding the facility. These samples are analyzed fo: uranium, uranium alpha activity, and technetium beta activity.

\subsubsection{Program Description}

The types of crops analyzed vary from year to year because of availability, although corn and tomatoes are usually available. Crops analyzed in 1990 were corn, tomatoes, potatoes, green beans, squash, and a gourd. These crops were collected from four gardens in the vicinity of the plant and four other gardens several kilometers away that served as a source of background samples.

Food crop samples are collected in resealable plastic bags by Environmental Control Department personnel and delivered to the laboratory, where the samples are weighed before drying for analysis. Reported concentrations are based on the wet weigit because that is the way such produce is consumed. Food crops are analyzed for total uranium concentrations and for uranium alpha and technetium beta activity.

Results of the food crop analyses are reported by the laboratory to the PORTS Environmental Surveillance Section. The donors of the crop samples are informed by letter of the results of their samples. Re-sampling is performed if analytical results are significantly above the normal background range.

\subsubsection{Program Results}

All food crop samples collected in 1990 showed no radiation contamination. None of the 18 food crop samples collected in 1990 showed any detectable uranium or uranium alpha activity above normal background. Ali of the crop samples were below the lower limit of detection for technetium $(1.0 \mathrm{pCi} / \mathrm{g})$. For comparison, $1 \mathrm{pCi} / \mathrm{g}$ of ${ }^{99} \mathrm{Tc}$ is equivalent to 0.06 ppb. See Part 2 for individual results.)

\subsection{MILK AND EGGS}

No milk or egg samples were collected in 1990.

\section{$5.3 \quad$ FISH}

In 1983 PORTS started a fish-sampling program in the Scioto River and in the local creeks downstream of the site. The local creeks are of particular concern because they are small enough that 
little dilution of plant effluents occurs during dry seasons. Analytical results of fish samples are presented in Part 2.

\subsubsection{Program Description}

Fish are collected from the receiving streams and larger outfalls surrounding PORTS. During 1990, the streams sampled included several plant outfalls, Little Beaver Creek, Big Run Creek, and the Scioto River. None of the streams supports anything more than occasional sport fishing, which greatly limits the impart of slight contamination levels on human beings. The outfalls are not accessible to the public. Fish samples are collected in fish traps by environmental personnel and are analyzed for several known and potential waterborne pollutants. In 1990, samples were analyzed for total uranium, uranium alpha activity, technetium beta activity, and PCBs.

\subsubsection{Program Results}

No significant pattern of contamination was visible in the fish samples. Detectable levels of technetium and PCBs were found, but not in any specific geographic pattern and not in levels high enough to endanger public health.

None of the samples contained any detectable uranium and, with two exceptions taken in Little Beaver Creek, the uranium activity levels were .vithin the normal background range. Of the two exceptions, one sample showed no detectable uranium alpha activity, which is unusual since uranium and other alpha enitters are naturally occurring elements that should be detectable even in a pristine fish. The other (a sunfish taken from Little Beaver Creek) showed $10.3 \mathrm{pCi} / \mathrm{g}$ uranium alpha. Although that level is not high enough to be a health concern, it is noticeably higher than any of the other fish samples, most of which were collected from the same stream.

Technetium beta activities were somewhat elevated in all the fish samples in that they were detectable at all. The detected concentrations are not high enough to cause a health concern even if locally caught fish were a major component of the local dict, which they are not. Average concentrations in all the streams sampled (plant ouifalls, Little Beaver Creck, Big Run Creek, and the Scioto River) ranged between $3 \mathrm{pCi} / \mathrm{g}$ and $6 \mathrm{pCi} / \mathrm{g}$ of technetium beta activity, with a maximum concentration of $10.9 \mathrm{pCi} / \mathrm{g}$ (equivalent to just under $0.6 \mathrm{ppb}$ ) in the Little Beaver Creck sunfish discussed above.

PCBs were detected in all but three of 22 fish samples. Average PCB concentrations in the plant outfalls that were sampled, in Little Beaver and Big Run creeks, and in the Scioto River (only one river fish sample was collected) were detectable but less than the EPA food safety standard of 2 parts per ppm PCBs. Four of the individual samples were between 2 and $3 \mathrm{ppm}$ PCBs, and two samples were higher than 3 ppm PCBs. The highest concentration found was 4.0 ppm PCBs. Individual sample results are presented in Part 2.

\subsection{WILDLIFE}

The analysis of wildlife tissues was not a part of the PORTS surveillance program in 1990.

\subsection{VEGETATION}

PORTS has conducted parallel vegetation- and soil-sampling programs since 1975 . Vegetation (wide-blade grass typical of local cattle forage) and soil samples are collected semiannually from several locations in and around the PORTS site. The parallel programs allow the comparison of soil concentrations with vegetative uptake rates. To date, however, both programs have consistently shown only background levels off-site.

\subsubsection{Program Description}

Vegetation samples were collected from 31 off-site locations (see Figs. 6.2 through 6.4); these are divided into three sample groups. Group I includes sample points on or near the DOE Reservation boundary; Group II extends out to $5 \mathrm{~km}$ ( 3 miles) from the site; and Group III extends between 5 and $16 \mathrm{~km}$ ( 3 and 10 miles). Four background locations are located $16 \mathrm{~km}$ (10 miles) from the plant site.

Samples of wide-blade grass are clipped above ground level so that soil is excluded. The sample is placed into resealable plastic bags for transfer to the laboratory. The grass samples are analyzed for uranium, uranium alpha, and technetium beta activity.

The samples also are analyzed for fluoride, which can be taken up from the soil or groundwater or absorbed directly from the air. Some scientists maintain that vegetative uptake of gaseous fluorides is the best indication of undesirable airborne 
concentrations of these compounds. Because the enrichment cascade emits significant quantities of gaseous fluorides, vegetative fluoride concentrations are of great interest to PORTS and its neighbors.

\subsubsection{Program Results}

Vegetation-sampling results for 1990 showed no contamination. Uranium concentrations and technetium beta activity were below detection limits and uranium alpha activity was within normal background ranges in all samples collected.

Fluoride analyses showed a very slight elevation in Group I. Group I results averaged $2.9 \mu \mathrm{g} / \mathrm{g}$ fluorides with a maximum level of $6.4 \mu \mathrm{g} / \mathrm{g}$. Other groups averaged $2.6 \mu \mathrm{g} / \mathrm{g}$. These results are all well under the 30 to $40 \mu \mathrm{g} / \mathrm{g}$ levels at which vegetative fluoride will begin to damage the teeth of foraging cattle. Individual sample resuits are presented in Part 2. 


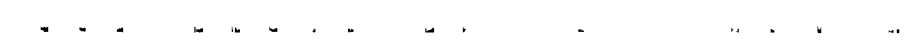




\section{SOIL AND SEDIMENT MONITORING}

Soil and sediment monitoring at PORTS is done to check possible radionuclide accumulation. A summary of the results of each sampling program is presented here, and analytical results of individual samples are presented in Part 2.

In Part 2, the analytical detection limits are disregarded in reporting radioactivity concentrations. This improves the statistical analysis by eliminating the bias introduced by the frequently encountered detection limits, but may mislead or confuse the casual reader with apparent "fals' positives" and negative concentrations.

\subsection{SOIL}

Soil samples are analyzed to determine whether airborne emissions from PORTS are influencing the soil surrounding the site. Samples are collected twice annually from the internal, on-site, off-site, and remote sampling locations shown in Figs. 6.1 through 6.4. PORTS personnel collect collocated soil and vegetation samples in the on-site, off-site, and remote sampling areas to allow correlations to be made between soil and vegetation concentrations.

\subsubsection{Program Description}

A sample of soil is collected from cach sample point and placed into a new container. The container is covered and transported to the laboratory where the sample is dried and ground prior to analysis. Soil samples are analyzed for uranium, uranium alpha activity, and technetium beta activity. They are not analyzed for nonradioactive parameters.

The results are grouped into four sets: internal (within or near the secured plant area), on-site (on or near the DOE property line), off-site (out to $5 \mathrm{~km}$ ), and remote $(5$ to $16 \mathrm{~km}$ ). Four samples from the remote group, taken at the $16-\mathrm{km}$ range, are broken out as background samples. The on-siie, off-sitc, and remote sainples are considered "external" soil samples and are analyzed and reported as a parallel program to the routine vegetation sampling program. These external samples (soil and vegetation) are considered to be representative of natural background concentrations and deposition of airborne radionuclides exclusively. The internal samples also may represent spills (past or present) of radionuclide-bcaring materials, such as decontamination solutions.

External soil samples are considered contaminated if they show more than $10 \mu \mathrm{g} / \mathrm{g}$ uranium, $10 \mathrm{pCi} / \mathrm{g}$ uranium alpha, or $1 \mathrm{pCi} / \mathrm{g}$ technetium beta. The $1 \mathrm{pCi} / \mathrm{g}$ standard for technetium beta activity represents the analytical detection limit rather than a natural concentration. Internal soil samples are allowed $10 \mathrm{pCi} / \mathrm{g}$ technetium beta before being classified as contaminated. Normal area background levels are 3 to $5 \mu \mathrm{g} / \mathrm{g}$ uranium for internal and on-site samples, up to $10 \mu \mathrm{g} / \mathrm{g}$ uranium for the off-site and remote samples, 3 to $6 \mathrm{pCi} / \mathrm{g}$ total alpha, and less than $1 \mathrm{pCi} / \mathrm{g}$ technetium. The higher uranium content of the off-site and remote samples is due to the shale and sandstone formations that crop out around the edges of the DOE reservation. These formations are considerably older, and have a higher natural uranium content, than the clay bed the rescrvation is situated on.

For comparison with the internal contamination standard, $10 \mathrm{pCi} / \mathrm{g}$ of technetium corresponds to $0.6 \mathrm{ppb}$.

\subsubsection{Program Results}

The soil samples showed no significant contamination of the environment.

Of the 32 internal samples, all were within the internal contamination standards (most were within the extcrnal contamination standards) except sample points RIS-19 and RIS-22. These two sample points are adjacent to the X-700 Cleaning Building and the 


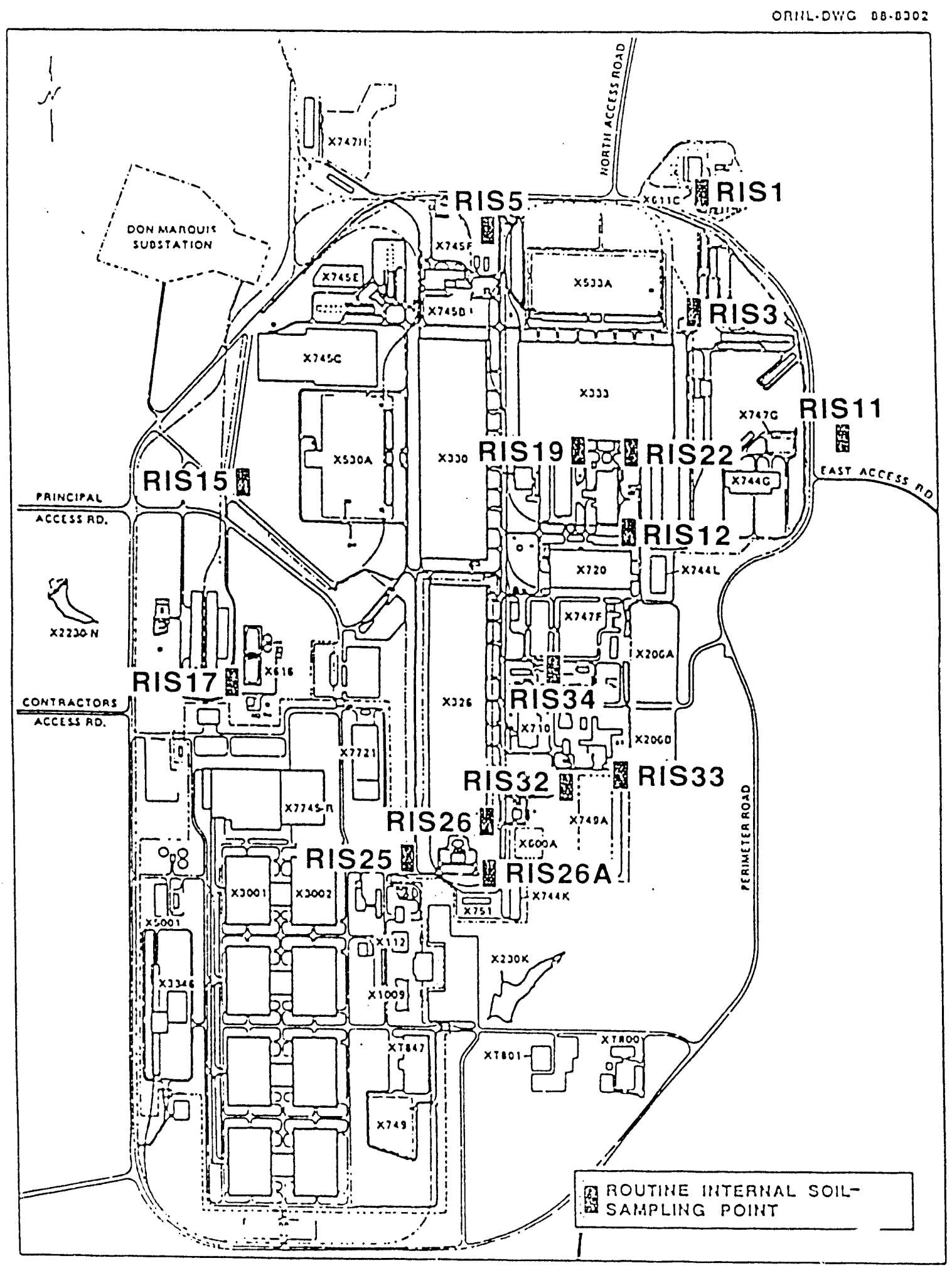

Fig. 6.1. Internal soil-sampling locations at PORTS. 
ORNL-OWG 87-7838R2

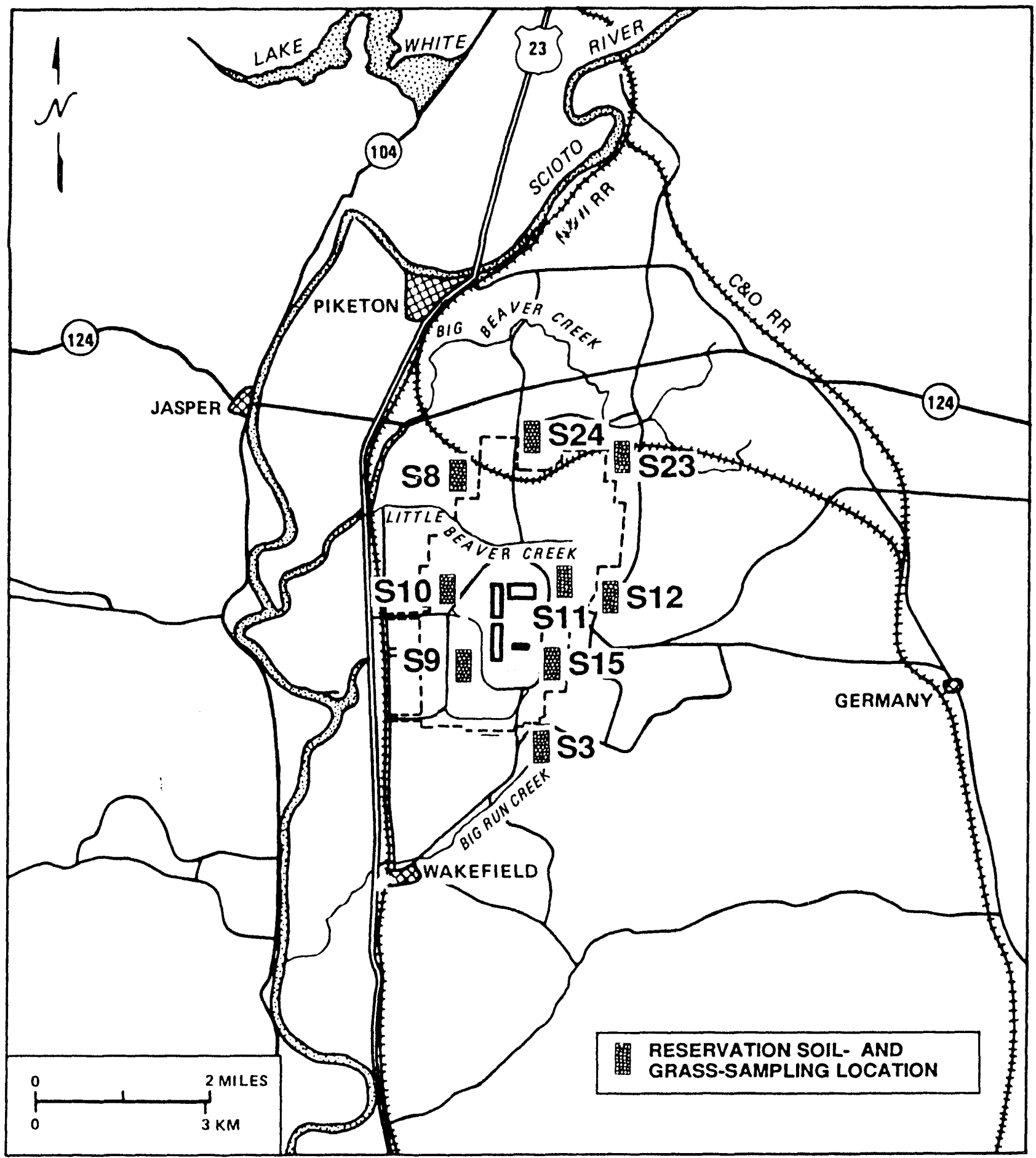

Fig. 6.2. Reservation soil- and vegetable-sampling locations at PORTS. 
ORNL-DWG $8 \%$-7840R2

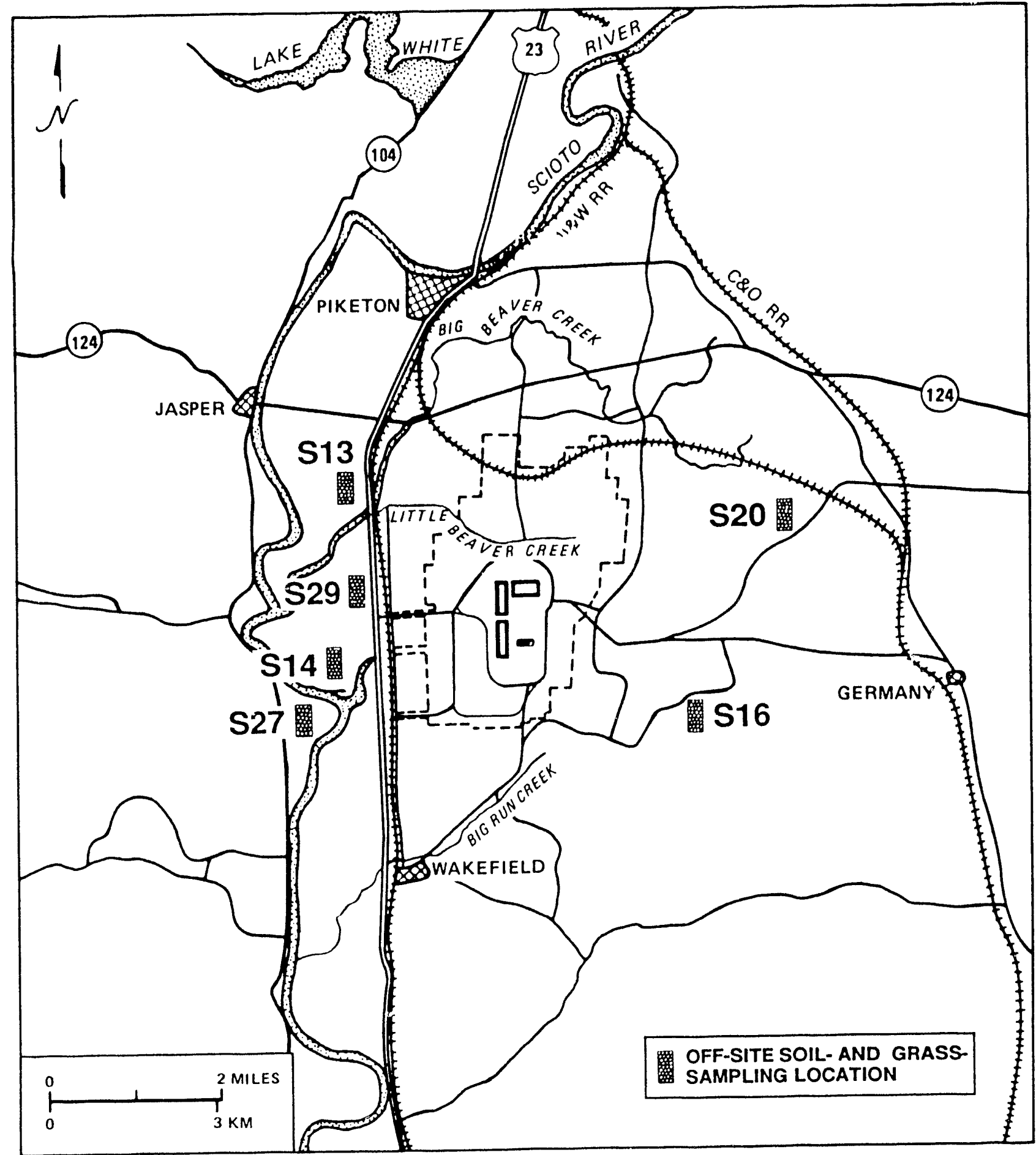

Fig. 6.3. Off-site soil- and vegetable-sampling locations at PORTS. 
ORNL-DWG 87-7634R

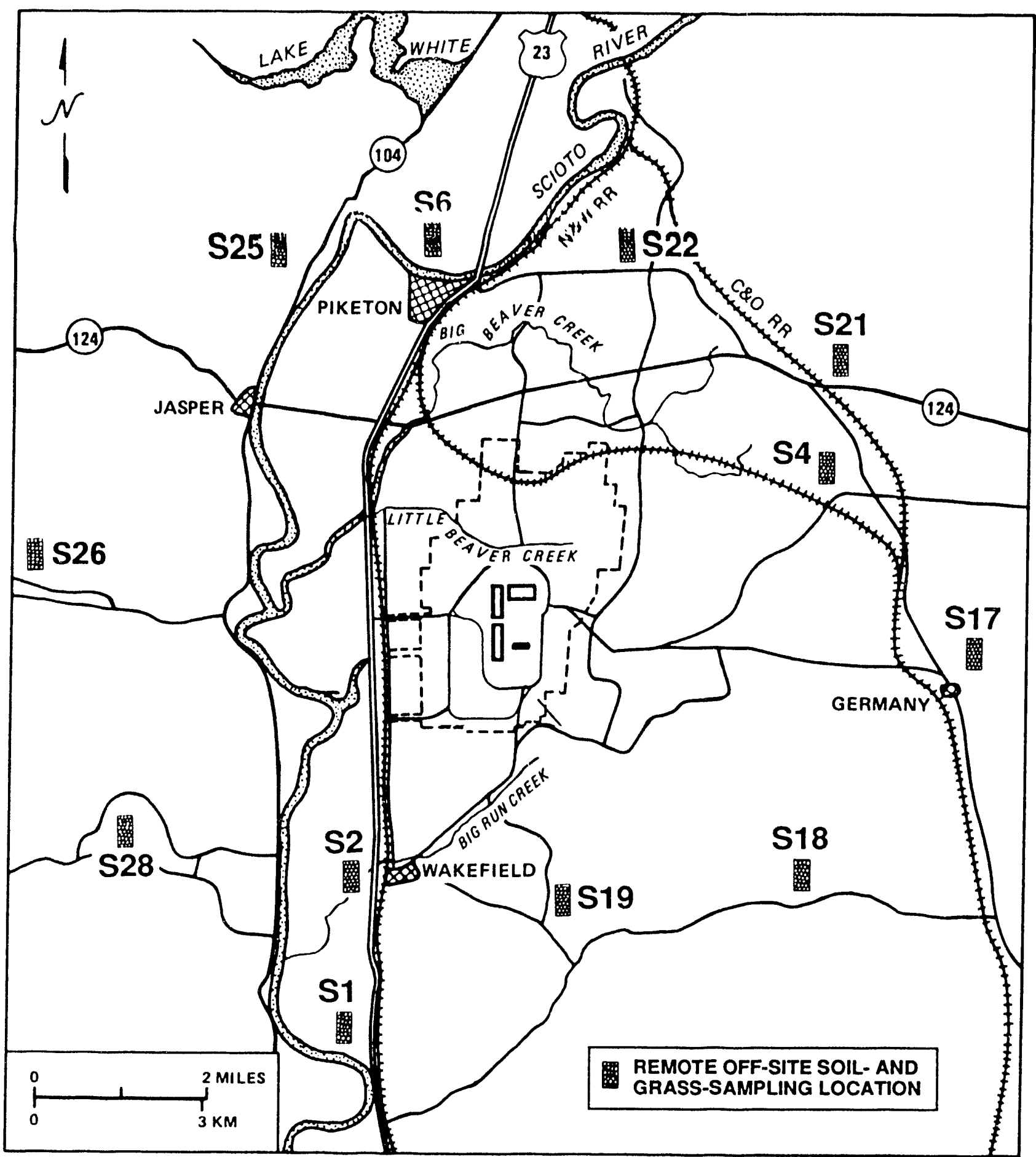

Fig. 6.4. Remote soil- and vegetable-sampling locations at PORTS. 
X-705 Decontamination Building and were already known to be contaminated at low levels. The RIS-19 samples showed up to $100 \mu \mathrm{g} / \mathrm{g}$ of uranium and up to $240 \mathrm{pCi} / \mathrm{g}$ of uranium alpha activity, indicating low enriched uranium, and slightly under $300 \mathrm{pCi} / \mathrm{g}$ of technetium beta activity. The RIS-22 sample showed only slight contamination ( $13 \mathrm{pCi} / \mathrm{g}$ uranium alpha and $21 \mathrm{pCi} / \mathrm{g}$ technetium beta) and only in the fall sample. Both sets of results are consistent with past samples, except that RIS-19 appears more contaminated than in the recent past. This probably reflects the detailed location of the individual samp!es as much as any changes in the actual contamination level.

Analytical results for all 35 external soil sample locations were below contamination levels, except for two locations that showed low levels of technetium contamination. Analytical results from location S13, located west and north of the active plant area and between U.S. Route 23 and the Scioto River (see Fig. 6.3), indicated $4.0 \mathrm{pCi} / \mathrm{g}$ of technetium activity in the spring and $2.0 \mathrm{pCi} / \mathrm{g}$ in the fall of 1990 . Analytical results from the western background location RS10W, located 10 miles to the west of the plant site, indicated $5.0 \mathrm{pCi} / \mathrm{g}$ of technetium in the spring and $2.0 \mathrm{pCi} / \mathrm{g}$ in the fall.

These four results are anomalous in several respects. Most important, vegetation (grass) samples taken at the same locations at the same times did not show any technetium contamination, even though technetium bioaccumulates in plants to a spectacular degree (up to 200-fold under some conditions). Second, no other soil sampling locations, including those between locations S13 and RS 10W and the plant site, show any sign of contamination. Both of these two locations could plausibly be contaminated only via airborne technetium, but if enough airborne technetium had been released to contaminate either of these sites, several other locations, such as S8, S10, S24, and S29, should also show contamination.

Furthermore, prevailing winds at the PORTS site are out of the southwest, and airborne contamination should travel predominantly to the northeast, not to the west where S13 is located, and certainly not to the far west where RS $10 \mathrm{~W}$ is located. The four background locations were, in fact, specifically chosen to be out of reach of any airborne contamination from PORTS. Finally, there are no known sources of even potential technetium emissions large enough to produce measurable concentrations of technetium as far away as S13 and RS10W. Over the last 2 years, technetium emissions and the potential for contamination have significantly decreased at PORTS, due primarily to reduced amounts of technetium in feed material.

In spite of these anomalies, the four results are too consistent to dismiss as simple analytical or sampling errors. The apparent contamination has shown up at the same two locations during two separate sampling events. The most plausible explanation at this point is that some natural beta emitter at these two locations is interfering with the technetium analysis. However, this explanation cannot explain why this hypothetical beta emitter has not been observed before 1990 .

In summary, while there are grounds to suspect that the reported 1990 technetium concentrations for soil sampling locations S13 and RS 10W are biased, the data cannot $\mathfrak{b} \approx$ discarded without investigation. The reported cisncentrations are not dangerous: all soil concentra tions reported are considerably less than natural background levels and are apparently declining, and the "contamination" is not being taken up by the local food chain. Consequently, PORTS plans to give increased priority to revicwing the analytical results from these locations until sufficient data is available to support additional decision making.

\subsection{STREAM SEDIMENTS}

Sediment (mud) samples are collected from local streams and surface waters to determine to what extent dissolved and suspended radionuclides in PORTS' liquid effluents are accumulating in the stream beds surrounding the site (see Fig. 6.5).

\subsubsection{Program Description}

Samples are collected semiannually from the three major drainage ditches (the East and West Drainage ditches and the outfall from the South Holding Pond), the major immediate receiving streams (Little Beaver Creek, Big Beaver Creek, and Big Run Creek), the ultimate receiving stream (the Scioto River), and from four background locations for comparison. All four of the receiving streams are sampled at a location upstream of all plant discharges 
ORNL-DWG 87-10318R2

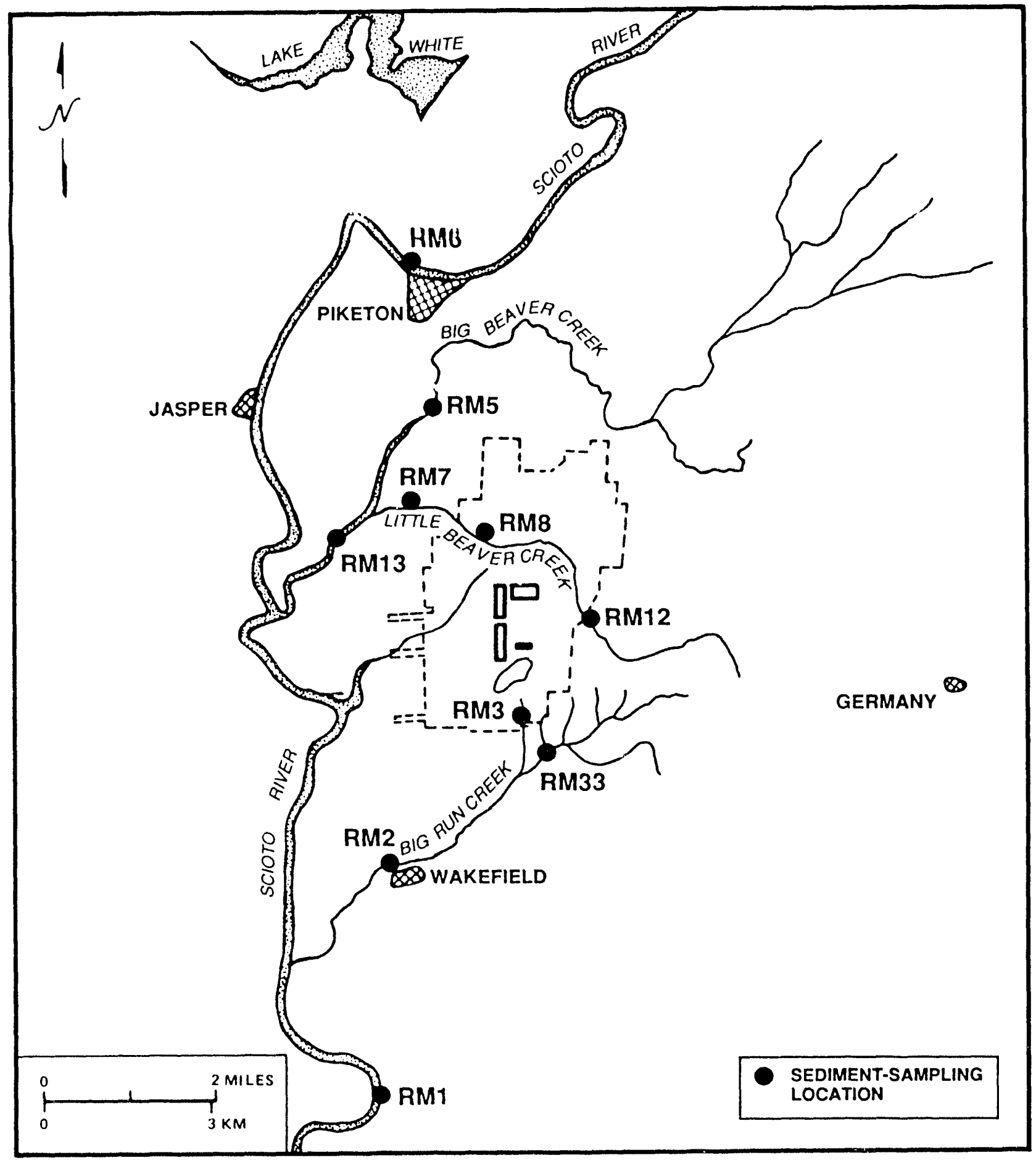

Fig. 6.5. Stream-sediment-sampling locations at PORTS. 
and at least one location downstream of the discharges.

The samples are placed into new sample containers, capped, and transported to the laboratory where they are dried and ground before analysis. Sediment samples are analyzed for uranium, uranium alpha activity, and technetium beta activity. Sediments are not analyzed for nonradioactive parameters.

The sediment contamination standards are the same as those for external soil samples: $10 \mu \mathrm{g} / \mathrm{g}$ uranium, $10 \mathrm{pCi} / \mathrm{g}$ uranium alpha, and $1 \mathrm{pCi} / \mathrm{g}$ technetium beta.

\subsubsection{Program Results}

PORTS historically finds a pattern of minor contamination in the East Drainage Ditch sediments that generally, but not strictly, diminishes with distance downstream along Little Beaver Creek and Big Beaver Creek. The other outfalls and immediate receiving streams typically show little or no sediment contamination, and the Scioto River never shows sediment contamination. The historic contamination in the East Drainage Ditch and its receiving streams stems from the historic discharge of treated process waters through this outfall. This discharge was stopped in accordance with RCRA requirements in November 1988, and sediment contamination along this route has been declining since then.

Radioactive sediment contamination around PORTS is always transient. Transient contamination, as PORTS uses the term, is contamination that is removed quickly by natural processes. Because of this quick and usually continuous removal, transient contamination tends to behave as a slow moving "slug" that continuously travels downstream without any long-term accumulation in any single location.

During 1990, slight to minor sediment contamination was founc' in the East Drainage Ditch and its receiving streams, Little Beaver Creek and Big Beaver Creek. No other sediment contamination was found except for some very slight contamination at one on-site location in Big Run Creek. None of the sediment contamination found in 1990 in any of the streams was high enough to be a threat to human health.

The spring sediment samples showed minor contamination ( $16 \mathrm{ppm} \mathrm{U,} 44 \mathrm{pCi} / \mathrm{g}$ alpha, and $42 \mathrm{pCi} / \mathrm{g}$ technetium) at the East Drainage Ditch outfall and in Little Beaver Creek, with lesser contamination (about $20 \mathrm{pCi} / \mathrm{g}$ technetium only) at and in Big Beaver Creck. The fall sediment samples, on the other hand, showed only slight sediment contamination (14 ppm U, $1.2 \mathrm{pCi} / \mathrm{g}$ technetium, and no alpha contamination) at the outfall; minor contamination in Little Beaver Creek (up to $20 \mathrm{pCi} / \mathrm{g}$ alpha and $17 \mathrm{pCi} / \mathrm{g}$ technetium); and the highest (though still minor) contamination in Big Beaver Creek ( $19 \mathrm{pCi} / \mathrm{g}$ alpha and $34 \mathrm{pCi} / \mathrm{g}$ technetium), illustrating the "slug flow" phenomenon mentioned above.

As expected, neither of the other outfalls showed any sediment contamination of any type, and Big Run Creek showed only very slight contamination at one on-site point; RM3 showed $10.4 \mathrm{pCi} / \mathrm{g}$ alpha and $2 \mathrm{pCi} / \mathrm{g}$ technetium in the fall. The Scioto River showed no contamination of any type and showed essentially the same sediment concentrations both upstream and downstream from the plant. 


\section{POTENTIAL RADIATION AND CHEMICAL DOSE TO THE PUBLIC}

\subsection{RADIATION DOSE}

Small quantities of radionuclides were released to the environment from operations at PORTS during 1990. These releases are quantified and characterized in Sects. 2-6. This section summarizes estimates of the potential consequences of the releases and describes the methods used to make the estimates. Additional information can be found in Part 2 of this report.

\subsubsection{Terminology}

Most consequences associated with radionuclides released to the environment are caused by interactions between radiations emitted by the radionuclides and human tissue. These interactions involve the transfer of energy from the radiations to tissue, a process that may damage the tissue. The radiation may come from radionuclides located outside the body (in or on environmental media or objects) or from radionuclides deposited inside the body (via inhalation, ingestion, and, in a few cases, absorption through the skin). Exposures to radiation from nuclides outside the body are called external exposures; exposures to radiation from nuclides deposited inside the body are called internal exposures. This distinction is important because external exposures occur only as long as a person is near the external radionuclides; simply leaving the area of the source will stop the exposure. Internal exposures will continue as long as the radionuclides remain inside the person.

A number of specialized units have been defined for characterizing exposures to ionizing radiation. Because the damage associated with such exposures results primarily from the deposition of radiant energy in tissue, the units are defined in terms of the amount of incident radiant energy absorbed by tissue and the biological consequences of that absorbed energy. These units include the following.

- Ássorbed dose. A physical quantity that defines the amount of incident radiant energy absorbed per unit mass of an irradiated material; its unit of measure is the $\mathrm{rad}$. The absorbed dose depends on the type and energy of the incident radiation and on the atomic nuniber of the absorbing material.

- Dose equivalent. A quantity that expresses the Jiological effectiveness of an absorbed dose in a specified human organ or tissue; its unit of measure is the rem. The dose equivalent is numerically equal to the absorbed dose multiplied by modifying factors that relate the absorbed dose to biological effects. In this report, as in many others, the term "dose equivalent" often is shortened to "dose."

- Effective dose equivalent (EDE). A risk-equivalent dose equivalent that can be used to estimate health-effects risks to exposed persons. It is a weighted sum of dose equivalents to specified organs. The weighting factors and identification of these specific organs have been published (ICRP 1977; ICRP 1978).

- Committed (effective) dose equivalent. The total (effective) dose equivalent that will be received over a specified time period (i.e., 50 years in this document) because of radionuclides taken into the body during the current year.

- Collective (committed) effective dose equivalent. The sum of (committed) effective dose equivalents to all individuals in an exposed population. The unit of measure is the person-rem.

- Dose conversion factor (DCF). The dose equivalent received from exposure to a unit quantity of a radionuclide via a specific exposure pathway. Two types of DCFs exist. One type gives the committed 
dose equivalent (rem) resulting from intake (via inhalation and ingestion) of a unit activity $(1.0 \mu \mathrm{Ci})$ of a radionuclide. The second type gives the dose equivalent rate (mrem/year) per unit activity $(1.0 \mu \mathrm{Ci})$ of a radionuclide in a unit $\left(\mathrm{cm}^{3}\right.$ or $\left.\mathrm{cm}^{2}\right)$ of an environmental compartment (air or ground surface). DCFs for inhalation and ingestion of radionuclides, for immersion in contaminated air, and for exposure to a contaminated ground surface are listed in Table 7.1 of Part 2 of this report.

\subsubsection{Methods of Evaluation}

\subsubsection{Airborne radionuclides}

Characterization of the radiological consequences of radionuclides released to the atmosphere from PORTS operations during 1990 was accomplished by calculating EDEs to the maximaliy exposed person (a hypothetical individual who is assumed to reside at the most exposed point on (ne plant boundary) and to the entire population ( $-600,300$ persons) residing within $80 \mathrm{~km}$ (50 miles) of the plants. The dose calculations were made using the CAP-88 package of computer codes (Beres 1990), which was developed under sponsorship of EPA for use in demonstrating compliance with NESHAP-Radionuclides (CFR 1989). This package contains the most recent, approved version of the AIRDOS-EPA and DARTAB computer codes and of the ALLRAD88 radionuclide data file. The AIRDOS-EPA computer code implements a steady-state, Gaussian plume, atmospheric dispersion model to calculate concentrations of radionuclides in the air and on the ground; it uses Regulatory Guide 1.109 foodchain models to calculate radionuclide concentrations in foodstuffs (vegetables, meat, and milk) and subsequent intakes by individuals. The concentrations and human intakes are used by EPA's latest version of the DARTAB computer code to calculate EDEs to humans from radionuclides released to the atmosphere. The dose calculations use the DCFs contained in the ALLRAD88 data file (Table 7.1, Part 2).

Radionuclide release data were collected or estimated for three release points. Table 7.2 of Part 2 lists the source parameter values used in the calculations. The radionuclide release inventory is detailed in Sect. 2 and summarized in Table 7.3 of
Part 2, which is a list of the nuclides released, the quantity $(\mathrm{Ci})$ released from each release point, and the particle size (AMAD) and solubility classes used in the calculations.

Meteorological data used in the calculations consisted of joint frequency (STAR) distributions of wind direction, wind speed class, and atmospheric stability categories that were prepared from data collected during 1990 at the PORTS tower. Rainfall during 1990 was $125 \mathrm{~cm}$, the average air temperature was $13^{\circ} \mathrm{C}$, and the average mixing layer height was $2000 \mathrm{~m}$.

The dose calculations assumed that each person remained, unprotected, at home (actually outside the house) during the entire year and obtained food according to the rural pattern defined in the NESHAP background documents (EPA 1989). This pattern specifies that $70 \%$ of the vegetables and produce, $44.2 \%$ of the meat, and $39.9 \%$ of the milk consumed by each person are produced in the local area (e.g., in a home garden). The remaining portion of each food is assumed to be produced within $80 \mathrm{~km}$ (50 miles) of PORTS. Use of this pattern is more conservative than the consumption patterns used in previous annual reports. For collective EDE estimates, production of beef, milk, and crops within $80 \mathrm{~km}$ of PORTS was calculated using the state-specific production values provided with CAP- 88.

Calculated doses from radionuclides released to the atmosphere are summarized in Table 7.4 of Part 2. The hypothetical maximally exposed individual could receive an EDE of 0.06 mrem, which is well below the 10-mrem NESHAP limit and the -300 mrem that the individual actually received from natural sources of radiation. The collective EDE to the entire population around PORTS was $\sim 0.4$ person-rem, which is a minute fraction of the $\sim 180,000$ person-rem that this population received from natural sources of radiation during 1990. The collective EDE to the nearest community was calculated to be $\sim 0.008$ person-rem.

\subsubsection{Waterborne radionuclides}

Water is sampled at all plant outfalls and in the receiving streams. Sample results for the Scioto River show no significant difference in radionuclide concentrations between upstream and downstream locations (see Sect. 3). A hypothetical dose was 
calculated using measured radionuclide discharges from plant outfalls and the average annual flow rate of the Scioto River [i.e., $4.64 \times 10^{12}$ L/year $(1.2 \times$ $10^{12} \mathrm{gal} /$ year) ]. If a person should eat $21 \mathrm{~kg}(46 \mathrm{lb})$ of fish caught in the Scioto River and drink $730 \mathrm{~L}$ (190 gal) of river water during the year, that hypothetical person could receive a 50-year committed EDE of 0.002 mrem (Part 2, Table 7.5). This is a conservative exposure scenario because the river is not used for drinking water downstream of PORTS. About $50 \%$ of the calculated dose from liquid effluents is from drinking water.

\subsubsection{Radionuclides in other environmental media}

The CAP- 88 computer codes calculate doses from ingestion of meat, milk, and vegetables that contain radionuclides that were released to the atmosphere. Using the conservative food consumption pattern described in Subsect. 7.1.2.1, about $58 \%$ of the maximum individual dose and $79 \%$ of the collective dose result from ingestion of foodstuffs.

\subsubsection{Doses to Aquatic Biota}

DOE Crder 5400.5, Chapter II, sets an absorbed dose rate limit of $1 \mathrm{rad} /$ day to native aquatic organisms. To demonstrate compliance with this limit, absorbed dose rates to aquatic invertebrates, fish, and muskrats were calculated by multiplying measured radionuclide concentrations in the Scioto River and internationally recognized, organism-specific dose factors (National Research Council of Canada 1983). Calculated potential dose rates were $0.002 \mathrm{rad} /$ day to invertebrates, 0.0002 $\mathrm{rad} /$ day to fish, and $0.00002 \mathrm{rad} /$ day to muskrats. These results indicate that no aquatic biota should receive an absorbed dose at a rate greater than 1 $\mathrm{rad} / \mathrm{day}$.

\subsubsection{Current Year Summary}

A summary of 1990 maximum doses to an individual is given in Table 7.1. It is unlikely that any one real person could be exposed to maximum doses from both gaseous and liquid effluents because the points of maximum exposure are on opposite sides of the plant. Furthermore, no one is known to draw drinking water from the Scioto River. Nevertheless, the maximum, hypothetical, 50-year committed EDE to an off-site individual from 1990 emissions could be $0.06 \mathrm{mrem}$.

\subsubsection{Findings and Conclusions}

The 50-year committed EDE to the maximally exposed off-site individual from airborne effluents was calculated to be $0.06 \mathrm{mrem}$. This EDE is well within the dose limit $(10 \mathrm{mrem})$ specified in NESHAP for DOE facilities.

The estimated 50-year committed collective EDE to the approximately 600,000 persons living within $80 \mathrm{~km}$ ( 50 miles) of PORTS is 0.4 person-rem for 1990 emissions. This represents about $0.0002 \%$ of the $\sim 180,000$ person-rem the surrounding population would receive from all sources of background radiation. The estimated committed EDE to the population of the nearest community is 0.008 person-rem.

\subsection{CHEMICAL DOSE}

Varying amounts of chemicals were released to the environment from operations at PORTS during 1990. These releases are characterized and quantified in Sect. 3. This section makes estimates of potential human exposure to these chemicals and compares the exposures to acceptable levels of exposure as defined by federal standards and regulations.

Chemicals enter the body by several routes, including inhalation of air and dust, ingestion of food

Table 7.1. Summary of estimated radiation doses to an adult during 1990 at locations of maximum exposure

\begin{tabular}{ccc}
\hline $\begin{array}{c}\text { Emission } \\
\text { pathway }\end{array}$ & Location & $\begin{array}{c}\text { EDE } \\
(\mathrm{mrem})\end{array}$ \\
\hline Gaseous effluents & $\begin{array}{c}\text { Maximally exposed } \\
\text { individual } \\
(1770 \mathrm{~m} \text { ENE) }\end{array}$ & 0.06 \\
Liquid effluents & Scioto River & 0.002 \\
\hline
\end{tabular}


and water, and dermal absorption. A lack of environmental monitoring data precludes an analysis of the inhalation pathway, and members of the public are not expected to have direct dermal contact with soil, water, or sediments on-site. The environmental monitoring data on surface water allow an analysis of the ingestion pathway via drinking water.

\subsubsection{Terminology}

Some of the terms pertinent to understanding discussions of exposure are defined as follows:

- Acceptable daily intake (ADI). Intake of a chemical, measured in $\mathrm{mg} /$ day, that is not anticipated to result in any adverse health effect over a lifetime of exposure. ADIs are calculated from several different federal standards and regulations.

- Calculated daily intake (CDI). Intake of a chemical, expressed in $\mathrm{mg} /$ day, from drinking $2 \mathrm{~L}$ of surface water per day and ingesting fish found in the surface water at the PORTS facility.

- Slope factor $(S F)$. An estimate based on a lifetime probability that a carcinogenic chemical will cause cancer at a dose of $1 \mathrm{mg} / \mathrm{kg} /$ day.

- Maximum contaminant level (MCL). EPA National Interim Primary and National Primary Drinking Water Regulations that apply to all community or public water systems.

- National Pollutant Discharge Elimination System (NPDES). Permit program that includes effluent standards, monitoring requirements, and conditions for discharge.

- Reference dose (RfD). An estimate of the daily exposure to the human population, including sensitive individuals, that is likely to be without an appreciable risk of deleterious effects during a lifetime.

- Secondary maximum contaminant level (SMCL). EPA National Secondary Drinking Water Regulation that applies to public water systems.

\subsubsection{Methods of Evaluation}

\subsubsection{Airborne chemicals}

The release of chemicals into the atmosphere at PORTS is minimized by avoiding unnecessary generation of wastes and by applying effective control technology to meet all permit conditions and DOE requirements. Emission sources may release permitted quantities of chemicals into the atmosphere.

\subsubsection{Waterborne chemicals}

EPA has set daily intake standards for chemicals in the form of oral RfDs and SFs. These values are available from EPA's Integrated Risk Information System (IRIS) (EPA 1991). For noncarcinogenic chemicals, daily exposure to the $R f D$, in $\mathrm{mg} / \mathrm{kg} /$ day, should result in no adv ərse effect over a lifetime. ADIs in $\mathrm{mg} /$ day were calculated from RfDs by multiplying by $70 \mathrm{~kg}$, the average human body weight.

For carcinogens, ADIs were calculated from SFs using the formula:

$$
A D I=\frac{1 \times 10^{-5} \times B W}{S F},
$$

where

$$
\begin{array}{lll}
\mathrm{BW}= & 70 \mathrm{~kg} \\
\mathrm{SF}= & \text { a slope factor of risk per unit dose (ris } \\
\mathrm{mg} / \mathrm{kg} / \text { day). }
\end{array}
$$

A 1 in $100,000\left(10^{-5}\right)$ lifetime risk of developing cancer was used in calculating the ADI.

For chemicals for which RfDs and SFs were not available, national primary and secondary drinking water standards, in $\mathrm{mg} / \mathrm{L}$, were converted to ADI values by multiplying by $2 \mathrm{~L}$, the average daily adult water intake. Drinking water regulations and standards apply to community or public water systems and thus are conservative when applied to surface water.

Table 7.2 lists ADIs for chemicals found in surface water at concentrations above detection limits. For RfDs and SFs, it is assumed that water ingestion is the only pathway of exposure.

Table 7.3 lists CDIs based on concentrations of chemicals above detection limits found at the six NPDES discharges at PORTS. Average values of the sampling data (in $\mathrm{mg} / \mathrm{L}$ ) were multiplied by $2 \mathrm{~L}$ to estimate daily intake levels. The CDIs were compared to the ADIs to establish whether the ingestion of $2 \mathrm{~L}$ of water would result in an exposure above the ADI. 
Table 7.2. ADI for chemicals monitored at the PORTS site-1990

\begin{tabular}{lcl}
\hline \multicolumn{1}{c}{ Chemical } & $\begin{array}{c}\text { ADI } \\
\text { (mg/day) }\end{array}$ & Reference \\
\hline Arsenic & 0.07 & RID \\
Chromium & 0.35 & RfD \\
Copper & 2.6 & MCL \\
Iron & 0.6 & SMCL \\
Nickel & 1.4 & RID \\
Trichioroethylene & 0.06 & SF \\
Zinc & 14 & RrD \\
\hline
\end{tabular}

CDI/ADI ratios of $<1$ indicate an acceptable level of risk, whereas CDI/ADI ratios $>1$ indicate an unacceptabie risk or the need for further study.

Sampling data for six inorganic chemicals and one organic chemical, trichloroethylene (TCE), were available for the six NPDES stations. All CDI/ADI ratios were $<1$ except several ratios for iron and one for total chromium. Iron is an essential trace element and is only slightly toxic at high concentrations. According tc EPA (1989), such chemicals can be excluded from risk assessments. In addition to total chromium (valance states +3 and +6 ), the more toxic chromium $^{+6}$, on which the RfD is basid, was analyzed separately at NPDES 004 . When only chromium $^{+6}$ is measured the CDI/ADI ratio is $<1$, and chromium warrants no further investigation. TCE, the only organic chemical monitored, was absent from most samples; when maximum values were considered, there was still no risk from ingestion.

Outfalls are generally located within areas of DCE facilities that are not readily accessible to the general public. Thus consumption of $\dot{i}$ ater from outfalls is unlikely. Furthermore, as the pollutant moves downstream from the out fall and the volume of water increases, the concentration of the pollutant discharged from the outfall decreases.

\subsubsection{Chemicals in other environmental media}

An important pathway for human exposure to chemicals is atmospheric deposition onto vegetation and subsequent transfer into beef and milk. Direct measurements for concentrations of chemicals in vcgetation, beef, or milk in the vicinity of the PORTS facility have not been made.

\subsubsection{Direct exposure}

Direct exposure to chemicals does not represent a likely pathway of exposure at the PORTS facility. For airborne releases, concentrations off-site are too small to present problems through the dermal exposure pathway. For aquatic releases, nutfalls are generally located within areas of the DOE facility that are not readily accessible to the general public. Although exposures for consumption of drinking water at the discharge sites were calculated, public consumption of water from the area of the discharge is highly unlikely.

\subsubsection{Current year summary}

Additional information is needed on routes of exposure other than surface water to achieve a more complete che:nical exposure analysis. In the 1990 analysis of exposure to waterborne inorganic chemicals, the CDI/ADI ratios were $<1$, indicating that for drinking water, concentrations did not exceed acceptable daily intake levels. Persons off-site would be exposed to lower concentrations due to stream dilution. The inorganic and organic chemicals monitored at NPDES sitcs at POKTS pose no risk to the public. 
Table 7.3. Potential chemical dose/ADI comparisons for surface waters at the PORTS site during 1990

\begin{tabular}{|c|c|c|c|}
\hline Chemical & $\begin{array}{c}\mathrm{CDI}^{a} \\
\text { (mg/day) }\end{array}$ & $\begin{array}{c}\text { ADI } \\
\text { (mg/day) }\end{array}$ & CDI/ADI \\
\hline \multicolumn{4}{|c|}{ NPDES 002} \\
\hline $\begin{array}{l}\text { Arsenic } \\
\text { Copper } \\
\text { Imn } \\
\text { Manganese } \\
\text { Nickel } \\
\text { Zinc }\end{array}$ & $\begin{array}{l}0.005 \\
0.0058 \\
2.092 \\
0.842 \\
0.008 \\
0.105\end{array}$ & $\begin{array}{l}0.07 \\
2.6 \\
0.6 \\
7.0 \\
1.4 \\
14\end{array}$ & $\begin{array}{l}0.071 \\
0.002 \\
3.49 \\
0.120 \\
0.006 \\
0.007\end{array}$ \\
\hline \multicolumn{4}{|c|}{ NPDES 602} \\
\hline $\begin{array}{l}\text { Arsenic } \\
\text { Copper } \\
\text { Iron } \\
\text { Manganese } \\
\text { Nickel } \\
\text { Zinc }\end{array}$ & $\begin{array}{l}0.0008 \\
0.012 \\
1.83 \\
0.193 \\
0.065 \\
0.214\end{array}$ & $\begin{array}{l}0.07 \\
2.6 \\
0.6 \\
7.0 \\
1.4 \\
14\end{array}$ & $\begin{array}{l}0.011 \\
0.004 \\
3.05 \\
0.028 \\
0.046 \\
0.015\end{array}$ \\
\hline \multicolumn{4}{|c|}{ NPDES 003} \\
\hline Nickel & 0.015 & 1.4 & 0.010 \\
\hline \multicolumn{4}{|c|}{ NPDES 604} \\
\hline $\begin{array}{l}\text { Copper } \\
\text { Iron } \\
\text { Nickel } \\
\text { Zinc }\end{array}$ & $\begin{array}{l}0.023 \\
0.976 \\
0.053 \\
0.262\end{array}$ & $\begin{array}{l}2.6 \\
0.6 \\
1.4 \\
14\end{array}$ & $\begin{array}{l}0.009 \\
1.627 \\
0.038 \\
0.019\end{array}$ \\
\hline \multicolumn{4}{|c|}{ NPDES 004} \\
\hline $\begin{array}{l}\text { Chromium (total) } \\
\text { Chromium }^{+6} \\
\text { Copper } \\
\text { Iron } \\
\text { Zinc } \\
\text { Trichloroethylene }\end{array}$ & $\begin{array}{l}0.801 \\
0.0002 \\
0.006 \\
0.065 \\
0.147 \\
0.002^{b}\end{array}$ & $\begin{array}{c}0.35 \\
0.35 \\
2.6 \\
0.6 \\
14 \\
0.06\end{array}$ & $\begin{array}{l}2.289 \\
0.0006 \\
0.002 \\
0.108 \\
0.010 \\
0.033\end{array}$ \\
\hline \multicolumn{4}{|c|}{ NPDES 605} \\
\hline $\begin{array}{l}\text { Chromium } \\
\text { Copper } \\
\text { Iron } \\
\text { Nickel } \\
\text { Zinc } \\
\text { Trichloroethylene }\end{array}$ & $\begin{array}{l}0.007 \\
0.187 \\
0.356 \\
0.366 \\
0.067 \\
0.002^{b}\end{array}$ & $\begin{array}{l}0.35 \\
2.6 \\
0.6 \\
1.4 \\
14 \\
0.06\end{array}$ & $\begin{array}{l}0.021 \\
0.072 \\
0.593 \\
0.261 \\
0.005 \\
0.033\end{array}$ \\
\hline
\end{tabular}

a $\mathrm{B}$ ased on annual average sampling values.

bMaximum amount detected. 


\section{SOLID WASTE MANAGEMEN' $\Gamma$}

\subsection{DESCRIPTION}

\subsubsection{Purpose}

PORTS has developed an extensive solid waste program to ensure compliance with applicable state and federal regulations. Under these regulations a solid waste is defined to include any solid, liquid, semisolid, or contained gas that is discarded. Therefore, the solid waste program at PORTS includes contained gaseous wastes and liquid wastes that are not regulated under Ohio NPDES regulations.

The policy of the PORTS waste management program is that the protection of employees, the public, and the environment is the primary objective of waste management practices. To comply with this policy, equipment, practices, and procedures must be continually improved.

The PORTS waste management prograra is designed to provide a "cradle-to-grave" system that supplies management services for all types of wastes from the point of generation through ultimate disposal. The system ensures that all wastes are managed in accordance with all state and federal regulations and accepted industry practices. Waste minimization is an integral part of the waste management program and includes efforts to minimize waste generation and to reduce the toxicity of the wastes that are generated.

\subsubsection{Environmental Regulatory Review}

\subsubsection{Orders and regulations governing radioactive wastes}

Management of radioactive wastes and radioactively contaminated facilities is governed by DOE Order 5820.2A and the Atomic Energy Act of 1954 as amended. These regulations provide guidelines for characterization, storage, and disposal of all categories of radioactive wastes. Radioactive wastes that also contain RCRA hazardous wastes are subject to RCRA requirements in addition to radioactive waste requirements.

\subsubsection{Orders governing classified wastes}

Portions of the materials, equipment, and information at the PORTS facility are classified for security reasons by the U.S. government. DOE Order 5632.1 prescribes DOE requirements for the physical protection of classified material.

\subsubsection{Orders and regulations governing hazardous wastes}

Hazardous waste regulations at PORTS include RCRA of 1976 and the Ohio Hazardous Waste Rules. Additionally, DOE Order 5480.4 requires that hazardous waste generated by DOE-funded activities be managed in an environmentally acceptable manner. The Atomic Energy Act of 1954 as amended establishes the regulations governing processing and use of source, by-product, and special nuclear materials. The provisions of the Atomic Energy Act, as well as RCRA, are applied to those wastes that are hazardous and radioactive (i.e., mixed wastes).

RCRA of 1976 and the Hazardous and Solid Waste Amendments of 1984 regulate the generation, transportation, treatment, and disposal of hazardous wastes. RCRA establishes the following PORTS requirements:

- standards for hazardous waste identification

- standards for the operation and management of hazardous waste treatment, storage, and disposal facilitics;

- requirements for obtaining permits for treatment, storage, or disposal of hazardous wastes;

- inspections; 
- federal enforcement; and

- hazardous waste site inventory.

The Hazardous and Solid Waste Amendments of 1984 reauthorize and expand RCRA to include land disposal criteria for hazardous wastes, new analytical testing requirements, and corrective action critcria for solid waste management units.

\subsubsection{Regulations governing conventional waste}

Regulations promulgated under the Solid Waste Disposal Act and the Ohio Solid Waste Disposal Act and codified in OAC-3745-27 and -37 govern the planning, design, construction, operation, and maintenance of solid waste processing and disposal facilities. Domestic sewage and industrial wastewater flows that are subject to NPDES permits are excluded. Waste materials such as RCRA wastes, PCB wastes, asbestos, and other specified wastes cannot be disposed of in a conventional disposal or treatment facility unless granted a variance under this act. Prior to construction or modification of a treatment or disposal facility, detailed design drawings, specifications, operating plans, and closure plans must be approved by Ohio and must comply with the requirements of the National Environmental Policy Act (NEPA). Operating records, future plans, and capacities also must be reported to the Ohio Environmental Protestion Agency (OEPA).

\subsubsection{Compliance Activities}

Hazardous waste facilities at PORTS are operated in accordance with the interim status standards stated in 40 CFR 265 and Ohio Administrative Code (OAC) 3745-50 to -69. The Part A Permit application, originally submitted in April 1984, is updated as hazardous waste management needs dictate or as the regulations change. The latest revision, submitted in September 1990, included additional wastes identified as hazardous by the newly effective Toxicity Characteristic listing.

Closure plans have been submitted to OEPA and EPA for the X-616 and X-701B surface impoundments, the X-231B oil biodegradation plot, and the X-749 contaminated materials disposal facility. OEPA approved the closure plans in July 1989. At the X-701B facility, waste removal began in December 1989 and was completed in early 1990.

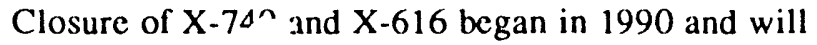
be completed in 1791 . An interim cap has been installed at X-231B, and final closure options continue to be evaluated.

The PORTS Part B Permit application was being revised at the end of 1990 for January 1991 submission. Facilities included in this revision will be the existing X-326, X-744GU unrestricted access, $X-744 G R$ restricted access, and $X-752$ storage units, and the proposed new X-744H, XT-847, and X-3346 storage units. Post-Closure Care Permits are included for X-231B, X-749, and X-701B. Until a full permit is issued, PORTS will continue to operate according to interim status standards.

The latest hazardous waste inspection was performed by OEPA in September 1990. A notice of violation was received indicating the following deficiencies: (1) operation of hazardous waste facilities without a permit (Part A was submitted after April 9, 1981); (2) lack of waste evaluations; (3) violation of accumulation time limits; (4) deficiencies in waste storage and container inspection; (5) inadequacy of waste storage facility maintenance; (6) deficiency in aisle space; (7) inadequate distribution of Contingency Plan copies; (8) incomplete record-keeping; (9) lack of a closure plan, tank assessment, containment and detection systems, tank spill and overflow control, and tank inspections for the X-700 chromic acid tank; and (10) leaking containers and deficiencies in container management. PORTS responded to all the deficiencies and provided additional information to OEPA on 10/26, $12 / 7$, and $12 / 21 / 90$ as data became available. In addition, PORTS strengthened waste management programs by implementing stronger internal inspection, record-keeping, and audit systems and by adding a new Waste Management Division to focus attention on the waste issues. Facility maintenance problems were corrected, and contingency plans were distributed. A closure plan was submitted to OEPA and a tank assessment was performed for the X-700 chromic acid tank. Container leaks were stopped, and a quality assurance team continues to investigate the problcm of leaking containers.

The X-735 sanitary landfill is the only permitted solid waste facility at PORTS. A license to operate the landfill is obtained from Pike County annually. Wastes permitted in the X-735 landfill include cafeteria wastes, industrial wastes, disinfected 
medical wastes (except drugs), construction/ demolition debris, and, in designated locations, asbestos. No hazardous wastes, Toxic Substances Control Act (TSCA) wastes, or radioactive wastes are permitted in this facility.

The PORTS construction spoils area, located immediately west of the X-735 sanitary landfill, is an operating landfill for materials not regulated as solid wastes by Ohio. Materials of this type include construction and demolition debris and wastes from brush and tree clearing operations.

\subsubsection{Program Strategy}

The goals of PORTS solid waste management are (1) to ensure compliance with all federal, state, and local regulations; (2) to minimize the volume and hazard of all hazardous and radioactive wastes produced; (3) to protect the environment from unintentional releases of hazardous or radioactive materials; (4) to protect personnel from hazards associated with handling solid wastes; and (5) to minimize the long-term risks and liability from waste disposal. These goals are implemented through the combined efforts of PORTS operations and maintenance personnel with coordination, strategy, technology, and regulatory interpretation provided by the Environmental Control Department and the newly formed Waste Management Division. Compliance assurance is provided by employee training and by periodic inspections and audits performed by departmental supervision and by personnel from Waste Management and Environmental Control.

Long-range planning, new technology investigation, and new program strategies for waste management are developed by PORTS Waste Management in cooperation with other Oak Ridge Operations personnel and facilities. Waste minimization strategy includes five current options:

- segregation,

- material substitution,

- process changes,

- mechanical compression volume reduction, and

- recycling/reuse.

Environmental protection is provided through the use of Department of Transportation (DOT) specification packaging and by storage in properly engineered and permitted facilities. An extensive monitoring and surveillance program monitors NPDES discharges and checks for unintentional releases. Personnel protection is provided through standard industrial protective equipment applied in accordance with requirements determined from Material Safety Data Sheets and Industrial Hygiene/Health Physics recommendations. Long-term risks and liabilities for disposals are minimized by destroying or removing the hazardous constituent whenever possible, as opposed to burial or storage.

\subsection{WASTE GENERATION}

\subsubsection{Types of Waste Generated}

PORTS solid waste is managed in five different categories determined by the regulatory requirements for solid wastes. The first category, radioactive waste, does not contain materials regulated by RCRA or TSCA. These are low-level radioactively contaminated wastes. Subsect. 8.3.1.1 describes the wastes in this category and the measures used to manage them. The second category, classified wastes, consists of discarded articles that reveal classified information. Subsect. 8.3.1.2 discusses classified waste management. The third category is hazardous wastes as defined by RCRA. Since June 1987, radioactive wastes that also contain RCRA hazardous wastes are subject to RCRA requirements in addition to radioactive waste requirements. Subsect. 8.3.1.3 describes the hazardous waste characterization process and management programs.

TSCA wastes include PCBs and asbestos. PCBs are used as a dielectric fluid in PORTS electrical equipment, are present as a contaminant in some waste materials, and are an original component in the gasket material in ventilation ducts. Asbestos materials are used as insulation on water and steam lines and other heat-related processes. Subect. 8.3.1.4 discusses the waste management programs for these wastes.

Conventional solid waste is the fifth and final category of PORTS solid waste. The PORTS sanitary landfill, X-735, is the principa means of sanitary waste disposal. Asbestos waste is managed as a special subcategory of sanitary waste. Conventional solid wastes, disinfected wastes, construction spoils, and fly ash are included in this waste category (see 
Subect. 8.3.1.5). PORTS' waste generation data for 1989 are given in Table 8.1 of Part 2 of this report.

\subsubsection{Waste-Generating Activities}

\subsubsection{Radioactive wastes}

Scrap metal and other nonburnable waste generated as a result of modifying or replacing equipment may be radioactively contaminated, depending upon how the equipment was used or where the maintenance work took place. Nonradioactive wastes are carefully segregated to minimize the total volume of radioactive wastes. Other radioactive wastes that do not contain hazardous constituents are generated by the various processes used to enrich uranium, by the trapping media used by the gaseous diffusion industry, and by decontamination of radioactively contaminated equipment.

\subsubsection{Classified wastes}

Classified wastes are generated because of classification of the equipment and materials used in the gaseous diffusion plant. This category also includes magnetic media (e.g., computer disks and tapes) and classified documents requiring disposal.

\subsubsection{Hazardous wastes}

Hazardous wastes are generated on the plant site during various cleaning and degreasing operations, as well as during the required analytical work done by the laboratory. Hazardous wastes contaminated with uranium typically are generated as a result of degreasing and cleaning components that are contaminated with uranium or from treating the uranium recovery system, which generates a sludge that is characteristically hazardous because of leachable cadmium and lead.

\subsubsection{TSCA wastes}

PCB wastes of greater than $500 \mathrm{ppm}$ typically are generated as a direct result of work with the electrical switch gear. PCR wastes of less than $500 \mathrm{ppm}$ are a direct result of replacing oils in some of the small equipment or lubricating-oil spills and leaks in the systems contaminated with PCBs. PCB wastes contaminated with uranium typically are generated as a result of the process building floor sweeping and the amelioration of leaks of electrical equipment in the process buildings. Asbestos wastes are generated as a result of removing asbestos insulation from water and steam lines and other heat-related processes throughout the plant site.

\subsubsection{Conventional solid wastes}

Conventional solid waste consists of normal industrial wastes that contain no radioactive, hazardous, or toxic constituents. These wastes are regulated by the Ohio Solid Waste Act or are specifically exempted by the act. Typical examples of regulated wastes are industrial waste, sanitary waste, and sterilized medical and infectious waste. Examples of nonregulated wastes are fly ash and construction spoils. Fly ash waste is generated by burning coal for heating and process needs. Sanitary and industrial wastes are generated by the administrative duties, cafeteria, and similar activities on the plant site.

Sterilized medical and infectious wastes are generated at the medical facility in small quantities.

Construction spoils are a direct result of the ongoing construction activities on the plant site.

\subsection{WASTE MANAGEMENT ACTIVITIES}

\subsubsection{Waste Management System}

\subsubsection{Low-level radioactive waste management program}

DOE Order 5820.2A addresses the management of radioactive wastes and radioactively contaminated surplus farilities. Disposal site requirements include site selection, design, operation, waste acceptance, closure, and postclosure. Each year, production activities at PORTS generate tons of nonhazardous solid waste contaminated by low levels of radioactivity. Disposal of low-level radioactive solid wastes has been by shallow land burial at the X-749 contaminated materials burial facility. Operations at this facility ceased in May 1990. Closure of X-749, mandated by OEPA, began in FY 1990. A new disposal facility is planned for operation in FY 1996 that will meet established criteria from EPA and DOE and will incorporate the latest strategy for disposal of low-level radioactive waste. 
PORTS has been placing radioactive wastes not disposed of in the X-749 facility into canisters constructed from excess converter shells and into carbon steel boxes that are approximately $3 \mathrm{yd}^{3}$ in volume. These canisters are made of nickel-lined steel with steel tops and bottoms welded to the shell. I-beams are welded to the bottom of the canisters to brace them and to allow movement by a forklift. Contaminated burnable materials (formerly incinerated on-site) and contaminated nonburnable scrap are placed in these steel boxes. The boxes of burnable waste will be stored until the new disposal facility or incinerator becomes operational. All materials in canisters or strong, tight containers are placed in indefinite storage pending final disposition.

\subsubsection{Classified waste management program}

Portions of the materials, equipment, and information at the POR TS facility are classified for security reasons by the U.S. government. DOE Order 5632.1 prescribes DOE requirements for the physical protection of classified material. The Atomic Energy Act has provisions for protection of classified nuclear materials. Classified wastes are stored on-site in secure storage areas or disposed of by shallow land burial if appropriate.

\subsubsection{Hazardous waste management program}

Hazardous wastes (as defined by RCRA) contain constituents that are described by one or more of the following four categories:

- The waste possesses one of the following characteristic hazards: toxicity, ignitability, corrosivity, reactivity, or toxicity characteristic (TC) leachable materials (i.e., leachable concentrations of $\mathrm{Ag}, \mathrm{As}, \mathrm{Ba}, \mathrm{Cd}, \mathrm{Cr}, \mathrm{Pb}, \mathrm{Hg}, \mathrm{Se}$, certain pesticides, or certain organic chemical compounds exceeding specified threshold values).

- The waste is generated from a nonspecific listed source or process (e.g., spent halogenated solvents or wastewater treatment sludges from electroplating operations).

- The waste is generated from a specific listed source. PORTS does not use any specific listed processes and thus does not have any wastes characterized as hazardous by this criterion.
- The waste contains specifically listed, discarded, commercial chemical products.

A waste is a mixed waste if it is a listed hazardous waste or possesses a hazardous characteristic and is contaminated with radioactive materials. A waste mixture of nonhazardous material with listed hazardous waste becomes a hazardous waste regardless of the relative amounts of each material in the mixture.

Waste solvents: All waste solvents, flammable and nonflammable, are stored in containers meeting DOT specifications. The waste solvents are stored in the X-752 warehouse, which has interim status as a RCRA storage facility. The facility is locked except when in use.

Lab packs and waste chemicals: Small quantities of miscellaneous waste chemicals are stored in hazardous material storage lockers in the X-710 laboratory facility, or they are packaged in small quantities with inert absorbent in 20-gal lab pack containers and DOT Specification $17 \mathrm{C}$ drums and stored in the X-752 hazardous waste storage facility. Small quantities of nonradioactive miscellaneous waste chemicals are stored in several hazardous material storage lockers at various storage locations in the X-710 laboratory facility and await disposal. Separate unit price contracts also are planned to allow disposal of hazardous waste chemicals approximately as generated; shipments are projected every 90 days.

Sludges: Some sludges resulting from the treatment of process wastes are listed or are characteristically hazardous as well as radioactive. Storage is, and will continue to be, needed for these sludges. Management of sludges may include treatment, delisting, and stabilization. Treatment of chromium sludges from the X-616 chromium sludge surface impoundments has been performed as part of the closure activities with the approval of OEPA and EPA. The treatment immobilizes the chromium, which would otherwise be leachable above the specified limits. After treatment, the waste is managed as a nonhazardous waste and disposed of in the X-735 Sanitary Landfill. The solvent-contaminated mixed waste sludge was removed from the $X-701 B$ Holding Pond, dewatered, and placed into storage in the $\mathrm{X}-744 \mathrm{G}$ Building. Commercial waste incinerators are used to the extent possible to treat and fispose of PORTS nonradioactive listed sludges. 
PORTS generates a radioactive waste, "heavy metal sludge," that has been found to be hazardous because of leachable cadmium and occasionally lead exceeding the specified limits. Plans are to immobilize the toxic metals by encapsulation. The process has not been selected at this time.

Corrosive wastes: Acid and caustic wastes are generated from plating, cleaning, and laboratory operations. These wastes may either be treated on-site or disposed of commercially. The microfiltration unit in the X-705 Decontamination Building can be used to treat certain hazardous wastewaters. Sludges resulting from treatment are managed as previously described. Certain corrosive wastes may be stored in the X-752 hazardous waste storage facility before shipment off-site.

Ignitable wastes: Ignitable wastes generated at PORTS include nonchlorinated solvents and waste fuels. Solvents are stored in drums within the X-752 hazardous waste storage facility. This storage complies with environmental regulations and provides waste segregation of incompatible materials.

Reactive wastes: Reactive wastes have one or more of the following properties: they are unstable; they react with water either violently or to form explosive or toxic gases; or they can be readily detonated. Spent cyanide-bearing solutions and laboratory chemicals comprise most of the reactive wastes generated at PORTS. Interim storage is provided by the $\mathrm{X}-752$ hazardous waste storage facility or, for small-quantity lab chemicals, by hazardous material lockers in X-710.

Extraction procedure $(E P)$ toxic wastes and Toxicity Characteristic Leaching Procedure (TCLP) wastes: Solid wastes contain certain metals or pesticides that will leach out in concentrations above specified limits. Wastewater treatment sludges at PORTS have been found to contain toxic levels of metals. At the X-616 chromium sludge lagoons, chromium is the toxic constituent; whereas leachable cadmium and occasionally lead are in sludges produced by the X-705 heavy metals treatment process and the $X-705$ microfiltration process. The new TCLP became effective during 1990 and now is used for waste characterization, replacing the EP toxicity test.

Delisting: Delisting allows for exempting RCRA-listed wastes from further regulation under RCRA. Comprehensive lab analysis and documentation must be provided to prove that the waste no longer meets the criteria for which it was listed and that any hazardous constituent potentially present does not pose a threat to the environment. Delisting is required after treatment for any waste that contained a listed hazardous constituent. After delisting, the waste generally can be managed as a nonhazardous waste.

Disposal: Commercial waste incinerators are used to the extent possible to destroy and dispose of PORTS nonradioactive hazardous materials that are amenable to this type of treatment. Regardless of the disposal method, all applicable land disposal restriction (LDR) criteria are followed. No existing commerciai sites are licensed to manage hazardous waste that is also radioactive. PORTS generates large quantities of hazardous sludges that are also radioactive as a result of wastewater treatment facilities and remedial action programs. Plans are to ship these sludges for removal of the listed constituent by incineration in an incinerator located at the K-25 Site in Oak Ridge, Tennessee. The incinerator underwent startup testing during 1988 and 1989 and will begin productive operation during 1991. The incinerator has been designed to destructively incinerate most listed organic materials as well as PCBs, and it will be capable of processing radioactive materials. However, an approximate 15-year backlog of this type of material has been identified for this incinerator, so considerable storage capacity will still be required.

\subsubsection{Wastes governed by TSCA}

PCBs are regulated by TSCA. The primary sources of PCBs at PORTS are dielectric fluids used in electrical equipment. Ventilation duct gaskets also have been PCB-impregnated during installation to enhance pliability and sealing properties. Contamination from these sources has spread during past operations to include lube and hydraulic oils, solvents, and floor sweepings. Steps have been taken to prevent further cross-contamination; however, several lube oil systems had become contaminated in excess of $50 \mathrm{ppm}$ PCB. All PCB transformers at PORTS are diked. Nonradioactive PCB materials are shipped off-site for destructive incineration. Radioactive PCB materials are being stored and will be incinerated at the K-25 Site TSCA incinerator in the future. However, long-term storage is required 
because at least a 5-year backlog of solids and a 2 -year backlog of liquids has accrued for the incinerator.

$P C B$ transformers: PORTS has 161 transformers in service that are filled with PCBs. These transformers are located throughout the plant, mostly within the three process buildings. Current regulations allow the continued operation in industrial service of any transformer containing PCBs as long as that use does not pose any risk of contamination to the food chain. PORTS plans to continue to use these PCB transformers. Dikes and concrete pads prevent inadvertent release of the transformer oils to the environment in case a failure of the casing occurs.

$P C B$-contaminated waste oils, solvents, and solids: Liquid and solid $\mathrm{PCB}$ wastes are stored in drums at PORTS. PCB-contaminated solids (e.g., soil, sludge, floor sweepings, rags, paper, etc.) are stored in DOT specification drums in the X-333, $X-330$, and $X-326$ process buildings and in the $X-334$ PCB transfer building. For those wastes that are not radioactive, off-site treatment using incineration for PCB destruction is arranged with a commercial disposal facility. To manage these wastes, the TSCA incinerator has been constructed at the K-25 Site. This facility will incinerate PCB and other hazardous organic wastes that also may be radioactive. It will receive wastes from all Oak Ridge Operations facilities including PORTS.

A dedicated bulk liquid trailer and a dedicated cargo van trailer are available for transport of materials. Each trailer has been equipped with antileak and leak detection devices. Shipping facilities are responsible for proper packaging and manifesting wastes. Tractors and drivers are also the responsibility of the shipping facility. Environmental permits for incineration of TSCA and RCRA wastes have been requested, and trial burns as required by the RCRA Part B Permit are imminent. The facility has $340,000 \mathrm{~L}$ of liquid storage capacity and segregation capability for PCB and non-PCB wastes. Ash is continuously discharged from the incinerator to a quench-water pit and conveyed from the pit to drums for storage. Ash will be analyzed, delisted if possible, stabilized if necessary, and stored. Plans call for returning the ash to the generator for disposal.

\subsubsection{Conventional solid waste management program}

Ohio Solid Waste Disposal Act: The Ohio Solid Waste Disposal Act and associated promulgated regulations govern the planning, design, construction, operation, and maintenance of solid waste-processing and disposal facilities. Solid wastes are defined by this act as any garbage, refuse, or sludge from water and wastewater treatments or air pollution control, and any other discarded material including solid, liquid, semisolid, or contained gaseous material resulting from industrial, commercial, and agricultural operations. Soliç or dissolved material in domestic sewage flows are excluded. Special wastes (such as low-level radioactive wastes and RCRA and TSCA wastes) cannot be disposed of in a conventional facility. A feasibility study including system and site evaluations must be submitted to Ohio for approval for any contemplated construction or modification to a solid waste disposal or processing facility. Detailed design drawings, specifications, operating plans, and closure plans must be approved by Ohio prior to construction and operation. Records, plans, and capacities must also be provided to the state during operation.

Sanitary wastes: PORTS currently operates the $X-735$ sanitary landfill for the disposal of conventional (i.e., nonradioactive, nonhazardous, and non-PCB) solid wastes. X-735 is located on the North Access Road approximately $0.8 \mathrm{~km}$ north of the Perimeter Road. Disposal is by shallow land burial using the trench-and-fill method. The site has a permit and operating license from OEPA, and inspections are performed by the Pike County Department of Health. This permit allows disposal of asbestos and certain semisolid sludges.

Construction spoils: Construction spoils generated at PORTS have been disposed of in a construction spoils area. Near the X-735 sanitary landfill, a new spoils area was opened in 1989.

Waste oils: The X-740 facility is used to store drummed and bulk waste oils that are destined for recycling or use in a heat recovery program. The waste oils managed at X-740 are sampled and segregated for disposal. These oils are normally disposed of commercially. Oils believed to be contaminated by radioactivity or hazardous or toxic wastes are not stored at X-740. Waste oil stored at $\mathrm{X}-740$ that is subsequently found io contain hazardous or toxic constituents is moved to 
appropriate storage prior to disposal. Waste oil found to be radioactive will be disposed at the K-25 Site incinerator rather than commercially (see

Subsect. 8.6.2).

Fly ash disposal: PORTS disposes of fly ash and bottom ash generated at the X-600 steam plan in the $X-735$ sanitary landfill. OEPA approved a request to increase the amount of waste disposed at the X-735 landfill to allow the disposal of the ash. The old construction spoils landfill will be formally closed. A new spoils area was opened in 1989.

Clean scrap: Tons of uncontaminated or "clean" scrap metal are currently stored in designated areas at PORTS. The scrap is primarily ferrous and has resale value for outside commercial scrap dealers. Storage of the clean scrap presents very iittle impact in the way of environmental pollution. For security reasons the salvage yard is not located inside the secured area so that uncleared buyers and other personnel may have access to examine and to transport scrap metal.

Medical and infectious waite: PORTS generates three types of medical and infectious waste at the X-101 medical facility. These are (1) human blood and blood products, (2) contaminated sharps, and (3) expired drugs. The blood and blood products and the contaminated sharps are autoclaved prior to disposal to destroy any infectious content. Sharps are placed in a puncture-proof container prior to disposal. Disinfected and containerized blood and blood products and sharps are then disposed of in the sanitary landfill. Expired drugs are disposed of by commercial incineration.

Asbestos wastes: Asbestos wastes are regulated by the NESHAP regulations. Sources of asbestos are insulation around water and steam lines and other heat-related processes. When removed, the asbestos must be properly packaged and landfilled in a designated area of the X-735 sanitary landfill or the $\mathrm{X}-749$ contaminated materials disposal facility if contaminated with radioactivity. The areas where asbestos has been disposed of are specifically identified.

\subsubsection{Waste Management Facilities}

The primary waste management storage facilities at the PORTS site are shown in Fig. 8.1 and described as follows:
- The X-752 hazardous waste storage facility contains the RCRA wastes generated on the plant site that will be disposed of off-site either at a commercial disposal site or, if the waste has unacceptable uranium concentrations, at the TSCA incinerator at the $\mathrm{K}-25$ Site.

- Hazardous mixed wastes are stored in the X-744G bulk storage building and the X-326 process building. Areas in each of these buildings have been upgraded for the storage of hazardous wastes by installing dikes and sealing the floor.

- PCB wastes are stored in the X-333, X-330, and X-326 process buildings and in the $\mathrm{X}-334 \mathrm{PCB}$ transfer building.

- Waste oils that do not contain hazardous, toxic, or radioactive constituents are stored in the $\mathrm{X}-740$ waste oil storage facility and subsequently disposed of off-site. These oils are destined for recycling or use in a heat recovery program.

- Scrap metal, if radioactively contaminated, is stored at the $\mathrm{X}-747 \mathrm{H}$ salvage yard after it has been partially decontaminated (i.e., removable contamination has been removed). Nonradioactively contaminated scrap metal is stored near the surplus and salvage facility and is offered for sale to the general public. Scrap precious metals such as copper and nickel are stored at $\mathrm{X}-747 \mathrm{G}$ precious metal storage yard. Detoxified sludge from the closure of the X-616 chromium sludge surface impoundments is disposed of at this facility.

The waste management disposal facilities (primarily burial yards) are as follows:

- X-735, the sanitary landfill, is used for sanitary waste, and no free liquids, hazardous constituents, or radioactive materials are allowed in this facility. Asbestos is also disposed of at this facility in designated and segregated cells.

- $\mathrm{X}-749 \mathrm{~A}$ and $\mathrm{X}-749 \mathrm{C}$ are the classified material burial facilities. Only materials that are classified and not contaminated with hazardous or radioactive materials or free liquids can be buried in these facilities. There are no facilities on-site for classified radioactive or 


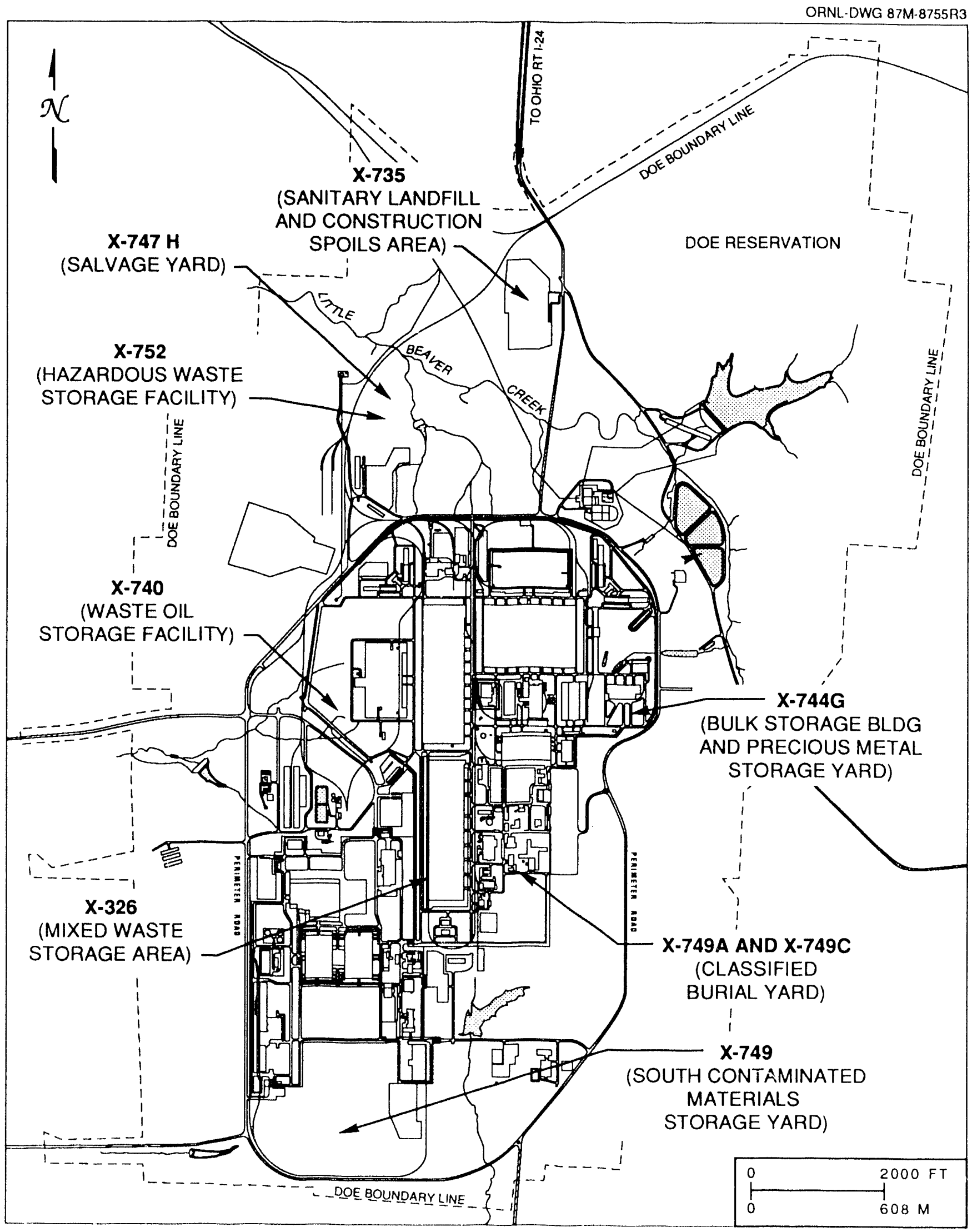

Fig. 8.1. Waste management storage facilities at PORTS. 
hazardous constituents burial. X-749 is to be closed by EPA mandate in 1990 . The X-749A facility ceased operations in 1990, and X-749C, a planned facility, has not begun operations.

- X-749 is the radioactively contaminated burial facility for radioactively contaminaied materials; waste disposed of there must not contain hazardous or classified material. Contaminated asbestos is also buried at this site.

- The X-736 construction spoils landfill, a new construction spoils area, was opened in 1989. Nonregulated materials such as construction and demolition debris are buried there to conserve the area dedicated for use as the X-735 sanitary landfill. These spoils must not contain any type of regulated waste.

\subsubsection{Off-Site Disposal Activities}

Incineration is the preferred method for off-site disposal of wastes, particularly hazardous and PCB wastes: however, landfills and other types of disposal are used as needed. For example, PCB-contaminated transformer carcasses cannot be incinerated and must be sent to an approved landfill. All commercial sites used for disposal have been inspected and approved by Energy Systems ESA personnel prior to shipping wastes to those sites. These inspections examine processes and review management systems, permits, and insurance information. Off-site disposals, as listed in Table 8.2 of Part 2, are arranged through the PORTS Waste Management, Purchasing, and Traffic Departments. Unless special circumstances dictate otherwise, all such disposals are awarded to the lowest qualified bidder. All waste-shipping containers must meet DOE specifications. Table 8.2 (Part 2) lists wastes shipped to the K-25 Site. These wastes are intended for eventual incineration at K-25; however, at present the wastes are being stored until the K-25 incinerator is operational. During CY 1990, off-site shipments of PCB and RCRA wastes totalling $109,964 \mathrm{~kg}$ (Part 2, Table 8.1) were made to two different sites. All of the disposals were, or will be, incinerated except for the landfilling of transformer carcasses.

\subsubsection{Waste Placed in Storage}

Low-level radioactive waste. Low-level radioactively contaminated wastes are currently segregated and handled as follows:

- Radioactively contaminated burnable trash (nonhazardous) is stored in retrievable storage canisters made of surplus converter shells. The supply of shells is nearly exhausted. These shells will be replaced with strong, tight containers purchased for this use and stored on a concrete pad. Examples of this material include contaminated wood, rags, plastic shoe covers, paper coveralls, other clothing articles, mop heads, plastic and paper sheeting, plastic bags, and boundary tapes. This burnable trash is being held for possible future incineration. If storage space becomes a severe problem, this trash will be reduced in volume.

- Radioactively contaminated nonburnable trash (nonhazardous) is stored in retrievable storage canisters made of surplus converter shells. The supply of shells is nearly exhausted. These shells will be replaced with strong, tight containers purchased for this use and stored on a concrete pad. Examples of this waste include contaminated metal turnings, concrete and asphalt, dirt and other construction spoils, drums, cans, and other miscellaneous nonburnables.

- Asbestos with known radioactive contamination is stored in 6-mil, double-walled polyethylene bags until disposal. Due to the losure activities at X-749, this material is being stored pending the development of new disposal capabilities.

- Nonhazardous chemical trap and filter wastes that have too little uranium to warrant uranium recovery have been disposed of in X-749 using trench and fill methods. Samples of this material are checked periodically for EP toxicity to ensure that no RCRA hazardous materials are buried. No free liquids are permitted. This material is specially packaged in plastic and inserted in wooden crates before burial. Burial practices comply with sanitary landfill regulations until closure in 1990. 
- Wastes containing highly mobile radioactive isotopes (e.g., technetium) in significant concentrations are stored.

A total of $3,057,000 \mathrm{~kg}$ of radioactively contaminated waste was generated and managed during 1990.

Contaminated PCB (mixed) wastes from process buildings. This waste is generated in the $X-333, X-330$, and $X-326$ process buildings through collection of floor sweepings, cleanup of lube oil leaks, and collection of ventilation duct seam seepage. All waste generated in the process buildings is assumed to be uranium contaminated and is placed into DOT specification drums for indefinite storage. Disposal of these materials is through incineration at the TSCA incinerator at the K-25 Site. A total of $165,823 \mathrm{~kg}$ of mixed PCB waste was entered into storage during CY 1990.

Contaminated hazardous (mixed) wastes. Most of this waste is generated from the raffinate treatment process in the X-705 building. The neutralization of the raffinate results in a sludge that is EP toxic with regard to cadmium and lead and contains low-level quantities of uranium and technetium. During CY $1990,96,098 \mathrm{~kg}$ of mixed hazardous waste resulting from routine operations was placed into storage. Additionally, due to closure activities at the X-701B Holding Pond, $3,666,000 \mathrm{~kg}$ of mixed hazardous waste was placed into storage.

Radioactively contaminated bulk scrap. A variety of scrap metal is stored at the existing $\mathrm{X}-747 \mathrm{H}$ salvage yard located at the northwest corner of the perimeter road. This yard is used for the storage of radioactively contaminated scrap metal and equipment. Scrap intended for storage in this yard is decontaminated of removable radioactive material before movement to the storage yard. This salvage yard will continue to operate as a storage area for radioactive scrap metal.

Lithium hydroxide storage. A supply of lithium hydroxide is stored in warehouses at PORTS. The containers had deteriorated, and the warehouses had degraded. A project to repair the buildings and to improve drainage has been completed. A project to repackage the deteriorated drums into overpack drums has been completed, and additional storage warehouses have been constructed to contain the larger volume that resulted from the repackaging. These projects will provide safe, long-term storage.

Hazardous waste storage and disposal. The $\mathrm{X}-752$ hazardous waste storage facility is an interim status facility for temporary storage of hazardous waste. During CY 1990, 162,196 kg of hazardous waste was máifested and entered into storage. During the year, hazardous waste amounting to $25,412 \mathrm{~kg}$ was shipped to commercial incinerators for destructive disposal.

PCB waste storage and disposal. During CY 1990 , a total of $7850 \mathrm{~L}$ of PCB-contaminated liquids and $20,027 \mathrm{~kg}$ of $\mathrm{PCB}$ equipment (e.g., capacitors, light ballasts) was placed into storage for disposal. A total of $47,315 \mathrm{~kg}$ of PCB and PCB-contaminated wastes was shipped for incineration, and $22 \mathrm{PCB}$ transformer carcasses were shipped to a secure chemical landfill. 


\section{SPECIAL STUDIES}

\subsection{PORTSMOUTH GASEOUS DIFFUSION PLANT SPILL REPORT}

The PORTS plant had a total of 152 spills and releases of various types during 1990 (see Table 9.1). Each of the spills or releases was investigated by PORTS shift superintendents, PORTS Environmental Safety and Health (ES\&H) staff, and other staff to determine the environmental impact, to provide input for reducing any harmful effects, and to monitor any potential health effects. Cleanup activitics were performed in accordance with PORTS standard operating procedures and were overseen by members of the ES\&H staff. The POR ${ }^{\mathrm{TS}}$ shift superintendents report all spills or releases to various levels of PORTS management and to DOE-ORO officials as appropriate.

Forty-one PCB-contaminated oil spills account for almost a third of the reported spills. Most of the reported oil spills amounted to new locations where drips from the ventilation ducts were found. There were 7 sanitary water breaks that resulted in the release of chlorine and 16 recirculating cooling water and recirculating heating water (RCW/RHW) line breaks that resulted in the release of chromium. Additionally, there were 17 releases of petroleum products, including releases from leaking underground storage tanks.

The magnitude of the spills ranged from gram quantities to an estimated several thousand pounds. Efforts to enhance spill/release prevention of all products are ongoing.

The increase in the number of spills and releases is proportional to the increased significance PORTS has placed on identifying and correcting environmental noncompliances. The total number of spills and releases also includes releases inside buildings that were cleaned up without impact to the environment.
Three notifications were made during 1990 for the exceedance of CERCLA Reportable Quantity $(R Q)$ releases. The first incident involved a spill of approximately 2700 pounds of sulfuric acid from the X-600 Steam Plant water softening unit to the South Holding Pond. The pond effluent was blocked immediately and the $\mathrm{pH}$ adjusted. The $\mathrm{pH}$ of the effluent to the Big Run Creek remained normal. The second incident involved a leaking PCB capacitor within a process building. An estimated 1 pint of oil was released. The spill was cleaned up and the equipment repaired. The third incident involves the continuous release of sodium dichromate (used for corrosion control) from the X-630 and X-633 Cooling Towers. The CERCLA RQ was changed from 1000 pounds to 10 pounds in 1989 . Sodium dichromate emissions were thought to be below the 10-pound level. However, new mass balance calculations showed emissions to be $19 \mathrm{lb} / \mathrm{d}$. PORTS is in the process of converting to a phosphate-based system.

\subsection{UNDERGROUND STORAGE TANKS (USTs)}

Underground Storage Tank (UST) activities were multi-faceted in CY 1990. Responsibilities for the UST Program are split between the Environmental Control and the Environmental Restoration departments. The two elements of the program are compliance with all applicable regulations and corrective actions when the environment has been contaminated. The UST Program is managed in accordance with EPA, OEPA, Ohio State Fire Marshal, and DOE regulations.

The State Fire Marshal UST Registration Permit Application was reviewed and updated. Tanks exempted or deferred from $r$, istration for various reasons (e.g., vaulted or flow-through tanks) were deleted from the application. PORTS maintains registration for 25 USTs, 3 of which are operated by 
Table 9.1. Spills and releases at PORTS during 1990

\begin{tabular}{lr}
\hline Acid & 10 \\
Mercury & 14 \\
PCB-contaminated oil & 41 \\
Other oil and & \\
petroleum products & 17 \\
RCW/RHW & 16 \\
Sanitary water & 7 \\
Miscellaneous & 47 \\
$\quad$ Total & 152 \\
\hline
\end{tabular}

the Defense Logistics Agency through a tenant agreement with DOE. Another five USTs are located on the PORTS reservation; however, they are registered and operated by the Ohio Army National Guard.

Three UST systems wer removed from the ground because they were no longer required. Additionally, one of the three USTs had been out of service for longer than 1 year.

Two UST systems were repaired. In one case, a supply line damaged during landscaping activities was repaired and the UST returned to service. In the second case, the supply lines were discovered to be delivering water. Excavation revealed the supply lines were not intact. The UST was fiberglass, and apparently was sound. The lines were replaced, spill/overfill equipment installed, a tightness test conducted, and the UST returned to service.

The Environmental Restoration Department undertook corrective actions at UST sites where contamination occurred. Where possible, the contaminated soil was removed for treatment and disposal. All excavated soils were tested for benzene, toluene, ethylbenzene and xylene (BTEX), total petroleum hydrocarbons (TPH) and lead contamination. Additional sampling for toxic characteristic leaching procedure BTEX and extraction procedure toxic metals analyses were conducted. After characterization, the soils were segregated based on contaminant levels. All soils were disposed of in the X-735 Sanitary Landfill. Soils above a performance standard (100 ppm TPH) were treated with microbial nutrients during placement in the landfill to enhance biodegradation.

An UST used to collect used oil was determined to be a hazardous waste tank. Operation of the tank was immediately halted. Its removal is pending EPA approval of the closure plan.

Two new double-walled fiberglass USTs were installed and placed in operation. They are fitted with spill/overfill equipment, an interstitial alarm system, and double-walled piping.

A contract was put in place with a consultant to review the available information on PORTS UST systems and to evaluate routinely generated level measurements in support of a release detection program. The consultant provided tank-specific "inches to gallons" conversion charts, inventory control/fuel handling procedures, and training. During the training, the UST operators were provided directions for the method of inventory control to be used on their tanks, inventory control forms, conversion charts, and spill/overfill procedures.

UST activities planned for 1991 include removing several more tanks that are no longer required, conducting required tightness tests, and reviewing inventory control level measurement data. 


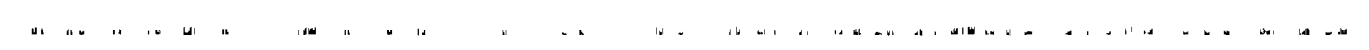




\section{QUALITY ASSURANCE}

Quality assurance (QA), an integral part of the environment:s surveillance effort, requires systematic control of the processes involved in sampling the environment and analyzing the samples. To achieve the desired level of control, PORTS uses the following major types of planned and systematic activities:

- implementation of standard operating procedures for sample collection and analysis,

- surveyor and analyst training and qualification,

- implementation of sample tracking and chain-of-custody procedures to ensure traceability and integrity of samples and data,

- participation in external control programs,

- frequent calibration and routine maintenance of measuring and test equipment,

- maintenance of internal control programs, and

- implementation of good measurement techniques and good laboratory practices.

Environmental sampling at PORTS is the responsibility of the Environmental Control Department. That department prepares sampling plans and procedures and selects the appropriate sampling instruments or devices in accordance with use and cleaning practices recommended by the American Society for Testing and Materials, EPA, or other authorities. Environmental Control also prepares chain-of-custody documentation from the point of sampling and properly protects the samples until they are transferred to the sample custodian at the laboratory.

The PORTS analytical laboratory has a QA coordinator who has general oversight for all phases of laboratory QA and who is administratively independent of the laboratory. In addition, the coordinator of the Laboratory Controls and Standards Group (LCSG) functions as a quality control (QC) officer administratively independent of the analytical laboratory. The LCSG operates the laboratory's central sample-receiving chain-of-custody facility and administers external and internal control programs. It generates internal QC samples using materials from the National Institute for Standards and Testing (NIST) or other reliable source materials and submits them to the laboratories on an established periodic basis. The LCSG performs statistical evaluations and issues QC reports to laboratory supervision and Environmental Control. The LCSG also generates control charts for the analytical laboratories. Good measurement practices in the laboratory include the use of matrix spikes, replicate analyses, check samples, and internal controls with the analysis of every batch of samples. Along with good measurement practices, the extensive internal QC Program ensures the reliability of the analytical data on a day-to-day basis.

Treating and interpreting analytical results are the responsibility of the Environmental Control Department. Because the volume of environmental surveillance data generated is large, the task for each monitoring program is compartmentalized to maintain responsible control. With the major objectives of protection of the public and protection of the environment, the data are reviewed as soon as they are available to establish regulatory compliance and to determine whether remedial action is needed. The data are reviewed periodically for overall interpretation and, where relevant, for their interprogram relationships. The documentation of the overall effort in periodic publications, such as this report, serves as a resource for future activity.

\subsection{FIELD SAMPLING AND MONITORING}

Personnel involved in field sampling and monitoring are trained and qualified and use approved procedures developed from guidelines and regulations promulgated by DOE and regulatory organizations such as EPA that exercise authority over activities on 
the plant site. These procedures spell out sampling protocol, sampling devices, and containers and preservatives to be used. Chain-of-custody procedures (in force for all sampling) are documented, and samples are controlled and protected from the point of sampling to the generation of analytical results.

\subsubsection{Basic Concepts and Practices}

Because data generated from field sampling can be greatly influenced by the methods used to collect and transport the samples, it is imperative that a QA Program be in place to guarantee that the data are generated accurately and that they reveal the conditions that exist in the environment at the time of sampling. The PORTS QA Program involves following written sampling procedures, using clean sampling devices and containers, employing approved sample-preservation techniques, and submitting field blanks and duplicate samples. Chain-of-custody procedures are followed strictly to ensure that sample integrity is maintained. Samples are delivered to the laboratory as soon as practicable after collection because some sample characteristics may be altered over time.

\subsubsection{Air Monitoring}

The PORTS air-monitoring network uses a pretreated filter-paper fluoride collector behind a Teflon particulate filter for collecting radionuclides and fluorides. The sample train uses materials that will not react with fluorides; this ensures that all gascous fluoride drawn into the sample train will reach the collector. The flow calibration of the devices that measure total air drawn through the sample trains during the sampling period is checked semiannually to ensure that results accurately reflect airborne concentrations. Written procedures are in place to guide personnel in collecting and analyzing the samples and checking the calibration of the air-metering device.

\subsubsection{Surface Water Monitoring}

Liquid effluent streams from PORTS are sampled and analyzed in compliance with the NPDES discharge permit. Written procedures are used by personnel for both sampling and analyzing these effluent streams. Flow and $\mathrm{pH}$ are continuously measured and recorded at several discharge points.
The calibration of the instrumentation is checked weekly to ensure that reliable data are being collected. Weekly composite samples are collected at two of the NPDES sample sites and one receiving stream site and measured for radioactive constituents. Once a month, two of these composite samples and an upstream sample from the receiving stream are split and shared with the Ohio Department of Health, Radiological Health Division, for analysis in its laboratory. Comparisons of data from the two laboratories show close correlation. Agreement with the state laboratory is another indicator of the quality of performance by the PORTS analytical laboratories.

\subsubsection{Groundwater Monitoring}

The extensive PORTS Groundwater Monitoring Program uses individually dedicated pumps and delivery lines to purge and pump wells. Dedicated equipment eliminates cross contamination of wells and samples. Written procedures are used for both collecting and analyzing samples. Field blanks and duplicate samples also are submitted to the laboratory to ensure that sampling techniques are not influencing the data being collected.

\subsubsection{Biological Monitoring}

Biological monitoring at PORTS in 1990 included fish from receiving streams, food crops grown outside the reservation, and grass from outside the reservation. Randomly selected duplicate samples are submitted to verify the reliability of sampling and analytical procedures. Written procedures are used in collecting and analyzing these samples.

\subsubsection{Soil and Sediment}

Soil from the area around the PORTS reservation and sediment from streams that receive liquid plant discharges are collected semiannually and analyzed for parameters that would indicate the influence that plant operations have on the sampled media. These samples are collected by field technicians who follow written procedures for sample collection. Duplicate samples are collected at randomly selected sites to verify the integrity of the sampling techniques.

\subsubsection{External Gamma Radiation}

Measurements of external gamma levels on and around the PORTS site are made according to a 
written procedure based on ANSI guidelines (ANSI 1975). Thermoluminescent dosimeters (TLDs) are installed, collected, and evaluated by Environmental Control Department personnel. Each TLD contains two TL chips that are treated as duplicate samples, and any TLD whose individual chips show significantly different results is tested for accuracy and validity before either result is used. All TLDs not being tested for validity are used to reestablish a group-specific calibration curve after each exposure cycle. Each calibration curve and data set is compared with previous calibration curves and filed with TLD results as an ongoing check against deterioration. Control TLDs are used to document extraneous exposures, and reference TLDs are used to measure TLD fading and to establish a correction factor using the midcycle exposure method.

\subsubsection{Waste-Monitoring Program}

Because solid wastes exist in various forms, several sampling and monitoring methods have been developed and instituted. The sampling and analyses of solid wastes at PORTS are accomplished using approved EPA procedures (EPA November 1986). These methods include the design and use of sampling equipment, method for calculating the number and pattern of samples to be collected to ensure that the average properties of the waste are represented, and analytical methods to be used. When feasible, duplicate samples are collected or replicate analyses are run to ensure reliability of the analytical data.

\subsection{ANALYTICAL QUALITY ASSURANCE}

The PORTS analytical laboratory continues a long tradition of QA and has a well-established QA Program. Integral to this program are a highly trained, well-qualified staff; use of approved and documented procedures and current analytical methodology; availability of excellent equipment and facilities; and routine use of accepted laboratory practices and measurement techniques. As part of the QA effort, the analytical laboratory maintains comprehensive internal QC programs, participates in a number of external QC programs, and uses statistical interpretation extensively to evaluate its performance.
The laboratory meets the $\mathrm{QA} / \mathrm{QC}$ requirements mandated by OEPA, EPA, and DOE. These requirements are an integral part of the laboratory $Q A$ programs. Analyses are performed using EPA-approved methods or other approved methods when available. Listings of analytical methods and lowest concentrations reported are given in Tables 10.1-10.5 of Part 2.

\subsubsection{Internal Quality Control}

The internal QC programs are the basis for ensuring reliable analytical results on a day-to-day and batch-to-batch basis. The total effort in these programs averages 10 to $20 \%$ of the laboratory effort (in accordance with EPA expectations). In 1990, PORTS analyzed 3000 internal environmental controls. The QC programs also frequently serve as the basis for on-the-job training and qualification of laboratory analysts performing environmental analyses. The internal QC programs are administered by the LCSG independent of the analytical laboratories. The LCSG is responsible for preparing known and blind controls and statistical evaluation of the QC programs.

All analytical activities are supported by the routine use of either standard or reference materials from NIST, EPA, other DOE laboratories, or other reliable sources. Quality control is accomplished through the use of such materials for instrument standardization; preparation of known, blind, and double blind controls; yield/efficiency determinations; and spike recoveries. The results of the blind-control programs, as well as a number of known-control programs, are statistically evaluated and reported to the laboratories and their customers. These reports assist in assessing the adequacy of analytical programs and procedures. If serious deviations are noted by the $\mathrm{QC}$ groups, the operating laboratories are promptly notified so that corrective actions can be initiated. Quality control data are stored retrievably so they can be related to the analytical results they support. The analytical laboratory has well-established QC for routine measured parameters in all types of environmental samples, and these parameters are shown in Table 10.1. 


\subsubsection{External Quality Control}

In addition to the internal QC programs, PORTS, like all Energy Systems installations, is directed by DOE and by EPA regulators to participate in external $\mathrm{QC}$ programs. These programs generate data that serve as a periodic indicator of performance. Although participation is expected, the degree of participation by each laboratory is voluntary; thus, the analytical parameters selected are of particular interest to that plant. These control programs are administered by EPA, DOE, and commercial laboratories.

\subsubsection{Radiological quality control}

In 1990, the PORTS analytical laboratory participated in two external radiological QC programs: the EPA Intercomparison Radionuclide Control Program and the DOE Environmental Measurements Laboratory (EML) Radionuclide Quality Assessment Program. The EPA Radionuclide Control Program is administered by the EPA

Environmental Monitoring System Laboratory at Las Vegas. During 1990, in conjunction with this control program, the PORTS laboratory performed a total of seven analyses on four parameters (two analyses each on alpha and beta, two analyses on uranium, and one analysis on plutonium). As is shown in Table 10.6 of Part 2, five results were within the acceptable range, and two results were unacceptable.

The DOE-EML Quality Assessment Program is administered by DOE's EML in New York. Various matrix samples such as water, air filters, soil, tissue, and vegetation are analyzed semiannually for a variety of radioactive isotopes; a statistical report is submitted by EML for each period. PORTS results for this program, reported in $\Xi$ ML 525, are shown in Table 10.7 of Part 2. Of the 16 analyses performed in this program, 15 results were in the acceptable range. One result was unacceptaile, but because all of the program participants reported unacceptable results in this case, the reference value is suspect.

\subsubsection{Nonradioactive quality control}

Nonradiological QC programs in which the PORTS laboratory participated during 1990 included inc Proficienc) Environmental Testing (PET) Program, the EF A Discharge Monitoring Report (DMR) QA Study, the Pittsburgh Energy Technology Center (PETC) Coà! Program, the National Institute of Occupational Safety and Health (NIOSH) Proficiency Analytical Testing (PAT) Program, and the NIST National Voluntary Laboraiory Accreditation Program (NVLAP).

PET Program. The PET Program is a commercial control program for environmental analysis sponsored by Analytical Products Group (APG), a commercial laboratory. Samples at two concentration levels representing a wide variety of environmental parameters are distributed monthly to more than 50 laboratories nationwide. Results are statistically evaluated by APG, and reports are then issued to each participating laboratory approximately 3 weeks after submission of data to APG. For each analysis, the report includes two evaluations as a measure of performance: percent recovery of the reference value (which is based on APG's reference value for the analyte) and deviation from the mean result of all reporting laboratories in the program (which provides a performance comparison with all participants).

Data generated by the PORTS analytical laboratory in the PET Program during 1990 are given in Table 10.8 of Part 2. For each of the two performance measures (percent recovery and standard deviation from the mean), the results of both high and low concentrations for each parameter are averaged. The performance evaluation of acceptable results, however, is not based on averages. Instead, it is based on the individual standard deviation of the mean of all participating laboratories for each analysis. Therefore, for a parameter analyzed each month at two concentrations, there are 24 performance indicators (acceptable, marginal, or unacceptable results) for the year. One thousand and one analyses representing 40 parameters were performed. Of these analyses, results for 978 were acceptable, 14 were marginal, and 9 were unacceptable. Because there were no more than three unacceptable values for any parameter, no trends could be identified to explain unacceptable results.

EPA DMR QA Study. EPA conducts a national QA program in support of the NPDES program. A.I holders of major NPDES permits are required to participate. EPA furnishes the QC samples and evaluates the results. Data representing PORTS participation in this program during 1990 are shown in Table 10.9 of Part 2. Results were obtained for 18 analytes. Two marginal results were obtained for 
nickel and nitrate as nitrogen; all other results were acceptable.

DOE/PETC Coal Program. In the DOE/PETC Coal Program, coal is analyzed for volatile matter, fixed carbon, ash, sulfur, and heating value. From an environmental standpoint, the ash, sulfur, and heating values results are of prime importance. The results of PORTS participation in the PETC Program during 1990 are shown in Table 10.10 of Part 2. Three samples were analyzed-each for five parameters. Acceptable results were obtained in all cases.

NIOSH PAT Program. Over 620 laboratories nationwide participate in NIOSH's PAT Program. Although its primary purpose is to support safety and health programs, the PAT Program includes a nimber of parameters that also represent environmental concerns. Therefore, PORTS 1990 PAT Program data are presented in Table 10.11 of Part 2 as a further indicator of performance in environmental analyses. During the course of the year, there were four rounds of program participation. In each round, four analyses were performed for each of eight parameters (lead, cadmium, zinc, silica, asbestos, and three organic solvents). Of the 128 results, only 6 were designated "outliers" by NIOSH. Because of high performance, PORTS maintained its proficiency rating in the PAT Program for all parameters tested during 1990.

NIST-NVLAP Program for Bulk Asbestos. In 1990 the PORTS laboratory was accredited by NIST for the analysis of bulk asbestos by polarized light microscopy under NVLAP. Laboratory accreditation is based on the implementation of an extensive QA/QC Program, assessment of laboratory operations by the NVLAP technical representative, and satisfactory completion of all proficiency samples. Accreditation is granted for one year and is subject to continual demonstrated proficiency. PORTS has satisfactorily completed all proficiency checks conducted by NIST during 1990.

\subsection{AUDITS AND REVIEWS}

The PORTS Environmental Protection Program undergoes rigorous annual appraisals, audits, and reviews by organizations both internal and external. All appraisals, audits, and reviews may result in recommendations requiring operating contractor management attention. Recommendations on environmental issues result in the development and implementation of corrective actions formulated to improve overall site environmental protection.
Internal organizations that conduct periodic reviews of the Environmental Protection Program include Contractor Self-Appraisal Program coordinators and the Internal Audit and QA Department. Although the appraisals, audits, and reviews performed by these organizations might seem redundant, many areas addressed are reviewed with different criteria by various organizations.

Appraisals, audits, and/or reviews of the site Environmental Protection Program conducted during 1990 included a Multi-Media Environmental Audit by EPA in August; a RCRA Compliance Inspection by Ohio EPA in September; a Corporate Audit Review by Martin Marietta Energy Systems (MMES) in October; a follow-up Tiger Team Review by DOE in October; an Environmental Compliance Review by MMES in November; and an Environmental Restoration and Waste Management Audit by DOE in December.

The EPA Multi-Media Environmental Audit was conducted August 15-17. The audit evaluated the Clean Water Act, Toxic Substances Control Act, Clean Air Act, underground storage tanks, and Federal Insecticide, Fungicide, and Rodenticide Act (FIFRA).

The compliance inspection by Ohio EPA was conducted September 12-14; all areas of RCRA Compliance, including record-keeping and compliance inspections required by RCRA regulations, were reviewed. PORTS responded to all deficiencies identified during the inspection.

A Corporate Audit Review was conducted October 2-5; all programs in Environmental Compliance were reviewed. Field surveys were conducted to identify any environmental deficiencies on the plant site.

A follow-up review of the DOE Tiger Team Audit was conducted October 22-26; all closed Tiger Team findings were reviewed and closure status was validated.

An Environmental Compliance Review was conducted November 5-16; the review addressed all Environmental Compliance Programs. Field surveys were conducted and internal environmental records were reviewed.

DOE conducted an audit of the Environmental Restoration (ER) and Waste Management (WM) programs December 19-21; the audit concentrated on QA/QC for ER and management of RCRA hazardous waste for WM. 


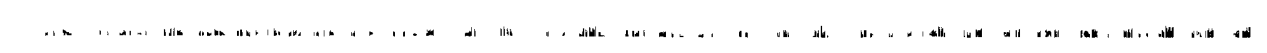


1. INTRODUCTION 
All information for this section is presented in Part 1. 
2. AIRBORNE DISCHARGES, AMBIENT AIR MONITORING, METEOROLOGICAL MONITORING, AND EXTERNAL GAMMA RADIATION 
Table 2.1. $1990 \mathrm{X}-600$ steam plant opacity compliance

\begin{tabular}{cccc}
\hline Quarter & $\begin{array}{c}\text { Total minutes } \\
\text { of operation }\end{array}$ & $\begin{array}{c}\text { Total minutes } \\
\text { out of compliance }\end{array}$ & $\begin{array}{c}\text { Percent of time } \\
\text { in compliance }\end{array}$ \\
\hline 1 & 257,640 & 138 & 99.95 \\
2 & 259,525 & 102 & 99.96 \\
3 & 258,315 & 198 & 99.92 \\
4 & 263,090 & 228 & 99.91 \\
\hline
\end{tabular}

Table 2.2A. 1990 X-600 steam plant coal delivery and analysis data

\begin{tabular}{lccccc}
\hline Month & $\begin{array}{c}\text { Tons of coal } \\
\text { delivered }\end{array}$ & \% Ash & $\% \mathrm{~S}$ & $\begin{array}{c}\mathrm{SO}_{2} \\
\text { lb/M Btu }\end{array}$ & $\begin{array}{c}\text { Tons } \mathrm{SO}_{2} \\
\text { generated }\end{array}$ \\
\hline January & 4,566 & 12.31 & 4.64 & 7.10 & 403 \\
February & 5,502 & 11.44 & 4.05 & 6.12 & 423 \\
March & 3,673 & 11.88 & 4.20 & 6.39 & 293 \\
April & 3,052 & 9.39 & 3.72 & 5.51 & 216 \\
May & 2,581 & 9.95 & 1.30 & 1.88 & 64 \\
June & 3,911 & 8.47 & 1.21 & 1.74 & 90 \\
July & 3,245 & 6.85 & 3.23 & 4.62 & 199 \\
August & 3,926 & 6.89 & 2.89 & 4.17 & 216 \\
September & 3,550 & 7.78 & 3.19 & 4.64 & 215 \\
October & 3,094 & 7.06 & 2.94 & 4.23 & 173 \\
November & 3,190 & 7.53 & 3.20 & 4.84 & 194 \\
December & 3,492 & 7.43 & 3.03 & 4.35 & 201 \\
\hline & & & & 2,687 \\
\hline
\end{tabular}


Table $2.2 \mathrm{~B}$. $1990 \mathrm{X}-600$ steam plant coal delivery and analysis data quarterly averages

\begin{tabular}{|c|c|c|c|}
\hline Quarter & $\%$ Ash & $\% \mathrm{~S}$ & $\begin{array}{c}\mathrm{SO}_{2} \\
\mathrm{lb} / \mathrm{M} \mathrm{Btu}\end{array}$ \\
\hline $\begin{array}{l}1 \mathrm{Q} \\
2 \mathrm{Q} \\
3 \mathrm{Q} \\
4 \mathrm{Q}\end{array}$ & $\begin{array}{r}11.85 \\
9.16 \\
7.17 \\
7.35\end{array}$ & $\begin{array}{l}4.29 \\
2.04 \\
3.09 \\
3.06\end{array}$ & $\begin{array}{l}6.50 \\
2.95 \\
4.46 \\
4.54\end{array}$ \\
\hline Annual average & 9.11 & 3.23 & 4.77 \\
\hline
\end{tabular}

Table 2.3. 1990 PORTS $(50-\mathrm{m})$ radionuclide emissions

\begin{tabular}{lccccccc}
\hline \multicolumn{1}{c}{ Month } & $\begin{array}{c}{ }^{234} \mathrm{U} \\
(\mathrm{mCi})\end{array}$ & $\begin{array}{c}{ }^{235} \mathrm{U} \\
(\mathrm{mCi})\end{array}$ & $\begin{array}{c}{ }^{236} \mathrm{U} \\
(\mathrm{mCi})\end{array}$ & $\begin{array}{c}{ }^{238} \mathrm{U} \\
(\mathrm{mCi})\end{array}$ & $\begin{array}{c}\text { Uranium } \\
(\mathrm{kg} \mathrm{U})\end{array}$ & $\begin{array}{c}99 \mathrm{Tc} \\
(\mathrm{mCi})\end{array}$ & $\begin{array}{c}\mathrm{U}^{2} \text { Dau. } \\
(\mathrm{mCi})\end{array}$ \\
\hline January & 4.24 & 0.131 & 0.0006 & 0.015 & 0.109 & 1.37 & 0.162 \\
February & 3.63 & 0.111 & 0.0006 & 0.022 & 0.118 & 1.47 & 0.155 \\
March & 1.90 & 0.056 & 0.0006 & 0.02 & 0.086 & 5.99 & 0.096 \\
April & 2.66 & 0.091 & 0.0006 & 0.624 & 0.115 & 2.26 & 0.139 \\
May & 2.80 & 0.067 & 0.0002 & 0.028 & 0.116 & 2.21 & 0.123 \\
June & 2.66 & 0.091 & 0.0003 & 0.035 & 0.149 & 2.21 & 0.161 \\
July & 2.40 & 0.082 & 0.0002 & 0.043 & 0.168 & 2.82 & 0.168 \\
August & 2.25 & 0.074 & 0.0002 & 0.045 & 0.172 & 2.50 & 0.165 \\
September & 0.94 & 0.043 & 0.0006 & 0.036 & 0.129 & 1.71 & 0.115 \\
October & 0.66 & 0.025 & 0.0002 & 0.019 & 0.068 & 6.01 & 0.062 \\
November & 2.21 & 0.071 & 0.0002 & 0.054 & 0.197 & 5.85 & 0.179 \\
Decemt & 2.00 & 0.067 & 0.0007 & 0.043 & 0.161 & 2.45 & 0.153 \\
Misc. & 1.04 & 0.042 & 0.0001 & 0.021 & 0.083 & 0.17 & 0.085 \\
\multicolumn{1}{c}{ Total (50-m) } & 29.39 & 0.951 & 0.0052 & 0.406 & 1.671 & 37.01 & 1.763 \\
\hline
\end{tabular}

Uranium daughters. 
Table 2.4. 1990 PORTS $(20-\mathrm{m})$ radionuclide emissions

\begin{tabular}{|c|c|c|c|c|c|c|c|}
\hline Month & $\begin{array}{l}{ }^{234} \mathrm{U} \\
(\mathrm{mCi})\end{array}$ & $\begin{array}{l}{ }^{235} \mathrm{U} \\
(\mathrm{mCi})\end{array}$ & $\begin{array}{l}{ }^{236} \mathrm{U} \\
(\mathrm{mCi})\end{array}$ & $\begin{array}{l}{ }^{23 \circ} \mathrm{U} \\
(\mathrm{mCi})\end{array}$ & $\begin{array}{c}\text { Uranium } \\
(\mathrm{kg} \mathrm{U})\end{array}$ & $\begin{array}{l}{ }^{99} \mathrm{Tc} \\
(\mathrm{mCi})\end{array}$ & $\begin{array}{c}\text { U. Dau. }^{a} \\
(\mathrm{mCi})\end{array}$ \\
\hline January & 2.729 & 0.066 & 0.00023 & 0.277 & 0.865 & 0.95 & 0.620 \\
\hline February & 2.395 & 0.024 & 0.00010 & 0.181 & 0.557 & 0.70 & 0.387 \\
\hline March & 0.781 & 0.011 & 0.00008 & 0.118 & 0.361 & 1.01 & 0.247 \\
\hline April & 0.964 & 0.011 & 0.00009 & 0.074 & 0.227 & 0.77 & 0.158 \\
\hline May & 0.612 & 0.005 & 0.00004 & 0.064 & 0.196 & 0.75 & 0.134 \\
\hline June & 0.763 & n.m6 & 0.00005 & 0.056 & 0.170 & 0.99 & 0.117 \\
\hline July & 0.336 & 0.005 & 0.00002 & 0.028 & 0.086 & 0.80 & 0.061 \\
\hline August & 0.397 & 0.015 & 0.00006 & 0.113 & 0.348 & 1.11 & 0.242 \\
\hline September & 0.130 & 0.006 & 0.00006 & 0.054 & 0.166 & 2.34 & 0.115 \\
\hline October & 0.122 & 0.006 & 0.00002 & 0.029 & 0.091 & 0.58 & 0.064 \\
\hline November & 0.141 & 0.006 & 0.00004 & 0.080 & 0.244 & 1.30 & 0.167 \\
\hline December & 0.097 & 0.005 & 0.00004 & 0.070 & 0.213 & 0.67 & 0.145 \\
\hline Misc. & 0.085 & 0.003 & 0.00001 & 0.009 & 0.029 & 0.46 & 0.021 \\
\hline Total $(20-m)$ & 9.552 & 0.168 & 0.00085 & 1.155 & 3.555 & 12.45 & 2.478 \\
\hline
\end{tabular}

${ }^{a}$ Uranium daughters. 
Table 2.5. 1990 airborne gross alpha radiation concentrations $\left(\mathrm{pCl} / \mathrm{m}^{3}\right)$

\begin{tabular}{|c|c|c|c|c|c|c|c|c|c|}
\hline Month & $\begin{array}{c}\mathrm{A} 3 \\
\mathrm{~S}\end{array}$ & $\begin{array}{l}\text { A15 } \\
\text { SE }\end{array}$ & $\begin{array}{c}\mathrm{A} 12 \\
\mathrm{E}\end{array}$ & $\begin{array}{l}\mathrm{A} 23 \\
\mathrm{NE}\end{array}$ & $\begin{array}{c}\mathrm{A} 24 \\
\mathrm{~N}\end{array}$ & $\begin{array}{c}\text { A8 } \\
\text { NW }\end{array}$ & $\begin{array}{c}\text { A29 } \\
W\end{array}$ & $\begin{array}{l}\text { A9 } \\
\text { SW }\end{array}$ & $\begin{array}{l}\text { A28 } \\
\text { Bkg }\end{array}$ \\
\hline January & 0.011 & 0.006 & 0.005 & 0.003 & 0.003 & 0.004 & 0.002 & 0.006 & 0.006 \\
\hline February & 0.009 & 0.004 & 0.000 & 0.003 & 0.000 & 0.005 & 0.003 & 0.004 & 0.000 \\
\hline March & 0.004 & 0.003 & 0.004 & 0.005 & 0.002 & 0.004 & 0.006 & 0.001 & 0.008 \\
\hline April & -0.003 & 0.009 & 0.000 & 0.003 & 0.010 & 0.002 & 0.001 & 0.000 & 0.008 \\
\hline May & 0.012 & 0.011 & 0.004 & 0.003 & 0.002 & 0.002 & 0.003 & 0.010 & 0.002 \\
\hline June & -0.001 & 0.002 & 0.002 & 0.002 & 0.001 & 0.001 & 0.001 & 0.003 & 0.005 \\
\hline July & & 0.000 & 0.091 & -0.001 & -0.001 & -0.001 & 0.001 & 0.000 & 0.001 \\
\hline August & & 0.005 & 0.002 & 0.005 & 0.007 & 0.004 & 0.002 & 0.010 & 0.005 \\
\hline September & 0.002 & 0.004 & 0.008 & 0.005 & 0.005 & 0.002 & 0.003 & 0.003 & 0.001 \\
\hline October & 0.004 & 0.003 & 0.003 & 0.006 & 0.005 & 0.005 & 0.007 & 0.001 & 0.005 \\
\hline November & 0.002 & 0.004 & 0.008 & 0.005 & 0.004 & 0.003 & 0.004 & 0.003 & 0.002 \\
\hline December & 0.008 & 0.007 & 0.004 & 0.002 & 0.001 & 0.005 & 0.004 & 0.002 & 0.005 \\
\hline Month & $\begin{array}{c}\text { A6 } \\
\text { Pike }\end{array}$ & $\begin{array}{c}\mathrm{A} 10 \\
\mathrm{X}-230-\mathrm{J} 3 \\
\end{array}$ & $\begin{array}{c}\mathrm{A} 35 \\
\mathrm{X}-230-\mathrm{J} 2 \\
\end{array}$ & $\begin{array}{c}\text { A36 } \\
X-611 \\
\end{array}$ & $\begin{array}{c}\mathrm{A} 38 \\
\mathrm{X}-230-\mathrm{J} 8 \\
\end{array}$ & $\begin{array}{c}\text { A39 } \\
X-760 \\
\end{array}$ & $\begin{array}{c}\text { A40 } \\
X-100\end{array}$ & $\begin{array}{l}\text { A37 } \\
\text { Bkg }\end{array}$ & \\
\hline January & 0.005 & 0.003 & 0.005 & 0.006 & 0.009 & 0.012 & 0.006 & 0.003 & \\
\hline February & -0.001 & 0.003 & 0.001 & 0.002 & 0.003 & 0.013 & 0.007 & 0.002 & \\
\hline March & 0.015 & 0.003 & 0.005 & 0.005 & 0.007 & 0.006 & 0.006 & 0.002 & \\
\hline Aprii & 0.002 & 0.003 & 0.005 & 0.001 & 0.001 & 0.008 & 0.004 & 0.002 & \\
\hline May & 0.004 & 0.008 & 0.007 & 0.009 & 0.008 & 0.020 & 0.010 & 0.005 & \\
\hline June & 0.004 & 0.000 & 0.004 & 0.002 & 0.004 & 0.007 & 0.009 & -0.000 & \\
\hline July & 0.003 & 0.004 & 0.001 & 0.002 & 0.003 & 0.011 & 0.005 & 0.002 & \\
\hline August & 0.005 & 0.011 & 0.009 & 0.003 & 0.005 & 0.005 & 0.008 & 0.005 & \\
\hline September & 0.001 & 0.004 & 0.008 & 0.004 & 0.002 & 0.010 & 0.007 & 0.002 & \\
\hline October & 0.012 & 0.002 & 0.005 & 0.006 & 0.002 & 0.004 & 0.004 & 0.001 & \\
\hline November & 0.007 & 0.004 & 0.003 & 0.006 & 0.004 & 0.006 & 0.010 & 0.006 & \\
\hline December & 0.007 & 0.002 & 0.003 & 0.005 & 0.006 & 0.002 & 0.003 & 0.001 & \\
\hline
\end{tabular}


Table 2.6. 1990 airborne gross beta-gamma radiation concentrations $\left(\mathrm{pCi} / \mathrm{m}^{3}\right)$

\begin{tabular}{|c|c|c|c|c|c|c|c|c|c|}
\hline Month & $\begin{array}{c}\mathrm{A3} \\
\mathrm{S}\end{array}$ & $\begin{array}{l}\text { A15 } \\
\text { SE }\end{array}$ & $\begin{array}{c}\mathrm{A} 12 \\
\mathrm{E}\end{array}$ & $\begin{array}{l}\text { A23 } \\
\text { NE }\end{array}$ & $\begin{array}{c}\mathrm{A} 24 \\
\mathrm{~N}\end{array}$ & $\begin{array}{c}\text { A8 } \\
\text { NW }\end{array}$ & $\begin{array}{l}\text { A29 } \\
W\end{array}$ & $\begin{array}{l}\text { A9 } \\
\text { SW }\end{array}$ & $\begin{array}{l}\text { A28 } \\
\text { Bkg }\end{array}$ \\
\hline January & 0.042 & 0.040 & 0.041 & 0.033 & 0.039 & 0.045 & 0.011 & 0.040 & 0.061 \\
\hline February & 0.029 & 0.028 & 0.026 & 0.026 & 0.033 & 0.029 & 0.026 & 0.024 & 0.047 \\
\hline March & 0.034 & 0.022 & 0.024 & 0.021 & 0.034 & 0.020 & 0.018 & 0.029 & 0.052 \\
\hline April & 0.000 & 0.024 & 0.026 & 0.019 & 0.026 & 0.019 & 0.025 & 0.018 & 0.046 \\
\hline May & 0.043 & 0.034 & 0.007 & 0.023 & 0.020 & -0.001 & 0.010 & 0.022 & 0.032 \\
\hline June & 0.019 & 0.014 & 0.021 & 0.018 & 0.013 & 0.017 & 0.023 & 0.020 & 0.040 \\
\hline July & & 0.020 & 0.021 & 0.003 & 0.018 & 0.026 & 0.030 & 0.017 & 0.028 \\
\hline August & & 0.033 & 0.001 & 0.027 & 0.034 & 0.025 & 0.020 & 0.031 & 0.039 \\
\hline September & 0.027 & 0.048 & 0.037 & 0.024 & 0.050 & 0.040 & 0.031 & 0.041 & 0.046 \\
\hline October & 0.034 & 0.033 & 0.039 & 0.034 & 0.041 & 0.033 & 0.041 & 0.032 & 0.056 \\
\hline November & 0.035 & 0.048 & 0.045 & 0.051 & 0.045 & 0.035 & 0.043 & 0.042 & 0.050 \\
\hline December & 0.045 & 0.061 & 0.043 & 0.035 & 0.007 & 0.028 & 0.045 & 0.025 & 0.051 \\
\hline Month & $\begin{array}{c}\text { A6 } \\
\text { Pike }\end{array}$ & $\begin{array}{c}\mathrm{A} 10 \\
\mathrm{X}-230-\mathrm{J} 3\end{array}$ & $\begin{array}{c}\text { A35 } \\
\mathrm{X}-230-\mathrm{J} 2\end{array}$ & $\begin{array}{c}\text { A36 } \\
X-611\end{array}$ & $\begin{array}{c}\text { A38 } \\
X-230-J 8\end{array}$ & $\begin{array}{c}\text { A39 } \\
X-760\end{array}$ & $\begin{array}{c}\mathrm{A} 40 \\
\mathrm{X}-100\end{array}$ & $\begin{array}{l}\text { A37 } \\
\text { Bkg }\end{array}$ & \\
\hline January & 0.037 & 0.038 & 0.039 & 0.025 & 0.228 & 0.049 & 0.032 & 0.036 & \\
\hline February & 0.033 & 0.021 & 0.025 & 0.013 & 0.020 & 0.041 & 0.036 & 0.016 & \\
\hline March & 0.041 & 0.033 & 0.030 & 0.029 & 0.024 & 0.031 & 0.027 & 0.032 & \\
\hline April & 0.039 & 0.028 & 0.024 & 0.028 & 0.009 & 0.038 & 0.048 & 0.020 & \\
\hline May & 0.040 & 0.030 & 0.016 & 0.023 & 0.023 & 0.036 & 0.031 & 0.022 & \\
\hline June & 0.025 & 0.024 & 0.017 & 0.021 & 0.010 & 0.020 & 0.029 & 0.018 & \\
\hline July & 0.027 & 0.016 & 0.014 & 0.016 & 0.036 & 0.020 & 0.035 & 0.024 & \\
\hline August & 0.031 & 0.035 & 0.041 & 0.022 & 0.027 & 0.021 & 0.045 & 0.023 & \\
\hline September & 0.051 & 0.033 & 0.036 & 0.034 & 0.009 & 0.042 & 0.036 & 0.028 & \\
\hline Octoher & 0.057 & 0.034 & 0.043 & 0.271 & 0.030 & 0.288 & 0.048 & 0.012 & \\
\hline November & 0.078 & 0.037 & 0.043 & 0.038 & 0.033 & 0.047 & 0.053 & 0.063 & \\
\hline December & 0.078 & 0.055 & 0.038 & 0.046 & 0.046 & 0.034 & 0.036 & 0.047 & \\
\hline
\end{tabular}




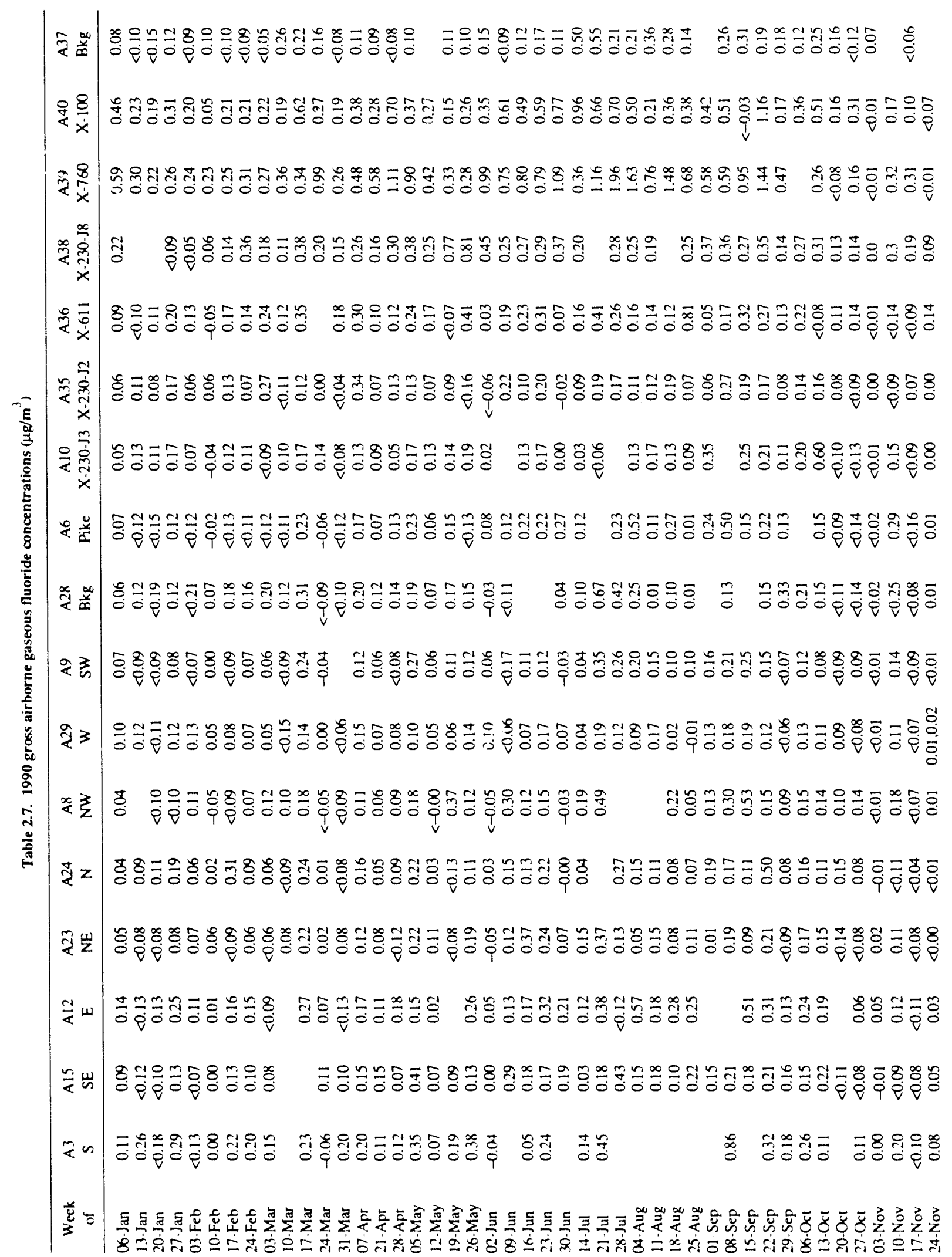




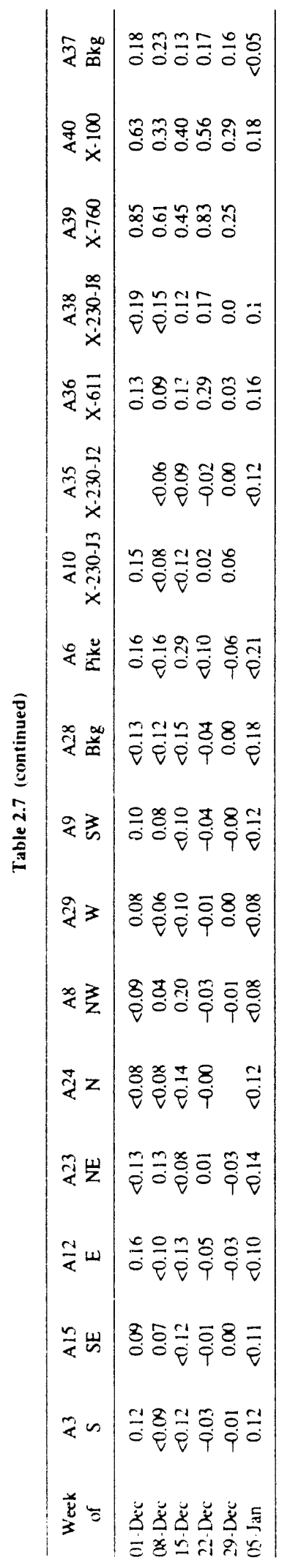


Table 2.8. PORTS ambient air station locations

\begin{tabular}{|c|c|c|}
\hline Designation & Location & Direction \\
\hline \multicolumn{3}{|c|}{ On-site air-sampling stations } \\
\hline $\mathrm{A} 40$ & $\mathrm{X}-100$ administration building penthouse & NA \\
\hline $\mathrm{A} 35$ & $\begin{array}{l}\mathrm{X}-230-\mathrm{J} 2 \text { south (holding pond) environmental } \\
\text { monitoring station }\end{array}$ & $\mathrm{S}$ \\
\hline A10 & $\begin{array}{l}\text { X-230-J3 west (ditch) environmental monitoring } \\
\text { station }\end{array}$ & W \\
\hline A38 & $\begin{array}{l}\text { X-230-J8 environmental storage building, } \\
\text { southeast comer of main parking lot }\end{array}$ & ESE \\
\hline A36 & $\begin{array}{l}\text { X-611 water treatment plant, southeast corner } \\
\text { of facility parking lot }\end{array}$ & ENE \\
\hline A39 & $\begin{array}{l}\text { X-760 chemical engineering facility, } \\
\text { northwest corner of outside wall }\end{array}$ & NA \\
\hline \multicolumn{3}{|c|}{ Off-site (fence-line) air-sampling stations } \\
\hline A3 (S) & South Access Rd., south of DOE property line & SSW \\
\hline A8 (NW) & $\begin{array}{l}\text { DOE power pole } 74 \text { on dirt patrol road starting } \\
\text { north of X-735 }\end{array}$ & NW \\
\hline A9 (SW) & Southwest Access Rd. and Old Rt. 23 & SW \\
\hline $\mathrm{A} 12(\mathrm{E})$ & McCorkle Rd. north of East Access Rd. & ENE \\
\hline $\mathrm{A} 15(\mathrm{SE})$ & North end of Cemetery Rd. & SE \\
\hline A23 (NE) & Barlow Rd. and Taylor Hollow Rd. & NE \\
\hline $\mathrm{A} 24(\mathrm{~N})$ & North Access Rd. north of Shyville Rd. & $\mathrm{N}$ \\
\hline A29 (W) & U.S. Rt. 23 on near leg of old GAT sign & W \\
\hline \multicolumn{3}{|c|}{ Off-site air-sampling stations } \\
\hline A6 PK & $\begin{array}{l}\text { DOE power pole } 6 \text { on access road to X-608 pump } \\
\text { house in Piketon }\end{array}$ & NNW \\
\hline $\mathrm{A} 28 \mathrm{CC}$ & Mt. Zion Church on Camp Creek Rd. & SW \\
\hline A37 OT & AT\&T booster station on Mt. Hope Rd. west of Otway & SW \\
\hline
\end{tabular}


Table 2.9. Quarterly external gamma radiation levels $(\mu \mathrm{rad} / \mathrm{h})$ for 1990

\begin{tabular}{|c|c|c|c|c|c|}
\hline $\begin{array}{c}\text { Date } \\
\text { (Series No.) }\end{array}$ & $\begin{array}{c}\text { Jan-Mar } \\
486\end{array}$ & $\begin{array}{l}\text { Apr-Jun } \\
506-3\end{array}$ & $\begin{array}{c}\text { Jul-Sept } \\
506-4\end{array}$ & $\begin{array}{c}\text { Oct-Dec } \\
506-3\end{array}$ & $\begin{array}{c}\text { Annual } \\
\text { dosages } \\
\text { (mrem) }\end{array}$ \\
\hline \multicolumn{6}{|c|}{ On-site } \\
\hline $\begin{array}{l}\text { X-104 } \\
\text { X-230-J2 } \\
\text { X-611 } \\
\text { X-7725 } \\
862 \\
906 \\
933 \\
\quad \text { Mean } \\
\quad \text { Standard deviations }\end{array}$ & $\begin{array}{r}11.1 \\
10.2 \\
10.0 \\
10.0 \\
12.7 \\
8.8 \\
12.2 \\
10.9 \\
1.2\end{array}$ & $\begin{array}{r}9.4 \\
11.1 \\
10.3 \\
11.5 \\
12.1 \\
9.1 \\
12.6 \\
10.9 \\
1.2\end{array}$ & $\begin{array}{r}10.0 \\
9.9 \\
10.9 \\
10.8 \\
12.5 \\
10.3 \\
13.1 \\
11.1 \\
1.2\end{array}$ & $\begin{array}{r}8.7 \\
8.8 \\
10.8 \\
9.1 \\
10.0 \\
7.5 \\
11.4 \\
9.5 \\
1.2\end{array}$ & 93 \\
\hline $874^{\circ}$ & 128.2 & 131.6 & 116.5 & 125 & 0.55 \\
\hline \multicolumn{6}{|c|}{ Boundary line } \\
\hline $\begin{array}{l}\text { A3 } \\
\text { A8 } \\
\text { A9 } \\
\text { A12 } \\
\text { A15 } \\
\text { Ai23 } \\
\text { A24 } \\
\text { A:9 } \\
\text { Mean } \\
\text { Standard deviations }\end{array}$ & $\begin{array}{r}8.9 \\
11.0 \\
8.6 \\
10.4 \\
10.3 \\
10.9 \\
9.2 \\
8.8 \\
9.8 \\
0.9\end{array}$ & $\begin{array}{r}10.2 \\
11.5 \\
9.5 \\
9.1 \\
12.0 \\
9.8 \\
11.1 \\
9.3 \\
9.3 \\
10.3 \\
1.0\end{array}$ & $\begin{array}{r}9.2 \\
12.7 \\
10.1 \\
9.3 \\
12.8 \\
9.8 \\
9.8 \\
10.6 \\
8.8 \\
10.4 \\
1.4\end{array}$ & $\begin{array}{r}8.9 \\
11.4 \\
9.6 \\
6.8 \\
9.2 \\
7.7 \\
8.0 \\
7.1 \\
8.6 \\
1.4\end{array}$ & 86 \\
\hline \multicolumn{6}{|c|}{ Off-site } \\
\hline $\begin{array}{l}\text { A6 } \\
\text { A28 } \\
\text { Control } \\
\text { Reference }\end{array}$ & $\begin{array}{l}9.9 \\
8.9 \\
0.2 \\
5.13 \%\end{array}$ & $\begin{array}{c}11.3 \\
9.2 \\
1.0 \\
33.0 \%\end{array}$ & $\begin{array}{l}10.0 \\
9.6 \\
0.0 \\
2.97 \%\end{array}$ & $\begin{array}{c}8.6 \\
7.2 \\
1.1 \\
15.3 \%\end{array}$ & $\begin{array}{l}87 \\
76\end{array}$ \\
\hline
\end{tabular}

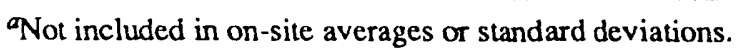


Table 2.10. Environmental TLD locations

\begin{tabular}{|c|c|c|}
\hline Designation & Location & Direction \\
\hline \multicolumn{3}{|c|}{ Reference and Consrol TLDs } \\
\hline $\mathrm{X}-100$ & $\begin{array}{l}\text { Administration Building } \\
\text { [Reference on air sampler (A40) weather hood] }\end{array}$ & NA \\
\hline$X-1000$ & $\begin{array}{l}\text { ES\&H Building } \\
\text { (Control in Environmental Control storeroom) }\end{array}$ & \\
\hline \multicolumn{3}{|c|}{ Site Group I (on or inside security fence) } \\
\hline $\mathrm{X}-104$ & Guard headquarters & $\mathrm{E}$ \\
\hline $\mathrm{X}-230-\mathrm{J} 2$ & South Holding Pond monitoring station (A38) & $S$ \\
\hline $\mathrm{X}-611$ & Water Treatment Plant (A36) & NE \\
\hline $\mathrm{X}-7725$ & $\begin{array}{l}\text { GCEP R/A Building (on security fence north } \\
\text { of vehicle portal) }\end{array}$ & SW \\
\hline 862 & Power pole 862 opposite Main (West) Access Rd. & W \\
\hline 874 & $\begin{array}{l}\text { Power pole } 874 \text { at NW comer of X-745C Tails } \\
\text { Storage Yard }\end{array}$ & NW \\
\hline 906 & Power pole 906 opposite North Access Rd. & $\mathrm{N}$ \\
\hline 933 & Power pole 933 opposite East Access Rd. & $\mathrm{E}$ \\
\hline \multicolumn{3}{|c|}{ Site Group II (on or near DOE property line) } \\
\hline 3 & $S$ air sampler (A3) on South Access Rd. & $\mathrm{S}$ \\
\hline 8 & NW air sampler (A8) at DOE power pole 74 & NW \\
\hline 9 & $\begin{array}{l}\text { SW air sampler (A9) at Southwest Access Rd. } \\
\text { and Old Rt. } 23 \text { (old location C) }\end{array}$ & SW \\
\hline 12 & E air sampler (A12) on McCorkle Rd & E \\
\hline 15 & $\begin{array}{l}\text { SE air sampler (A15) at north end of } \\
\text { Cemetery Rd. }\end{array}$ & SE \\
\hline 23 & $\begin{array}{l}\text { NE air sampler (A23) at Barlow Rd. and } \\
\text { Taylor Hollow Rd. (old location L) }\end{array}$ & NE \\
\hline 24 & $\begin{array}{l}\mathrm{N} \text { air sampler (A24) on North Access Rd. at } \\
\text { Shyville Rd. }\end{array}$ & $\mathrm{N}$ \\
\hline 29 & W air sampler (A29) on US Rt. 23 & W \\
\hline \multicolumn{3}{|c|}{ Off-site TLDs } \\
\hline 6 & $\begin{array}{l}\text { Piketon air sampler (A6) on access road to } \\
\text { X-608 Pump House in Piketon }\end{array}$ & $\mathrm{N}$ \\
\hline 28 & Camp Creek air sampler (A28) & SW \\
\hline
\end{tabular}


3. SURFACE WATER 
Table 3.1. NPDES chemical data summary

\begin{tabular}{|c|c|c|c|c|c|}
\hline \multirow{2}{*}{ Parameter } & \multicolumn{4}{|c|}{ Concentrations } & \multirow{2}{*}{$\begin{array}{l}\text { Number of } \\
\text { samples }\end{array}$} \\
\hline & Min & $\operatorname{Max}$ & Av & $\begin{array}{l}\text { Standard } \\
\text { deviation }\end{array}$ & \\
\hline \multicolumn{6}{|c|}{ NPDES 001} \\
\hline $\begin{array}{l}\text { Flow (Mgd) } \\
\text { Temp }\left({ }^{\circ} \mathrm{C}\right) \\
\text { pH (std. units) } \\
\text { TSS (mg/L) } \\
\text { Oil (mg/L) } \\
\mathrm{Cl}_{2}(\mathrm{mg} / \mathrm{L})\end{array}$ & $\begin{array}{l}0.510 \\
10 \\
7.3 \\
0.0 \\
0.0 \\
0.00\end{array}$ & $\begin{array}{l}3.050 \\
30 \\
8.6 \\
32.0 \\
7.9 \\
0.30\end{array}$ & $\begin{array}{c}1.699 \\
19.1 \\
8.0 \\
4.03 \\
0.38 \\
0.01\end{array}$ & $\begin{array}{l}0.523 \\
4.6 \\
\text { N/A } \\
5.00 \\
1.55 \\
0.04\end{array}$ & $\begin{array}{r}356 \\
52 \\
52 \\
52 \\
52 \\
51\end{array}$ \\
\hline \multicolumn{6}{|c|}{ NPDES 002} \\
\hline $\begin{array}{l}\text { Flow (Mgd) } \\
\text { pH (std. units) } \\
\text { TSS (mg/L) } \\
\text { Oil (mg/L) } \\
\mathrm{Cl}_{2}(\mathrm{mg} / \mathrm{L}) \\
\mathrm{Cu}(\mu \mathrm{g} / \mathrm{L}) \\
\mathrm{Fe}(\mu \mathrm{g} / \mathrm{L}) \\
\mathrm{Ni}(\mu \mathrm{g} / \mathrm{L}) \\
\mathrm{Zn}(\mu \mathrm{g} / \mathrm{L}) \\
\mathrm{As}(\mu \mathrm{g} / \mathrm{L}) \\
\mathrm{Mn}(\mu \mathrm{g} / \mathrm{L})\end{array}$ & $\begin{array}{c}0.014 \\
7.1 \\
0.0 \\
0.0 \\
0.00 \\
0 \\
220 \\
0 \\
0 \\
0 \\
40\end{array}$ & $\begin{array}{c}1.080 \\
9.0 \\
36.5 \\
7.6 \\
0.00 \\
40 \\
7,500 \\
40 \\
320 \\
50 \\
5,160\end{array}$ & $\begin{array}{c}0.665 \\
7.9 \\
8.64 \\
0.28 \\
0.00 \\
2.9 \\
1,046 \\
3.85 \\
52.69 \\
2.50 \\
421.2\end{array}$ & $\begin{array}{c}0.303 \\
\text { N/A } \\
7.50 \\
1.40 \\
\text { N/A } \\
8.7 \\
1,065 \\
10.95 \\
47.60 \\
8.52 \\
810.6\end{array}$ & $\begin{array}{r}348 \\
52 \\
50 \\
51 \\
50 \\
52 \\
52 \\
52 \\
52 \\
52 \\
52\end{array}$ \\
\hline \multicolumn{6}{|c|}{ NPDES 602} \\
\hline $\begin{array}{l}\text { Flow (Mgd) } \\
\text { pH (std. units) } \\
\text { TSS (mg/L) } \\
\mathrm{Cu}(\mu \mathrm{g} / \mathrm{L}) \\
\mathrm{Fe}(\mu \mathrm{g} / \mathrm{L}) \\
\mathrm{Ni}(\mu \mathrm{g} / \mathrm{L}) \\
\mathrm{Zn}(\mu \mathrm{g} / \mathrm{L}) \\
\mathrm{As}(\mu \mathrm{g} / \mathrm{L}) \\
\mathrm{Mn}(\mu \mathrm{g} / \mathrm{L})\end{array}$ & $\begin{array}{c}0.000 \\
7.3 \\
0.0 \\
0 \\
110 \\
0 \\
0 \\
0 \\
30\end{array}$ & $\begin{array}{c}0.144 \\
10.9 \\
18.0 \\
50 \\
3,780 \\
70 \\
370 \\
20 \\
210\end{array}$ & $\begin{array}{c}0.040 \\
8.6 \\
7.10 \\
5.8 \\
915 \\
32.5 \\
107 \\
0.4 \\
96.3\end{array}$ & $\begin{array}{c}0.035 \\
\text { N/A } \\
3.67 \\
12.5 \\
634 \\
20.7 \\
80 \\
2.7 \\
41.6\end{array}$ & $\begin{array}{r}364 \\
54 \\
52 \\
52 \\
52 \\
52 \\
52 \\
52 \\
52\end{array}$ \\
\hline \multicolumn{6}{|c|}{ NPDES 003} \\
\hline \begin{tabular}{l} 
Flow (Mgd) \\
pH (std. units) \\
TSS (mg/L) \\
$\mathrm{Cl}_{2}(\mathrm{mg} / \mathrm{L})$ \\
$\mathrm{Ni}(\mu \mathrm{g} / \mathrm{L})$ \\
$\mathrm{BOD}(\mathrm{mg} / \mathrm{L})$ \\
Coliform \\
\multicolumn{1}{c}{ (No./100 ml) }
\end{tabular} & $\begin{array}{l}0.093 \\
7.1 \\
0.0 \\
0.00 \\
0 \\
0.00 \\
0\end{array}$ & $\begin{array}{c}0.453 \\
9.2 \\
2.8 \\
1.06 \\
60 \\
6.64 \\
8,100\end{array}$ & $\begin{array}{l}0.234 \\
7.8 \\
0.77 \\
0.15 \\
7.3 \\
1.75 \\
193.3\end{array}$ & $\begin{array}{c}0.060 \\
\text { N/A } \\
0.86 \\
0.16 \\
14.2 \\
1.65 \\
1,120.7\end{array}$ & $\begin{array}{r}365 \\
53 \\
52 \\
50 \\
51 \\
52 \\
51\end{array}$ \\
\hline
\end{tabular}


Table 3.1 (Continued)

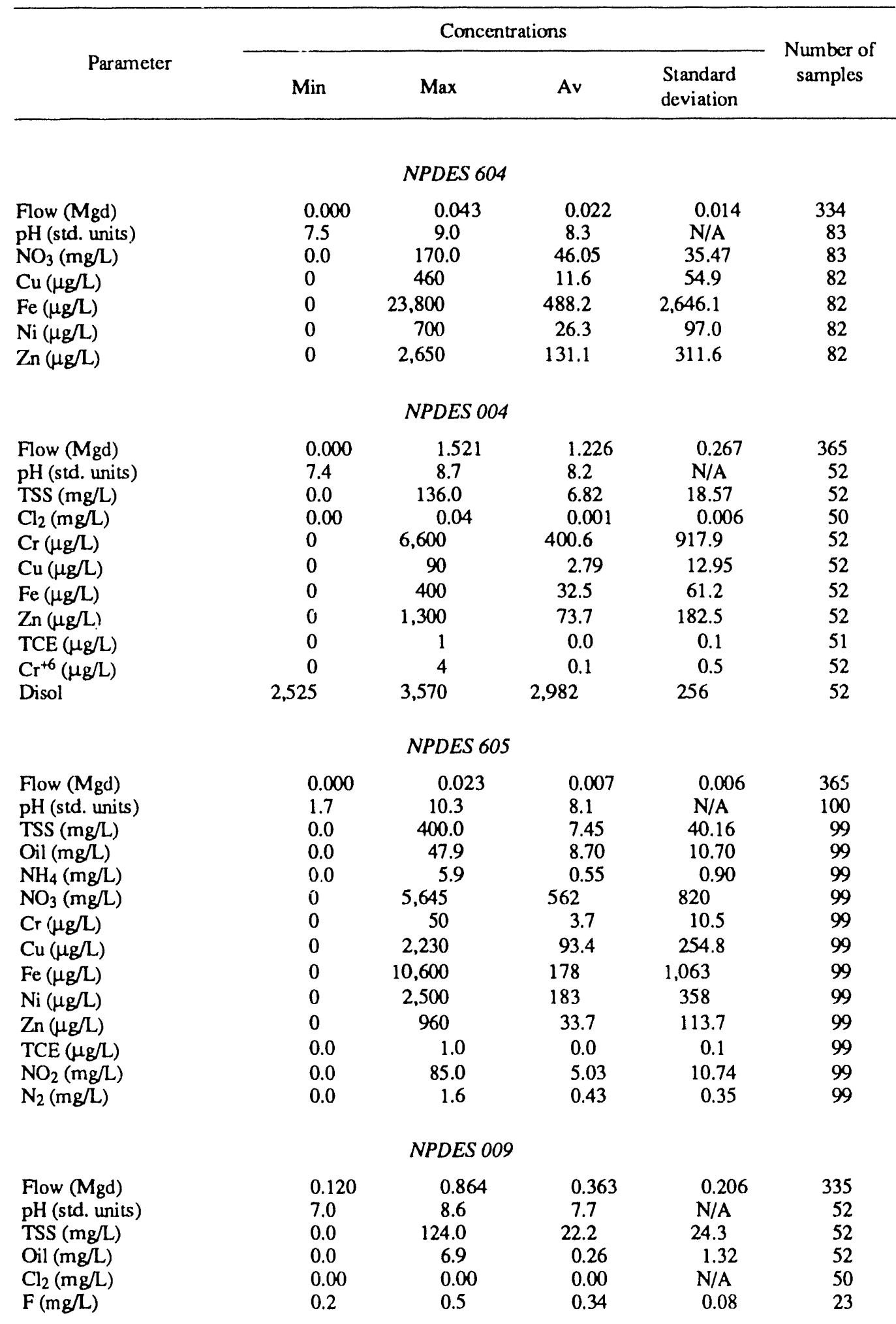


Table 3.1 (Continued)

\begin{tabular}{|c|c|c|c|c|c|}
\hline \multirow{2}{*}{ Parameter } & \multicolumn{4}{|c|}{ Concentrations } & \multirow{2}{*}{$\begin{array}{c}\text { Number of } \\
\text { samples }\end{array}$} \\
\hline & Min & $\operatorname{Max}$ & Av & $\begin{array}{l}\text { Standard } \\
\text { deviation }\end{array}$ & \\
\hline \multicolumn{6}{|c|}{ NPDES 010} \\
\hline $\begin{array}{l}\text { Flow (Mgd) } \\
\text { pH (std. units) } \\
\text { Oil (mg/L) }\end{array}$ & $\begin{array}{l}0.000 \\
7.1 \\
0.0\end{array}$ & $\begin{array}{l}0.650 \\
8.8 \\
6.4\end{array}$ & $\begin{array}{l}0.238 \\
7.7 \\
0.13\end{array}$ & $\begin{array}{l}0.171 \\
\mathrm{~N} / \mathrm{A} \\
0.91\end{array}$ & $\begin{array}{r}314 \\
50 \\
48\end{array}$ \\
\hline \multicolumn{6}{|c|}{ NPDES 011} \\
\hline $\begin{array}{l}\text { Flow (Mgd) } \\
\text { pH (std. units) } \\
\text { Oil (mg/L) }\end{array}$ & $\begin{array}{l}0.002 \\
2.9 \\
0.0\end{array}$ & $\begin{array}{l}0.782 \\
9.0 \\
7.2\end{array}$ & $\begin{array}{l}0.080 \\
7.7 \\
0.25\end{array}$ & $\begin{array}{l}0.081 \\
\mathrm{~N} / \mathrm{A} \\
1.23\end{array}$ & $\begin{array}{r}267 \\
52 \\
50\end{array}$ \\
\hline \multicolumn{6}{|c|}{ GCEP NPDES OOI } \\
\hline $\begin{array}{l}\text { Flow (Mgd) } \\
\text { pH (std. units) } \\
\text { TSS (mg/L) } \\
\text { Oil (mg/L) }\end{array}$ & $\begin{array}{l}0.000 \\
6.6 \\
7.6 \\
0.0\end{array}$ & $\begin{array}{c}0.551 \\
8.0 \\
360.0 \\
16.1\end{array}$ & $\begin{array}{c}0.007 \\
7.5 \\
82.31 \\
2.39\end{array}$ & $\begin{array}{c}0.047 \\
\text { N/A } \\
94.18 \\
5.61\end{array}$ & $\begin{array}{r}250 \\
15 \\
13 \\
13\end{array}$ \\
\hline \multicolumn{6}{|c|}{ GCEP NPDES 002} \\
\hline $\begin{array}{l}\text { Flow (Mgd) } \\
\text { pH (sid. units) } \\
\text { TSS (mg/L) } \\
\text { Oil (mg/L) }\end{array}$ & $\begin{array}{l}0.000 \\
6.9 \\
0.0 \\
0.0\end{array}$ & $\begin{array}{l}6.880 \\
8.4 \\
54.6 \\
19.2\end{array}$ & $\begin{array}{c}0.257 \\
7.9 \\
10.21 \\
0.60\end{array}$ & $\begin{array}{c}0.841 \\
\mathrm{~N} / \mathrm{A} \\
10.13 \\
2.87\end{array}$ & $\begin{array}{r}250 \\
210 \\
51 \\
50\end{array}$ \\
\hline \multicolumn{6}{|c|}{ GCEP NPDES 003} \\
\hline $\begin{array}{l}\text { Flow (Mgd) } \\
\text { pH (std. units) } \\
\text { TSS (mg/L) } \\
\text { Oil (mg/L) }\end{array}$ & $\begin{array}{l}0.000 \\
6.6 \\
7.6 \\
0.0\end{array}$ & $\begin{array}{c}0.551 \\
8.0 \\
360.0 \\
16.1\end{array}$ & $\begin{array}{c}0.007 \\
7.5 \\
82.31 \\
2.39\end{array}$ & $\begin{array}{c}0.047 \\
\text { N/A } \\
94.18 \\
5.61\end{array}$ & $\begin{array}{r}250 \\
15 \\
13 \\
13\end{array}$ \\
\hline
\end{tabular}


Table 3.2. 1990 Radiological data summary

\begin{tabular}{|c|c|c|c|c|c|}
\hline \multirow{2}{*}{ Parameter } & \multicolumn{3}{|c|}{ Concentration } & \multirow{2}{*}{$\begin{array}{l}\text { Standard } \\
\text { deviation }\end{array}$} & \multirow{2}{*}{$\begin{array}{c}\text { Number of } \\
\text { samples }\end{array}$} \\
\hline & $\operatorname{Max}$ & Min & Av & & \\
\hline \multicolumn{6}{|c|}{ NPDES 001} \\
\hline $\begin{array}{l}\mathrm{U}(\mathrm{mg} / \mathrm{L}) \\
\text { Alpha }(\mathrm{pCi} / \mathrm{L}) \\
{ }_{99} \mathrm{Tc}(p \mathrm{Ci} / \mathrm{L}) \\
\text { Beta }(\mathrm{pCi} / \mathrm{L})\end{array}$ & $\begin{array}{c}0.138 \\
1,314.0 \\
194 \\
198\end{array}$ & $\begin{array}{c}0.001 \\
9.0 \\
3 \\
-17\end{array}$ & $\begin{array}{c}0.012 \\
129.5 \\
56.9 \\
31.9\end{array}$ & $\begin{array}{c}0.023 \\
252.3 \\
29.0 \\
42.3\end{array}$ & $\begin{array}{l}52 \\
48 \\
50 \\
51\end{array}$ \\
\hline \multicolumn{6}{|c|}{ NPDES 002} \\
\hline $\begin{array}{l}\mathrm{U}(\mathrm{mg} / \mathrm{L}) \\
\text { Alpha }(\mathrm{pCi} / \mathrm{L}) \\
{ }_{99} \mathrm{Tc}(\mathrm{pCi} / \mathrm{L}) \\
\text { Beta (pCi/L) }\end{array}$ & $\begin{array}{l}0.005 \\
19.8 \\
43 \\
63\end{array}$ & $\begin{array}{l}<0.001 \\
-6.0 \\
-9 \\
-8\end{array}$ & $\begin{array}{c}<0.001 \\
3.61 \\
7.5 \\
8.6\end{array}$ & $\begin{array}{l}0.001 \\
3.75 \\
8.8 \\
10.5\end{array}$ & $\begin{array}{l}52 \\
52 \\
52 \\
52\end{array}$ \\
\hline \multicolumn{6}{|c|}{ NPDES 003} \\
\hline $\begin{array}{l}\mathrm{U}(\mathrm{mg} / \mathrm{L}) \\
\text { Alpha }(\mathrm{pCi} / \mathrm{L}) \\
{ }_{99} \mathrm{Tc}(\mathrm{pCi} / \mathrm{L}) \\
\text { Beta }(\mathrm{pCi} / \mathrm{L})\end{array}$ & $\begin{array}{l}\quad 0.044 \\
810.0 \\
765 \\
485\end{array}$ & $\begin{array}{c}0.001 \\
9.0 \\
4 \\
-12\end{array}$ & $\begin{array}{l}\quad 0.020 \\
200.4 \\
242.6 \\
109.2\end{array}$ & $\begin{array}{l}0.011 \\
149.5 \\
136.7 \\
114.7\end{array}$ & $\begin{array}{l}52 \\
51 \\
51 \\
51\end{array}$ \\
\hline \multicolumn{6}{|c|}{ NPDES 004} \\
\hline $\begin{array}{l}\mathrm{U}(\mathrm{mg} / \mathrm{L}) \\
\text { Alpha (pCi/L) } \\
{ }_{99} \mathrm{Tc}(\mathrm{pCi} / \mathrm{L}) \\
\text { Beta (pCi/L) }\end{array}$ & $\begin{array}{c}0.018 \\
95.0 \\
19,812 \\
8,941\end{array}$ & $\begin{array}{c}<0.001 \\
-14.0 \\
14 \\
34\end{array}$ & $\begin{array}{c}<0.002 \\
7.78 \\
649 \\
361\end{array}$ & 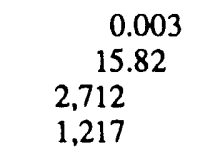 & $\begin{array}{l}52 \\
52 \\
52 \\
52\end{array}$ \\
\hline \multicolumn{6}{|c|}{ NPDES 009} \\
\hline $\begin{array}{l}\mathrm{U}(\mathrm{mg} / \mathrm{L}) \\
\text { Alpha (pCi/L) } \\
{ }_{99} \mathrm{Tc}(\mathrm{pCi} / \mathrm{L}) \\
\text { Beta }(\mathrm{pCi} / \mathrm{L})\end{array}$ & $\begin{array}{l}0.015 \\
19.4 \\
32 \\
38\end{array}$ & $\begin{array}{l}<0.002 \\
-3.0 \\
-2 \\
-6\end{array}$ & $\begin{array}{c}<0.009 \\
8.64 \\
7.6 \\
10.0\end{array}$ & $\begin{array}{l}0.003 \\
4.15 \\
6.5 \\
8.0\end{array}$ & $\begin{array}{l}51 \\
51 \\
51 \\
51\end{array}$ \\
\hline \multicolumn{6}{|c|}{ NPDES 010} \\
\hline $\begin{array}{l}\mathrm{U}(\mathrm{mg} / \mathrm{L}) \\
\text { Alpha }(\mathrm{pCi} / \mathrm{L}) \\
{ }_{99} \mathrm{Tc}(\mathrm{pCi} / \mathrm{L}) \\
\operatorname{Beta}(\mathrm{pCi} / \mathrm{L})\end{array}$ & $\begin{array}{l}0.018 \\
57.0 \\
40 \\
107\end{array}$ & $\begin{array}{l}0.001 \\
0.0 \\
-2 \\
-7\end{array}$ & $\begin{array}{l}0.008 \\
8.85 \\
6.0 \\
10.2\end{array}$ & $\begin{array}{c}0.004 \\
8.12 \\
6.4 \\
15.4\end{array}$ & $\begin{array}{l}51 \\
50 \\
50 \\
50\end{array}$ \\
\hline \multicolumn{6}{|c|}{ NPDES 011} \\
\hline $\begin{array}{l}\mathrm{U}(\mathrm{mg} / \mathrm{L}) \\
\text { Alpha (pCi/L) } \\
{ }_{99} \mathrm{Tc}(\mathrm{pCi} / \mathrm{L}) \\
\text { Beta (pCi/L) }\end{array}$ & $\begin{array}{l}0.024 \\
15.8 \\
20 \\
15\end{array}$ & $\begin{array}{l}<0.001 \\
-6.0 \\
-6 \\
-6\end{array}$ & $\begin{array}{l}<0.002 \\
2.63 \\
5.2 \\
4.5\end{array}$ & $\begin{array}{l}0.004 \\
3.47 \\
5.4 \\
4.9\end{array}$ & $\begin{array}{l}52 \\
51 \\
51 \\
51\end{array}$ \\
\hline \multicolumn{6}{|c|}{ NPDES 605} \\
\hline $\begin{array}{l}\mathrm{U}(\mathrm{mg} / \mathrm{L}) \\
\text { Alpha }(\mathrm{pCi} / \mathrm{L}) \\
{ }_{99} \mathrm{Tc}(\mathrm{pCi} / \mathrm{L}) \\
\text { Beta (pCi/L) }\end{array}$ & $\begin{array}{c}19.400 \\
180,079 \\
9,381,520 \\
10,841\end{array}$ & $\begin{array}{l}0.140 \\
990 \\
273 \\
84\end{array}$ & $\begin{array}{c}3.197 \\
22,338 \\
254,644 \\
1,998\end{array}$ & $\begin{array}{c}3.958 \\
32,657 \\
1,303,493 \\
2,380\end{array}$ & $\begin{array}{l}51 \\
51 \\
51 \\
41\end{array}$ \\
\hline
\end{tabular}


Table 3.2 (Continued)

\begin{tabular}{lccccc}
\hline & & Concentration & & Standard & Number of \\
Parameter & Max & Mir & Av & Aviation & samples
\end{tabular}

$\begin{array}{ll}\mathrm{U}(\mathrm{mg} / \mathrm{L}) & 0.002 \\ \mathrm{Alpha}(\mathrm{pCi} / \mathrm{L}) & 5.4 \\ { }_{99}^{\mathrm{Tc}}(\mathrm{pCi} / \mathrm{L}) & 15 \\ & 11\end{array}$

GCEP NPDES OOI

11

$\begin{array}{cc}-0.011 & <0.001 \\ 0.0 & 1.88 \\ 0 & 5.8 \\ -2 & 3.0\end{array}$

\section{GCEP NPDES 002}

U'(nig/L)

Alpha (pCi/L)

${ }^{99} \mathrm{Tc}(\mathrm{pCi} / \mathrm{L})$

Beta $(\mathrm{pCi} / \mathrm{L})$

0.002
14.4
10
25

$\mathrm{U}$ (mgL)

Alpha (pCi/L)

${ }^{99} \mathrm{Tc}(\mathrm{pCi} / \mathrm{L})$

Beta $\left(p r^{\prime} i / L\right)$

0.003
9.9
14
34

$\mathrm{U}(\mathrm{mg} / \mathrm{L})$

Alpha $(\mathrm{pCi} / \mathrm{L})$

${ }^{99} \mathrm{Tc}(\mathrm{pCi} / \mathrm{L})$

$\operatorname{Beta}(\mathrm{pCi} / \mathrm{L})$

0.012

93.6

53

77

$<0.001$
0.0
0
-5

$<0.001$

3.18

6.9

$\begin{array}{lr}0.000 & 11 \\ 4.13 & 9 \\ 3.4 & 9 \\ 8.9 & 9\end{array}$

\section{GCEP NPDES 003}

$\begin{array}{lccc}<0.001 & <0.002 & 0.001 & 5 \\ 2.0 & 5.97 & 3.23 & 5 \\ 1 & 6.4 & 4.5 & 5 \\ 2 & 15.4 & 10.6 & 5\end{array}$

$R W-7$

$\begin{array}{llll}0.001 & 0.004 & 0.002 & 11 \\ 4.1 & 31.41 & 23.06 & 11 \\ \hat{A} & 31.5 & 14.8 & 11 \\ 17 & 37.6 & 18.2 & 11\end{array}$

$R W-8$

$\mathrm{U}(\mathrm{mg} / \mathrm{L})$

Alpha (pCi/L)

${ }^{99} \mathrm{Tc}(\mathrm{pCi} / \mathrm{L})$

$\operatorname{Beta}(\mathrm{pCi} / \mathrm{L})$

0.046
644.0
64
110

0.001

9.9

14

o

0.007
72.52
32.8
42.4

0.007

102.8

42.4

21.0

$R W-12$

$1(\mathrm{mg} / \mathrm{L})$

Alpha $(p \mathrm{Ci} / \mathrm{L})$

${ }^{99} \mathrm{Tc}(\mathrm{pCi} / \mathrm{L})$

Beta $(\mathrm{pCi} / \mathrm{L})$

$<0.001$
1.0
17
25

$\mathrm{U}(\mathrm{mg} / \mathrm{L})$

Alpha (pCi/L)

${ }^{99} \mathrm{Tc}(\mathrm{pCi} / \mathrm{L})$

Beta $(\mathrm{pCi} / \mathrm{L})$

0.015
97.2
58
73

$<0.001$

$-2.0$

$-4$

$<0.001$

0.06

5.3

11.4

N/A
0.90
6.5
10.6

11

11

$-5$

RW-S

$<0.001$
-1.0
0
-6

$<0.002$

58

11.2

$8.1^{\circ}$

73

15.7

20.9

$R W \cdot 13$

$\mathrm{U}(\mathrm{mg} / \mathrm{L})$

Alpha (pCi/L)

${ }^{99} \mathrm{Tc}(\mathrm{pCi} / \mathrm{L})$

$\operatorname{Beta}(\mathrm{pCi} / \mathrm{L})$

0.011
$7 ? .0$
45
61

$<0.003$

21.58

21.9

23.7

$\begin{array}{ll}0.002 & 11 \\ 19.17 & 11 \\ 12.0 & 11 \\ 16.8 & 11\end{array}$


Table 3.2 (Continued)

\begin{tabular}{|c|c|c|c|c|c|}
\hline \multirow{2}{*}{ Parameter } & \multicolumn{3}{|c|}{ Concentration } & \multirow{2}{*}{$\begin{array}{l}\text { Standard } \\
\text { deviation }\end{array}$} & \multirow{2}{*}{$\begin{array}{c}\text { Number of } \\
\text { samples }\end{array}$} \\
\hline & $\operatorname{Max}$ & Min & Av & & \\
\hline \multicolumn{6}{|c|}{$R W-2$} \\
\hline $\begin{array}{l}U(\mathrm{mg} / \mathrm{L}) \\
\text { Alpha }(\mathrm{pCi} / \mathrm{L}) \\
{ }^{99} \mathrm{Tc}(\mathrm{pCi} / \mathrm{L}) \\
\text { Beta }(\mathrm{pCi} / \mathrm{L})\end{array}$ & $\begin{array}{l}0.001 \\
7.2 \\
13 \\
11\end{array}$ & $\begin{array}{l}<0.001 \\
-1.0 \\
3 \\
-8\end{array}$ & $\begin{array}{c}<0.001 \\
1.46 \\
7.0 \\
3.5\end{array}$ & $\begin{array}{l}\text { N/A } \\
2.11 \\
3.5 \\
5.3\end{array}$ & $\begin{array}{l}11 \\
11 \\
11 \\
11\end{array}$ \\
\hline \multicolumn{6}{|c|}{$R W-3$} \\
\hline $\begin{array}{l}\mathrm{U}(\mathrm{mg} / \mathrm{L}) \\
\text { Alpha (pCi/L) } \\
{ }_{99} \mathrm{Tc}(\mathrm{pCi} / \mathrm{L}) \\
\text { Beta (pCi/L) }\end{array}$ & $\begin{array}{l}0.002 \\
10.0 \\
18 \\
16\end{array}$ & $\begin{array}{l}<0.001 \\
-1.0 \\
-3 \\
-4\end{array}$ & $\begin{array}{c}<0.001 \\
3.51 \\
7.6 \\
4.7\end{array}$ & $\begin{array}{l}0.000 \\
2.82 \\
5.7 \\
6.5\end{array}$ & $\begin{array}{l}11 \\
11 \\
11 \\
11\end{array}$ \\
\hline \multicolumn{6}{|c|}{$R W-33$} \\
\hline $\begin{array}{l}U(\mathrm{mg} / \mathrm{L}) \\
\text { Alpha }(p \mathrm{pi} / \mathrm{L}) \\
{ }_{99} \mathrm{Tc}(\mathrm{pCi} / \mathrm{L}) \\
\text { Beta }(p \mathrm{Ci} / \mathrm{L})\end{array}$ & $\begin{array}{l}0.003 \\
2.7 \\
12 \\
10\end{array}$ & $\begin{array}{l}<0.001 \\
-2.0 \\
-1 \\
-8\end{array}$ & $\begin{array}{c}<0.001 \\
0.28 \\
5.8 \\
4.5\end{array}$ & $\begin{array}{l}0.000 \\
1.12 \\
4.4 \\
5.1\end{array}$ & $\begin{array}{l}11 \\
11 \\
11 \\
11\end{array}$ \\
\hline \multicolumn{6}{|c|}{$R W-I$} \\
\hline $\begin{array}{l}\mathrm{U}(\mathrm{mg} / \mathrm{L}) \\
\text { Alpha }(\mathrm{pCi} / \mathrm{L}) \\
{ }^{99} \mathrm{Tc}(\mathrm{pCi} / \mathrm{L}) \\
\text { Beta }(\mathrm{pCi} / \mathrm{L})\end{array}$ & $\begin{array}{l}0.005 \\
32 \\
99 \\
24\end{array}$ & $\begin{array}{l}<0.001 \\
-3 \\
-6 \\
-8\end{array}$ & $\begin{array}{c}<0.002 \\
3.1 \\
7.7 \\
6.4\end{array}$ & $\begin{array}{c}0.001 \\
4.7 \\
14.8 \\
5.6\end{array}$ & $\begin{array}{l}50 \\
50 \\
50 \\
50\end{array}$ \\
\hline \multicolumn{6}{|c|}{$R W-6$} \\
\hline $\begin{array}{l}\mathrm{U}(\mathrm{mg} / \mathrm{L}) \\
\text { Alpha }(p \mathrm{Ci} / \mathrm{L}) \\
{ }_{99} \mathrm{Tc}(\mathrm{pCi} / \mathrm{L}) \\
\text { Beta }(p C i / L)\end{array}$ & $\begin{array}{l}0.004 \\
36.0 \\
31 \\
24\end{array}$ & $\begin{array}{l}<0.001 \\
-1.0 \\
-4 \\
-8\end{array}$ & $\begin{array}{c}<0.001 \\
4.50 \\
6.4 \\
7.0\end{array}$ & $\begin{array}{l}0.000 \\
6.63 \\
6.7 \\
6.5\end{array}$ & $\begin{array}{l}50 \\
50 \\
50 \\
50\end{array}$ \\
\hline
\end{tabular}


4. GROUNDWATER 
Table 4.1. Monitoring at well field X701B for radionuclide parameters

\begin{tabular}{|c|c|c|c|c|c|c|}
\hline \multirow{2}{*}{ Well } & \multirow{2}{*}{ Parameter } & \multicolumn{3}{|c|}{ Concentration } & \multirow{2}{*}{$\begin{array}{l}\text { Standard } \\
\text { deviation }\end{array}$} & \multirow{2}{*}{ GWQA $^{a}$} \\
\hline & & Min & $\operatorname{Max}$ & Mean & & \\
\hline \multicolumn{7}{|c|}{ Gallia plume wells } \\
\hline X701-10G & $\begin{array}{l}\text { Technetium }(\mathrm{pCi} / \mathrm{L}) \\
\text { Gross alpha }(\mathrm{pCi} / \mathrm{L}) \\
\text { Gross beta }(\mathrm{pCi} / \mathrm{L}) \\
\text { Uranium (mg/L) }\end{array}$ & $\begin{array}{l}26.0 \\
17.0 \\
53.0 \\
0.026\end{array}$ & $\begin{array}{l}45.0 \\
166.0 \\
148.0 \\
0.930\end{array}$ & $\begin{array}{c}35.0 \\
94.5 \\
111.5 \\
0.370\end{array}$ & $\begin{array}{l}70.1 \\
41.7 \\
0.490\end{array}$ & $\begin{array}{c}18.0 \\
142.0 \\
82.0 \\
0.1350\end{array}$ \\
\hline$X 601-14 G$ & $\begin{array}{l}\text { Technetium }(\mathrm{pCi} / \mathrm{L}) \\
\text { Gross alpha }(\mathrm{pCi} / \mathrm{L}) \\
\text { Gross beta }(\mathrm{pCi} / \mathrm{L}) \\
\text { Uranium }(\mathrm{mg} / \mathrm{L})\end{array}$ & $\begin{array}{l}176.0 \\
12.0 \\
97.0 \\
0.002\end{array}$ & $\begin{array}{c}885.0 \\
70.0 \\
825.0 \\
0.033\end{array}$ & $\begin{array}{c}461.7 \\
44.5 \\
372.5 \\
0.024\end{array}$ & $\begin{array}{l}27.3 \\
322.8 \\
0.008\end{array}$ & $\begin{array}{c}825.0 \\
20.0 \\
563.0 \\
0.003\end{array}$ \\
\hline$X 701-24 G$ & $\begin{array}{l}\text { Technetium }(\mathrm{pCi} / \mathrm{L}) \\
\text { Gross alpha }(\mathrm{pCi} / \mathrm{L}) \\
\text { Gross beta }(\mathrm{pCi} / \mathrm{L}) \\
\text { Uranium }(\mathrm{mg} / \mathrm{L})\end{array}$ & $\begin{array}{c}110.0 \\
14.0 \\
82.0 \\
0.002\end{array}$ & $\begin{array}{c}131.0 \\
51.0 \\
154.0 \\
0.007\end{array}$ & $\begin{array}{c}120.5 \\
27.5 \\
105.8 \\
0.0048\end{array}$ & $\begin{array}{l}76.8 \\
32.8 \\
0.0021\end{array}$ & $\begin{array}{c}110.0 \\
23.0 \\
133.0 \\
0.007\end{array}$ \\
\hline \multicolumn{7}{|c|}{ Gallia fringe wells } \\
\hline$X 701-15 G$ & $\begin{array}{l}\text { Technetium }(\mathrm{pCi} / \mathrm{L}) \\
\text { Gross alpha }(\mathrm{pCi} / \mathrm{L}) \\
\text { Gross beta }(\mathrm{pCi} / \mathrm{L}) \\
\text { Uranium }(\mathrm{mg} / \mathrm{L})\end{array}$ & $\begin{array}{l}4.0 \\
2.0 \\
6.0 \\
0.003\end{array}$ & $\begin{array}{l}5.0 \\
35.0 \\
38.0 \\
0.012\end{array}$ & $\begin{array}{l}4.5 \\
20.0 \\
18.0 \\
0.007\end{array}$ & $\begin{array}{l}13.7 \\
13.9 \\
0.004\end{array}$ & $\begin{array}{l}25.0 \\
26.0 \\
26.0\end{array}$ \\
\hline$X 701-16$ & $\begin{array}{l}\text { Technetium }(\mathrm{pCi} / \mathrm{L}) \\
\text { Gross alpha }(\mathrm{pCi} / \mathrm{L}) \\
\text { Gross beta }(\mathrm{pCi} / \mathrm{L}) \\
\text { Uranium }(\mathrm{mg} / \mathrm{L})\end{array}$ & $\begin{array}{l}1.0 \\
18.0 \\
18.0 \\
0.007\end{array}$ & $\begin{array}{l}10.0 \\
46.0 \\
66.0 \\
0.026\end{array}$ & $\begin{array}{l}6.7 \\
37.5 \\
35.0 \\
0.0130\end{array}$ & $\begin{array}{l}13.3 \\
21.2 \\
0.009\end{array}$ & $\begin{array}{l}25.0 \\
26.0 \\
33.0 \\
0.024\end{array}$ \\
\hline$\times 701-19$ & $\begin{array}{l}\text { Technetium }(\mathrm{pCi} / \mathrm{L}) \\
\text { Gross alpha }(\mathrm{pCi} / \mathrm{L}) \\
\text { Gross beta }(\mathrm{pCi} / \mathrm{L}) \\
\text { Uranium }(\mathrm{mg} / \mathrm{L})\end{array}$ & $\begin{array}{c}6.0 \\
8.0 \\
9.0 \\
<0.002\end{array}$ & $\begin{array}{c}7.0 \\
27.0 \\
237.0 \\
0.016\end{array}$ & $\begin{array}{l}6.5 \\
20.0 \\
90.7 \\
0.008\end{array}$ & 0.008 & $\begin{array}{l}25.0 \\
20.0 \\
90.0 \\
0.007\end{array}$ \\
\hline$X 701-21 G$ & $\begin{array}{l}\text { Technetium }(\mathrm{pCi} / \mathrm{L}) \\
\text { Gross alpha }(\mathrm{pCi} / \mathrm{L}) \\
\text { Gross beta }(\mathrm{pCi} / \mathrm{L}) \\
\text { Uranium }(\mathrm{mg} / \mathrm{L})\end{array}$ & $\begin{array}{c}20.0 \\
5.0 \\
23.0 \\
<0.002\end{array}$ & $\begin{array}{l}35.0 \\
45.0 \\
54.0 \\
0.016\end{array}$ & $\begin{array}{l}29.7 \\
23.8 \\
35.2 \\
0.007\end{array}$ & $\begin{array}{l}16.5 \\
14.4 \\
0.006\end{array}$ & $\begin{array}{c}9.0 \\
13.0 \\
34.0 \\
0.011\end{array}$ \\
\hline X701-30G & $\begin{array}{l}\text { Technetium }(\mathrm{pCi} / \mathrm{L}) \\
\text { Gross alpha }(\mathrm{pCi} / \mathrm{L}) \\
\text { Gross beta }(\mathrm{pCi} / \mathrm{L}) \\
\text { Uranium (mg/L) }\end{array}$ & $\begin{array}{l}4.0 \\
-1.0 \\
9.0 \\
0.001\end{array}$ & $\begin{array}{c}14.0 \\
8.0 \\
45.0 \\
0.003\end{array}$ & $\begin{array}{c}8.7 \\
2.8 \\
19.5 \\
0.002\end{array}$ & $\begin{array}{l}3.9 \\
17.1 \\
0.001\end{array}$ & $\begin{array}{c}15.0 \\
4.0 \\
60.0 \\
0.002\end{array}$ \\
\hline$X 701-32 G$ & $\begin{array}{l}\text { Technetium }(\mathrm{pCi} / \mathrm{L}) \\
\text { Gross alpha }(\mathrm{pCi} / \mathrm{L}) \\
\text { Gross beta }(\mathrm{pCi} / \mathrm{L}) \\
\text { Uranium }(\mathrm{mg} / \mathrm{L})\end{array}$ & $\begin{array}{l}4.0 \\
-1.0 \\
4.0 \\
0.001\end{array}$ & $\begin{array}{c}5.0 \\
14.0 \\
17.0 \\
0.003\end{array}$ & $\begin{array}{l}4.7 \\
8.3 \\
8.3 \\
0.002\end{array}$ & $\begin{array}{l}6.4 \\
6.0 \\
0.001\end{array}$ & $\begin{array}{l}\mathrm{ND}^{b} \\
\mathrm{ND} \\
\mathrm{ND} \\
\mathrm{ND}\end{array}$ \\
\hline $\mathrm{X} 701 \cdot \mathrm{BW} 1$ & $\begin{array}{l}\text { Technetium }(\mathrm{pCi} / \mathrm{L}) \\
\text { Gross alpha }(\mathrm{pCi} / \mathrm{L}) \\
\text { Gross beta }(\mathrm{pCi} / \mathrm{L}) \\
\text { Uranium (mg/L) }\end{array}$ & $\begin{array}{c}4.0 \\
7.0 \\
10.0 \\
0.003\end{array}$ & $\begin{array}{c}7.0 \\
16.0 \\
38.0 \\
0.204\end{array}$ & $\begin{array}{l}5.7 \\
12.3 \\
22.7 \\
0.007\end{array}$ & 0.093 & $\begin{array}{l}\text { ND } \\
\text { ND } \\
\text { ND } \\
\text { ND }\end{array}$ \\
\hline
\end{tabular}


Table 4.1 (Continued)

\begin{tabular}{|c|c|c|c|c|c|c|}
\hline \multirow{2}{*}{ Well } & \multirow{2}{*}{ Parameter } & \multicolumn{3}{|c|}{ Concentration } & \multirow{2}{*}{$\begin{array}{l}\text { Standard } \\
\text { deviation }\end{array}$} & \multirow{2}{*}{$\mathrm{GWQA}^{a}$} \\
\hline & & Min & $\operatorname{Max}$ & Mean & & \\
\hline \multicolumn{7}{|c|}{ Gallia fringe wells } \\
\hline X701-BW4 & $\begin{array}{l}\text { Technetium }(p \mathrm{Ci} / \mathrm{L}) \\
\text { Gross alpha }(\mathrm{pCi} / \mathrm{L}) \\
\text { Gross beta }(\mathrm{pCi} / \mathrm{L}) \\
\text { Uranium }(\mathrm{mg} / \mathrm{L})\end{array}$ & $\begin{array}{l}9.0 \\
-4.0 \\
10.0 \\
<0.001\end{array}$ & $\begin{array}{c}16.0 \\
1060.0^{c} \\
1253.0^{d} \\
0.006\end{array}$ & $\begin{array}{l}12.5 \\
357.0 \\
429.7 \\
0.003\end{array}$ & & $\begin{array}{l}\text { ND } \\
\text { ND } \\
\text { ND } \\
\text { ND }\end{array}$ \\
\hline \multicolumn{7}{|c|}{ Gallia downgradient wells } \\
\hline$X 701-23 G$ & $\begin{array}{l}\text { Technetium }(\mathrm{pCi} / \mathrm{L}) \\
\text { Gross alpha }(\mathrm{pCi} / \mathrm{L}) \\
\text { Gross beta }(\mathrm{pCi} / \mathrm{L}) \\
\text { Uranium }(\mu \mathrm{g} / \mathrm{L})\end{array}$ & $\begin{array}{l}0.0 \\
-2.0 \\
-5.0 \\
0.001\end{array}$ & $\begin{array}{c}4.0 \\
10.0 \\
10.0 \\
0.004\end{array}$ & $\begin{array}{l}2.0 \\
5.8 \\
5.5 \\
0.003\end{array}$ & $\begin{array}{l}5.3 \\
7.0 \\
0.002\end{array}$ & $\begin{array}{c}25.0 \\
5.0 \\
18.0 \\
0.002\end{array}$ \\
\hline$X 701-25$ & $\begin{array}{l}\text { Technetium }(p C i / L) \\
\text { Gross alpha }(p C i / L) \\
\text { Gross beta }(p C i / L) \\
\text { Uranium }(\mu \mathrm{g} / \mathrm{L})\end{array}$ & $\begin{array}{c}-3.0 \\
0.0 \\
-11.0 \\
0.001\end{array}$ & $\begin{array}{l}2.0 \\
14.0 \\
15.0 \\
0.004\end{array}$ & $\begin{array}{l}0.0 \\
4.8 \\
4.5 \\
0.003\end{array}$ & $\begin{array}{c}6.4 \\
11.1 \\
0.001\end{array}$ & $\begin{array}{l}25.0 \\
30.0 \\
60.0 \\
0.003\end{array}$ \\
\hline$x 701-31$ & $\begin{array}{l}\text { Technetium }(p C i / L) \\
\text { Gross alpha }(p C i / L) \\
\text { Gross beta }(p C i / L) \\
\text { Uranium }(\mu \mathrm{g} / \mathrm{L})\end{array}$ & $\begin{array}{l}3.0 \\
-1.0 \\
-2.0 \\
0.0010\end{array}$ & $\begin{array}{c}14.0 \\
6.0 \\
15.0 \\
0.0020\end{array}$ & $\begin{array}{l}6.7 \\
1.8 \\
5.3 \\
0.0018\end{array}$ & $\begin{array}{c}3.4 \\
10.8 \\
0.0005\end{array}$ & $\begin{array}{l}2.0 \\
1.0 \\
8.0 \\
0.002\end{array}$ \\
\hline$\times 701-32$ & $\begin{array}{l}\text { Technetium }(p C i / L) \\
\text { Gross alpha }(p C i / L) \\
\text { Gross beta }(p C i / L) \\
\text { Uranium }(\mu \mathrm{g} / \mathrm{L})\end{array}$ & $\begin{array}{c}4.0 \\
-1.0 \\
4.0 \\
0.001\end{array}$ & $\begin{array}{c}5.0 \\
14.0 \\
17.0 \\
0.003\end{array}$ & $\begin{array}{l}4.7 \\
8.3 \\
8.3 \\
0.002\end{array}$ & $\begin{array}{l}6.4 \\
6.0 \\
0.001\end{array}$ & $\begin{array}{l}\text { ND } \\
\text { ND } \\
\text { ND } \\
\text { ND }\end{array}$ \\
\hline$\times 701-38$ & $\begin{array}{l}\text { Technetium }(\mathrm{pCi} / \mathrm{L}) \\
\text { Gross alpha }(\mathrm{pCi} / \mathrm{L}) \\
\text { Gross beta }(\mathrm{pCi} / \mathrm{L}) \\
\text { Uranium }(\mu \mathrm{g} / \mathrm{L})\end{array}$ & $\begin{array}{c}4.0 \\
9.0 \\
13.0 \\
0.002\end{array}$ & $\begin{array}{c}8.0 \\
34.0 \\
45.0 \\
0.024\end{array}$ & $\begin{array}{c}6.0 \\
21.8 \\
26.0 \\
0.009\end{array}$ & $\begin{array}{c}12.1 \\
13.9 \\
0.010\end{array}$ & $\begin{array}{c}25.0 \\
97.0 \\
74.0 \\
0.050\end{array}$ \\
\hline$\times 701-48$ & $\begin{array}{l}\text { Technetium }(\mathrm{pCi} / \mathrm{L}) \\
\text { Gross alpha }(\mathrm{pCi} / \mathrm{L}) \\
\text { Gross beta }(\mathrm{pCi} / \mathrm{L}) \\
\text { Uranium }(\mu \mathrm{g} / \mathrm{L})\end{array}$ & $\begin{array}{c}-1.0 \\
7.0 \\
27.0 \\
0.006\end{array}$ & $\begin{array}{l}13.0 \\
53.0 \\
62.0 \\
0.016\end{array}$ & $\begin{array}{c}6.0 \\
21.5 \\
39.5 \\
0.009\end{array}$ & $\begin{array}{l}21.2 \\
16.3 \\
0.005\end{array}$ & $\begin{array}{c}25.0 \\
59.0 \\
54.0 \\
0.03\end{array}$ \\
\hline$\times 701-49$ & $\begin{array}{l}\text { Technetium }(\mathrm{pCi} / \mathrm{L}) \\
\text { Gross alpha }(\mathrm{pCi} / \mathrm{L}) \\
\text { Gross beta }(\mathrm{pCi} / \mathrm{L}) \\
\text { Uranium }(\mu \mathrm{g} / \mathrm{L})\end{array}$ & $\begin{array}{l}4.0 \\
3.0 \\
1.0 \\
0.002\end{array}$ & $\begin{array}{c}8.0 \\
90.0 \\
106.0 \\
0.074\end{array}$ & $\begin{array}{c}5.3 \\
36.5 \\
36.2 \\
0.023\end{array}$ & $\begin{array}{l}37.5 \\
48.4 \\
0.034\end{array}$ & $\begin{array}{l}\text { ND } \\
\text { ND } \\
\text { ND } \\
\text { ND }\end{array}$ \\
\hline & & & a wells & & & \\
\hline$\times 701-50 \mathrm{~B}$ & $\begin{array}{l}\text { Technetium (pCi/L) } \\
\text { Gross alpha }(\mathrm{pCi} / \mathrm{L}) \\
\text { Gross beta }(\mathrm{pCi} / \mathrm{L}) \\
\text { Uranium }(\mu \mathrm{g} / \mathrm{L})\end{array}$ & $\begin{array}{c}4.0 \\
67.0 \\
51.0 \\
0.006\end{array}$ & $\begin{array}{c}17.0 \\
229.0 \\
125.0 \\
0.013\end{array}$ & $\begin{array}{c}9.7 \\
137.0 \\
130.0 \\
0.010\end{array}$ & 0.003 & $\begin{array}{l}25.0 \\
62.0 \\
28.0 \\
0.018\end{array}$ \\
\hline
\end{tabular}


Table 4.1 (Continued)

\begin{tabular}{|c|c|c|c|c|c|c|}
\hline \multirow{2}{*}{ Well } & \multirow{2}{*}{ Parameter } & \multicolumn{3}{|c|}{ Concentration } & \multirow{2}{*}{$\begin{array}{l}\text { Standard } \\
\text { deviation }\end{array}$} & \multirow{2}{*}{ GWQA $^{a}$} \\
\hline & & Min & $\operatorname{Max}$ & Mean & & \\
\hline \multicolumn{7}{|c|}{ Berea wells } \\
\hline X701-58 & $\begin{array}{l}\text { Technetium }(\mathrm{pCi} / \mathrm{L}) \\
\text { Gross alpha }(\mathrm{pCi} / \mathrm{L}) \\
\text { Gross beta }(\mathrm{pCi} / \mathrm{L}) \\
\text { Uranium }(\mu \mathrm{g} / \mathrm{L})\end{array}$ & $\begin{array}{l}-4.0 \\
25.0 \\
41.0 \\
0.001\end{array}$ & $\begin{array}{l}4.0 \\
77.0 \\
57.0 \\
0.017\end{array}$ & $\begin{array}{l}0.0 \\
46.0 \\
46.0 \\
0.010\end{array}$ & $\begin{array}{l}23.2 \\
8.1 \\
0.007\end{array}$ & $\begin{array}{l}25.0 \\
36.0 \\
10.0 \\
0.016\end{array}$ \\
\hline$\times 701-61$ & $\begin{array}{l}\text { Technetium }(p C i / L) \\
\text { Gross alpha }(p C i / L) \\
\text { Gross beta }(p C i / L) \\
\text { Uranium }(\mu \mathrm{g} / L)\end{array}$ & $\begin{array}{c}1.0 \\
43.0 \\
48.0 \\
0.006\end{array}$ & $\begin{array}{c}6.0 \\
191.0 \\
122.0 \\
0.028\end{array}$ & $\begin{array}{c}3.5 \\
100.2 \\
90.3 \\
0.014\end{array}$ & $\begin{array}{l}68.2 \\
36.3 \\
0.010\end{array}$ & $\begin{array}{c}9.0 \\
78.0 \\
83.0 \\
0.044\end{array}$ \\
\hline
\end{tabular}

${ }^{a}$ Groundwater quality assessment.

${ }^{b} \mathrm{ND}=$ no data.

${ }^{c}$ High activity level believed to be anomolous based on the uranium concentration; resampling and reanalysis being performed.

${ }^{d}$ High activity level believed to be anomolous based on the technetium concentration; resampling and reanalysis being performed. 
Table 4.2. Monitoring at well field X701B for volatile organic compounds [ppb $(\mu \mathrm{g} / \mathrm{L})$ ]

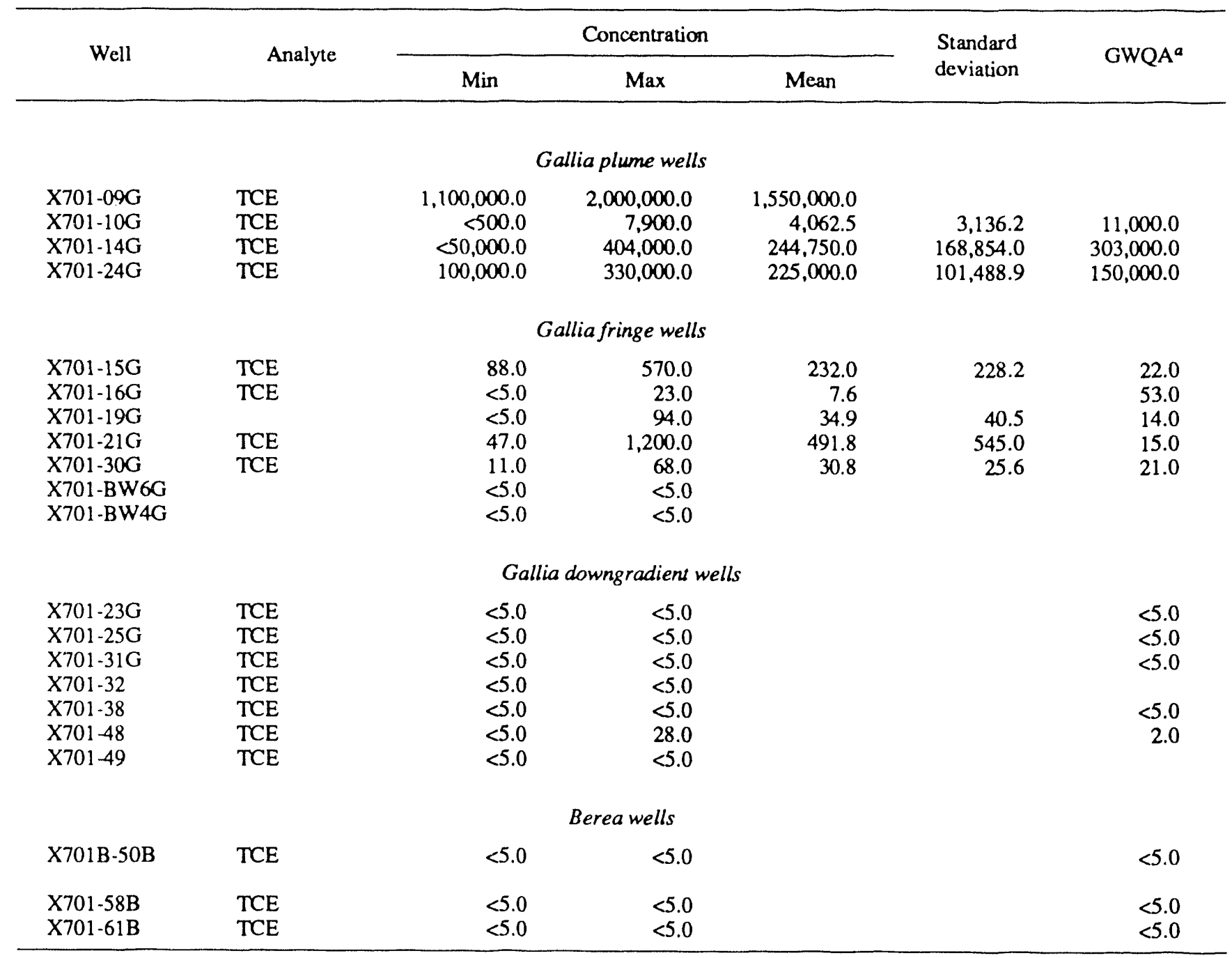


Table 4.3. Monitoring at well field X749 for radionuclide parameters

\begin{tabular}{|c|c|c|c|c|c|c|}
\hline \multirow{2}{*}{ Well } & \multirow{2}{*}{ Parameter } & \multicolumn{3}{|c|}{ Concentration } & \multirow{2}{*}{$\begin{array}{l}\text { Standard } \\
\text { deviation }\end{array}$} & \multirow{2}{*}{ GWQA $^{a}$} \\
\hline & & Min & $\operatorname{Max}$ & Mean & & \\
\hline \multicolumn{7}{|c|}{ Gallia plume wells } \\
\hline$\times 749-07$ & $\begin{array}{l}\text { Technetium }(\mathrm{pCi} / \mathrm{L}) \\
\text { Gross alpha }(\mathrm{pCi} / \mathrm{L}) \\
\text { Gross beta }(\mathrm{pCi} / \mathrm{L}) \\
\text { Uranium }(\mathrm{mg} / \mathrm{L})\end{array}$ & $\begin{array}{c}430.0 \\
62.0 \\
225.0 \\
0.013\end{array}$ & $\begin{array}{l}532.0 \\
163.0 \\
461.0 \\
0.070\end{array}$ & $\begin{array}{l}479.3 \\
117.5 \\
353.5 \\
0.043\end{array}$ & $\begin{array}{l}52.7 \\
97.6 \\
0.025\end{array}$ & $\begin{array}{l}\text { ND } \\
\text { ND } \\
\text { ND } \\
\text { ND }\end{array}$ \\
\hline$X 749-08$ & $\begin{array}{l}\text { Technetium }(\mathrm{pCi} / \mathrm{L}) \\
\text { Gross alpha }(\mathrm{pCi} / \mathrm{L}) \\
\text { Gross beta }(\mathrm{pCi} / \mathrm{L}) \\
\text { Uranium }(\mathrm{mg} / \mathrm{L})\end{array}$ & $\begin{array}{c}294.0 \\
8.0 \\
241.0 \\
0.002\end{array}$ & $\begin{array}{l}359.0 \\
138.0 \\
335.0 \\
0.024\end{array}$ & $\begin{array}{c}320.0 \\
63.8 \\
267.0 \\
0.012\end{array}$ & $\begin{array}{l}59.2 \\
45.4 \\
0.010\end{array}$ & $\begin{array}{l}\text { ND } \\
\text { ND } \\
\text { ND } \\
\text { ND }\end{array}$ \\
\hline$X 749-10$ & $\begin{array}{l}\text { Technetium }(\mathrm{pCi} / \mathrm{L}) \\
\text { Gross alpha }(\mathrm{pCi} / \mathrm{L}) \\
\text { Gross beta }(\mathrm{pCi} / \mathrm{L}) \\
\text { Uranium }(\mathrm{mg} / \mathrm{L})\end{array}$ & $\begin{array}{c}322.0 \\
53.0 \\
365.0 \\
0.018\end{array}$ & $\begin{array}{l}513.0 \\
145.0 \\
513 \\
0.028\end{array}$ & $\begin{array}{c}419.7 \\
93.8 \\
419.0 \\
0.024\end{array}$ & $\begin{array}{l}38.4 \\
70.1 \\
0.005\end{array}$ & $\begin{array}{c}323.0 \\
176.0 \\
319.0 \\
0.054\end{array}$ \\
\hline$X 749-26$ & $\begin{array}{l}\text { Technetium }(\mathrm{pCi} / \mathrm{L}) \\
\text { Gross alpha }(\mathrm{pCi} / \mathrm{L}) \\
\text { Gross beta }(\mathrm{pCi} / \mathrm{L}) \\
\text { Uranium }(\mathrm{mg} / \mathrm{L})\end{array}$ & $\begin{array}{c}236.0 \\
20.0 \\
202.0 \\
0.006\end{array}$ & $\begin{array}{c}510.0 \\
43.0 \\
375.0 \\
0.032\end{array}$ & $\begin{array}{c}377.7 \\
32.2 \\
265.0 \\
0.016\end{array}$ & $\begin{array}{l}9.5 \\
76.0 \\
0.012\end{array}$ & $\begin{array}{c}284.0 \\
51.0 \\
386.0 \\
0.042\end{array}$ \\
\hline \multicolumn{7}{|c|}{ Gallia fringe wells } \\
\hline$\times 749-09$ & $\begin{array}{l}\text { Technetium }(\mathrm{pCi} / \mathrm{L}) \\
\text { Gross alpha }(\mathrm{pCi} / \mathrm{L}) \\
\text { Gross beta }(\mathrm{pCi} / \mathrm{L}) \\
\text { Uranium }(\mathrm{mg} / \mathrm{L})\end{array}$ & $\begin{array}{c}2.0 \\
15.0 \\
20.0 \\
0.008\end{array}$ & $\begin{array}{l}4.0 \\
170.0 \\
267.0 \\
0.046\end{array}$ & $\begin{array}{l}3.7 \\
78.8 \\
90.8 \\
0.028\end{array}$ & $\begin{array}{c}65.4 \\
118.1 \\
0.016\end{array}$ & $\begin{array}{l}\text { ND } \\
\text { ND } \\
\text { ND } \\
\text { ND }\end{array}$ \\
\hline \multicolumn{7}{|c|}{ Gallia downgradient wells } \\
\hline$X 749-23$ & $\begin{array}{l}\text { Technetium }(\mathrm{pCi} / \mathrm{L}) \\
\text { Gross alpha }(\mathrm{pCi} / \mathrm{L}) \\
\text { Gross beta }(\mathrm{pCi} / \mathrm{L}) \\
\text { Uranium }(\mathrm{mg} / \mathrm{L})\end{array}$ & $\begin{array}{c}0.0 \\
1.0 \\
21.0 \\
0.002\end{array}$ & $\begin{array}{l}6.0 \\
28.0 \\
30.0 \\
0.008\end{array}$ & $\begin{array}{l}3.67 \\
16.5 \\
23.8 \\
0.004\end{array}$ & $\begin{array}{r}11.3 \\
4.3\end{array}$ & $\begin{array}{l}25.0 \\
11.0 \\
16.0 \\
0.010\end{array}$ \\
\hline$\times 749-43$ & $\begin{array}{l}\text { Technetium }(\mathrm{pCi} / \mathrm{L}) \\
\text { Gross alpha }(\mathrm{pCi} / \mathrm{L}) \\
\text { Gross beta }(\mathrm{pCi} / \mathrm{L}) \\
\text { Uranium }(\mathrm{mg} / \mathrm{L})\end{array}$ & $\begin{array}{l}-1.0 \\
46.0 \\
31.0 \\
0.037\end{array}$ & $\begin{array}{l}10.0 \\
53.0 \\
64.0 \\
0.062\end{array}$ & $\begin{array}{l}4.7 \\
50.7 \\
46.0 \\
0.048\end{array}$ & & $\begin{array}{l}25.0 \\
13.0 \\
60.0\end{array}$ \\
\hline$\times 749-44$ & $\begin{array}{l}\text { Technetium }(\mathrm{pCi} / \mathrm{L}) \\
\text { Gross alpha }(\mathrm{pCi} / \mathrm{L}) \\
\text { Gross beta }(\mathrm{pCi} / \mathrm{L}) \\
\text { Uranium }(\mathrm{mg} / \mathrm{L})\end{array}$ & $\begin{array}{l}-1.0 \\
2 \mathrm{i} .0 \\
28.0 \\
0.012\end{array}$ & $\begin{array}{c}9.0 \\
123.0 \\
138.0 \\
0.033\end{array}$ & $\begin{array}{c}2.7 \\
47.2 \\
59.0 \\
0.023\end{array}$ & $\begin{array}{l}50.5 \\
53.0 \\
0.009\end{array}$ & $\begin{array}{c}25.0 \\
25.0 \\
15.0 \\
0.026\end{array}$ \\
\hline$\times 749-45$ & $\begin{array}{l}\text { Technetium }(p C i / L) \\
\text { Gross alpha }(p C i / L) \\
\text { Gross beta }(p C i / L) \\
\text { Uranium }(\mathrm{mg} / \mathrm{L})\end{array}$ & $\begin{array}{c}0.0 \\
-1.0 \\
4.0 \\
0.002\end{array}$ & $\begin{array}{l}10.0 \\
24.0 \\
40.0 \\
0.011\end{array}$ & $\begin{array}{l}4.7 \\
10.5 \\
20.0 \\
0.005\end{array}$ & $\begin{array}{c}11.2 \\
-14.9 \\
0.004\end{array}$ & $\begin{array}{c}25.0 \\
6.0 \\
10.0 \\
0.029\end{array}$ \\
\hline
\end{tabular}


Table 4.3 (Continued)

\begin{tabular}{|c|c|c|c|c|c|c|}
\hline \multirow{2}{*}{ Well } & \multirow{2}{*}{ Parameter } & \multicolumn{3}{|c|}{ Concentration } & \multirow{2}{*}{$\begin{array}{l}\text { Standard } \\
\text { deviation }\end{array}$} & \multirow{2}{*}{$\mathrm{GWQA}^{a}$} \\
\hline & & Min & $\operatorname{Max}$ & Mean & & \\
\hline \multicolumn{7}{|c|}{ Berea wells } \\
\hline$X 749-14$ & $\begin{array}{l}\text { Technetium }(\mathrm{pCi} / \mathrm{L}) \\
\text { Gross alpha }(\mathrm{pCi} / \mathrm{L}) \\
\text { Gross beta }(\mathrm{pCi} / \mathrm{L}) \\
\text { Uranium }(\mathrm{mg} / \mathrm{L})\end{array}$ & $\begin{array}{l}-1.0 \\
-1.0 \\
-1 \\
<0.001\end{array}$ & $\begin{array}{l}16.0 \\
5.0 \\
19 \\
<0.002\end{array}$ & $\begin{array}{c}6.3 \\
2.8 \\
9.2 \\
<0.002\end{array}$ & $\begin{array}{l}2.6 \\
8.4\end{array}$ & 0.001 \\
\hline$X 749-25$ & $\begin{array}{l}\text { Technetium }(p C i / L) \\
\text { Gross alpha }(p C i / L) \\
\text { Gross beta }(p C i / L) \\
\text { Uranium }(\mathrm{mg} / \mathrm{L})\end{array}$ & $\begin{array}{l}15.0 \\
1.0 \\
24.0 \\
<0.001\end{array}$ & $\begin{array}{l}50.0 \\
13.0 \\
40.0 \\
0.0050\end{array}$ & $\begin{array}{c}30.0 \\
7.5 \\
32.8 \\
0.002\end{array}$ & $\begin{array}{l}5.9 \\
6.7 \\
0.002\end{array}$ & $\begin{array}{c}20.0 \\
3.0 \\
32.0 \\
0.001\end{array}$ \\
\hline$X 749-36$ & $\begin{array}{l}\text { Technetium }(\mathrm{pCi} / \mathrm{L}) \\
\text { Gross alpha }(\mathrm{pCi} / \mathrm{L}) \\
\text { Gross beta }(\mathrm{pCi} / \mathrm{L}) \\
\text { Uranium }(\mathrm{mg} / \mathrm{L})\end{array}$ & $\begin{array}{c}15.0 \\
9.0 \\
19.0 \\
0.006\end{array}$ & $\begin{array}{l}29.0 \\
24.0 \\
69.0 \\
0.018\end{array}$ & $\begin{array}{l}23.3 \\
17.8 \\
28.0 \\
0.010\end{array}$ & $\begin{array}{c}6.5 \\
18.5 \\
0.006\end{array}$ & $\begin{array}{l}17.0 \\
57.0 \\
62.0 \\
0.047\end{array}$ \\
\hline X749-37 & $\begin{array}{l}\text { Technetium }(\mathrm{pCi} / \mathrm{L}) \\
\text { Gross alpha }(\mathrm{pCi} / \mathrm{L}) \\
\text { Gross beta }(\mathrm{pCi} / \mathrm{L}) \\
\text { Uranium }(\mathrm{mg} / \mathrm{L})\end{array}$ & $\begin{array}{c}7.0 \\
30.0 \\
31.0 \\
0.020\end{array}$ & $\begin{array}{c}27.0 \\
164.0 \\
261.0 \\
0.031\end{array}$ & $\begin{array}{l}17.3 \\
67.5 \\
90.8 \\
0.025\end{array}$ & $\begin{array}{c}64.4 \\
113.6 \\
0.005\end{array}$ & $\begin{array}{l}25.0 \\
88.0 \\
79.0 \\
0.049\end{array}$ \\
\hline \multicolumn{7}{|c|}{ Gallia downgradient wells } \\
\hline$X 749-13$ & $\begin{array}{l}\text { Technetium }(\mathrm{pCi} / \mathrm{L}) \\
\text { Gross alpha }(\mathrm{pCi} / \mathrm{L}) \\
\text { Gross beta }(\mathrm{pCi} / \mathrm{L}) \\
\text { Uranium }(\mathrm{mg} / \mathrm{L})\end{array}$ & $\begin{array}{c}-1.0 \\
46.0 \\
31.0 \\
0.037\end{array}$ & $\begin{array}{l}10.0 \\
53.0 \\
64.0 \\
0.062\end{array}$ & $\begin{array}{c}4.7 \\
50.7 \\
46.0 \\
0.048\end{array}$ & & $\begin{array}{l}10.0 \\
78.0 \\
84.0 \\
0.047\end{array}$ \\
\hline$X 749-21$ & $\begin{array}{l}\text { Technetium }(\mathrm{pCi} / \mathrm{L}) \\
\text { Gross alpha }(\mathrm{pCi} / \mathrm{L}) \\
\text { Gross beta }(\mathrm{pCi} / \mathrm{L}) \\
\text { Uranium }(\mathrm{mg} / \mathrm{L})\end{array}$ & $\begin{array}{c}-3.0 \\
74.0 \\
50.0 \\
0.039\end{array}$ & $\begin{array}{c}7.0 \\
116.0 \\
110.0 \\
0.083\end{array}$ & $\begin{array}{l}3.67 \\
91.8 \\
74.2 \\
0.063\end{array}$ & $\begin{array}{l}20.7 \\
22.8 \\
0.020\end{array}$ & $\begin{array}{c}25.0 \\
117.0 \\
71.0 \\
0.152\end{array}$ \\
\hline \multicolumn{7}{|c|}{ Berea monitoring wells } \\
\hline$X 749-50$ & $\begin{array}{l}\text { Technetium }(p C i / L) \\
\text { Gross alpha }(p C i / L) \\
\text { Gross beta }(p C i / L) \\
\text { Uranium }(m g / L)\end{array}$ & $\begin{array}{c}0.0 \\
24.0 \\
34.0 \\
0.006\end{array}$ & $\begin{array}{c}3.0 \\
51.0 \\
55.0 \\
0.013\end{array}$ & $\begin{array}{c}1.5 \\
40.2 \\
46.2 \\
0.010\end{array}$ & $\begin{array}{l}11.5 \\
8.8 \\
0.003\end{array}$ & $\begin{array}{c}4.0 \\
19.0 \\
26.0 \\
0.003\end{array}$ \\
\hline$X 749-60$ & $\begin{array}{l}\text { Technetium }(p C i / L) \\
\text { Gross alpha }(p C i / L) \\
\text { Gross beta }(p C i / L) \\
\text { Uranium }(m g / L)\end{array}$ & $\begin{array}{c}13.0 \\
34.0 \\
24.0 \\
0.009\end{array}$ & $\begin{array}{c}16.0 \\
111.0 \\
83.0 \\
0.014\end{array}$ & $\begin{array}{l}14.5 \\
58.5 \\
51.8 \\
0.011\end{array}$ & $\begin{array}{l}35.4 \\
29.6 \\
0.002\end{array}$ & $\begin{array}{c}25.0 \\
53.0 \\
55.0 \\
0.023\end{array}$ \\
\hline$\times 749.64$ & $\begin{array}{l}\text { Technetium }(\mathrm{pCi} / \mathrm{L}) \\
\text { Gross alpha }(\mathrm{pCi} / \mathrm{L}) \\
\text { Gross beta }(\mathrm{pCi} / \mathrm{L}) \\
\text { Uranium }(\mathrm{mg} / \mathrm{L})\end{array}$ & $\begin{array}{c}0.0 \\
22.0 \\
54.0 \\
0.002\end{array}$ & $\begin{array}{l}16.0 \\
194.0 \\
375.0 \\
0.063\end{array}$ & $\begin{array}{c}8.0 \\
131.0 \\
147.2 \\
0.030\end{array}$ & $\begin{array}{c}79.5 \\
152.2 \\
0.026\end{array}$ & $\begin{array}{c}25.0 \\
8.0 \\
62.0 \\
0.008\end{array}$ \\
\hline
\end{tabular}

${ }^{a}$ Groundwater quality assessment. 
Table 4.4. Monitoring at well field X231B for volatile organic compounds [ppb $(\mu \mathrm{g} / \mathrm{L})]$

\begin{tabular}{|c|c|c|c|c|c|c|}
\hline \multirow{2}{*}{ Well } & \multirow{2}{*}{ Parameter } & \multicolumn{3}{|c|}{ Concentration } & \multirow{2}{*}{$\begin{array}{l}\text { Standard } \\
\text { deviation }\end{array}$} & \multirow{2}{*}{$\mathrm{GWQA}^{a}$} \\
\hline & & Min & Max & Mean & & \\
\hline \multicolumn{7}{|c|}{ Gallia fringe wells } \\
\hline$\times 749-09$ & $\begin{array}{l}1,1,1-\mathrm{TCA}^{b} \\
1,1-\mathrm{DCA} \\
1,1-\mathrm{DCE} \\
\text { TCE }\end{array}$ & $\begin{array}{l}<5.0 \\
<5.0 \\
<5.0 \\
<5.0\end{array}$ & $\begin{array}{l}<5.0 \\
<5.0 \\
<5.0 \\
<5.0\end{array}$ & & & \\
\hline$X 749-25$ & $\begin{array}{l}1,1,1-T C A \\
1,1-D C A \\
1,1-D C E \\
\text { TCE }\end{array}$ & $\begin{array}{l}<5.0 \\
<5.0 \\
<5.0 \\
<5.0\end{array}$ & $\begin{array}{l}<5.0 \\
<5.0 \\
<5.0 \\
<5.0\end{array}$ & & & $\begin{array}{l}<5.0 \\
<5.0 \\
<5.0 \\
<5.0\end{array}$ \\
\hline$X 749-36$ & $\begin{array}{l}1,1,1-\mathrm{TCA} \\
1,1-\mathrm{DCA} \\
1,1-\mathrm{DCE}\end{array}$ & $\begin{array}{r}580.0 \\
86.0 \\
180.0\end{array}$ & $\begin{array}{l}780.0 \\
180.0 \\
520.0\end{array}$ & $\begin{array}{l}656.7 \\
136.5 \\
407.5\end{array}$ & $\begin{array}{r}107.8 \\
41.9 \\
123.4\end{array}$ & $\begin{array}{l}930.0 \\
150.0 \\
590.0\end{array}$ \\
\hline & $\begin{array}{l}1,2-\mathrm{DCA} \\
\mathrm{TCE}\end{array}$ & $\begin{array}{l}17.8 \\
73.0\end{array}$ & $\begin{array}{l}<50.8 \\
180.8\end{array}$ & 140.8 & 42.3 & $\begin{array}{l}19.0 \\
83.0\end{array}$ \\
\hline$X 749-37$ & $\begin{array}{l}1,1,1-\mathrm{TCA} \\
1,1-\mathrm{DCA} \\
1,1-\mathrm{DCE} \\
\text { TCE }\end{array}$ & $\begin{array}{r}140.0 \\
26.0 \\
87.0 \\
39.0\end{array}$ & $\begin{array}{l}340.0 \\
110.0 \\
230.0 \\
119.0\end{array}$ & $\begin{array}{r}243.3 \\
56.2 \\
141.8 \\
76.4\end{array}$ & $\begin{array}{r}100.2 \\
37.0 \\
64.8 \\
28.8\end{array}$ & $\begin{array}{r}120.0 \\
19.0 \\
75.0 \\
23.0\end{array}$ \\
\hline \multicolumn{7}{|c|}{ Gallia downgradient wells } \\
\hline$\times 749-13$ & $\begin{array}{l}1,1,1-T C A \\
1,1-D C A \\
1,1-D C E \\
\text { TCE }\end{array}$ & $\begin{array}{l}<5.0 \\
<5.0 \\
<5.0 \\
<5.0\end{array}$ & $\begin{array}{l}<5.0 \\
<5.0 \\
<5.0 \\
<5.0\end{array}$ & & & $\begin{array}{l}<5.0 \\
<5.0 \\
<5.0 \\
<5.0\end{array}$ \\
\hline \multicolumn{7}{|c|}{ Gallia plume wells } \\
\hline X749-07 & $\begin{array}{l}\text { 1,1,1-TCA } \\
1,1-\mathrm{DCA} \\
\text { 1,1-DCE } \\
1,2-\mathrm{DCA} \\
\text { TCE } \\
\text { Vinyl chloride }\end{array}$ & $\begin{array}{r}820.0 \\
1,100.0 \\
360.0 \\
<250.0 \\
5,200.0 \\
42.0\end{array}$ & $\begin{array}{r}1,360.0 \\
1,700.0 \\
660.0 \\
370.0 \\
9,700.0 \\
600.0\end{array}$ & $\begin{array}{r}985.8 \\
1,450.0 \\
480.0 \\
281.2 \\
7,750.0 \\
388.5\end{array}$ & $\begin{array}{r}264.5 \\
264.5 \\
158.7 \\
107.4 \\
1,891.2 \\
243.4\end{array}$ & \\
\hline$\times 749-08$ & $\begin{array}{l}1,1,1-\mathrm{TCA} \\
1,1,1-\mathrm{DCE} \\
\text { TCE }\end{array}$ & $\begin{array}{l}430.0 \\
190.0 \\
650.0\end{array}$ & $\begin{array}{l}500.0 \\
260.0 \\
846.0\end{array}$ & $\begin{array}{l}466.7 \\
225.0 \\
730.0\end{array}$ & $\begin{array}{l}35.1 \\
35.1 \\
81.2\end{array}$ & \\
\hline$X 749-10$ & $\begin{array}{l}1,1,1-\mathrm{TCA} \\
1,1-\mathrm{DCA} \\
1,1-\mathrm{DCE} \\
\text { TCE }\end{array}$ & $\begin{array}{r}9,480.0 \\
170.0 \\
4,700.0 \\
7,500.0\end{array}$ & $\begin{array}{r}16,000.0 \\
220.0 \\
5,700.0 \\
8,500.0\end{array}$ & $\begin{array}{r}12,850.0 \\
176.2 \\
5,300.0 \\
8,100.0\end{array}$ & $\begin{array}{r}2,700.0 \\
39.9 \\
454.6 \\
454.6\end{array}$ & $\begin{array}{r}20,000.0 \\
150.0 \\
7,300.0 \\
11,000.0\end{array}$ \\
\hline$X 749-26$ & $\begin{array}{l}1,1,1-\mathrm{TCA} \\
1,1-\mathrm{DCA} \\
1,1-\mathrm{DCE} \\
1,2-\mathrm{DCA} \\
\text { TCE }\end{array}$ & $\begin{array}{r}190.0 \\
330.0 \\
100.0 \\
<100.0 \\
590.0\end{array}$ & $\begin{array}{r}420.0 \\
1,200.0 \\
<500.0 \\
310.0 \\
11,000.0\end{array}$ & $\begin{array}{r}265.0 \\
647.5 \\
147.5 \\
196.8 \\
3,445.0\end{array}$ & $\begin{array}{r}106.6 \\
380.6 \\
70.0 \\
100.1 \\
5,059.1\end{array}$ & $\begin{array}{r}490.0 \\
830.0 \\
170.0 \\
240.0 \\
1,700.0\end{array}$ \\
\hline
\end{tabular}


Table 4.4 (Continued)

\begin{tabular}{|c|c|c|c|c|c|c|}
\hline \multirow{2}{*}{ Well } & \multirow{2}{*}{ Parameter } & \multicolumn{3}{|c|}{ Concentration } & \multirow{2}{*}{$\begin{array}{l}\text { Standard } \\
\text { deviation }\end{array}$} & \multirow{2}{*}{$\mathrm{GWQA}^{a}$} \\
\hline & & Min & $\operatorname{Max}$ & Mean & & \\
\hline \multicolumn{7}{|c|}{ Gallia downgradient wells } \\
\hline$X-749-21$ & $\begin{array}{l}\text { 1,1,1-TCA } \\
1,1-\mathrm{DCA} \\
1,1-\mathrm{DCE} \\
\text { TCE }\end{array}$ & $\begin{array}{l}<5.0 \\
<5.0 \\
<5.0 \\
<5.0\end{array}$ & $\begin{array}{l}<5.0 \\
<5.0 \\
<5.0 \\
<5.0\end{array}$ & & & $\begin{array}{l}<5.0 \\
<5.0 \\
<5.0 \\
<5.0\end{array}$ \\
\hline$\times 749-23$ & $\begin{array}{l}1,1,1-\mathrm{TCA} \\
1,1-\mathrm{DCA} \\
1,1-\mathrm{DCE} \\
\text { TCE }\end{array}$ & $\begin{array}{l}<5.0 \\
<5.0 \\
<5.0 \\
<5.0\end{array}$ & $\begin{array}{l}<5.0 \\
<5.0 \\
<5.0 \\
<5.0\end{array}$ & & & $\begin{array}{l}<5.0 \\
<5.0 \\
<5.0 \\
<5.0\end{array}$ \\
\hline$\times 749-43$ & $\begin{array}{l}1,1,1-\mathrm{TCA} \\
1,1-\mathrm{DCA} \\
1,1-\mathrm{DCE} \\
\text { TCE }\end{array}$ & $\begin{array}{l}<5.0 \\
<5.0 \\
<5.0 \\
<5.0\end{array}$ & $\begin{array}{l}<5.0 \\
<5.0 \\
<5.0 \\
<5.0\end{array}$ & & & $\begin{array}{l}<5.0 \\
<5.0 \\
<5.0 \\
<5.0\end{array}$ \\
\hline$\times 749-44$ & $\begin{array}{l}1,1,1-\mathrm{TCA} \\
1,1-\mathrm{DCA} \\
1,1-\mathrm{DCE} \\
\text { TCE }\end{array}$ & $\begin{array}{l}<5.0 \\
<5.0 \\
<5.0 \\
<5.0\end{array}$ & $\begin{array}{l}<5.0 \\
<5.0 \\
<5.0 \\
260^{c}\end{array}$ & & & $\begin{array}{l}<5.0 \\
<5.0 \\
<5.0 \\
<5.0\end{array}$ \\
\hline$\times 749-45$ & $\begin{array}{l}\text { 1,1,1-TCA } \\
1,1-\mathrm{DCA} \\
1,1-\mathrm{DCE} \\
\text { TCE }\end{array}$ & $\begin{array}{l}<5.0 \\
<5.0 \\
<5.0 \\
<5.0\end{array}$ & $\begin{array}{l}<5.0 \\
<5.0 \\
<5.0 \\
<5.0\end{array}$ & & & $\begin{array}{l}<5.0 \\
<5.0 \\
<5.0 \\
<5.0\end{array}$ \\
\hline \multicolumn{7}{|c|}{ Berea wells } \\
\hline$X 749-14$ & $\begin{array}{l}1,1,1-\mathrm{TCA} \\
1,1-\mathrm{DCA} \\
1,1-\mathrm{DCE} \\
\text { TCE }\end{array}$ & $\begin{array}{l}<5.0 \\
<5.0 \\
<5.0 \\
<5.0\end{array}$ & $\begin{array}{l}<5.0 \\
<5.0 \\
<5.0 \\
<5.0\end{array}$ & & & $\begin{array}{l}<5.0 \\
<5.0 \\
<5.0 \\
<5.0\end{array}$ \\
\hline$\times 749-50$ & $\begin{array}{l}1,1,1-\mathrm{TCA} \\
1,1-\mathrm{DCA} \\
1,1-\mathrm{DCE} \\
\text { TCE }\end{array}$ & $\begin{array}{l}<5.0 \\
<5.0 \\
<5.0 \\
<5.0\end{array}$ & $\begin{array}{r}<5.0 \\
6.8 \\
<5.0 \\
<5.0\end{array}$ & 4.7 & & $\begin{array}{l}<5.0 \\
<5.0 \\
<5.0 \\
<5.0\end{array}$ \\
\hline$X 749 / 60$ & $\begin{array}{l}1,1,1-\mathrm{TCA} \\
1,1-\mathrm{DCA} \\
1,1-\mathrm{DCE} \\
\text { TCE }\end{array}$ & $\begin{array}{l}<5.0 \\
<5.0 \\
<5.0 \\
<5.0\end{array}$ & $\begin{array}{l}<5.0 \\
<5.0 \\
<5.0 \\
<5.0\end{array}$ & & & $\begin{array}{l}<5.0 \\
<5.0 \\
<5.0 \\
<5.0\end{array}$ \\
\hline$\times 749-64$ & $\begin{array}{l}1,1,1-\mathrm{TCA} \\
1,1-\mathrm{DCA} \\
1,1-\mathrm{DCE} \\
\text { TCE }\end{array}$ & $\begin{array}{l}<5.0 \\
<5.0 \\
<5.0 \\
<5.0\end{array}$ & $\begin{array}{l}<5.0 \\
<5.0 \\
<5.0 \\
<5.0\end{array}$ & & & $\begin{array}{l}<5.0 \\
<5.0 \\
<5.0 \\
<5.0\end{array}$ \\
\hline
\end{tabular}

${ }^{a}$ Groundwater quality assessment.

bTrichloroethane.

'VOX sample was collected for the same sampling event and the TCE value was $<5.0 \mathrm{ppb}$, indicating an anomoly in the data. 
Table 4.5. Monitoring at well feld X231B for volatile organic compounds [ppb $(\mu \mathrm{gg} / \mathrm{L})$ ]

\begin{tabular}{|c|c|c|c|c|c|c|}
\hline \multirow{2}{*}{ Well } & \multirow{2}{*}{ Parametcr } & \multicolumn{3}{|c|}{ Concentration } & \multirow{2}{*}{$\begin{array}{l}\text { Standard } \\
\text { dcviation }\end{array}$} & \multirow{2}{*}{ GWQA $^{a}$} \\
\hline & & $\operatorname{Min}$ & Max & Mcan & & \\
\hline \multicolumn{7}{|c|}{ Gallia plume wells } \\
\hline$X 231-04$ & $\begin{array}{l}1,1,1-\mathrm{TCA} \\
1,1-\mathrm{DCE} \\
\text { TCE }\end{array}$ & $\begin{array}{r}<.0 \\
<5.0 \\
370.0\end{array}$ & $\begin{array}{l}<50.0 \\
<50.0 \\
730.0\end{array}$ & 512.5 & 158.8 & $\begin{array}{l}<25.0 \\
<25.0 \\
490.0\end{array}$ \\
\hline$X 231-15$ & $\begin{array}{l}1,1,1-T C A \\
1,1-D C E \\
\text { TCE }\end{array}$ & $\begin{array}{r}92.0 \\
<50.0 \\
<5.0\end{array}$ & $\begin{array}{r}120.0 \\
89.0 \\
210.0\end{array}$ & $\begin{array}{r}110.5 \\
62.2 \\
148.1\end{array}$ & $\begin{array}{l}13.2 \\
27.5 \\
97.9\end{array}$ & $\begin{array}{r}\left.66^{\prime}\right) .0 \\
23.0 \\
240.0\end{array}$ \\
\hline \multicolumn{7}{|c|}{ Gallia fringe wells } \\
\hline$X 231-14$ & $\begin{array}{l}1,1,1-T C A \\
1,1-D C E \\
\text { TCE }\end{array}$ & $\begin{array}{r}<5.0 \\
<5.0 \\
9.3\end{array}$ & $\begin{array}{l}<5.0 \\
<5.0 \\
23.0\end{array}$ & 18.6 & 6.2 & $\begin{array}{l}<5.0 \\
18\end{array}$ \\
\hline$X 231-23$ & $\begin{array}{l}1,1,1-\text { TCA } \\
1,1-D C E \\
\text { TCE }\end{array}$ & $\begin{array}{l}36.0 \\
18.0 \\
<5.0\end{array}$ & $\begin{array}{l}790.0 \\
380.0 \\
890.0\end{array}$ & $\begin{array}{l}224.8 \\
112.2 \\
242.4\end{array}$ & $\begin{array}{l}376.9 \\
178.5 \\
432.2\end{array}$ & $\begin{array}{r}6.0 \\
<5.0 \\
16.0\end{array}$ \\
\hline \multicolumn{7}{|c|}{ Gallia downgradient wells } \\
\hline$X 231-16$ & $\begin{array}{l}1,1,1-\mathrm{TCA} \\
1,1-\mathrm{DCE} \\
\text { TCE }\end{array}$ & $\begin{array}{l}<5.0 \\
<5.0 \\
<5.0\end{array}$ & $\begin{array}{l}<50.0 \\
<50.0 \\
570.0^{b}\end{array}$ & & & $\begin{array}{l}<5.0 \\
<5.0 \\
18.0\end{array}$ \\
\hline$\times 231-27$ & $\begin{array}{l}1,1,1-T C A \\
1,1-D C E \\
\text { TCE }\end{array}$ & $\begin{array}{l}<5.0 \\
<5.0 \\
<5.0\end{array}$ & $\begin{array}{l}<5.0 \\
<5.0 \\
<5.0\end{array}$ & & & $\begin{array}{l}<5.0 \\
<5.0 \\
<5.0\end{array}$ \\
\hline$X 231-28$ & $\begin{array}{l}1,1,1-\mathrm{TCA} \\
1,1-\mathrm{DCE} \\
\text { TCE }\end{array}$ & $\begin{array}{l}<5.0 \\
<5.0 \\
<5.0\end{array}$ & $\begin{array}{l}<5.0 \\
<5.0 \\
5.0\end{array}$ & & & $\begin{array}{l}<5.0 \\
<5.0 \\
<5.0\end{array}$ \\
\hline \multicolumn{7}{|c|}{ Berea wells } \\
\hline$X 231-24$ & $\begin{array}{l}1,1,1-\mathrm{TCA} \\
1,1-\mathrm{DCE} \\
\text { TCE }\end{array}$ & $\begin{array}{l}<5.0 \\
<5.0 \\
<5.0\end{array}$ & $\begin{array}{l}<5.0 \\
<5.0 \\
<5.0\end{array}$ & & & $\begin{array}{l}<5.0 \\
<5.0 \\
12.0\end{array}$ \\
\hline$X-231-32$ & $\begin{array}{l}1,1,1-\mathrm{TCA} \\
1,1-\mathrm{DCE} \\
\text { TCE }\end{array}$ & $\begin{array}{l}<5.0 \\
<5.0 \\
<5.0\end{array}$ & $\begin{array}{l}<5.0 \\
<5.0 \\
<5.0\end{array}$ & & & $\begin{array}{l}<5.0 \\
<5.0 \\
<5.0\end{array}$ \\
\hline$X 231-33$ & $\begin{array}{l}1,1,1-\text { TCA } \\
1,1-D C E \\
\text { TCE }\end{array}$ & $\begin{array}{l}<5.0 \\
<5.0 \\
<5.0\end{array}$ & $\begin{array}{l}<5.0 \\
<5.0 \\
<5.0\end{array}$ & & & $\begin{array}{l}<5.0 \\
<5.0 \\
<5.0\end{array}$ \\
\hline$X 231-34$ & $\begin{array}{l}1,1,1-\mathrm{TCA} \\
1,1-\mathrm{DCE} \\
\text { TCE }\end{array}$ & $\begin{array}{l}<5.0 \\
<5.0 \\
<5.0\end{array}$ & $\begin{array}{l}<5.0 \\
<5.0 \\
<5.0\end{array}$ & & & $\begin{array}{l}<5.0 \\
<5.0 \\
<5.0\end{array}$ \\
\hline \multicolumn{7}{|c|}{ Gallia downgradient wells } \\
\hline$X 231-37$ & $\begin{array}{l}1,1,1-\text { TCA } \\
1,1-D C E \\
\text { TCE }\end{array}$ & $\begin{array}{l}<5.0 \\
<5.0 \\
<5.0\end{array}$ & $\begin{array}{l}<5.0 \\
<5.0 \\
>0.0\end{array}$ & 33.8 & 36.3 & \\
\hline
\end{tabular}

${ }^{a} \mathrm{G}$ roundwatcr quality asscssment.

${ }^{b}$ VOX sample was collected for the same sampling event and the TCE value was $<5.0$ ppl), indicating an anomoly in the data. 
Table 4.6. Monitoring at well field X231B for radionuclide parameters

\begin{tabular}{|c|c|c|c|c|c|c|}
\hline \multirow{2}{*}{ Wel! } & \multirow{2}{*}{ Parameter } & \multicolumn{3}{|c|}{ Concentration } & \multirow{2}{*}{$\begin{array}{l}\text { Standard } \\
\text { deviation }\end{array}$} & \multirow{2}{*}{ GWQA $^{a}$} \\
\hline & & Min & $\operatorname{Max}$ & Mean & & \\
\hline \multicolumn{7}{|c|}{ Gallia plume wells } \\
\hline$X 231-4$ & $\begin{array}{l}\text { Technetium }(\mathrm{pCi} / \mathrm{L}) \\
\text { Gross alpha }(\mathrm{pCi} / \mathrm{L}) \\
\text { Gross beta }(\mathrm{pCi} / \mathrm{L}) \\
\text { Uranium }(\mathrm{mg} / \mathrm{L})\end{array}$ & $\begin{array}{l}46.0 \\
78.0 \\
54.0 \\
0.016\end{array}$ & $\begin{array}{c}74.0 \\
145.0 \\
85.0 \\
0.040\end{array}$ & $\begin{array}{l}60.0 \\
99.8 \\
68.8 \\
0.023\end{array}$ & $\begin{array}{l}30.8 \\
12.7 \\
0.011\end{array}$ & $\begin{array}{l}88.0 \\
76.0 \\
83.0 \\
0.017\end{array}$ \\
\hline$\times 231-15$ & $\begin{array}{l}\text { Technetium }(\mathrm{pCi} / \mathrm{L}) \\
\text { Gross alpha }(\mathrm{pCi} / \mathrm{L}) \\
\text { Gross beta }(\mathrm{pCi} / \mathrm{L}) \\
\text { Uranium }(\mathrm{mg} / \mathrm{L})\end{array}$ & $\begin{array}{l}3.0 \\
-3.0 \\
-2.0 \\
0.001\end{array}$ & $\begin{array}{c}12.0 \\
23.0 \\
24.0 \\
0.008\end{array}$ & $\begin{array}{c}7.5 \\
9.8 \\
14.2 \\
0.004\end{array}$ & $\begin{array}{l}10.6 \\
11.3 \\
0.004\end{array}$ & $\begin{array}{c}5.0 \\
8.0 \\
60.0 \\
0.015\end{array}$ \\
\hline \multicolumn{7}{|c|}{ Gallia fringe wells } \\
\hline$X 231-14$ & $\begin{array}{l}\text { Technetium }(\mathrm{pCi} / \mathrm{L}) \\
\text { Gross alpha }(\mathrm{pCi} / \mathrm{L}) \\
\text { Gross beta }(\mathrm{pCi} / \mathrm{L}) \\
\text { Uranium }(\mathrm{mg} / \mathrm{L})\end{array}$ & $\begin{array}{r}0.0 \\
4.0 \\
-13.0 \\
0.0010\end{array}$ & $\begin{array}{l}-2.0 \\
13.0 \\
12.0 \\
0.0020\end{array}$ & $\begin{array}{l}7.3 \\
3.8 \\
0.0012\end{array}$ & $\begin{array}{l}4.3 \\
11.8 \\
0.0005\end{array}$ & $\begin{array}{l}0.00 \\
13.0 \\
29.0 \\
0.004\end{array}$ \\
\hline$X 231-23$ & $\begin{array}{l}\text { Technetium }(\mathrm{pCi} / \mathrm{L}) \\
\text { Gross alpha }(\mathrm{pCi} / \mathrm{L}) \\
\text { Gross beta }(\mathrm{pCi} / \mathrm{L}) \\
\text { Uranium }(\mathrm{mg} / \mathrm{L})\end{array}$ & $\begin{array}{l}2.0 \\
4.0 \\
-1.0 \\
<0.001\end{array}$ & $\begin{array}{c}19.0 \\
31.0 \\
114.0 \\
0.016\end{array}$ & $\begin{array}{l}10.5 \\
11.5 \\
32.0 \\
0.005\end{array}$ & $\begin{array}{l}13.0 \\
54.9 \\
0.007\end{array}$ & $\begin{array}{l}4.0 \\
10.0 \\
12.0 \\
0.003\end{array}$ \\
\hline \multicolumn{7}{|c|}{ Gallia downgradient wells } \\
\hline$X 231-16$ & $\begin{array}{l}\text { Technetium }(\mathrm{pCi} / \mathrm{L}) \\
\text { Gross alpha }(\mathrm{pCi} / \mathrm{L}) \\
\text { Gross beta }(\mathrm{pCi} / \mathrm{L}) \\
\text { Uranium (mg/L) }\end{array}$ & $\begin{array}{c}-1.0 \\
-15.0 \\
4.0 \\
<0.002\end{array}$ & $\begin{array}{c}15.0 \\
9.0 \\
12.0 \\
0.008\end{array}$ & $\begin{array}{c}7.0 \\
-5.8 \\
7.2 \\
0.004\end{array}$ & $\begin{array}{l}11.2 \\
3.6 \\
0.002\end{array}$ & $\begin{array}{l}25.0 \\
64.0 \\
22.0 \\
0.019\end{array}$ \\
\hline$X 231-27$ & $\begin{array}{l}\text { Technetium }(\mathrm{pCi} / \mathrm{L}) \\
\text { Gross alpha }(\mathrm{pC} \mathrm{i} / \mathrm{L}) \\
\text { Gross beta }(\mathrm{pCi} / \mathrm{L}) \\
\text { Uranium }(\mathrm{mg} / \mathrm{L})\end{array}$ & $\begin{array}{l}6.0 \\
11.0 \\
16.0 \\
0.003\end{array}$ & $\begin{array}{l}7.0 \\
44.0 \\
60.0 \\
0.006\end{array}$ & $\begin{array}{l}6.5 \\
24.8 \\
38.8 \\
0.005\end{array}$ & $\begin{array}{l}16.5 \\
18.2 \\
0.001\end{array}$ & $\begin{array}{l}25.00 \\
26.0 \\
32.0 \\
0.004\end{array}$ \\
\hline$X 231-28$ & $\begin{array}{l}\text { Technetium (pCi/L) } \\
\text { Gross alpha }(\mathrm{pCi} / \mathrm{L}) \\
\text { Gross beta }(\mathrm{pCi} / \mathrm{L}) \\
\text { Uranium (mg/L) }\end{array}$ & $\begin{array}{l}2.0 \\
3.0 \\
3.0 \\
<0.001\end{array}$ & $\begin{array}{c}10.0 \\
23.0 \\
21.0 \\
0.011\end{array}$ & $\begin{array}{l}6.0 \\
12.8 \\
11.2 \\
0.005\end{array}$ & $\begin{array}{l}10.2 \\
7.7 \\
0.004\end{array}$ & $\begin{array}{l}25.0 \\
38.0 \\
12.0 \\
0.021\end{array}$ \\
\hline$X 231-37$ & $\begin{array}{l}\text { Technetium (pCi/L) } \\
\text { Gross alpha }(p C i / L) \\
\text { Gross beta }(p C i / L) \\
\text { Uranium (mg/L) }\end{array}$ & $\begin{array}{c}3.0 \\
13.0 \\
21.0 \\
0.004\end{array}$ & $\begin{array}{l}3.0 \\
75.0 \\
63.0 \\
0.047\end{array}$ & $\begin{array}{l}40.8 \\
34.8 \\
0.026\end{array}$ & $\begin{array}{l}25.6 \\
19.2 \\
0.018\end{array}$ & \\
\hline
\end{tabular}


Table 4.6 (Continued)

\begin{tabular}{|c|c|c|c|c|c|c|}
\hline \multirow{2}{*}{ Well } & \multirow{2}{*}{ Parameter } & \multicolumn{3}{|c|}{ Concentration } & \multirow{2}{*}{$\begin{array}{l}\text { Standard } \\
\text { deviation }\end{array}$} & \multirow{2}{*}{ GWQA $^{c}$} \\
\hline & & Min & Max & Mean & & \\
\hline \multicolumn{7}{|c|}{ Berea wells } \\
\hline $\mathrm{X} 231.24$ & $\begin{array}{l}\text { Technetium }(\mathrm{pCi} / \mathrm{L}) \\
\text { Gross alpha }(\mathrm{pCi} / \mathrm{L}) \\
\text { Gross beta }(\mathrm{pCi} / \mathrm{L}) \\
\text { Uranium }(\mathrm{mg} / \mathrm{L})\end{array}$ & $\begin{array}{c}0.0 \\
13.0 \\
16.0 \\
0.003\end{array}$ & $\begin{array}{l}20.0 \\
39.0 \\
60.0 \\
0.006\end{array}$ & $\begin{array}{c}1.0 \\
22.8 \\
38.8 \\
0.005\end{array}$ & $\begin{array}{l}11.6 \\
18.2 \\
0.001\end{array}$ & $\begin{array}{l}5.0 \\
38.0 \\
25.0 \\
0.014\end{array}$ \\
\hline$X 231-32$ & $\begin{array}{l}\text { Technetium }(\mathrm{pCi} / \mathrm{L}) \\
\text { Gross alpha }(\mathrm{pCi} / \mathrm{L}) \\
\text { Gross beta }(\mathrm{pCi} / \mathrm{L}) \\
\text { Uranium }(\mathrm{mg} / \mathrm{L})\end{array}$ & $\begin{array}{c}0.0 \\
-14.0 \\
26.0 \\
0.009\end{array}$ & $\begin{array}{c}7.0 \\
383.0 \\
441.0 \\
0.036\end{array}$ & $\begin{array}{c}3.5 \\
105.5 \\
160.8 \\
0.024\end{array}$ & $\begin{array}{c}188.0 \\
190.9 \\
0.012\end{array}$ & $\begin{array}{c}9.0 \\
2.0 \\
37.0 \\
0.001\end{array}$ \\
\hline X231-33 & $\begin{array}{l}\text { Technetium }(\mathrm{pCi} / \mathrm{L}) \\
\text { Gross alpha }(\mathrm{pCi} / \mathrm{L}) \\
\text { Gross beta }(\mathrm{pCi} / \mathrm{L}) \\
\text { Uranium }(\mathrm{mg} / \mathrm{L})\end{array}$ & $\begin{array}{c}6.0 \\
63.0 \\
47.0 \\
0.012\end{array}$ & $\begin{array}{c}18.0 \\
293.0 \\
119.0 \\
0.024\end{array}$ & $\begin{array}{c}12.0 \\
136.8 \\
81.8 \\
0.015\end{array}$ & $\begin{array}{c}105.5 \\
38.0 \\
0.006\end{array}$ & $\begin{array}{c}5.0 \\
51.0 \\
81.0 \\
0.001\end{array}$ \\
\hline X231-34 & $\begin{array}{l}\text { Technetium }(\mathrm{pCi} / \mathrm{L}) \\
\text { Gross alpha (pCi/L) } \\
\text { Gross beta }(\mathrm{pCi} / \mathrm{L}) \\
\text { Uranium }(\mathrm{mg} / \mathrm{L})\end{array}$ & $\begin{array}{l}3.0 \\
14.0 \\
18.0 \\
0.002\end{array}$ & $\begin{array}{l}11.0 \\
25.0 \\
32.0 \\
0.006\end{array}$ & $\begin{array}{c}7.0 \\
18.8 \\
23.0 \\
0.004\end{array}$ & $\begin{array}{l}5.2 \\
6.2 \\
0.002\end{array}$ & $\begin{array}{l}17.0 \\
76.0 \\
50.0 \\
0.011\end{array}$ \\
\hline
\end{tabular}

${ }^{a}$ Groundwater quality assessment. 
Table 4.7. Surface water assessment monitoring at Little Beaver Creek (LBC) for volatile organic compounds [ppb $(\mu \mathrm{g} / \mathrm{L})$ ]

\begin{tabular}{clcccc}
\hline \multirow{2}{*}{ Site } & Parameter & \multicolumn{3}{c}{ Concentration } & Standard \\
\cline { 3 - 6 } & & Min & Max & Mean & deviation \\
\hline \multirow{2}{*}{ LBC-SW01 } & 1,1,1-TCA & $<5.0$ & $<50.0$ & \\
& TCE & 80.0 & 220.0 & 94.4 & 83.0 \\
IBC-SW02 & 1,1,1-TCA & $<5.0$ & $<5.0$ & & \\
& TCE & 32.0 & 71.0 & 49.5 & 19.5 \\
LBC-SW03 & 1,1,1-TCA & $<5.0$ & $<5.0$ & $<.0$ & \\
& TCE & $<.0$ & 17.0 & 7.5 & 6.8 \\
\hline
\end{tabular}

Table 4.8. Surface water assessment monitoring at unnamed drainage (UND) at southwest corner of plant for volatile organic compounds [ppb $(\mu \mathrm{g} / \mathrm{L})]$

\begin{tabular}{clcc}
\hline \multirow{2}{*}{ Site } & Parameter & \multicolumn{2}{c}{ Concentration } \\
\cline { 3 - 4 } & & Min & Max \\
\hline \multirow{2}{*}{ UND-SW01 } & $1,1,1-$ TCA & $<5.0$ & $<5.0$ \\
& TCE & $<5.0$ & $<5.0$ \\
UND-SW02 & $1,1,1-$ TCA & $<5.0$ & $<5.0$ \\
& TCE & 3.0 & $<5.0$ \\
\hline
\end{tabular}

Table 4.9. Suriace water assessment monitoring at Big Run Cre $-k(B R C)$ for volatile organic compounds [ppb $(\mu \mathrm{g} / \mathrm{L})]$

\begin{tabular}{clll}
\hline \multirow{2}{*}{ Site } & Parameter & \multicolumn{2}{c}{ Concentration } \\
\cline { 3 - 4 } & & Min & Max \\
\hline \multirow{2}{*}{ BRC-SW01 } & $1,1,1$-TCA & $<5.0$ & $<5.0$ \\
& TCE & $<5.0$ & $<5.0$ \\
BRC-SW02 & $1,1,1$-TCA & $<5.0$ & $<5.0$ \\
& TCE & $<5.0$ & $<5.0$ \\
\hline
\end{tabular}


Table 4.10. Surface water assessment monitoring at Little Beaver Creek (LBC) for radionuclide parameters

\begin{tabular}{|c|c|c|c|c|c|}
\hline \multirow{2}{*}{ Site } & \multirow{2}{*}{ Parameter } & \multicolumn{3}{|c|}{ Concentration } & \multirow{2}{*}{$\begin{array}{l}\text { Standard } \\
\text { deviation }\end{array}$} \\
\hline & & $\operatorname{Min}$ & $\operatorname{Max}$ & Mean & \\
\hline \multirow[t]{4}{*}{ LBC-SW01 } & Technetium (pCi/L) & 3.0 & 8.0 & 6.3 & \\
\hline & Gross alpha $(\mathrm{pCi} / \mathrm{L})$ & -4.0 & 5.0 & 0.5 & 3.9 \\
\hline & Gross beta $(p \mathrm{C} / \mathrm{L})$ & -3.0 & 9.0 & 4.0 & 5.1 \\
\hline & Uranium $(\mathrm{mg} / \mathrm{L})$ & $<0.001$ & $<0.002$ & $<0.002$ & \\
\hline \multirow[t]{4}{*}{ LBC-SW02 } & Technetium (pCi/L) & 29.0 & 40.0 & 33.3 & \\
\hline & Gross alpha $(\mathrm{pCi} / \mathrm{L})$ & 6.0 & 48.0 & 34.0 & 19.6 \\
\hline & Gross beta $(p C i / L)$ & 23.0 & 45.0 & 35.2 & 10.5 \\
\hline & Uranium (mg/L) & 0.002 & 0.005 & 0.004 & 0.002 \\
\hline \multirow[t]{4}{*}{ LBC-SW03 } & Technetium (pCi/L) & 33.0 & 39.0 & 35.3 & \\
\hline & Gross alpha (pCi/L) & 15.0 & 50.0 & 38.0 & 15.7 \\
\hline & Gross beta $(p C i / L)$ & 23.0 & 42.0 & 33.2 & 8.8 \\
\hline & Uranium (mg/L) & 0.002 & 0.006 & 0.004 & 0.002 \\
\hline
\end{tabular}

Table 4.11. Surface vater assessment monitoring at unnamed drainage (UND) southwest of plant site for radionuclide parameters

\begin{tabular}{|c|c|c|c|c|c|}
\hline \multirow{2}{*}{ Site } & \multirow{2}{*}{ Parameter } & \multicolumn{3}{|c|}{ Concentration } & \multirow{2}{*}{$\begin{array}{l}\text { Standard } \\
\text { deviation }\end{array}$} \\
\hline & & $\operatorname{Min}$ & $\operatorname{Max}$ & Mean & \\
\hline \multirow[t]{4}{*}{ UND-SW01 } & Technetium $(\mathrm{pC} / \mathrm{L})$ & 1.0 & 7.0 & 4.2 & 2.1 \\
\hline & Gross alpha (pCi/L) & 1.0 & 14.0 & 6.0 & 5.6 \\
\hline & Gross beta (pCi/L) & 0.0 & 13.0 & 5.8 & 5.6 \\
\hline & Uranium $(\mathrm{mg} / \mathrm{L})$ & $<0.002$ & 0.002 & & \\
\hline \multirow[t]{4}{*}{ UND-SW02 } & Tect zetium (pCi/L) & 1.0 & 8.0 & 4.7 & \\
\hline & Gross alpha (pCi/L) & -2.0 & 3.0 & 0.8 & 2.2 \\
\hline & Gross beta $(\mathrm{pC} / \mathrm{L})$ & -1.0 & 7.0 & 2.8 & 3.5 \\
\hline & Uranium (mg/L) & $<0.001$ & $<0.002$ & & \\
\hline
\end{tabular}


Table 4.12. Surface water assessment monitoring at Big Run Creek (BRC) for radionuclide parameters

\begin{tabular}{|c|c|c|c|c|c|}
\hline \multirow{2}{*}{ Well } & \multirow{2}{*}{ Parameter } & \multicolumn{3}{|c|}{ Concentration } & \multirow{2}{*}{$\begin{array}{l}\text { Standard } \\
\text { deviation }\end{array}$} \\
\hline & & Min & $\operatorname{Max}$ & Mean & \\
\hline \multirow[t]{4}{*}{ BRC-SW01 } & Technetium (pCi/L) & 1.0 & 7.0 & 3.7 & \\
\hline & Gross alpha (pCi/L) & 1.0 & 4.0 & 3.0 & 1.4 \\
\hline & Gross beta $(\mathrm{pCi} / \mathrm{L})$ & 0.0 & 11.0 & 6.0 & 5.0 \\
\hline & Uranium $(\mathrm{mg} / \mathrm{L})$ & 0.001 & 0.017 & 0.005 & 0.008 \\
\hline \multirow[t]{4}{*}{ BRC-SW02 } & Technetium (pCi/L) & 7.0 & 11.0 & 8.7 & \\
\hline & Gross alpha $(\mathrm{pCi} / \mathrm{L})$ & -3.0 & 10.0 & 2.8 & 5.4 \\
\hline & Gross beta (pCi/L) & 1.0 & 6.0 & 4.2 & 2.2 \\
\hline & Uranium (mg/L) & 0.001 & 0.002 & & \\
\hline
\end{tabular}

Table 4.13 . Surface water assessment monitoring at well field at X616 sludge impoundments for total chromium (mg/L)

\begin{tabular}{|c|c|c|c|c|c|}
\hline \multirow{2}{*}{ Well } & \multirow{2}{*}{ Parameter } & \multicolumn{3}{|c|}{ Concentration } & \multirow{2}{*}{$\begin{array}{l}\text { Standard } \\
\text { deviation }\end{array}$} \\
\hline & & Min & $\operatorname{Max}$ & Mean & \\
\hline \multicolumn{6}{|c|}{ Gallia wells } \\
\hline X616-05 & $\begin{array}{l}\mathrm{Cr} \\
\mathrm{Cr}^{6+}\end{array}$ & 0.50 & $\begin{array}{c}2.30 \\
<0.010\end{array}$ & 1.00 & 0.87 \\
\hline X616-10 & $\begin{array}{l}\mathrm{Cr}_{\mathrm{r}} \\
\mathrm{Cr}^{6+}\end{array}$ & $<0.010$ & $\begin{array}{r}0.076 \\
<0.010\end{array}$ & 0.032 & 0.032 \\
\hline X616-14 & $\begin{array}{l}\mathrm{Cr}_{\mathrm{r}} \\
\mathrm{Cr}^{6+}\end{array}$ & 0.011 & $\begin{array}{r}0.165 \\
<0.010\end{array}$ & 0.068 & 0.067 \\
\hline$X 616-16$ & $\begin{array}{l}\mathrm{Cr} \\
\mathrm{Cr}^{6+}\end{array}$ & $<0.010$ & $\begin{array}{r}0.061 \\
<0.010\end{array}$ & 0.019 & 0.028 \\
\hline$X 616-17$ & $\begin{array}{l}\mathrm{Cr} \\
\mathrm{Cr}^{6+}\end{array}$ & 0.130 & $\begin{array}{r}0.450 \\
<0.010\end{array}$ & 0.223 & 0.150 \\
\hline X616-21 & $\begin{array}{l}\mathrm{Cr} \\
\mathrm{Cr}^{6+}\end{array}$ & 0.012 & $\begin{array}{r}0.320 \\
<0.010\end{array}$ & 0.139 & 0.130 \\
\hline$X 616-22$ & $\begin{array}{l}\mathrm{Cr} \\
\mathrm{Cr}^{6+}\end{array}$ & 0.015 & $\begin{array}{r}0.140 \\
<0.010\end{array}$ & 0.055 & 0.058 \\
\hline$X 616-25$ & $\begin{array}{l}\mathrm{Cr} \\
\mathrm{Cr}^{6+}\end{array}$ & $<0.010$ & $\begin{array}{r}0.228 \\
<0.010\end{array}$ & 0.082 & 0.101 \\
\hline$X 616-26$ & $\begin{array}{l}\mathrm{Cr} \\
\mathrm{Cr}^{6+}\end{array}$ & $<0.010$ & $\begin{array}{r}0.052 \\
<0.010\end{array}$ & 0.054 & 0.074 \\
\hline \multicolumn{6}{|c|}{ Berea wells } \\
\hline X616-19 & $\begin{array}{l}\mathrm{Cr} \\
\mathrm{Cr}^{6+}\end{array}$ & 0.018 & $\begin{array}{r}0.360 \\
<0.010\end{array}$ & 0.193 & 0.179 \\
\hline$X 616-24$ & $\begin{array}{l}\mathrm{Cr} \\
\mathrm{C} r^{6+}\end{array}$ & 0.041 & $\begin{array}{r}0.075 \\
-0.010\end{array}$ & 0.058 & \\
\hline X616-28 & $\begin{array}{l}\mathrm{Cr} \\
\mathrm{Cr}^{6+}\end{array}$ & 0.026 & $\begin{array}{r}0.042 \\
<0.010\end{array}$ & 0.034 & \\
\hline
\end{tabular}


Table 4.14. Monitoring of background wells at X616 sludge impoundments for total chromium (mg/L)

\begin{tabular}{|c|c|c|c|c|}
\hline \multirow{2}{*}{ Well } & \multirow{2}{*}{ Parameter } & \multicolumn{3}{|c|}{ Concentration } \\
\hline & & Min & $\operatorname{Max}$ & Mean \\
\hline \multicolumn{5}{|c|}{ Gallia wells } \\
\hline F-01 & $\begin{array}{l}\mathrm{Cr} \\
\mathrm{Cr}^{6+}\end{array}$ & 0.011 & $\begin{array}{r}0.045 \\
<0.010\end{array}$ & 0.027 \\
\hline F-11 & $\begin{array}{l}\mathrm{Cr} \\
\mathrm{Cr}^{6+}\end{array}$ & 0.530 & $\begin{array}{r}3.200 \\
<0.010\end{array}$ & 2.110 \\
\hline F-13 & $\begin{array}{l}\mathrm{Cr} \\
\mathrm{Cr}^{6+}\end{array}$ & 0.015 & $\begin{array}{r}0.150 \\
<0.010\end{array}$ & 0.071 \\
\hline F-17 & $\begin{array}{l}\mathrm{Cr} \\
\mathrm{Cr}^{6+}\end{array}$ & 0.028 & $\begin{array}{r}0.087 \\
<0.010\end{array}$ & 0.060 \\
\hline F-23 & $\begin{array}{l}\mathrm{Cr} \\
\mathrm{Cr}^{6+}\end{array}$ & 0.230 & $\begin{array}{r}2.200 \\
<0.010\end{array}$ & 0.933 \\
\hline F-25 & $\begin{array}{l}\mathrm{Cr}_{\mathrm{r}} \\
\mathrm{Cr}^{6+}\end{array}$ & 0 & $\begin{array}{r}0.038 \\
<0.010\end{array}$ & \\
\hline F-27 & $\begin{array}{l}\mathrm{Cr} \\
\mathrm{Cr}^{6+}\end{array}$ & 0.015 & $\begin{array}{r}0.220 \\
<0.010\end{array}$ & 0.148 \\
\hline$\times 701-47$ & $\begin{array}{l}\mathrm{Cr} \\
\mathrm{Cr}^{6+}\end{array}$ & 0.150 & $\begin{array}{r}0.520 \\
<0.010\end{array}$ & 0.293 \\
\hline$\times 749-45$ & $\begin{array}{l}\mathrm{Cr} \\
\mathrm{Cr}^{6+}\end{array}$ & 0.013 & $\begin{array}{r}0.180 \\
<0.010\end{array}$ & 0.043 \\
\hline \multicolumn{5}{|c|}{ Berea wells } \\
\hline F-02 & $\begin{array}{l}\mathrm{Cr} \\
\mathrm{Cr}^{6+}\end{array}$ & & $\begin{array}{r}0.010 \\
<0.010\end{array}$ & \\
\hline$\times 701-60$ & $\begin{array}{l}\mathrm{Cr} \\
\mathrm{Cr}^{6+}\end{array}$ & & $\begin{array}{c}0.64 \\
<0.010\end{array}$ & \\
\hline$X 749-60$ & $\begin{array}{l}\mathrm{Cr} \\
\mathrm{Cr}^{6+}\end{array}$ & & $\begin{array}{r}0.130 \\
<0.010\end{array}$ & \\
\hline$X 749-61$ & $\begin{array}{l}\mathrm{Cr} \\
\mathrm{Cr}^{6+}\end{array}$ & & $\begin{array}{r}0.039 \\
<0.010\end{array}$ & \\
\hline$X 749-63$ & $\begin{array}{l}\mathrm{Cr} \\
\mathrm{Cr}^{6+}\end{array}$ & & $\begin{array}{r}0.070 \\
<0.010\end{array}$ & \\
\hline
\end{tabular}




\section{BIOLOGICAL SAMPLING}


Table 5.1. 19:40 vegetables and fruit

\begin{tabular}{llccc}
\hline \multicolumn{1}{c}{ Sample } & $\begin{array}{c}\text { Date } \\
\text { sampled }\end{array}$ & $\begin{array}{c}\text { Uranium } \\
(\mu \mathrm{g} / \mathrm{g})\end{array}$ & $\begin{array}{c}\text { Uranium } \\
\text { alpha } \\
(\mathrm{pCi} / \mathrm{g})\end{array}$ & $\begin{array}{c}\text { Technetium } \\
\text { beta } \\
(\mathrm{pCi} / \mathrm{g})\end{array}$ \\
\hline Corn & 28 -Sep-90 & $<0.05$ & 0.0 & 0.4 \\
Corn & 28 -Sep-90 & $<0.05$ & 0.1 & 0.6 \\
Com & 28 -Sep-90 & $<0.05$ & -0.1 & 0.9 \\
Tomatoes & $28-$ Sep-90 & $<0.05$ & -0.1 & 0.7 \\
Tomatoes & $28-$ Sep-90 & $<0.05$ & -0.1 & 0.4 \\
Squash & 28-Sep-90 & $<0.05$ & -0.1 & 0.4 \\
Gourd & 28-Sep-90 & $<0.05$ & 0.0 & 0.4 \\
Potatoes & 28-Sep-90 & $<0.05$ & -0.1 & 0.4 \\
Cherry tomatoes & 30-Aug-90 & $<0.05$ & 0.1 & 0.5 \\
Potatoes & 25-Jul-90 & $<0.05$ & -0.1 & 0.4 \\
Green beans & 25-Jul-90 & $<0.05$ & -0.1 & 0.4 \\
Corn & 25-Jul-90 & $<0.05$ & -0.1 & 0.7 \\
Green beans & 30-May-90 & $<0.05$ & 0.0 & 0.6 \\
Tomatoes & 25-Jul-90 & $<0.05$ & 0.0 & 0.4 \\
Corn & 30-Aug-90 & $<0.05$ & 0.0 & 0.6 \\
Potatoes & 25-Jul-90 & $<0.05$ & 0.0 & 0.7 \\
Tomatoes & 25-Jul-90 & $<0.05$ & 0.0 & 0.4 \\
Potatoes & 25-Jul-90 & $<0.05$ & 0.1 & 0.4 \\
\hline
\end{tabular}


Table 5.2. 1990 fish samples

\begin{tabular}{lcccc}
\hline \multicolumn{1}{c}{ Location } & $\begin{array}{c}\text { Uranium } \\
(\mu \mathrm{g} / \mathrm{g})\end{array}$ & $\begin{array}{c}\text { Uranium } \\
\text { alpha } \\
(\mathrm{pCi} / \mathrm{g})\end{array}$ & $\begin{array}{c}\text { Technetium } \\
\text { beta } \\
(\mathrm{pCi} / \mathrm{g})\end{array}$ & $\begin{array}{c}\text { PCB } \\
(\mu \mathrm{g} / \mathrm{g})\end{array}$ \\
\hline X-611B (NPDES 005) & $<0.25$ & 1.3 & 0.0 & $<0.2$ \\
X-230J7 (NPDES 001) & $<0.25$ & 3.9 & 1.9 & 1.6 \\
X-230L (NPDES 009) & $<0.25$ & 2.6 & 5.4 & 1.8 \\
X-230J5 (NPDES 010) & $<0.25$ & 5.1 & 6.2 & 2.5 \\
X-2230ri (NPDES G002) & $<0.25$ & 2.5 & 6.2 & 0.9 \\
& & & & \\
Little Beaver Creek (U) & $<0.25$ & $<1.0$ & 0.0 & 0.4 \\
Little Beaver Creek (O) & $<0.25$ & 1.3 & 4.4 & 4.0 \\
Little Beaver Creek (O) & $<0.25$ & 1.3 & 3.0 & 1.2 \\
Little Beaver Creek (O) & $<0.25$ & 1.3 & 0.0 & 1.1 \\
Little Beaver Creek (O) & $<0.25$ & 3.7 & 1.0 & 2.2 \\
Little Beaver Creek (D) & $<0.25$ & 1.3 & 0.0 & 1.5 \\
Little Beaver Creek (D) & $<0.25$ & 10.3 & 10.9 & 3.8 \\
Little Beaver Creek (D) & $<0.25$ & 1.1 & 3.1 & 1.3 \\
Little Beaver Creek (D) & $<0.25$ & 0.0 & 5.9 & 1.6 \\
Little Beaver Creek (D-PL) & $<0.25$ & 4.2 & 1.1 & 0.5 \\
Little Beaver Creek (D-PL) & $<0.25$ & 2.5 & 7.4 & 2.1 \\
Little Beaver Creek (D-PL) & $<0.25$ & 0.0 & 6.6 & \\
Little Beaver Creek (D-PL) & $<0.25$ & 1.2 & 9.9 & 1.1 \\
Big Run Creek (D) & $<0.25$ & 1.3 & 7.4 & 0.4 \\
Big Run Creek (D) & $<0.25$ & 1.9 & 3.8 & \\
Big Run Creek (U) & $<0.25$ & 2.3 & 3.5 & \\
Scioto River (D) & $<0.25$ & 1.3 & 3.5 & \\
& & & & 0.2 \\
\hline
\end{tabular}

${ }^{a} U=U$ pstream from plant outfall; $\mathrm{O}=$ At or near plant outfall; $\mathrm{D}=$ Downstream from plant outfall; $\mathrm{D}-\mathrm{PL}=$ Downstream from the plant outfall and at or near the DOE property line. 
Table 5.3. 1990 vegetation (grass) samples

\begin{tabular}{|c|c|c|c|c|c|c|c|c|}
\hline \multirow[t]{2}{*}{ Location } & \multicolumn{2}{|c|}{$\begin{array}{c}\text { Uranium } \\
(\mu \mathrm{g} / \mathrm{g})\end{array}$} & \multicolumn{2}{|c|}{$\begin{array}{l}\text { Uranium alpha } \\
\qquad(\mathrm{pCi} / \mathrm{g})\end{array}$} & \multicolumn{2}{|c|}{$\begin{array}{l}\text { Technetium beta } \\
(\mathrm{pCi} / \mathrm{g})\end{array}$} & \multicolumn{2}{|c|}{$\begin{array}{c}\text { Fluorides } \\
(10, g)\end{array}$} \\
\hline & Spring & Fall & Spring & Fall & Spring & Fall & Spring & Fall \\
\hline \multicolumn{9}{|c|}{ On-site (DOE property line) } \\
\hline 3 & $<0.5$ & $<0.5$ & 0.3 & 0.3 & $<0.45$ & $<0.45$ & 3.4 & 2.0 \\
\hline 8 & $<0.5$ & $<0.5$ & 0.2 & -0.3 & $<0.45$ & $<0.45$ & 2.5 & 0.7 \\
\hline 9 & $<0.5$ & $<0.5$ & 0.0 & 0.2 & $<0.45$ & $<0.45$ & 0.3 & 3.0 \\
\hline $9 A$ & $<0.5$ & $<0.5$ & 0.3 & 0.3 & $<0.45$ & $<0.45$ & 0.9 & 1.1 \\
\hline 10 & $<0.5$ & $<0.5$ & -0.4 & 0.0 & $<0.45$ & $<0.45$ & 1.4 & 1.2 \\
\hline $10 A$ & $<0.5$ & $<0.5$ & -0.1 & 0.0 & $<0.45$ & $<0.45$ & 5.1 & 1.2 \\
\hline 11 & $<0.5$ & $<0.5$ & -0.3 & 0.2 & $<0.45$ & 0.4 & 4.3 & 2.8 \\
\hline 12 & $<0.5$ & $<0.5$ & -0.4 & -0.2 & $<0.45$ & $<0.45$ & 3.2 & 4.4 \\
\hline $12 \mathrm{~A}$ & $<0.5$ & $<0.5$ & C.3 & 0.0 & 0.5 & 0.4 & 2.7 & 1.7 \\
\hline 15 & $<0.5$ & $<0.5$ & 0.4 & 0.3 & $<0.45$ & 0.6 & 1.8 & 0.8 \\
\hline $15 \mathrm{~A}$ & $<0.5$ & $<0.5$ & -0.3 & $<0.8$ & $<0.45$ & $<0.8$ & 2.1 & 6.6 \\
\hline 23 & $<0.5$ & $<0.5$ & 0.0 & 2.3 & $<0.45$ & 2.3 & 2.8 & 6.0 \\
\hline 24 & $<0.5$ & $<0.5$ & 0.0 & $<0.8$ & $<0.45$ & $<0.8$ & 6.4 & 4.8 \\
\hline \multicolumn{9}{|c|}{ Off-site (up to $5 \mathrm{~km}$ off-site) } \\
\hline 13 & $<0.5$ & $<0.5$ & -0.6 & -0.6 & 0.8 & $<0.45$ & 1.1 & 3.4 \\
\hline 14 & $<0.5$ & $<0.5$ & 0.8 & 0.0 & $<0.45$ & 0.3 & 1.8 & 0.8 \\
\hline 16 & $<0.5$ & $<0.5$ & 0.3 & $<0.8$ & $<0.45$ & 0.1 & 3.5 & 3.8 \\
\hline 20 & $<0.5$ & $<0.5$ & -0.1 & $<0.8$ & $<0.45$ & 0.1 & 2.3 & 3.4 \\
\hline 27 & $<0.5$ & $<0.5$ & 0.0 & $<0.8$ & 0.2 & 0.0 & 0.5 & $<0.1$ \\
\hline 29 & $<0.5$ & $<0.5$ & 0.7 & $<0.8$ & $<0.45$ & 0.2 & 0.5 & 2.0 \\
\hline \multicolumn{9}{|c|}{ Remote (5 to $16 \mathrm{~km}$ off-site) } \\
\hline 1 & $<0.5$ & $<0.5$ & -0.4 & -0.1 & $<0.45$ & 0.8 & 2.1 & 7.0 \\
\hline 2 & $<0.5$ & $<0.5$ & 0.4 & 0.8 & $<0.45$ & 0.3 & 4.9 & 2.2 \\
\hline 4 & $<0.5$ & $<0.5$ & 0.4 & -0.2 & $<0.45$ & $<0.45$ & 1.0 & 4.4 \\
\hline 6 & $<0.5$ & -0.5 & 0.2 & 0.3 & $<0.45$ & $<0.45$ & 1.8 & 2.8 \\
\hline 17 & $<0.5$ & $<0.5$ & -0.1 & $<0.8$ & $<0.45$ & 0.2 & 3.4 & 3.6 \\
\hline 18 & $<0.5$ & $<0.5$ & 0.6 & $<0.8$ & $<0.45$ & 0.3 & 2.3 & 3.4 \\
\hline 19 & $<0.5$ & $<0.5$ & -0.2 & $<0.8$ & 1.7 & 0.2 & 2.2 & 4.0 \\
\hline 21 & $<0.5$ & $<0.5$ & -0.3 & $<0.8$ & $<0.45$ & 0.3 & 4.0 & 5.8 \\
\hline 22 & $<0.5$ & $<0.5$ & 0.3 & $<0.8$ & 0.8 & 0.1 & 3.3 & 4.2 \\
\hline 25 & $<0.5$ & $<0.5$ & 0.8 & $<0.8$ & 1.4 & 0.1 & 1.9 & 5.8 \\
\hline 26 & $<0.5$ & $<0.5$ & -0.3 & $<0.8$ & 0.2 & 0.0 & 1.7 & 3.1 \\
\hline 28 & $<0.5$ & $<0.5$ & -0.1 & 1.4 & 1.0 & 0.2 & 0.5 & $<0.1$ \\
\hline \multicolumn{9}{|c|}{ Background (16 km off-site) } \\
\hline SAV 10W & $<0.5$ & $<0.5$ & $<0.8$ & 0.3 & 0.1 & 0.4 & 0.6 & \\
\hline SAV 10E & $<0.5$ & $<0.5$ & 0.0 & $<0.8$ & 0.0 & 0.5 & 2.0 & 3.2 \\
\hline SAV 10N & $<0.5$ & $<0.5$ & 0.0 & $<0.8$ & $<0.45$ & 0.2 & 1.6 & 2.9 \\
\hline SAV IOS & $<0.5$ & $<0.5$ & 0.6 & $<0.8$ & 0.7 & 0.2 & 1.6 & 0.6 \\
\hline
\end{tabular}


6. SOIL AND SEDIMENT MONITORING 
Table 6.1. 1990 internal soll samples

\begin{tabular}{ccccrrr}
\hline Location & \multicolumn{2}{c}{$\begin{array}{c}\text { Uranium } \\
(\mu \mathrm{g} / \mathrm{g})\end{array}$} & \multicolumn{2}{c}{$\begin{array}{c}\text { Uranium alpha } \\
(\mathrm{pCi} / \mathrm{g})\end{array}$} & \multicolumn{2}{c}{$\begin{array}{c}\text { Technetium } \\
(\mathrm{pCi} / \mathrm{g})\end{array}$} \\
\hline & Spring & Fall & Spring & Fall & Spring & Fall \\
1 & 3.8 & 2.3 & 2.3 & 0.9 & 0.4 & 1.0 \\
3 & 3.1 & 3.9 & 2.3 & 5.9 & 0.5 & 8.0 \\
5 & 5.7 & 4.7 & 4.1 & 3.2 & 1.3 & 0.6 \\
12 & 5.7 & 4.0 & 3.6 & 8.6 & 1.0 & 3.5 \\
15 & 2.9 & 2.3 & 3.6 & 3.6 & 0.0 & 0.4 \\
17 & 3.3 & 0.8 & 1.8 & 1.8 & $<0.5$ & $<0.3$ \\
19 & 71.8 & 98.0 & 150.3 & 238.1 & 262.0 & 297.0 \\
22 & 4.5 & 8.6 & 7.2 & 13.5 & 3.5 & 21.0 \\
25 & 6.5 & 4.8 & 3.6 & 3.2 & 0.4 & 0.1 \\
26 & 4.3 & 4.7 & 3.2 & 6.3 & 0.7 & 2.0 \\
$26 \mathrm{~A}$ & 3.8 & 3.3 & 2.3 & 5.9 & 0.5 & 0.9 \\
32 & 7.1 & 5.5 & 4.5 & 4.1 & 1.1 & 0.2 \\
33 & 4.2 & 4.3 & 1.8 & 4.5 & 0.7 & 0.2 \\
34 & 4.7 & 6.3 & 0.5 & 5.0 & 3.0 & 1.5 \\
35 & 3.7 & 4.1 & 6.3 & 3.2 & 0.0 & 0.0 \\
36 & 2.5 & 2.7 & 5.0 & 4.5 & 0.4 & 1.0 \\
\hline
\end{tabular}


Table 6.2. 1990 external soll samples

\begin{tabular}{|c|c|c|c|c|c|c|}
\hline \multirow[t]{2}{*}{ Location } & \multicolumn{2}{|c|}{$\begin{array}{l}\text { Uranium } \\
(\mu \mathrm{g} / \mathrm{g})\end{array}$} & \multicolumn{2}{|c|}{$\begin{array}{l}\text { Uranium alpha } \\
\qquad(\mathrm{pCi} / \mathrm{g})\end{array}$} & \multicolumn{2}{|c|}{$\begin{array}{l}\text { Technetium } \\
(\mathrm{pCi} / \mathrm{g})\end{array}$} \\
\hline & Spring & Fall & Spring & Fall & Spring & Fall \\
\hline \multicolumn{7}{|c|}{ On-site (DOE property line) } \\
\hline S3 & 3.2 & 3.3 & 2.3 & 2.7 & 0.0 & $<0.45$ \\
\hline S8 & 4.5 & 1.4 & 3.2 & 3.2 & $<0.45$ & $<0.45$ \\
\hline S9 & 3.9 & 4.3 & 2.3 & 2.7 & 0.1 & $<0.45$ \\
\hline S9A & 3.3 & 5.9 & 1.8 & 3.6 & 0.1 & 0.1 \\
\hline $\mathrm{S} 10$ & 5.2 & 4.2 & 2.3 & 2.7 & $<0.45$ & 1.0 \\
\hline S10A & 5.9 & 3.4 & 4.1 & 1.8 & $<0.45$ & 0.2 \\
\hline S11 & 3.5 & 3.7 & 2.7 & 2.7 & 0.1 & 1.0 \\
\hline $\mathrm{S} 12$ & 4.6 & 2.7 & 2.7 & 2.7 & $<0.45$ & 1.0 \\
\hline S12A & 2.9 & 2.6 & 1.8 & 2.3 & 0.2 & 0.3 \\
\hline S15 & 5.5 & 3.7 & 1.8 & 2.3 & $<0.45$ & 0.2 \\
\hline S15A & 3.8 & 2.1 & 3.6 & 2.7 & $<0.45$ & 0.2 \\
\hline$\$ 23$ & 4.3 & 2.3 & 1.4 & 2.7 & $<0.45$ & $<0.45$ \\
\hline S24 & 4.0 & 2.4 & 5.0 & 1.4 & 0.0 & $<0.45$ \\
\hline \multicolumn{7}{|c|}{ Off-site (up to $5 \mathrm{~km}$ off-site) } \\
\hline S13 & 4.9 & 2.6 & 0.5 & 1.4 & 4.0 & 2.0 \\
\hline S14 & 4.1 & 4.5 & 2.3 & 1.8 & $<0.45$ & 0.0 \\
\hline S16 & 4.4 & 2.9 & 3.6 & 1.8 & $<0.45$ & 0.1 \\
\hline S20 & 2.7 & 1.6 & 1.8 & 0.9 & $<0.45$ & 0.0 \\
\hline S27 & 3.4 & 6.0 & 3.6 & 3.6 & $<0.45$ & 0.1 \\
\hline $\mathrm{S} 29$ & 3.2 & 5.5 & 2.3 & 3.2 & $<0.45$ & 0.0 \\
\hline \multicolumn{7}{|c|}{ Remote ( 5 to $16 \mathrm{~km}$ off-site) } \\
\hline $\mathrm{S} 1$ & 2.9 & 5.7 & 2.3 & 4.5 & $<0.45$ & 1.0 \\
\hline S2 & 3.1 & 3.3 & 1.4 & 2.3 & $<0.45$ & -0.45 \\
\hline S4 & 5.6 & 1.8 & 2.7 & 1.8 & 0.1 & 0.0 \\
\hline S6 & 8.4 & 2.7 & 4.1 & 4.5 & 1.0 & 1.0 \\
\hline S17 & 5.6 & 2.8 & $<0.45$ & 2.3 & $<0.45$ & 0.1 \\
\hline S18 & 3.5 & 2.4 & 2.3 & 1.8 & $<0.45$ & 0.3 \\
\hline S19 & 1.7 & 2.0 & 3.2 & 3.2 & $<0.45$ & $<0.45$ \\
\hline $\mathrm{S} 21$ & 5.9 & 1.7 & 1.8 & 3.6 & $<0.45$ & 1.1 \\
\hline $\mathrm{S} 22$ & 1.8 & 3.0 & 1.8 & 4.1 & $<0.45$ & 1.0 \\
\hline $\mathrm{S} 25$ & 2.9 & 0.8 & 3.2 & 3.6 & $<0.45$ & 1.0 \\
\hline S26 & 5.7 & 6.3 & 6.3 & 4.1 & $<0.45$ & 1.0 \\
\hline S28 & 4.7 & 2.6 & 4.1 & 3.2 & $<0.45$ & 0.8 \\
\hline \multicolumn{7}{|c|}{ Background (16 km off-site) } \\
\hline RS10W & 9.7 & 4.0 & 5.0 & 3.6 & 5.0 & 2.0 \\
\hline RS10E & 1.0 & 3.0 & 0.5 & 3.6 & $<0.45$ & 0.5 \\
\hline RS10N & 3.7 & 4.1 & 3.6 & 1.8 & $<0.45$ & 0.8 \\
\hline রS10S & 6.2 & 2.1 & 1.8 & 1.4 & $<0.45$ & $<0.45$ \\
\hline
\end{tabular}


Table 6.3. 1990 stream sediment samples

\begin{tabular}{|c|c|c|c|c|c|c|}
\hline \multirow[t]{2}{*}{ Location } & \multicolumn{2}{|c|}{$\begin{array}{l}\text { Uranium } \\
(\mu \mathrm{g} / \mathrm{g})\end{array}$} & \multicolumn{2}{|c|}{$\begin{array}{l}\text { Uranium alpha } \\
(\mathrm{pCi} / \mathrm{g})\end{array}$} & \multicolumn{2}{|c|}{$\begin{array}{l}\text { Technetium } \\
\text { (pCi/g) }\end{array}$} \\
\hline & Spring & Fall & Spring & Fall & Spring & Fall \\
\hline \multicolumn{7}{|c|}{ On-sise outfalls } \\
\hline $\begin{array}{l}\text { Southwest Holding } \\
\text { Pond (RM9) }\end{array}$ & 3.9 & 2.2 & 2.3 & 4.5 & $<0.45$ & 0.0 \\
\hline $\begin{array}{l}\text { West Drainage } \\
\text { Ditch (RM10) }\end{array}$ & 3.3 & 2.1 & 1.8 & 2.3 & 1.0 & 0.1 \\
\hline $\begin{array}{l}\text { East Drainage } \\
\text { Ditch (RM11) }\end{array}$ & 16.5 & 13.6 & 43.7 & 5.9 & 42.0 & 1.2 \\
\hline \multicolumn{7}{|c|}{ Little Beaver Creek } \\
\hline RM12 & 1.5 & 4.7 & 2.3 & 0.9 & $<0.45$ & 0.0 \\
\hline RM8 & 9.9 & 9.3 & 32.0 & 19.8 & 41.8 & 17.0 \\
\hline RM7 & 5.2 & 4.4 & 6.8 & 8.6 & 22.7 & 17.0 \\
\hline \multicolumn{7}{|c|}{ Big Beaver Creek } \\
\hline RM5 & 3.3 & 3.9 & 3.2 & 1.4 & 1.2 & 0.6 \\
\hline RM13 & 5.2 & 5.8 & 9.0 & $\begin{array}{r}1.4 \\
18.9\end{array}$ & 18.3 & 34.0 \\
\hline \multicolumn{7}{|c|}{ Big Run Creek } \\
\hline RM33 & 4.8 & 1.1 & 2.3 & 2.7 & $<0.45$ & 0.0 \\
\hline RM3 & 6.5 & 5.4 & 6.3 & 10.4 & 2.1 & 1.6 \\
\hline RM3A & 6.3 & 5.8 & 9.9 & 7.7 & 1.0 & 1.0 \\
\hline RM2 & 5.7 & 3.7 & 3.2 & 3.2 & $<0.45$ & 0.5 \\
\hline \multicolumn{7}{|c|}{ Scioto River } \\
\hline RM6 & 1.6 & 3.7 & 1.3 & 4.5 & $<0.45$ & 0.0 \\
\hline RM1 & 2.3 & 4.5 & 2.3 & 3.2 & $<0.45$ & 0.2 \\
\hline \multicolumn{7}{|c|}{ Background } \\
\hline RM10W & 5.8 & 3.9 & 3.2 & 4.5 & $<0.45$ & $<0.45$ \\
\hline RM10S & 3.3 & 4.5 & 1.8 & 2.7 & $<0.45$ & $<0.45$ \\
\hline RM10E & 7.0 & 1.7 & $<0.5$ & 2.3 & $<0.45$ & $<0.45$ \\
\hline RMION & 3.5 & 1.3 & 2.7 & 1.4 & $<0.45$ & $<0.45$ \\
\hline
\end{tabular}


7. POTENTIAL RADIATION AND CHEMICAL DOSE TO THE PUBLIC 
Table 7.1. Effective dose rate conversion factors ${ }^{a}$

\begin{tabular}{|c|c|c|c|c|}
\hline $\begin{array}{l}\text { Radionuclide } \\
\text { (solubility) }\end{array}$ & $\begin{array}{l}\text { Inhalation } \\
(\mathrm{rem} / \mu \mathrm{Ci})\end{array}$ & $\begin{array}{l}\text { Ingestion } \\
(\mathrm{rem} / \mu \mathrm{Ci})\end{array}$ & $\begin{array}{c}\text { Immersion } \\
(\mathrm{mrem} / \text { year } \\
\left.\text { per } \mu \mathrm{Ci} / \mathrm{cm}^{3}\right)\end{array}$ & $\begin{array}{c}\text { Ground surfaces } \\
(\mathrm{mrem} / \mathrm{year} \\
\left.\text { per } \mu \mathrm{Ci} / \mathrm{cm}^{2}\right)\end{array}$ \\
\hline${ }^{99} \mathrm{Tc}(\mathrm{D})^{b}$ & $1.03 \times 10^{-3}$ & $1.45 \times 10^{-3}$ & $2.55 \times 10^{3}$ & $6.03 \times 10^{-1}$ \\
\hline${ }^{234} U(D)$ & 2.67 & $2.74 \times 10^{-1}$ & $7.46 \times 10^{5}$ & $8.00 \times 10^{2}$ \\
\hline${ }^{235} \mathrm{U}$ (D) & 2.54 & $2.64 \times 10^{-1}$ & $7.51 \times 10^{8}$ & $1.67 \times 10^{5}$ \\
\hline${ }^{236} \mathrm{U}$ (D) & 2.53 & $2.60 \times 10^{-1}$ & $5.90 \times 10^{5}$ & $7.27 \times 10^{2}$ \\
\hline${ }^{238} \mathrm{U}$ (D) & 2.40 & $2.47 \times 10^{-1}$ & $5.06 \times 10^{5}$ & $6.41 \times 10^{2}$ \\
\hline${ }^{231} \mathrm{Th}(\mathrm{W})$ & $9.62 \times 10^{-4}$ & $1.35 \times 10^{-3}$ & $5.82 \times 10^{1}$ & 1.91 \\
\hline${ }^{234} \mathrm{Th}(\mathrm{W})$ & $3.06 \times 10^{-2}$ & $1.37 \times 10^{-2}$ & $3.73 \times 10^{7}$ & $9.71 \times 10^{3}$ \\
\hline${ }^{234 m} \mathrm{~Pa}(\mathrm{~W})$ & $3.77 \times 10^{-6}$ & $5.90 \times 10^{-6}$ & $5.93 \times 10^{7}$ & $1.12 \times 10^{4}$ \\
\hline
\end{tabular}

${ }^{a}$ Factors taken from the ALLRAD88 data file provided with CAP-88.

${ }^{b} \mathrm{D}$-soluble in blood; $\mathrm{W} \longrightarrow$ moderately soluble in blood.

Table 7.2. Release point parameters and receptor locations used in the dose calculations

\begin{tabular}{ccccccc}
\hline Name & Type & $\begin{array}{c}\text { Release } \\
\text { height } \\
(\mathrm{m})\end{array}$ & $\begin{array}{c}\text { Inner } \\
\text { diameter } \\
(\mathrm{m})\end{array}$ & $\begin{array}{c}\text { Gas exit } \\
\text { velocity } \\
(\mathrm{m} / \mathrm{s})\end{array}$ & $\begin{array}{c}\text { Gas exit } \\
\text { temperature } \\
\left({ }^{\circ} \mathrm{C}\right)\end{array}$ & $\begin{array}{c}\text { Distance (m) } \\
\text { and direction } \\
\text { to maximally } \\
\text { exposed individual }\end{array}$ \\
\hline Stack 1 & Point & 50 & 0.24 & 0.04 & Ambient & $1770 \mathrm{ENE}$ \\
Stack 2 & Point & 20 & 0.24 & 0.04 & Ambient & $1770 \mathrm{ENE}$ \\
Stack 3 & Point & 3 & 0.24 & 0.04 & Ambient & $1770 \mathrm{ENE}$ \\
\hline
\end{tabular}

aThe maximally exposed individual is assumed to live at a plant boundary. 
Table 7.3. Activities (Ci), solubilities, and AMAD ( $\mu \mathrm{m})$ of radionuclides emitted from PORTS during 1990

\begin{tabular}{|c|c|c|c|c|c|c|}
\hline \multirow{2}{*}{ Nuclide } & \multirow{2}{*}{$\begin{array}{l}\text { Solubilities } \\
\text { class }\end{array}$} & \multirow{2}{*}{$\begin{array}{c}\text { AMAD } \\
(\mu \mathrm{m})\end{array}$} & \multicolumn{4}{|c|}{ Curies $(\mathrm{Ci})$ released during 1990} \\
\hline & & & Stack 1 & Stack 2 & Stack 3 & Total \\
\hline${ }^{234} U$ & D & 1.0 & $2.94 \mathrm{E}-2$ & $8.65 E-3$ & $9.10 \mathrm{E}-4$ & $3.90 \mathrm{E}-2$ \\
\hline${ }^{235} \mathrm{U}$ & D & 1.0 & $9.51 \mathrm{E}-4$ & $1.46 \mathrm{E}-4$ & $2.25 \mathrm{E}-5$ & $1.13 \mathrm{E}-3$ \\
\hline${ }^{236} \mathrm{U}$ & $\mathrm{D}$ & 1.0 & $5.20 \mathrm{E}-6$ & $7.6,9 \mathrm{E}-7$ & $8.28 \mathrm{E}-8$ & $6.05 \mathrm{E}-6$ \\
\hline${ }^{238} \mathrm{U}$ & $\mathrm{D}$ & 1.0 & $4.06 \mathrm{E}-4$ & $1.15 \mathrm{E}-3$ & $7.26 \mathrm{E}-7$ & $1.56 \mathrm{E}-3$ \\
\hline${ }^{99} \mathrm{Tc}$ & $\mathrm{D}$ & 1.0 & $3.70 \mathrm{E}-2$ & $1.03 \mathrm{E}-2$ & $2.12 \mathrm{E}-3$ & $4.94 \mathrm{E}-2$ \\
\hline${ }^{231} \mathrm{Th}$ & $\mathrm{w}$ & 1.0 & $9.51 \mathrm{E}-4$ & $1.46 \mathrm{E}-4$ & $2.25 \mathrm{E}-5$ & $1.12 \mathrm{E}-3$ \\
\hline${ }^{234} \mathrm{Th}$ & W & 1.0 & $4.06 \mathrm{E}-4$ & $1.15 \mathrm{E}-3$ & $2.25 \mathrm{E}-5$ & $1.58 \mathrm{E}-3$ \\
\hline $234 \mathrm{mPa}$ & W & 1.0 & $4.06 E-4$ & $1.15 \mathrm{E}-3$ & $2.25 \mathrm{E}-5$ & $1.58 \mathrm{E}-3$ \\
\hline
\end{tabular}

Table 7.4. Predicted doses from 1990 airborne releases at Portsmouth

\begin{tabular}{ll}
\hline \multicolumn{1}{c}{ Dose to } & EDE \\
\hline Nearest residen $^{a}$ & 0.06 \\
Population $^{b}$ & 0.4 \\
Nearest community $^{c}$ & 0.008 \\
\hline
\end{tabular}

aNearest resident is $1770 \mathrm{~m}$ ENE.

Dose in mrem.

${ }^{b}$ Dose to popuiation within $80 \mathrm{~km}$.

Dose in person-rem.

'Piketon is nearest community.

Dose in person-rem.

Table 7.5. Doses from aquatic pathways in the Scloto River

\begin{tabular}{cc}
\hline & $\begin{array}{c}\text { Effective jose equivalent } \\
\text { (mrem) }\end{array}$ \\
\hline Eating fish ${ }^{a}$ & 0.0009 \\
Drinking water & 0.001 \\
\cline { 2 - 2 } Total & 0.002 \\
\hline${ }^{a}$ Assumed consumption of $21 \mathrm{~kg}$ of fish per year. \\
${ }^{b}$ Assumed consumption of $730 \mathrm{~L}$ of water per year.
\end{tabular}




\section{SOLID WASTE MANAGEMENT PROGRAM}




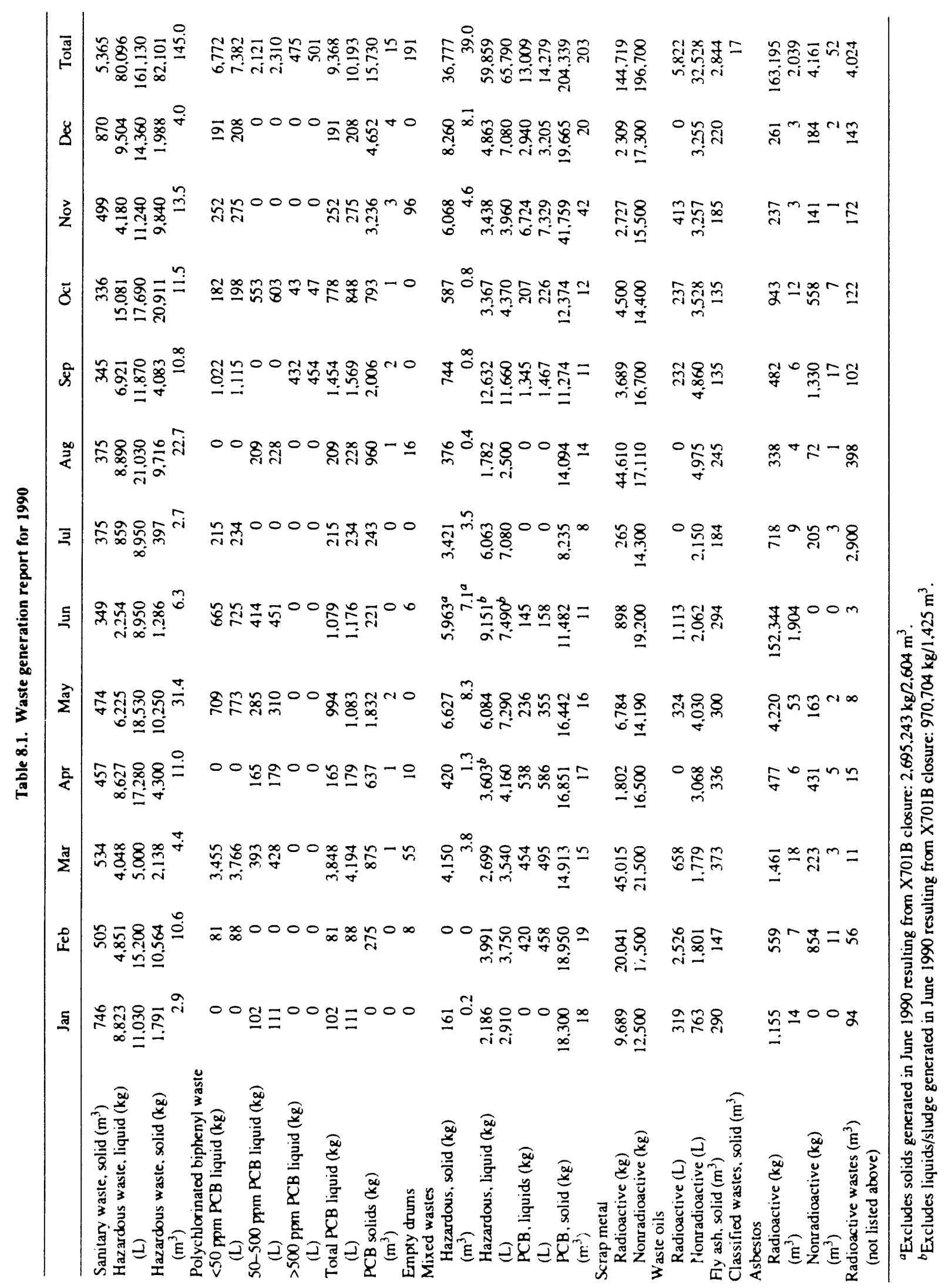




\section{SPECIAL STUDIES}


All information for this section is presented in Part 1. 


\section{QUALITY ASSURANCE}


Table 10.1. Martin Marietta Energy Systems, Inc. (PORTS), environmental analysis procedures for water

\begin{tabular}{|c|c|c|c|}
\hline \multirow[t]{2}{*}{ Parameter } & \multicolumn{2}{|c|}{ Procedure } & \multirow{2}{*}{$\begin{array}{l}\text { Lowest concentration } \\
\text { reported }(\mathrm{LCR})^{b}\end{array}$} \\
\hline & $\mathrm{ES}^{a}$ & EPA & \\
\hline Alpha activity (uranium) & EC-033-PORTS & & $2.0 \mathrm{pCi} / \mathrm{L}$ \\
\hline Alpha activity (gross) & EC-034 PORTS & & $2.0 \mathrm{pCi} / \mathrm{L}$ \\
\hline Beta activity (gross) & EC-035 PORTS & & $4.0 \mathrm{pCi} / \mathrm{L}$ \\
\hline Arsenic & & 206.2 & 0.02 \\
\hline Asbestos & & $600 / 4-83-043$ & $1.34 \times 10^{5}$ fibers $/ \mathrm{L}$ \\
\hline Barium & & $208.1 / 200.7 / 6010$ & $0.4 / 0.2 / 0.2 \mathrm{mg} / \mathrm{L}$ \\
\hline BOD (5d) & QTS-511E-029-0 & & $5 \mathrm{mg} / \mathrm{L}$ \\
\hline Cadmium (total) & & $213.1 / 200.7 / 6010$ & $0.02 / 0.01 / 0.01 \mathrm{mg} / \mathrm{L}$ \\
\hline Carbitol & & 8270 & $10 \mu \mathrm{g} / \mathrm{L}$ \\
\hline Carhon (organic, total) & & 9060 & $1 \mathrm{mg} / \mathrm{L}$ \\
\hline Chloride & QTS-511E-032-0 & & $1 \mathrm{mg} / \mathrm{L}$ \\
\hline Chlorine (total, residual) & QTS-511E-058-0 & & $0.02 \mathrm{mg} / \mathrm{L}$ \\
\hline Chlorinated solvent scan & & 8010 & $1 \mu \mathrm{g} / \mathrm{L}$ \\
\hline Chromium (total) & & $218.1 / 200.7 / 6010$ & $0.1 / 0.02 / 0.03 \mathrm{mg} / \mathrm{L}$ \\
\hline Chromium (VI) & EC-009 PORTS & & $0.01 \mathrm{mg} / \mathrm{L}$ \\
\hline Coliform bacteria (fecal) & QTS-511E-043-0 & & $<1$ colony $/ 100 \mathrm{~mL}$ \\
\hline Coliform bacteria & QTS-511E-028-0 & & $<1$ colony $/ 100 \mathrm{~mL}$ \\
\hline Copper (total) & & $220.1 / 200.7$ & $0.05 / 0.01 \mathrm{mg} / \mathrm{L}$ \\
\hline 2,4-D & & 8150 & $1 \mu \mathrm{g} / \mathrm{L}$ \\
\hline Endrin & & 8080 & $1 \mu \mathrm{g} / \mathrm{L}$ \\
\hline Fluoride & & 340.2 & $0.1 \mathrm{mg} / \mathrm{L}$ \\
\hline $\begin{array}{l}\text { Freon-113 } \\
\text { Gamma emitters }\end{array}$ & EC-039 PORTS & 8010 & $\begin{array}{l}1 \mu \mathrm{g} / \mathrm{L} \\
2.5 \mathrm{pCi} / \mathrm{L}\end{array}$ \\
\hline Halogen (organic, total) & & 9020 & $5 \mu \mathrm{g} / \mathrm{L}$ \\
\hline Halogenated volatile organics & & 8010 & $1 \mu \mathrm{g} / \mathrm{L}$ \\
\hline Iron (total) & & $236.1 / 200.7 / 6010$ & $0.05 / 0.04 / 0.04 \mathrm{mg} / \mathrm{L}$ \\
\hline Lead (total) & & $239.1 / 200.7 / 6010$ & $0.1 / 0.05 / 0.05 \mathrm{mg} / \mathrm{L}$ \\
\hline Lindane & & $8080^{\circ}-(-2)$ & $1 \mu \mathrm{g} / \mathrm{L}$ \\
\hline Manganese (total) & & $243.1 / 200.7 / 6010$ & $0.03 / 0.02 / 0.03 \mathrm{mg} / \mathrm{L}$ \\
\hline Mercury & & 245.1 & $0.5 \mu \mathrm{g} / \mathrm{L}$ \\
\hline $\begin{array}{l}\text { Methoxychlor } \\
{ }^{237} \mathrm{~Np}\end{array}$ & EC-038 PORTS & 8080 & $\begin{array}{l}1 \mu \mathrm{g} / \mathrm{L} \\
1.0 \mathrm{pCi} / \mathrm{L}\end{array}$ \\
\hline Nickel (total) & & $249.1 / 200.7 / 6010$ & $0.1 / 0.02 / 0.05 \mathrm{mg} / \mathrm{L}$ \\
\hline Nitrogen (ammonia) & & 350.3 & $0.1 \mathrm{mg} / \mathrm{L}$ \\
\hline Nitrogen (nitrate-nitrite) & & 353.3 & $0.2 \mathrm{mg} / \mathrm{L}$ \\
\hline Nitrogen, Kjeldahl (total) & & 351.4 & $0.1 \mathrm{mg} / \mathrm{L}$ \\
\hline Oil and grease & & 413.1 & $5 \mathrm{mg} / \mathrm{L}$ \\
\hline $\begin{array}{l}\mathrm{PCB} \text { (scan) } \\
\mathrm{pH}\end{array}$ & & $\begin{array}{l}608 / 8080 \\
150.1\end{array}$ & $\begin{array}{l}1 \mu \mathrm{g} / \mathrm{L} \\
\text { Nearest } 0.1 \mathrm{pH} \\
\text { unit }\end{array}$ \\
\hline Phosphate (all forms) & & 365.2 & $0.1 \mathrm{mg} / \mathrm{L}$ \\
\hline Phenols & & 8040 & $1-10 \mu \mathrm{g} / \mathrm{L}$ \\
\hline Plutonium & EC-038 PORTS & & $1.0 \mathrm{pCi} / \mathrm{L}$ \\
\hline Radium & & 900.1 & $4.0 \mathrm{pCi} / \mathrm{L}$ \\
\hline
\end{tabular}


Table 10.1 (Continued)

\begin{tabular}{llll}
\hline \multicolumn{1}{c}{ Parameter } & \multicolumn{2}{c}{ Procedure } & $\begin{array}{c}\text { Lowest concentration } \\
\text { reported (LCR) }\end{array}$ \\
\cline { 2 - 4 } & \multicolumn{1}{c}{ ES $^{a}$} & EPA & \\
\hline Selenium (total) & & $270.2 / 200.7$ & $0.02 / 0.2 \mathrm{mg} / \mathrm{L}$ \\
Silver (total) & & $272.1 / 200.7 / 6010$ & $0.06 / 0.05 / 0.1 \mathrm{mg} / \mathrm{L}$ \\
Sodium (total) & & $273.1 / 200.7 / 6010$ & $0.01 / 0.1 / 0.1 \mathrm{mg} / \mathrm{L}$ \\
Solids (dissolved) & & 160.1 & $1 \mathrm{mg} / \mathrm{L}$ \\
Solids (suspended) & & 160.2 & $1 \mathrm{mg} / \mathrm{L}$ \\
Solids (total) & & 160.3 & $10 \mathrm{mg} / \mathrm{L}$ \\
Sulfate & QTS-511E-049-1 & & $1 \mathrm{mg} / \mathrm{L}$ \\
99Tc & EC-038-PORTS & 601 & $300 \mathrm{pCi} / \mathrm{L}$ \\
Tetrachloroethane & & & $1 \mu \mathrm{g} / \mathrm{L}$ \\
Thorium & EC-037 PORTS & 8080 & $4 \mathrm{pCi} / \mathrm{L}$ \\
Toxaphene & & 8270 & $10 \mu \mathrm{g} / \mathrm{L}$ \\
Tributyl phosphate & & 601 & $10 \mu \mathrm{g} / \mathrm{L}$ \\
1,1,1-Trichloroethane & & $601 / 8010$ & $1 \mu \mathrm{g} / \mathrm{L}$ \\
Trichloroethylene & & 8150 & $1 \mu \mathrm{g} / \mathrm{L}$ \\
2,4,5 TP Silvex & & 180.1 & $1 \mu \mathrm{g} / \mathrm{L}$ \\
Turbidity & & & $0.05 \mathrm{NTU}$ \\
Uranium (total) & & 8240 & $1 \mu \mathrm{g} / \mathrm{L}$ \\
Volatile organics & & $289.1 / 200.7 / 6010$ & $1-100 \mu \mathrm{g} / \mathrm{L}$ \\
Zinc (total) & & & $0.02 / 0.06 / 0.06 \mathrm{mg} / \mathrm{L}$ \\
\hline
\end{tabular}

aProcedures described in:

1. Works Laboratory Procedures Manual, GAT-115, rev. 3, Vols. I and II, Goodyear Atomic Corp., Piketon, Ohio.

2. Determination of Trace Elements in Uranium Compounds-Specification Analyses. GAT-507, Goodyear Atomic Corp., Piketon, Ohio, 1968.

3. Hesse, P. R., A Textbook of SOIL Chemical Analysis, Chemical Publishing Co., New York, 1972.

4. Environmental Control-Analytical Procedure Manual, POEF 1192, Vol. 3, Martin Marietta Energy Systems, Portsmouth Gaseous Diffusion Plant, Piketon, Ohio.

${ }^{b}$ The LCR may vary among specific samples, depending on interferences in the sample matrix. However, these LCRs have been assigned to accommodate most minor interferences. Some of the Energy Systems LCRs are higher than the method detection limits (MDLs) listed by EPA. This is consistent with guidance from EPA; however, any data reported below the MDLs must be supported by sound documentation. The LCRs applied by Energy Systems laboratories meet the needs of the programs they support. 
Table 10.2. Martin Marietta Energy Systems, Inc. (PORTS), environmental analysis procedures for air

\begin{tabular}{|c|c|c|c|}
\hline \multirow{2}{*}{ Parameter } & \multicolumn{2}{|c|}{ Procedure } & \multirow{2}{*}{$\begin{array}{l}\text { Lowest concentration } \\
\text { reported }(\mathrm{LCR})^{b}\end{array}$} \\
\hline & $\mathrm{ES}^{a}$ & EPA & \\
\hline \multicolumn{4}{|l|}{ AA membrane filters } \\
\hline $\begin{array}{l}\text { Alpha activity } \\
\text { Beta activity }\end{array}$ & EC-102 PORTS & & $1.2 \mathrm{pCi} / \mathrm{sample}$ \\
\hline Beta activity & EC-102 PORTS & & \\
\hline Fluoride & EC-100 PORTS & & $2.5 \mu \mathrm{g} / \mathrm{sample}$ \\
\hline Asbestos & $\begin{array}{l}\text { NIOSH Method } 7400 \\
(5-15-89)\end{array}$ & & $\begin{array}{l}7 \text { fibers } / \mathrm{mm}^{2} \\
\text { filter area }\end{array}$ \\
\hline \multicolumn{4}{|l|}{ Cascade vents } \\
\hline $\begin{array}{l}\text { Alpha activity } \\
\text { Fluoride }\end{array}$ & 2-G-35-0 & & $20 \mathrm{pCi} / \mathrm{sample}$ \\
\hline Grab samples & $2-J-302-1$ & & $5 \mu \mathrm{g} /$ sample \\
\hline Continuous samples & $\begin{array}{l}\text { QTS-523-002-0 } \\
\text { OTS-523-003-0 }\end{array}$ & & $0.5 \mathrm{mg} / \mathrm{sample}$ \\
\hline \multirow[t]{2}{*}{${ }^{99} \mathrm{Tc}$} & $2-G-25-2$ & & $300 \mathrm{pCi} / \mathrm{sample}$ \\
\hline & 2-G-34-0 & & $0.02 \mu \mathrm{g} / \mathrm{sample}$ \\
\hline \multirow[t]{2}{*}{ Uranium } & $2-\mathrm{G}-34-0$ & & $2.5 \mu \mathrm{g} / \mathrm{sample}$ \\
\hline & $2-\mathrm{J}-22-1$ & & $0.25 \mu \mathrm{g} / \mathrm{sample}$ \\
\hline${ }^{235} \mathrm{U}$ & $2-G-34-0$ & & $2.0 \mu \mathrm{g} / \mathrm{sample}$ \\
\hline
\end{tabular}

aProcedures described in:

1. Works Laboratory Procedures Manual, GAT-115, rev. 3, Vols. I and II, Goodyear Atomic Corp., Piketon, Ohio.

2. Determination of Trace Elements in Uranium Compounds Specification Analyses. GAT-507, Goodyear Atomic Corp., Piketon, Ohio, 1968.

3. Hesse, P. R., A Textbook of SOIL Chemical Analysis, Chemical Publishing Co., New York, 1972.

4. Environmental Control-Analytical Procedure Manual, POEF 1192, Vol. 2, Martin Marietta Energy Systems, Portsmouth Gaseous Diffusion Plant, Piketon, Ohio.

${ }^{b}$ The LCR may vary among specific samples, depending on interferences in the sample matrix. However, these LCRs have been assigned to accommodate most minor interferences. Some of the Energy Systems LCRs are higher than the method detection limits (MDLs) listed by EPA. This is 
Table 10.3. Martin Marietta Energy Systems, Inc. (PORTS), environmental analysis procedures for soil and sediment

\begin{tabular}{|c|c|c|c|}
\hline \multirow{2}{*}{ Parameter } & \multicolumn{2}{|c|}{ Procedure } & \multirow{2}{*}{$\begin{array}{l}\text { Lowest concentration } \\
\text { reported }(\mathrm{LCR})^{b}\end{array}$} \\
\hline & $\mathrm{ES}^{a}$ & EPA & \\
\hline \multirow[t]{2}{*}{ Alpha activity (uranium) } & $2-G-35-0$ & & $1.4 \times 10^{3} \mathrm{pCi} / \mathrm{kg}$ \\
\hline & EC-204-PORTS & & $1 \times 10^{4} \mathrm{pCi} / \mathrm{kg}$ \\
\hline Fluoride & EC-201-PORTS & & NA \\
\hline Mercury (total) & EC-202 PORTS & & NA \\
\hline $\begin{array}{c}\text { Metals (Al, Ba, Be, Ca, } \\
\text { Col, Co, Cr, Cu, Fe, } \\
\text { Pb, Mg, Mo, Ni, K, } \\
\text { Na, Tl, V, Zn) }\end{array}$ & $3050 / 6010$ & & NA \\
\hline Nitrates & $a(3)$ & & NA \\
\hline PCB (scan) & & 8080 & $0.4 \mathrm{mg} / \mathrm{kg}$ \\
\hline Phosphate & $a(3)$ & & NA \\
\hline $\mathrm{pH}$ & & 9040 & $\begin{array}{l}\text { Nearest } 0.1 \mathrm{pH} \\
\text { unit }\end{array}$ \\
\hline${ }^{99} \mathrm{Tc}$ & $2-G-26-2$ & & $2 \times 10^{4} \mathrm{pCi} / \mathrm{kg}$ \\
\hline Uranium (total) & EC-203-PORTS & & $1 \mathrm{mg} / \mathrm{kg}$ \\
\hline
\end{tabular}

aprocedures described in:

1. Works Laboratory Procedures Manual, GAT-115, rev. 3, Vols. I and II, Goodyear Atomic Corp., Piketon, Ohio.

2. Determination of Trace Elements in Uranium Compounds-Specification Analyses. GAT-507, Goodyear Atomic Corp., Piketon, Ohio, 1968.

3. Hesse, P. R., A Textbook of SOIL Chemical Analysis, Chemical Publishing Co., New York, 1972.

4. Environmental Control-Analytical Procedure Manual, POEF 1192, Vol. 2, Martin Marietta Energy Systems, Portsmouth Gaseous Diffusion Plant, Piketon, Ohio.

${ }^{b}$ The LCR may vary among specific samples, depending on interferences in the sample matrix. However, these LCRs have been assigned to accommodate most minor interferences. Some of the Energy Systems LCRs are higher than the method detection limits (MDLs) listed by EPA. This is consistent with guidance from EPA; however, any data reported below the MDLs must be supported by sound documentation. The LCRs applied by Energy Systems laboratorics meet the needs of the programs they support. 
Table 10.4. Martin Marietta Energy Systems, Inc. (PORTS), environmental analysis procedures for biota

\begin{tabular}{|c|c|c|c|}
\hline \multirow{2}{*}{ Parameter } & \multicolumn{2}{|c|}{ Procedure } & \multirow{2}{*}{$\begin{array}{l}\text { Lowest concentration } \\
\text { reported }(\text { LCR })^{b}\end{array}$} \\
\hline & $\mathrm{ES}^{a}$ & EPA & \\
\hline \multicolumn{4}{|l|}{ Vegetation and vegetables } \\
\hline Alpha activity (uranium) & EC-204-PORTS & & $5.3 \times 10^{2} \mathrm{pCi} / \mathrm{kg}$ \\
\hline Fluoride & EC-300-PORTS & & $1 \mathrm{mg} / \mathrm{kg}$ \\
\hline PCB (scan) & & 8080 & $0.4 \mathrm{mg} / \mathrm{kg}$ \\
\hline${ }^{99} \mathrm{Tc}$ & $2-G-26-2$ & & $3.5 \times 10^{3} \mathrm{pCi} / \mathrm{kg}$ \\
\hline Uranium (total) & EC-301-PORTS & & $0.5 \mathrm{mg} / \mathrm{kg}$ \\
\hline \multicolumn{4}{|l|}{ Milk } \\
\hline Alpha activity (uranium) & EC-204-PORTS & & $10 \mathrm{pCi} / \mathrm{L}$ \\
\hline Technetium & $2-G-26-2$ & & $4.5 \times 10^{2} \mathrm{pCi} / \mathrm{L}$ \\
\hline Uranium (total) & EC-302-PORTS & & $0.01 \mathrm{mg} / \mathrm{L}$ \\
\hline \multicolumn{4}{|l|}{ Fish } \\
\hline Arsenic & EC-303-PORTS & & $0.5 \mathrm{mg} / \mathrm{kg}$ \\
\hline Mercury & EC-304-PORTS & & $0.05 \mathrm{mg} / \mathrm{kg}$ \\
\hline PCB (scan) & & 8080 & $0.2 \mathrm{mg} / \mathrm{kg}$ \\
\hline Selenium & EC-305-PORTS & & $0.1 \mathrm{mg} / \mathrm{kg}$ \\
\hline Uranium & $2-\mathrm{J}-145-1$ & & $0.25 \mathrm{mg} / \mathrm{kg}$ \\
\hline
\end{tabular}

aprocedures described in:

1. Works Laboratory Procedures Manual, GAT-115, rev. 3, Vols. I and II, Goodyear Atomic Corp., Piketon, Ohio.

2. Determination of Trace Elements in Uranium Compounds-Specification Analyses. GAT-507. Goodyear Atomic Corp., Piketon, Ohio, 1968.

3. Hesse, P. R., A Textbook of SOIL Chemical Analysis, Chemical Publishing Co., New York, 1972.

4. Environmensal Control-Analytical Procedure Manual, PCEF 1192, Vol. 2, Martin Marietta Energy Systems, Portsmouth Gaseous Diffusion Plant, Piketon, Ohio.

bThe LCR may vary among specific samples, depending on interferences in the sample matrix. However, these LCRs have been assigned to accommodate most minor interferences. Some of the Energy Systems LCRs are higher than the method detection limits (MDLs) listed by EPA. This is consistent with guidance from EPA; however, any data reponted below the MDLs must be supported by sound documentation. The LCRs applied by Energy Systems laboratories meet the needs of the programs they support. 
Table 10.5. Martin Marietta Energy Systems, Inc. (PORTS), environmental analysis procedures for miscellaneous materials

\begin{tabular}{|c|c|c|c|}
\hline \multirow{2}{*}{$\begin{array}{l}\text { Sample type/ } \\
\text { Parameter }\end{array}$} & \multicolumn{2}{|c|}{ Procedure } & \multirow{2}{*}{$\begin{array}{l}\text { Lowest concentration } \\
\text { reported }(\mathrm{LCR})^{b}\end{array}$} \\
\hline & $\mathrm{ES}^{a}$ & EPA & \\
\hline \multicolumn{4}{|l|}{$\begin{array}{l}\text { Radioactive Waste Materials } \\
\text { (alumina, sodium } \\
\text { fluoride, solutions) }\end{array}$} \\
\hline Chromium (total) & $2-E-30-0$ & 6010 & $0.2 / 0.03 \mathrm{mg} / \mathrm{L}$ \\
\hline Chromium (VI) & GAT 507 & & NA \\
\hline Iron (total) & $2-\mathrm{J}-212-0$ & 6010 & $0.05 / 0.05 \mathrm{mg} / \mathrm{L}$ \\
\hline Nickel (total) & & 6010 & $0.05 \mathrm{mg} / \mathrm{L}$ \\
\hline Nitrogen (ammonia) & $2-\bar{E}-32-0$ & & $0.2 \mathrm{mg} / \mathrm{L}$ \\
\hline Nitrogen (nitrate-nitrate & $2-\bar{E}-32-0$ & & $0.2 \mathrm{mg} / \mathrm{L}$ \\
\hline Technetium & $\begin{array}{l}2-G-24-4 \\
2-G-27-0\end{array}$ & & $\begin{array}{l}2 \times 10^{4} \mathrm{pCi} / \mathrm{kg} \\
300 \mathrm{pCi} / \mathrm{L}\end{array}$ \\
\hline Uranium & $\begin{array}{l}2-E-21-1 \\
2-E-24-1\end{array}$ & & $\begin{array}{l}\text { NA } \\
\text { NA }\end{array}$ \\
\hline $\begin{array}{l}\text { Uranium daughter beta } \\
{ }^{235} \mathrm{U}\end{array}$ & $\begin{array}{l}2-G-24-4 \\
2-G-29-1\end{array}$ & & $\begin{array}{l}\mathrm{NA} \\
\mathrm{NA}\end{array}$ \\
\hline Zinc & $2-\mathrm{J}-222-0$ & 6010 & $0.02 / 0.05 \mathrm{mg} / \mathrm{L}$ \\
\hline \multicolumn{4}{|l|}{$\begin{array}{l}\text { Special Annual Composites } \\
\text { (air filters, cylinder } \\
\text { cleaning solutions) }\end{array}$} \\
\hline Alpha activity & $\begin{array}{l}2-J-144-1 \\
2-G-30-2\end{array}$ & & $\begin{array}{l}2.0 \mathrm{pCi} / \mathrm{L} \\
2.0 \mathrm{pCi} / \text { filter }\end{array}$ \\
\hline Beta activity & $\begin{array}{l}2-G-27-0 \\
2-G-30-2\end{array}$ & & $\begin{array}{l}300 \mathrm{pCi} / \mathrm{L} \\
100 \mathrm{pCi} / \text { filter }\end{array}$ \\
\hline Transuranics & $2-G-21-1$ & & $2.0 p \mathrm{Ci} / \mathrm{L}$ \\
\hline Technetium & $\begin{array}{l}2-G-27-2 \\
2-G-30-2\end{array}$ & & $\begin{array}{l}300 \mathrm{pCi} / \mathrm{L} \\
100 \mathrm{pCi} / \text { filter }\end{array}$ \\
\hline Uranium & $\begin{array}{l}2-E-21-1 \\
2-E-24-1 \\
2-J-145-1\end{array}$ & & $\begin{array}{l}\text { NA } \\
\text { NA } \\
0.001 \mathrm{mg} / \mathrm{L}\end{array}$ \\
\hline \multicolumn{4}{|l|}{$\begin{array}{l}\text { Waste Management } \\
\text { Samples (EP Extracts,. } \\
\text { TCLP, organic } \\
\text { liquids, oils) }\end{array}$} \\
\hline Barium & EC-401-PORTS & $3010 / 6010$ & $0.2 \mathrm{mg} / \mathrm{L}$ \\
\hline Cadmium & EC-401-PORTS & $3010 / 6010$ & $0.05 \mathrm{mg} / \mathrm{L}$ \\
\hline Chromium & EC-401-PORTS & $3010 / 6010$ & $0.03 \mathrm{mg} / \mathrm{L}$ \\
\hline Lead & EC-401-PORTS & $3010 / 6010$ & $0.05 \mathrm{mg} / \mathrm{L}$ \\
\hline
\end{tabular}


Table 10.5 (Continued)

\begin{tabular}{lccl}
\hline \multicolumn{1}{c}{$\begin{array}{c}\text { Sample type/ } \\
\text { Parmeter }\end{array}$} & \multicolumn{2}{c}{ Procedure } & \multicolumn{1}{c}{$\begin{array}{c}\text { Lowest concentration } \\
\text { reported (LCR) }\end{array}$} \\
\cline { 2 - 3 } & ES $^{a}$ & EPA & \\
\hline Sewage Sludge & & & $1.4 \times 10^{3} \mathrm{pCi} / \mathrm{kg}$ \\
Alpha activity & $2-\mathrm{J}-144-1$ & & $2 \times 10^{4} \mathrm{pCi} / \mathrm{kg}$ \\
Beta activity & $2-\mathrm{G}-26-2$ & & $0.4 \mathrm{mg} / \mathrm{kg}$ \\
PCB (scan) & & 8080 & $0.2 \mathrm{mg} / \mathrm{kg}$ \\
Mercury & & 7471 & $1 \mathrm{mg} / \mathrm{kg}$ \\
Uraniun (Lotal) & EC-203-PORTS & & \\
\hline
\end{tabular}

aProcedures described in:

1. Works Laboratory Procedures Manual, GAT-1 15, rev. 3, Vols. I and II, Goodyear Atomic Corp., Piketon, Ohio.

2. Determination of Trace Elements in Uranium Compounds-Specification An:tyses. GAT-507, Goodyear Atomic Corp., Piketon, Ohio, 1968.

3. Hesse, P. R., A Textbook of SOIL Chemical Analysis, Chemical Publishing Co., New York, 1972.

4. Environmental Control-Analytical Procedure Manual, POEF-1192, Vol. 2, Martin Marictta Energy Systems. Portsmouth Gaseous Diffusion Plant, Piketon, Ohio.

bThe LCR may vary among specific samples, depending on interferences in the sample matrix. However, these LCRs have been assigned to accommodate most minor interferences. Some of the Energy Systems LCRs are higher than the method detection limits (MDLs) listed by EPA. This is consistent with guidance from EPA; however, any data reported below the MDLs must be supported by sound documentation. The LCRs applied by Energy Systems laboratories meet the needs of the programs they support. 
Table 10.6. DOE EMSL-LV intercomparison study resuits for PORTS-1990

\begin{tabular}{|c|c|c|c|c|c|c|}
\hline \multirow{2}{*}{$\begin{array}{l}\text { Analysis and } \\
\text { sample date }\end{array}$} & \multicolumn{2}{|c|}{ Value $(p C i / L)$} & \multirow{2}{*}{$\begin{array}{c}\text { Normalized } \\
\text { deviation }\end{array}$} & \multicolumn{3}{|c|}{ Performance evaluation ${ }^{a}$} \\
\hline & EPA & PORTS & & Acceptable & Marginal & Unacceptable \\
\hline & & & Water & & & \\
\hline $\begin{array}{l}\text { Alpha } \\
\text { January } \\
\text { May }\end{array}$ & $\begin{array}{l}12.0 \\
22.0\end{array}$ & $\begin{array}{l}13.00 \\
30.33\end{array}$ & $\begin{array}{l}0.5 \\
2.4\end{array}$ & 1 & 1 & \\
\hline $\begin{array}{l}\text { Beta } \\
\text { January } \\
\text { May }\end{array}$ & $\begin{array}{l}12.00 \\
15.00\end{array}$ & $\begin{array}{l}16.33 \\
17.00\end{array}$ & $\begin{array}{l}1.2 \\
0.7\end{array}$ & $\begin{array}{l}1 \\
1\end{array}$ & & \\
\hline $\begin{array}{r}\text { Uranium } \\
\text { March }\end{array}$ & 4.0 & 3.0 & 0.3 & 1 & & \\
\hline $\begin{array}{l}\text { Plutonium } \\
\text { August }\end{array}$ & 9.1 & 9.1 & 0.0 & 1 & & \\
\hline Total & & & & 5 & 1 & 0 \\
\hline
\end{tabular}

aperformance evaluation is tased on the deviation: acceptable $=+2$ to $-2 ;$ marginal $=$ any value between acceptable and unacceptable; unacceptable $=$ any ration outside +3 to -3 .

Table 10.7. DOE EML intercomparison study results for PORTS-1990

EML repon 535 (September 1990)

\begin{tabular}{|c|c|c|c|c|c|c|}
\hline \multirow{2}{*}{ Analysis } & \multicolumn{2}{|c|}{ Value (pCi/unit) } & \multirow{2}{*}{$\begin{array}{c}\text { Ratio } \\
\text { PORTS/EML }\end{array}$} & \multicolumn{3}{|c|}{ Performance evaluation ${ }^{a}$} \\
\hline & EML & PORTS & & Acceptable & Marginal & Unacceptable \\
\hline \multicolumn{7}{|c|}{ Air } \\
\hline${ }^{54} \mathrm{Mn}$ & 33.3 & 35.7 & 1.1 & 1 & & \\
\hline${ }^{57} \mathrm{Co}$ & 11.4 & 13.6 & 1.2 & 1 & & \\
\hline${ }^{60} \mathrm{Co}$ & 25.4 & 23.0 & 0.9 & 1 & & \\
\hline${ }^{134} \mathrm{Cs}$ & 16.3 & 18.3 & 1.2 & 1 & & \\
\hline${ }^{137} \mathrm{Cs}$ & 15.7 & 16.7 & 1.1 & 1 & & \\
\hline \multicolumn{7}{|l|}{ Total } \\
\hline Uranium $(\mu g)$ & 0.985 & 1.03 & 1.0 & 1 & & \\
\hline \multicolumn{7}{|c|}{ Soil } \\
\hline${ }^{137} \mathrm{Cs}$ & 196 & 218 & 1.1 & 1 & & \\
\hline \multicolumn{7}{|l|}{ Total } \\
\hline Uranium $\left(\mu_{0}^{\prime}\right)$ & 2.19 & 2.00 & 0.9 & 1 & & \\
\hline \multicolumn{7}{|c|}{ Vegetation } \\
\hline${ }^{137} \mathrm{Cs}$ & 18.2 & 18.0 & 1.0 & 1 & & \\
\hline Total & & & & 9 & 0 & 0 \\
\hline
\end{tabular}

aPerformance evaluation is based on the PORTS/EML ratio: acceptable $=0.8$ to $1.2 ;$ marginal $=0.5$ to 1.5 ; unacceptable = outside marginal limits. 
Table 10.8. Average performance of PORTS PET controls-1990

\begin{tabular}{|c|c|c|c|c|c|}
\hline \multirow[b]{2}{*}{ Parameter } & \multirow{2}{*}{$\begin{array}{l}\text { Average } \\
\text { percent } \\
\text { recovery }\end{array}$} & \multirow{2}{*}{$\begin{array}{c}\text { Average number } \\
\text { of } \mathrm{SDs}^{\circ} \\
\text { from the mean } \\
\text { of all participants }\end{array}$} & \multicolumn{3}{|c|}{ Performance evaluation ${ }^{b}$} \\
\hline & & & $\begin{array}{c}\text { Number } \\
\text { acceptable }\end{array}$ & $\begin{array}{l}\text { Number } \\
\text { marginal }\end{array}$ & $\begin{array}{c}\text { Number } \\
\text { unacceptable }\end{array}$ \\
\hline Biochemical oxygen demand ${ }^{c}$ & 85 & 1.04 & 21 & 1 & 0 \\
\hline Total organic carbon & 100 & 0.38 & 48 & $\mathbf{0}$ & 0 \\
\hline Ammonia nitrogen ${ }^{c}$ & 109 & 0.78 & 21 & 1 & 0 \\
\hline Nitrate nitrogen & 96 & 0.32 & 24 & 0 & 0 \\
\hline Total Kjeldahl nitrogen ${ }^{c}$ & 107 & 0.82 & 16 & 1 & 0 \\
\hline Orthophosphate as $\mathrm{P} c$ & 99 & 0.31 & 22 & 0 & 0 \\
\hline Total phosphorus ${ }^{c}$ & 100 & 0.52 & 22 & 0 & 0 \\
\hline Suspended solids & 98 & 0.60 & 24 & 0 & 0 \\
\hline Dissolved solids & 100 & 0.45 & 24 & 0 & 0 \\
\hline Oil and grease ${ }^{c}$ & 90 & 0.26 & 20 & 0 & 0 \\
\hline Alkalinity & 100 & 0.39 & 24 & 0 & 0 \\
\hline Calcium $^{c}$ & 100 & 0.59 & 22 & 1 & 0 \\
\hline Chloride & 99 & 0.36 & 24 & 0 & 0 \\
\hline Conductivity & 90 & 0.22 & 24 & 0 & 0 \\
\hline Magnesium $^{c}$ & 105 & 1.69 & 11 & 0 & 1 \\
\hline Sulfate ${ }^{c}$ & 97 & 0.35 & 22 & 0 & 0 \\
\hline Total hardness as $\mathrm{CaCO}_{3}$ & 93 & 1.48 & 22 & 1 & 1 \\
\hline $\mathrm{pH}$ & 103 & 0.54 & 24 & 0 & 0 \\
\hline Aluminum & 107 & 0.75 & 24 & 0 & 0 \\
\hline Arsenic & 103 & 0.47 & 23 & 1 & 0 \\
\hline Barium & 101 & 0.41 & 24 & 0 & 0 \\
\hline Beryllium & 102 & 0.64 & 24 & 0 & 0 \\
\hline Cadmium & 104 & 0.72 & 24 & 0 & 0 \\
\hline Chromium & 102 & 0.36 & 39 & 0 & 0 \\
\hline Cobalt & 102 & 0.49 & 6 & 0 & 0 \\
\hline Copper ${ }^{c}$ & 95 & 0.94 & 21 & 1 & 1 \\
\hline Iron & 111 & 0.86 & 23 & 0 & 1 \\
\hline Lead & 99 & 0.98 & 22 & 2 & 0 \\
\hline Manganese & 100 & 0.31 & 24 & 0 & 0 \\
\hline Mercury ${ }^{c}$ & 106 & 0.48 & 22 & 0 & 0 \\
\hline Molybdenum ${ }^{c}$ & 87 & 0.38 & 4 & 0 & 0 \\
\hline Nickel & 109 & 0.78 & 24 & 0 & 0 \\
\hline Selenium ${ }^{c}$ & 104 & 0.69 & 22 & 1 & 0 \\
\hline Silver & 103 & 0.90 & 39 & 2 & 1 \\
\hline Vanadium & 100 & 0.28 & 24 & 0 & 0 \\
\hline Zinc & 108 & 1.81 & 19 & 2 & 3 \\
\hline Residual chlorine & 92 & 0.32 & 24 & 0 & 0 \\
\hline Fluoride & 96 & 0.66 & 31 & 1 & 0 \\
\hline Total organic halides & 94 & 0.42 & 46 & 0 & 0 \\
\hline Hexavalent chromium & 100 & 0.42 & 26 & 0 & 0 \\
\hline Uranium & 108 & 1.58 & 42 & 2 & 4 \\
\hline Benzene $^{c}$ & 111 & 0.72 & 7 & 1 & 0 \\
\hline Chlorobenzene $^{c}$ & 100 & 0.56 & 10 & 0 & 0 \\
\hline 1,2-Dichlorobenzene ${ }^{c}$ & 105 & 0.58 & 4 & 0 & 0 \\
\hline 1,4-Dichlorobenzene ${ }^{c}$ & 87 & 0.43 & 2 & 0 & 0 \\
\hline Ethyl Benzene ${ }^{c}$ & 98 & 0.67 & 6 & 0 & 0 \\
\hline Toluene $^{c}$ & 99 & 0.82 & 7 & 1 & 0 \\
\hline Carbon Tetrachloride ${ }^{c}$ & 115 & 0.97 & 7 & 1 & 0 \\
\hline Chloroform ${ }^{c}$ & 100 & 0.40 & 10 & 0 & 0 \\
\hline Tetrachloroethene ${ }^{c}$ & 103 & 0.70 & 10 & 0 & 0 \\
\hline 1,1,1-Trichloroethane $e^{c}$ & 117 & 1.01 & 12 & 2 & 0 \\
\hline $1,1,2 \cdot$ Trichloroethane $^{c}$ & 96 & 0.29 & 10 & 0 & 0 \\
\hline
\end{tabular}


Table 10.8 (continued)

\begin{tabular}{|c|c|c|c|c|c|}
\hline \multirow[b]{2}{*}{ Parameter } & \multirow{2}{*}{$\begin{array}{l}\text { Average } \\
\text { percent } \\
\text { recovery }\end{array}$} & \multirow{2}{*}{$\begin{array}{l}\text { Average number } \\
\text { of SDs } \\
\text { from the mean } \\
\text { of all participants }\end{array}$} & \multicolumn{3}{|c|}{ Performance evaluation ${ }^{b}$} \\
\hline & & & $\begin{array}{c}\text { Number } \\
\text { acceptable }\end{array}$ & $\begin{array}{l}\text { Number } \\
\text { marginal }\end{array}$ & $\begin{array}{c}\text { Number } \\
\text { unacceptable }\end{array}$ \\
\hline Trichloroethene $^{c}$ & 101 & 0.58 & 2 & 0 & 0 \\
\hline 4-Chloro-3-Methyl Phenol ${ }^{c}$ & 62 & 0.65 & 4 & 0 & 0 \\
\hline 2,4-Dichlorophenolc ${ }^{c}$ & 66 & 1.00 & 4 & 0 & 0 \\
\hline 2,4-Dinitrophenol ${ }^{c}$ & 74 & 1.12 & 2 & 0 & 0 \\
\hline 4-Nitrophenol ${ }^{c}$ & 80 & 0.95 & 2 & 0 & 0 \\
\hline Pentachlorophenol $^{c}$ & 60 & 0.79 & 4 & 0 & 0 \\
\hline Phenol ${ }^{c}$ & 53 & 0.42 & 2 & 0 & 0 \\
\hline \multirow[t]{2}{*}{ Gamma-BHC ${ }^{c}$} & 98 & 0.43 & 8 & 0 & 0 \\
\hline & & & 1,105 & 22 & 12 \\
\hline
\end{tabular}

${ }^{a} \mathrm{SD}=$ standard deviation from the mean.

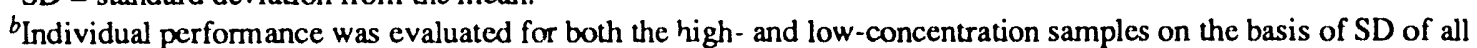
participating laboratories: acceptable = less than $1.96 \mathrm{SD}$; marginal $=1.97$ to $2.58 \mathrm{SD}$; and unacceptable $=$ greater than $2.58 \mathrm{SD}$.

"Participation in the program for the parameter indicated was limited to part of the year; therefore, fewer than 24 samples were analyzed. 
Table 10.9. EPA Performance Evaluation DMR-QA Study 010 for PORTS

\begin{tabular}{|c|c|c|c|c|c|}
\hline Analytes & $\begin{array}{l}\text { Reported } \\
\text { value }\end{array}$ & $\begin{array}{c}\text { True } \\
\text { value }^{a}\end{array}$ & $\begin{array}{c}\text { Acceptance } \\
\text { limits }\end{array}$ & $\begin{array}{l}\text { Warning } \\
\text { limits }\end{array}$ & $\begin{array}{l}\text { Performance } \\
\text { evaluation }^{b}\end{array}$ \\
\hline \multicolumn{6}{|c|}{ Trace metals $(\mu g / L)$} \\
\hline $\begin{array}{l}\text { Arsenic } \\
\text { Chromium } \\
\text { Copper } \\
\text { Iron } \\
\text { Manganese } \\
\text { Nickel } \\
\text { Zinc }\end{array}$ & $\begin{array}{l}29.7 \\
57 \\
64 \\
674 \\
210 \\
228 \\
926\end{array}$ & $\begin{array}{l}30.0 \\
50.0 \\
85.0 \\
650 \\
200 \\
200 \\
900\end{array}$ & $\begin{array}{l}20.6-37.6 \\
37.2-61.0 \\
72.9-94.5 \\
559-737 \\
178-217 \\
172-227 \\
783-1000\end{array}$ & $\begin{array}{l}22.7-35.5 \\
40.2-58.0 \\
15.4-91.8 \\
581-715 \\
183-212 \\
179-220 \\
810-976\end{array}$ & $\begin{array}{l}\text { Acceptable } \\
\text { Acceptable } \\
\text { Not acceptable } \\
\text { Acceptable } \\
\text { Acceptable } \\
\text { Not acceptable } \\
\text { Acceptable }\end{array}$ \\
\hline \multicolumn{6}{|c|}{ Miscellaneous analyses } \\
\hline $\begin{array}{l}\mathrm{pH} \text { (units) } \\
\text { Total suspended }\end{array}$ & 6.11 & 6.00 & $5.86-6.12$ & $5.89-6.09$ & Check for error \\
\hline $\begin{array}{l}\text { solids }(\mathrm{mg} / \mathrm{L}) \\
\text { Oil and grease } \\
(\mathrm{mg} / \mathrm{L})\end{array}$ & $\begin{array}{l}69.7 \\
13.4\end{array}$ & $\begin{array}{l}73.0 \\
18.0\end{array}$ & $\begin{array}{l}61.3-78.0 \\
10.6-23.2\end{array}$ & $\begin{array}{l}63.3-75.9 \\
12.2-21.7\end{array}$ & $\begin{array}{l}\text { Acceptable } \\
\text { Acceptable }\end{array}$ \\
\hline \multicolumn{6}{|c|}{ Nutrients $(m g / L)$} \\
\hline $\begin{array}{l}\text { Ammonia as nitrogen } \\
\text { Nitrate as nitrogen } \\
\text { Kjeldahl as nitrogen }\end{array}$ & $\begin{array}{l}3.6 \\
2.12 \\
19.2\end{array}$ & $\begin{array}{l}3.60 \\
2.20 \\
21.0\end{array}$ & $\begin{array}{l}2.80-4.34 \\
1.73-2.67 \\
16.1-25.1\end{array}$ & $\begin{array}{l}2.994 .16 \\
1.85-2.56 \\
17.1-24.0\end{array}$ & $\begin{array}{l}\text { Acceptable } \\
\text { Acceptable } \\
\text { Acceptable }\end{array}$ \\
\hline \multicolumn{6}{|c|}{ Demands, $(m g / L)$} \\
\hline 5-d BOD & 33.96 & 50.9 & $29.1-72.8$ & $34.5-67.4$ & Check for error \\
\hline \multicolumn{6}{|c|}{ Additional miscellaneous analyses } \\
\hline $\begin{array}{l}\text { Total residual chlorine } \\
(\mathrm{mg} / \mathrm{L})\end{array}$ & 1.40 & 1.50 & $0.896-1.82$ & $1.02-1.70$ & Acceptable \\
\hline $\mathrm{pH}$ (units) & 8.43 & 8.50 & $8.19-8.84$ & $8.27-8.76$ & Acceptable \\
\hline $\begin{array}{l}\text { Total suspended solids } \\
(\mathrm{mg} / \mathrm{L})\end{array}$ & 58.8 & 60.0 & $48.5-62.0$ & $50.2-60.3$ & Acceptable \\
\hline Oil and grease (mg/L) & 8.0 & 10.0 & $3.51-15.2$ & $4.97-13.8$ & Acceptable \\
\hline
\end{tabular}

${ }^{a}$ Based on theoretical calculations or a reference value when necessary.

$b^{b}$ The performance evaluation shown is the one reported by the EPA. For the purpose of this report, EPA acceptance limits are considered acceptable limits, the EPA notation "check for error" is indicative of a marginal value, and "not acceptable" is considered an outlier. 
Table 10.10. DOE intercomparison resuits for PORTS in the PETC coal program-1990

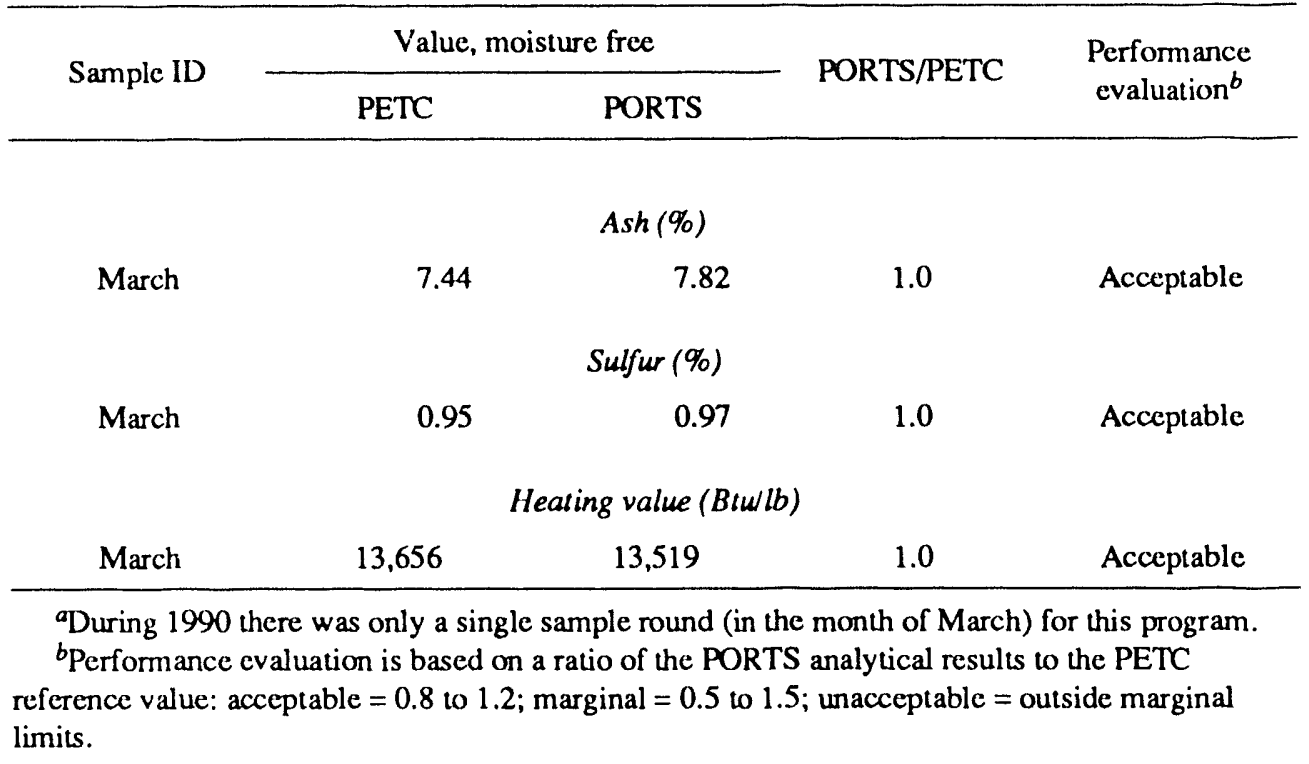


Table 10.11. NIOSH intercomparison results for PORTS in the Proficlency Analytical Testing Program (PAT)-1990

Rounds 100-103

\begin{tabular}{|c|c|c|c|c|}
\hline \multirow{2}{*}{ Analysis } & \multicolumn{2}{|c|}{ Value (mg) } & \multirow{2}{*}{$\begin{array}{c}\text { Ratio } \\
\text { PORTS/PAT }\end{array}$} & \multirow{2}{*}{$\begin{array}{l}\text { Performance } \\
\text { evaluation }^{a}\end{array}$} \\
\hline & PAT & PORTS & & \\
\hline & & Lead & & \\
\hline $3 / 13$ & $\begin{array}{l}0.0443 \\
0.0591 \\
0.0201 \\
0.0328\end{array}$ & $\begin{array}{l}0.0426 \\
0.0564 \\
0.0182 \\
0.0319\end{array}$ & $\begin{array}{l}1.0 \\
1.0 \\
0.9 \\
1.0\end{array}$ & $\begin{array}{l}\text { Acceptable } \\
\text { Acceptable } \\
\text { Acceptable } \\
\text { Acceptable }\end{array}$ \\
\hline $5 / 23$ & $\begin{array}{l}0.0241 \\
0.0419 \\
0.0575 \\
0.0361\end{array}$ & $\begin{array}{l}0.0256 \\
0.0444 \\
0.0609 \\
0.0384\end{array}$ & $\begin{array}{l}1.1 \\
1.1 \\
1.1 \\
1.1\end{array}$ & $\begin{array}{l}\text { Acceptable } \\
\text { Acceptable } \\
\text { Acceptable } \\
\text { Acceptable }\end{array}$ \\
\hline $8 / 23$ & $\begin{array}{l}0.0642 \\
0.0268 \\
0.0843 \\
0.0483\end{array}$ & $\begin{array}{l}0.0738 \\
0.0282 \\
0.0938 \\
0.0558\end{array}$ & $\begin{array}{l}1.1 \\
1.1 \\
1.1 \\
1.2\end{array}$ & $\begin{array}{l}\text { Acceptable } \\
\text { Acceptable } \\
\text { Acceptable } \\
\text { Outlier }\end{array}$ \\
\hline $11 / 20$ & $\begin{array}{l}0.0717 \\
0.0265 \\
0.0392 \\
0.0598\end{array}$ & $\begin{array}{l}0.0730 \\
0.0246 \\
0.0387 \\
0.0597\end{array}$ & $\begin{array}{l}1.0 \\
0.9 \\
1.0 \\
1.0\end{array}$ & $\begin{array}{l}\text { Acceptable } \\
\text { Acceptable } \\
\text { Acceptable } \\
\text { Acceptable }\end{array}$ \\
\hline \multicolumn{5}{|c|}{ Cadmium } \\
\hline $3 / 13$ & $\begin{array}{l}0.0089 \\
0.0118 \\
0.0157 \\
0.0099\end{array}$ & $\begin{array}{l}0.0093 \\
0.0125 \\
0.0163 \\
0.0104\end{array}$ & $\begin{array}{l}1.0 \\
1.1 \\
1.0 \\
1.1\end{array}$ & $\begin{array}{l}\text { Acceptable } \\
\text { Acceptable } \\
\text { Acceptable } \\
\text { Acceptable }\end{array}$ \\
\hline $5 / 23$ & $\begin{array}{l}0.0150 \\
0.0080 \\
0.0119 \\
0.0100\end{array}$ & $\begin{array}{l}0.0160 \\
0.0090 \\
0.0134 \\
0.0113\end{array}$ & $\begin{array}{l}1.1 \\
1.1 \\
1.1 \\
1.1\end{array}$ & $\begin{array}{l}\text { Acceptable } \\
\text { Outlier } \\
\text { Outlier } \\
\text { Acceptable }\end{array}$ \\
\hline $8 / 23$ & $\begin{array}{l}0.0090 \\
0.0117 \\
0.0192 \\
0.0119\end{array}$ & $\begin{array}{l}0.0093 \\
0.0122 \\
0.0200 \\
0.0126\end{array}$ & $\begin{array}{l}1.0 \\
1.0 \\
1.0 \\
1.1\end{array}$ & $\begin{array}{l}\text { Acceptable } \\
\text { Acceptable } \\
\text { Acceptable } \\
\text { Acceptable }\end{array}$ \\
\hline $11 / 20$ & $\begin{array}{l}0.0072 \\
0.0107 \\
0.0111 \\
0.0185\end{array}$ & $\begin{array}{l}0.0080 \\
0.0116 \\
0.0120 \\
0.0209\end{array}$ & $\begin{array}{l}1.1 \\
1.1 \\
1.1 \\
1.1\end{array}$ & $\begin{array}{l}\text { Acceptable } \\
\text { Acceptable } \\
\text { Acceptable } \\
\text { Acceptable }\end{array}$ \\
\hline \multicolumn{5}{|c|}{ Zinc } \\
\hline $3 / 13$ & $\begin{array}{l}0.1457 \\
0.1043 \\
0.0847 \\
0.1704\end{array}$ & $\begin{array}{l}0.1413 \\
0.1031 \\
0.0845 \\
0.1723\end{array}$ & $\begin{array}{l}1.0 \\
1.0 \\
1.0 \\
1.0\end{array}$ & $\begin{array}{l}\text { Acceptable } \\
\text { Acceptable } \\
\text { Acceptable } \\
\text { Acceptable }\end{array}$ \\
\hline
\end{tabular}


Table 10.11 (continued)

\begin{tabular}{|c|c|c|c|c|}
\hline \multirow{2}{*}{ Analysis } & \multicolumn{2}{|c|}{ Value (mg) } & \multirow{2}{*}{$\begin{array}{c}\text { Ratio } \\
\text { PORTS/PAT }\end{array}$} & \multirow{2}{*}{$\begin{array}{c}\text { Performance } \\
\text { evaluation }^{a}\end{array}$} \\
\hline & PAT & PORTS & & \\
\hline $5 / 23$ & $\begin{array}{l}0.2153 \\
0.1842 \\
0.1275 \\
0.1009\end{array}$ & $\begin{array}{l}0.2119 \\
0.1913 \\
0.1332 \\
0.1064\end{array}$ & $\begin{array}{l}1.0 \\
1.0 \\
1.0 \\
1.1\end{array}$ & $\begin{array}{l}\text { Acceptable } \\
\text { Acceptable } \\
\text { Acceptable } \\
\text { Acceptable }\end{array}$ \\
\hline $8 / 23$ & $\begin{array}{l}0.1071 \\
0.1297 \\
0.2185 \\
0.1751\end{array}$ & $\begin{array}{l}0.1105 \\
0.1314 \\
0.2180 \\
0.1768\end{array}$ & $\begin{array}{l}1.0 \\
1.0 \\
1.0 \\
1.0\end{array}$ & $\begin{array}{l}\text { Acceptable } \\
\text { Acceptable } \\
\text { Acceptable } \\
\text { Acceptable }\end{array}$ \\
\hline \multicolumn{5}{|c|}{ Chromium } \\
\hline $11 / 20$ & $\begin{array}{l}0.0894 \\
0.0528 \\
0.1015 \\
0.1947\end{array}$ & $\begin{array}{l}0.0944 \\
0.0556 \\
0.1092 \\
0.2050\end{array}$ & $\begin{array}{l}1.1 \\
1.1 \\
1.1 \\
1.1\end{array}$ & $\begin{array}{l}\text { Acceptable } \\
\text { Acceptable } \\
\text { Acceptable } \\
\text { Acceptable }\end{array}$ \\
\hline \multicolumn{5}{|c|}{ Silica } \\
\hline $3 / 13$ & $\begin{array}{l}0.0738 \\
0.0881 \\
0.1102 \\
0.0986\end{array}$ & $\begin{array}{l}0.0775 \\
0.0676 \\
0.1019 \\
0.1219\end{array}$ & $\begin{array}{l}1.1 \\
0.8 \\
0.9 \\
1.2\end{array}$ & $\begin{array}{l}\text { Acceptable } \\
\text { Acceptable } \\
\text { Acceptable } \\
\text { Acceptable }\end{array}$ \\
\hline $5 / 23$ & $\begin{array}{l}0.0910 \\
0.0735 \\
0.0707 \\
0.0391\end{array}$ & $\begin{array}{l}0.0803 \\
0.0584 \\
0.0558 \\
0.0321\end{array}$ & $\begin{array}{l}0.9 \\
0.8 \\
0.8 \\
0.8\end{array}$ & $\begin{array}{l}\text { Acceptable } \\
\text { Acceptable } \\
\text { Acceptable } \\
\text { Acceptable }\end{array}$ \\
\hline $8 / 23$ & $\begin{array}{l}0.0702 \\
0.0778 \\
0.0534 \\
0.0842\end{array}$ & $\begin{array}{l}0.0635 \\
0.0749 \\
0.0395 \\
0.0724\end{array}$ & $\begin{array}{l}0.9 \\
1.0 \\
0.7 \\
0.9\end{array}$ & $\begin{array}{l}\text { Acceptable } \\
\text { Acceptable } \\
\text { Acceptable } \\
\text { Acceptable }\end{array}$ \\
\hline $11 / 20$ & $\begin{array}{l}0.0978 \\
0.0381 \\
0.0937 \\
0.1206\end{array}$ & $\begin{array}{l}0.0753 \\
0.0213 \\
0.0704 \\
0.1140\end{array}$ & $\begin{array}{l}0.8 \\
0.6 \\
0.8 \\
0.9\end{array}$ & $\begin{array}{l}\text { Acceptable } \\
\text { Acceptable } \\
\text { Acceptable } \\
\text { Acceptable }\end{array}$ \\
\hline \multicolumn{5}{|c|}{ Asbestos (Fibers $/ \mathrm{mm}^{2}$ ) } \\
\hline $3 / 13$ & $\begin{array}{l}763.4 \\
503.5 \\
158.5 \\
383.3\end{array}$ & $\begin{array}{l}748.3 \\
649.7 \\
152.3 \\
423.6\end{array}$ & $\begin{array}{l}1.0 \\
1.3 \\
1.0 \\
1.1\end{array}$ & $\begin{array}{l}\text { Acceptable } \\
\text { Acceptable } \\
\text { Acceptable } \\
\text { Acceptable }\end{array}$ \\
\hline $5 / 23$ & $\begin{array}{l}217.8 \\
147.1 \\
246.8 \\
459.6\end{array}$ & $\begin{array}{l}351.3 \\
211.9 \\
401.5 \\
675.8\end{array}$ & $\begin{array}{l}1.6 \\
1.4 \\
1.6 \\
1.5\end{array}$ & $\begin{array}{l}\text { Acceptable } \\
\text { Acceptable } \\
\text { Acceptable } \\
\text { Acceptable }\end{array}$ \\
\hline $8 / 23$ & $\begin{array}{l}369.3 \\
573.2 \\
783.1 \\
224.8\end{array}$ & $\begin{array}{l}387.0 \\
592.9 \\
773.9 \\
186.6\end{array}$ & $\begin{array}{l}1.0 \\
1.0 \\
1.0 \\
0.8\end{array}$ & $\begin{array}{l}\text { Acceptable } \\
\text { Acceptable } \\
\text { Acceptable } \\
\text { Acceptable }\end{array}$ \\
\hline
\end{tabular}


Table 10.11 (continued)

\begin{tabular}{|c|c|c|c|c|}
\hline \multirow{2}{*}{ Analysis } & \multicolumn{2}{|c|}{ Value (mg) } & \multirow{2}{*}{$\begin{array}{c}\text { Ratio } \\
\text { PORTS/PAT }\end{array}$} & \multirow{2}{*}{$\begin{array}{l}\text { Performance } \\
\text { evaluation }^{a}\end{array}$} \\
\hline & PAT & PORTS & & \\
\hline $11 / 20$ & $\begin{array}{l}173.3 \\
361.6 \\
521.3 \\
554.4\end{array}$ & $\begin{array}{l}133.4 \\
509.6 \\
570.5 \\
504.7\end{array}$ & $\begin{array}{l}0.8 \\
1.4 \\
1.1 \\
0.9\end{array}$ & $\begin{array}{l}\text { Acceptable } \\
\text { Acceptable } \\
\text { Acceptable } \\
\text { Acceptable }\end{array}$ \\
\hline \multicolumn{5}{|c|}{ Solvent 1} \\
\hline $3 / 13$ & $\begin{array}{l}0.5744 \\
0.8073 \\
1.0167 \\
0.4581\end{array}$ & $\begin{array}{l}0.5750 \\
0.7840 \\
1.0100 \\
0.4440\end{array}$ & $\begin{array}{l}1.0 \\
1.0 \\
1.0 \\
1.0\end{array}$ & $\begin{array}{l}\text { Acceptable } \\
\text { Acceptable } \\
\text { Acceptable } \\
\text { Acceptable }\end{array}$ \\
\hline $5 / 23$ & $\begin{array}{l}0.7153 \\
0.8474 \\
0.4361 \\
1.0451\end{array}$ & $\begin{array}{l}0.7680 \\
0.8980 \\
0.4590 \\
1.1070\end{array}$ & $\begin{array}{l}1.1 \\
1.1 \\
1.1 \\
1.1\end{array}$ & $\begin{array}{l}\text { Acceptable } \\
\text { Acceptable } \\
\text { Acceptable } \\
\text { Acceptable }\end{array}$ \\
\hline $8 / 23$ & $\begin{array}{l}0.1909 \\
0.2445 \\
0.2894 \\
0.1477\end{array}$ & $\begin{array}{l}0.1950 \\
0.2480 \\
0.2880 \\
0.1520\end{array}$ & $\begin{array}{l}1.0 \\
1.0 \\
1.0 \\
1.0\end{array}$ & $\begin{array}{l}\text { Acceptable } \\
\text { Acceptable } \\
\text { Acceptable } \\
\text { Acceptable }\end{array}$ \\
\hline $11 / 20$ & $\begin{array}{l}1.2119 \\
0.4495 \\
0.9283 \\
0.6597\end{array}$ & $\begin{array}{l}1.1800 \\
0.4290 \\
0.9140 \\
0.6370\end{array}$ & $\begin{array}{l}1.0 \\
1.0 \\
1.0 \\
1.0\end{array}$ & $\begin{array}{l}\text { Acceptable } \\
\text { Acceptable } \\
\text { Acceptable } \\
\text { Acceptable }\end{array}$ \\
\hline \multicolumn{5}{|c|}{ Solvent 2} \\
\hline $3 / 13$ & $\begin{array}{l}0.8692 \\
0.6752 \\
0.4394 \\
1.0773\end{array}$ & $\begin{array}{l}0.8510 \\
0.6310 \\
0.4200 \\
1.0200\end{array}$ & $\begin{array}{l}1.0 \\
0.9 \\
1.0 \\
0.9\end{array}$ & $\begin{array}{l}\text { Acceptable } \\
\text { Acceptable } \\
\text { Acceptable } \\
\text { Acceptable }\end{array}$ \\
\hline $5 / 23$ & $\begin{array}{l}0.4979 \\
0.7694 \\
1.0992 \\
0.3605\end{array}$ & $\begin{array}{l}0.5230 \\
0.8100 \\
1.1560 \\
0.3740\end{array}$ & $\begin{array}{l}1.1 \\
1.1 \\
1.1 \\
1.0\end{array}$ & $\begin{array}{l}\text { Acceptable } \\
\text { Acceptable } \\
\text { Acceptable } \\
\text { Acceptable }\end{array}$ \\
\hline $8 / 23$ & $\begin{array}{l}1.0888 \\
0.8029 \\
1.2496 \\
1.5362\end{array}$ & $\begin{array}{l}1.1930 \\
0.8730 \\
1.3580 \\
1.7070\end{array}$ & $\begin{array}{l}1.1 \\
1.1 \\
1.1 \\
1.1\end{array}$ & $\begin{array}{l}\text { Acceptable } \\
\text { Acceptable } \\
\text { Acceptable } \\
\text { Acceptable }\end{array}$ \\
\hline $11 / 20$ & $\begin{array}{l}0.6528 \\
0.9434 \\
1.1060 \\
0.7943\end{array}$ & $\begin{array}{l}0.6530 \\
0.9490 \\
1.1200 \\
0.7820\end{array}$ & $\begin{array}{l}1.0 \\
1.0 \\
1.0 \\
1.0\end{array}$ & $\begin{array}{l}\text { Acceptable } \\
\text { Acceptable } \\
\text { Acceptable } \\
\text { Acceptable }\end{array}$ \\
\hline \multicolumn{5}{|c|}{ Solvent 3} \\
\hline $3 / 13$ & $\begin{array}{l}0.8394 \\
0.9611 \\
0.6908 \\
0.7723\end{array}$ & $\begin{array}{l}0.8350 \\
0.9280 \\
0.6830 \\
0.7510\end{array}$ & $\begin{array}{l}1.0 \\
1.0 \\
1.0 \\
1.0\end{array}$ & $\begin{array}{l}\text { Acceptable } \\
\text { Acceptable } \\
\text { Acceptable } \\
\text { Acceptable }\end{array}$ \\
\hline
\end{tabular}


Table 10.11 (continued)

\begin{tabular}{|c|c|c|c|c|}
\hline \multirow{2}{*}{ Analysis } & \multicolumn{2}{|c|}{ Value (mg) } & \multirow{2}{*}{$\begin{array}{c}\text { Ratio } \\
\text { PORTS/PAT }\end{array}$} & \multirow{2}{*}{$\begin{array}{l}\text { Performance } \\
\text { evaluation }^{a}\end{array}$} \\
\hline & PAT & PORTS & & \\
\hline \multirow[t]{4}{*}{$5 / 23$} & 0.8619 & 0.9060 & 1.1 & Acceptable \\
\hline & 0.4305 & 0.4430 & 1.0 & Acceptable \\
\hline & 0.6061 & 0.6220 & 1.0 & Acceptable \\
\hline & 0.6869 & 0.7100 & 1.0 & Acceptable \\
\hline \multirow[t]{4}{*}{$8 / 23$} & 1.5987 & 1.6180 & 1.0 & Acceptable \\
\hline & 0.9020 & 0.9130 & 1.0 & Acceptable \\
\hline & 1.1526 & 1.1560 & 1.0 & Acceptable \\
\hline & 1.3808 & 1.4210 & 1.0 & Acceptable \\
\hline \multirow[t]{4}{*}{$11 / 20$} & 0.8790 & 0.8820 & 1.0 & Acceptable \\
\hline & 0.5839 & 0.5860 & 1.0 & Acceptable \\
\hline & 0.9533 & 0.9620 & 1.0 & Acceptable \\
\hline & 1.1533 & 1.1450 & 1.0 & Acceptable \\
\hline
\end{tabular}

${ }^{a}$ Portsmouth Laboratory was rated Proficient for all analyses in Rounds $100-103$ for 1990 . 


\section{REFERENCES}

American National Standards Institute (ANSI) 1975. Performance Testing and Procedural Specifications for Thermoluminescent Dosimetry (Environmental Applications).

Begovich, C. L. et al. August 1981. DARTAB: A Program to Combine Airborne Radionuclide Environmental Exposure Data with Dosimetric and Health Effects Data To Generate Tabulations of Predicted Health Impacts, ORNL-5692, Union Carbide Corp. Nuclear Div., Oak Ridge Natl. Lab.

Dunning, D. E. Jr., Leggett, R. W., and Yalcintas, M. G. 1980. A Combined Methodology for Estimating Dose Rates and Health Effects from Radioactive Pollutants, ORNL/TM-7105, Union Carbide Corp. Nuclear Div., Oak Ridge Natl. Lab.

Geraghty and Miller, Inc. May 1989. Quadrant I Description of Current Conditions, Dublin, Ohio.

Geraghty and Miller, Inc. Junc 1989. Groundwater Quality Assessment of Four RCRA Units, Dublin, Ohio.

Hoffman, F. O., et al. 1984. Preliminary Screening of Contaminants in Sediments, ORNL/TM-9370, Union Carbide Corp. Nuclear Div., Oak Ridge Natl. Lab.

International Commission on Radiological Protection (ICRP) 1977. Annals of the ICRP I, ICRP Publication 26, Pergamon, Oxford, N.Y.

International Commission on Radiological Protection (ICRP) 1978. Publication 3C, Pergamon, Oxford, N.Y.

Keller, K. K. Apr. 1989. Off-site Residential Drinking Water Quality Monitoring Plan, Martin Marietta Energy Systems, Portsmouth Gaseous Diffusion Plant.
Kimbrough, C. W., Long, L. W., and McMahon, L. W., eds. Sept. 1, 1988. Environmental Surveillance Procedures Quality Control Program, ESH/Sub/87-21706/1, Advanced Sciences, Oak Ridge, Tenn.

Law Engineering 1978. Gas Centrifuge Enrichment Plant-Geotechnical Investigation, Vols. 1-4, Marietta, Ga.

Mitchell, M. E. Apr. 18, 1990. Environmental and Safety Activities, Martin Marietta Energy Systems, Inc., Oak Ridge Gaseous Diffusion Plant, Oak Ridge, Tenn., leuter to P. J. Gross, Environmental Protection Division, Oak Ridge Operations Office, Oak Ridge, Tenn., "Annual Radionuclide Air Emissions Report for the Oak Ridge Reservation (ORR), Paducah Gaseous Diffusion Plant (PGDP), and the Portsmouth Gaseous Diffusion Plant (PORTS) for CY 1989-40 CFR 61.94(c)."

Moore, R. E. et al. 1979. AIRDOS-EPA: A Computerized Methodology for Estimating Environmental Concentrations and Dose to Man from Airborne Releases of Radionuclides, EPA-520/1-79-009.

Munro, N. B., and Travis, C. C. 1986. "Drinking-Water Standards," Environ. Sci. Technol. 20(8), 768-69.

Portsmouth Gaseous Diffusion Plant (PORTS) December 1988. Biodenitrification Optimization Report, POEF-P-128.

Portsmouth Gaseous Diffusion Plant (PORTS) March 1990. Biodenitrification Optimization Report.

Sittig, M. 1980. Priority Toxic Pollutants: Health Impact and Allowable Limits, Noyes Data Corp., Parkridge, N.J., p. 370. 
Sjoreen, A. L. and Miller, C. W. 1984. PREPAR 4 User-Friendly Preprocessor To Create AIRDOS-EPA Input Data Sets, ORNL-5952, Martin Marietta Energy Systems, Oak Ridge Natl. Lab.

U.S. Department of Energy (DOE). Doe Manual, DOE Order 5400.1 .

U.S. Department of Energy (DOE). Doe Manual, DOE Order 5480.2.

U.S. Department of Energy (DOE). Doe Manual, DOE Order 5632.1.

U.S. Department of Energy (DOİ). Doe Manual, DOE Order 5820.2A.

U.S. Environmental Protection Agency (EPA) November 1986. Test Metho's for E'valuating Solid Wastes, Rev. 23, $S W-846$.
U.S. Envirenmental Protection Agency (EPA) 1986. Superfund Public Health Evaluation Manual, EPA/540/1-86/060, Office of Emergency and Remedial Response.

U.S. Environmental Protection Agency (EPA) 1988. Integrated Risk Information System (IRIS) Data Base.

U.S. Environmental Protection Agency (FPA) 1989. Risk Assessment Guidance for Superfund: Human Health Evaluation Manual, Part A (Interin Final).

U.S. Environmental Protection Agency (EPA) 1991. Integrated Risk Information System (IRIS) Data Base.

U.S. Geological Survey (USGS) 1986. Water Resource Data for Ohio. 


\section{Appendix}

\section{PORTSMOUTH GASEOUS DIFFUSION PLANT CHEMICAL RELEASE DATA}

In addition to indicating the concentrations of various chemicals present in the environment near DOE facilities, in recent years, the annual environmental reports have contained an estimate of the quantities of certain chemicals being emitted to the environment. This appendix contains an expanded list of chemicals with additional information regarding the types of releases, the estimated quantities released, the major processes contributing to the releases, and a bricf description of the basis of estimates for calendar year (CY) 1990. Radiological chemical releasis for CY 1990 are not included in this appendix; they are reported in the applicable sections in this report.

Three categories of chemical releases at each Portsmouth Gaseous Diffusion Plant (PORTS) facility are reported in this appendix: (1) SARA 313, (2) Other large inventory chemicals, and (3) Steam plant emissions. The SARA 313 chemicals are summarized from information currently being compiled for the SAR.A Title III, Section 313 report, required by the Superfund Amendments and Reauthorization Act of 1986 (SARA). This report is submitted on July 1 of each year for the previous calendar year and contains chemicals on the Environmental Protection Agency's (EPA's) toxic substance list. Currently, 310 specific chemicals and 20 chemical categories must be reviewed and possibly reported under SARA Sect. 313. If any of these chemicals were manufactured in excess of $25,000 \mathrm{lb}$, processed in excess of $25,000 \mathrm{lb}$, or "otherwise used" in excess of $10,000 \mathrm{lb}$ at a facility during CY 1990, the chemical must be reported. In many instances, the estimate of quantities released was obtained via material balance calcuiations, monitoring data, or engineering calculations. In some cases, no quantitative monitoring data, inventory estimates, or emission factors were readily available, and release estimates were based on "best engineering judgement." "Best engineering judgement" was the principal method used to derive "Quantity released." Information obtained from air permits, rate of operation, quantities used, and known treatment efficiencies were used to estimate quantities released into the environment. Typically, assumptions based on "best engineering judgement" were required in order to perform the calculations when all variables were not known. Considerable manpower was expended reviewing chemical inventory information and estimating the quantities released to the environment.

The second category of chemicals reported in this appendix is "Other large inventory chemicals." This listing is included to provide additional chemical information not reportable under SARA 313. Note that this is not a complete listing of all chemicals that may have been released at the site. This list was developed to better inform the reader of the additional chemicals (those that may be of interest to the general public) used and released at PORTS.

The third category, "Steam plant emissions," is release estimates of certain chemicals from the coal-fired steam plants.

The following table summarizes the chemical release information for PORTS. 
Portsmouth Gaseous Diffusion Plant 1990 chemical release information

\begin{tabular}{|c|c|c|c|c|}
\hline Chemical name & $\begin{array}{l}\text { Type of } \\
\text { environmental } \\
\text { release }\end{array}$ & $\begin{array}{l}\text { Release } \\
\text { quantity } \\
(\mathrm{lb} / \mathrm{kg})\end{array}$ & Major release sources & $\begin{array}{l}\text { Basis of } \\
\text { estimate }\end{array}$ \\
\hline \multicolumn{5}{|c|}{$S A R A 313$} \\
\hline \multirow[t]{6}{*}{ Chlorine } & Water: Scioto River & $110 / 50$ & Sewage treatment facility & Monitoring data \\
\hline & Little Beaver Creek & $52 / 24$ & Cooling systems & Monitoring data \\
\hline & Big Run Croek & $0 / 0$ & Cooling systems & Monitoring data \\
\hline & Air: stack & $170,000 / 77,000$ & $\begin{array}{l}\text { Recirculating cooling water system/ } \\
\text { sewage treatment }\end{array}$ & Other ${ }^{a}$ \\
\hline & Air: fugitive & $11,000 / 5,000$ & Non-contact cooling water & Other ${ }^{a}$ \\
\hline & Land: other & $1 / 0.5$ & Spill-X-605G water line & Other ${ }^{a}$ \\
\hline \multirow[t]{5}{*}{ Chromium } & Air: stack & $2,800 / 1,300$ & Recirculating cooling water system & Other ${ }^{a}$ \\
\hline & Water: Scioto River & $1,500 / 680$ & Recirculating cooling water system & Monitoring data \\
\hline & Little Beaver Creck & $0 / 0$ & Spill-recirculating heating water & Other ${ }^{a}$ \\
\hline & Big Run Creek & $0 / 0$ & Spill-recirculating heating water & Other ${ }^{a}$ \\
\hline & Land: other & $0 / 0$ & Spill-recirculating cooling water & Other ${ }^{a}$ \\
\hline \multirow[t]{4}{*}{ Freon 113} & Air: fugitive & $20,000 / 9,100$ & Miscellaneous equipment cleaning & Other ${ }^{a}$ \\
\hline & Water: Scioto River & 0,0 & Miscellaneous equipment cleaning & Other ${ }^{a}$ \\
\hline & Land: other & $0 / 0$ & Not applicable & Othere \\
\hline & Offsite transfer & $1,500 / 680$ & Miscellancous equipment cleaning & Monitoring data \\
\hline \multirow[t]{5}{*}{ Methanol } & Air: fugitive & $13,000 / 5,900$ & Biodenitrification facility & Other ${ }^{a}$ \\
\hline & Air: stack & $110 / 50$ & Biodenitrification facility & Emission factors \\
\hline & Water: Scioto River & $0 / 0$ & Biodenitrification facility & Other ${ }^{a}$ \\
\hline & Land: other & $0 / 0$ & Not applicable & Other ${ }^{2}$ \\
\hline & Offsite transfer & $22 / 10$ & Biodenitrification facility & Monitoring data \\
\hline \multirow{2}{*}{ Nitric acid } & Water: Scioto River & $0 / 0$ & Miscellaneous equipment cleaning & Other $^{a}$ \\
\hline & Land: other & $2 / 4$ & Spills-miscellancous & Other ${ }^{a}$ \\
\hline \multirow[t]{2}{*}{ Phosphoric acid } & Water: Scioto River & $0 / 0$ & $\begin{array}{l}\text { Biodentrification facility/X-616 liquid } \\
\text { effluent treatment facility }\end{array}$ & Other ${ }^{a}$ \\
\hline & Land: other & $0 / 0$ & Not applicable & Othere \\
\hline \multirow[t]{2}{*}{$\begin{array}{l}\text { Polychlorinated } \\
\text { biphenyls }\end{array}$} & Land: other & $0 / 0$ & Spills-miscellancous & Other ${ }^{a}$ \\
\hline & Offsite transfer & $26 / 12$ & Electrical maintenance activities & Monitoring data \\
\hline Sulfuric acid & Water: S. holding pond & $2,700 / 1,200$ & $\begin{array}{l}\text { Spill-Hydrogen zeolite regeneration } \\
\text { steam plant water softening unit }\end{array}$ & Othera \\
\hline \multirow{4}{*}{ 1,1,1-Trichloroethane } & Land: other & $0 / 0$ & Spill-miscellaneous & Other ${ }^{a}$ \\
\hline & Air: fugitive & $9,800 / 4,500$ & Miscellaneous equipment cleaning & Other ${ }^{a}$ \\
\hline & Land: other & $0 / 0$ & Not applicable & Othere \\
\hline & Offsite transfer & $3,700 / 1,700$ & Maintenance activities & Monitoring data \\
\hline \multicolumn{5}{|c|}{ Other large inventory chemicals } \\
\hline Zinc & Water: Scioto River & $360 / 160$ & Water treatment & Monitoring data \\
\hline & Little Beaver Creek & $680 / 310$ & Water treatment & Monitoring data \\
\hline & Big Run Creek & $110 / 50$ & Water treatment & Monitoring data \\
\hline & Unnamed Tributary \#1 & $76 / 35$ & Water treatment & Monitoring data \\
\hline & Unnamed Tributary \#2 & $37 / 17$ & Water treatment & Monitoring data \\
\hline & Land: other & $0 / 0$ & Not applicable & Othere \\
\hline Freon 114 & Air: fugitive & $500,000 / 230,000$ & Air conditioning systems & Othera \\
\hline Hydrogen fluoride & Air: stack & $14,000 / 6,400$ & Production vents & Monitoring data \\
\hline \multicolumn{5}{|c|}{ Steam plant } \\
\hline Sulfur dioxide & Air: stack & $5,400,000 / 2,400,000$ & Steam plant emissions & Other ${ }^{b}$ \\
\hline $\mathrm{NO}_{\mathrm{x}}$ & Air: stack & $610,000 / 280,000$ & Steam plant emissions & Emission factors ${ }^{c}$ \\
\hline $\mathrm{CO}$ & Air: stack & $220,000 / 99,000$ & Steam plant emissions & Emission factors ${ }^{c}$ \\
\hline Particulates & Air: stack & $50,000 / 23,000$ & Steam plant emissions & Otherd \\
\hline
\end{tabular}

${ }^{a}$ Based on best engineering judgement.

${ }^{b}$ Based on coal analysis.

'Based on AP-42 emission factors.

${ }^{d} \mathrm{Based}$ on coal analysis and demonstrated performance of electrostatic precipitators.

No spills occurred. 


\section{INTERNAL DISTRIBUTION}

\author{
1. F. D. Adams \\ 2. A. D. Arms \\ 3. D. L. Ashburn \\ 4. T. L. Ashwood \\ 5. L. D. Bates \\ 6-26. R. E. Blake \\ 27. A. K. Bracknell \\ 28. K. L. Brady \\ 29. T. R. Butz \\ 30-32. W. W. Chance \\ 33. R. B. Clapp \\ 34. R. J. Cloutier \\ 35. D. M. Counce \\ 36. G. D. Del Cul \\ 37. R. J. Devol \\ 38. M. S. Dill \\ 39. T. O. Early \\ 40. R. A. Evans \\ 41. J. M. Forstrom \\ 42. M. W. Francis \\ 43. C. G. Giltner \\ 44. S. T. Goodpasture \\ 45. G. Goslow \\ 46-95. R. L. Grant \\ 96. L. E. Hall \\ 97. J. A. Hedges \\ 98. S. G. Hildebrand \\ 99. C. C. Hill \\ 100. F. O. Hoffman \\ 101. T. G. Jett \\ 102. C. G. Jones \\ 103. W. A. Kelly \\ 104. R. H. Ketelle \\ 105. C. W. Kimbrough \\ 106. F. C. Kornegay \\ 107. E. H. Krieg \\ 108. P. Y. Lu \\ 109. A. P. Malinauskas
}

110. W. D. Malis

111. L. W. McMahon

112. L. J. Mezga

113. M. E. Mitchell

114. R. W. Morrow

i15. J. B. Murphy

116. T. J. Newsom

117. F. R. O'Donnell

118. G. V. Pierce

119. S. Polston

120. H. Pulley

121-125. J. G. Rogers

126. R. T. Roseberry

127. R. H. Ross

128. G. W. Rymer

129. C. W. Sheward

130. J. E. Shoemaker

131. S. P. N. Singh

132. E. L. Smith, Jr.

133. G. W. Snyder

134. L. E. Stokes

135. S. H. Stow

136. D. W. Swindle

137. M. F. Tardiff

138. F. G. Taylor, Jr.

139. L. D. Taylor

140. T. Thomas

141. J. H. Turner

142. J. W. Turner

143. B. L. Valentine

144. L. D. Voorhees

145. J. S. Wassom

146. D. A. Waters

147. C. W. Weber

148-197. D. C. West

198. B. Wilkes

199. J. K. Williams

200. W. R. Williams 


\author{
201. A. R. Wilson \\ 202. S. W. Wohlfort \\ 203. Central Research Library \\ 204. ESD Library \\ 205-206 ORNL Laboratory Records \\ 207. ORNL Laboratory Records - RC
}

208. ORNL Patent Section

209. ORNL Y-12 Technical Library

210. PGDP Library

211. PORTS Library

212. Records Management

213. ORGDP Library

\section{EXTERNAI، DISTRIBUTION}

214. Assistant Manager for Energy Research and Development, U.S. Department of Energy/Oak Ridge Operations, P.O. Box E, Oak Ridge, TN 37631.

215-226. Office of Scientific and Technical Information.

227-400. This report is distributed widely by the Department of Energy's Oak Ridge Operations Office to local, state, and federal government agencies, the Congress, the public, and the news media. 

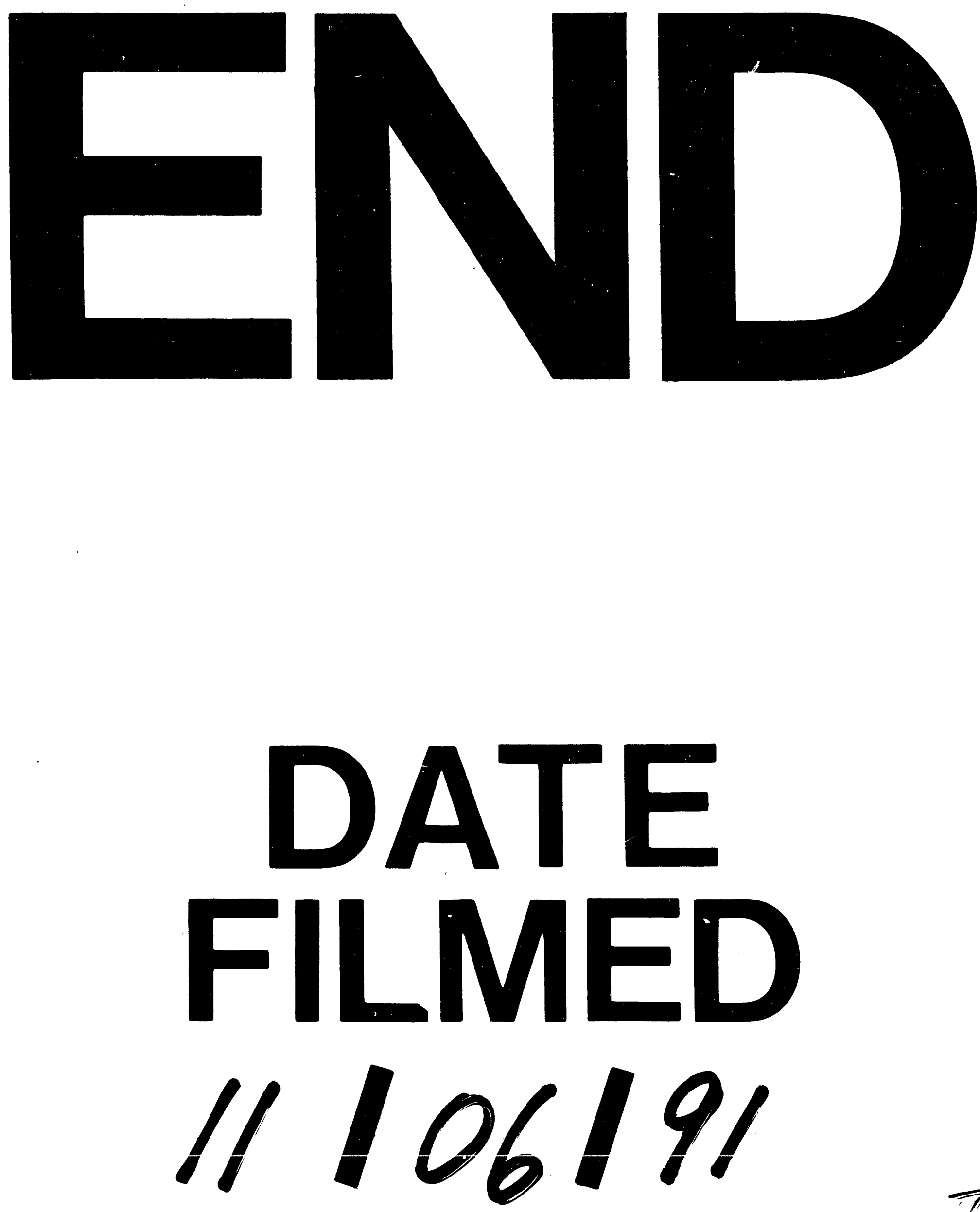

I 
